Portland State University

PDXScholar

Winter 4-3-2017

\title{
Technology Assessment Model of Developing Geothermal Energy Resources for Supporting Electrical System: the Case for Oregon
}

Ahmed Shehab Alshareef

Portland State University

Follow this and additional works at: https://pdxscholar.library.pdx.edu/open_access_etds

Part of the Engineering Commons

Let us know how access to this document benefits you.

Recommended Citation

Alshareef, Ahmed Shehab, "Technology Assessment Model of Developing Geothermal Energy Resources for Supporting Electrical System: the Case for Oregon" (2017). Dissertations and Theses. Paper 3515. https://doi.org/10.15760/etd.5399

This Thesis is brought to you for free and open access. It has been accepted for inclusion in Dissertations and Theses by an authorized administrator of PDXScholar. Please contact us if we can make this document more accessible: pdxscholar@pdx.edu. 
Technology Assessment Model of Developing Geothermal Energy Resources for Supporting Electrical System: The Case for Oregon

by

Ahmed Shehab Alshareef

A thesis submitted in partial fulfillment of the requirements for the degree of

\section{Master of Science}

in

Engineering and Technology Management

Thesis Committee:

Tugrul U. Daim, Chair

Jisun Kim

Loren Lutzenhiser

Portland State University

2017 


\begin{abstract}
The demand for energy is increasing worldwide. All applications contributed to increase the demand of all energy industry, and therefore the effect on the environment and the rise in pollution increased significantly. This is considered a large problem, and researchers focused their research on renewable energy for reducing the cost of energy in the future. Geothermal energy has significant impact as a source of electricity generation since it will not harm the environment. There are more than twenty countries that benefit from geothermal plants, which generate more than 6000 megawatts .Three alternatives of geothermal energy technology (GHP, Direct use of Geothermal Heat, and Geothermal Electricity) can be used for supporting electrical systems in Oregon. At the same time, the success of using the geothermal energy alternatives in Oregon relies on different goals for achieving the best geothermal development. Oregon has been ranked third in the potential use of geothermal energy after Nevada and California.
\end{abstract}

The objective from the research study was to develop an assessment model framework that can be used for supporting cost effective renewable energy in Oregon by the development of geothermal energy sources. This research of study was done by using the Hierarchical Decision Model (HDM) and consisted of four levels: Mission, objectives, goals, and alternative. Criteria used in this research study are based on five objectives to know what are the most important factors in the decision-making process. These objectives are: social, environmental, economical, technical, and political. The decision model connected objectives, goals, and alternative for obtaining the accurate 
decision. HDM used for this purpose to analyze the result of data collected from experts. Seven experts who had experience in the geothermal field participated in this research study, and they gave their judgment in the questionnaire survey link by using pair-wise comparison method.

The outcome analysis of the results showed that in terms of objectives that Minimizing Environmental Impact was rated at the highest value at 0.26 with respect to the mission. Within the category of Minimizing Environmental Impact, Seismic Activity and GHG Emissions had higher values. The results show that "Geothermal Electricity", with a rating of $43 \%$, was ranked as the most important alternative with respect to mission, objectives, and goals. "Direct Use of Geothermal Heat" was ranked as the second most important alternative with $31 \%$. The results of this research study were discussed with the experts to get their feedback, and learn from them what requirements are necessary for improvement in the geotechnical energy sector for future research. The experts agreed that this methodology is a good approach to help reach the right decision since this methodology (HDM) divides the problem into small sets, which will make the decision process easier. 


\section{DEDICATION}

To my dear parents, Shehab and Kareema,

who supported me in my study

and encouraged me to obtain my degree

and

to my precious wife Sarah

for her help and encouragement 


\section{ACKNOWLEDGMENTS}

First I want to thank Dr. Tugrul U. Daim, my advisor and my committee chair, for his valuable help and support from the beginning of selecting the idea and throughout all my study, and his encouragement to overcome all obstacles during the research. His knowledge and feedback made my research stronger, and he provided useful critiques of my work.

I would like to express my deep gratitude to Dr. Loren Lutzenhiser for his feedback and for supporting my idea and making it stronger by opening my eyes to its weaknesses. His experience put me on the right track. I would also like to thank Dr. Jisun Kim for his motivation and valuable help to achieve excellent work.

I would also like to extend my thanks to Dr. Daim's group of Ph.D. students. I gained a lot of knowledge and experience from them, and I hope the best for them in their research. Finally, I would like to acknowledge all faculty members in Engineering and Technology Management Department for guiding me through all the courses I took to obtain my Master's Degree. 


\section{Table of Contents}

ABSTRACT

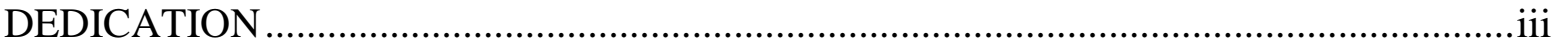

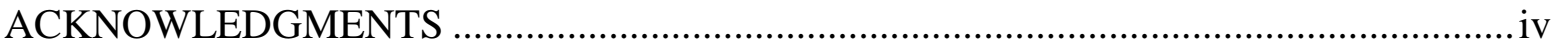

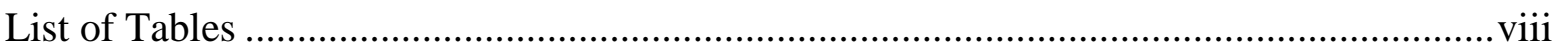

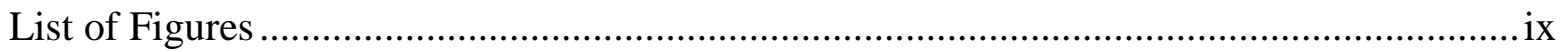

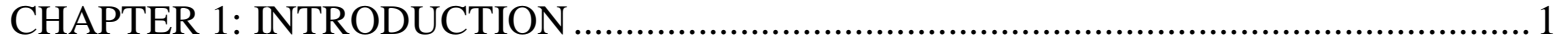

1.1 Background of the Problem............................................................................. 5

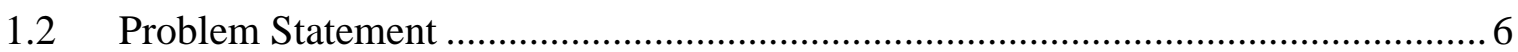

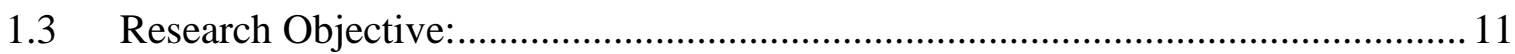

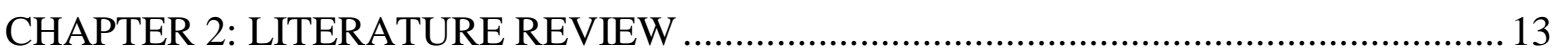

2.1 Decision Making in Energy Planning ............................................................. 13

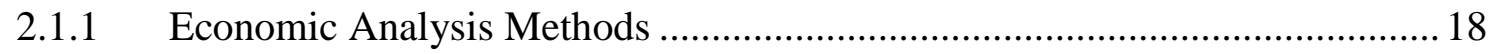

2.1.2 Decision Analysis Method .......................................................................... 23

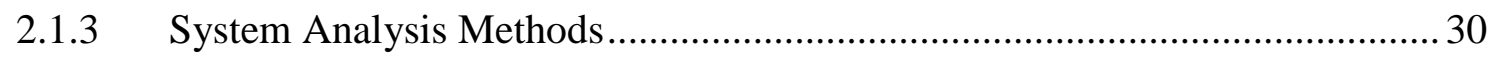

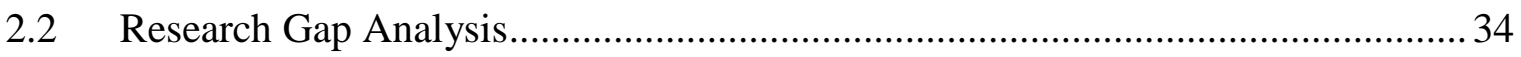

CHAPTER 3: RESEARCH APPLICATION BACKGROUND ..................................... 38

3.1 Importance of Geothermal Energy in Oregon ................................................... 38

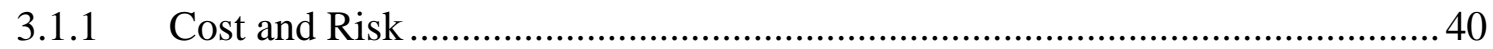

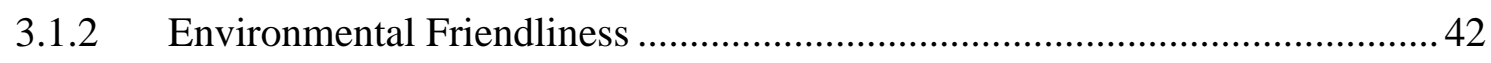

3.1.3 Increasing and Changing Electricity Demand ....................................... 45

3.1.4 Constant Prices Over the Long Term....................................................... 47

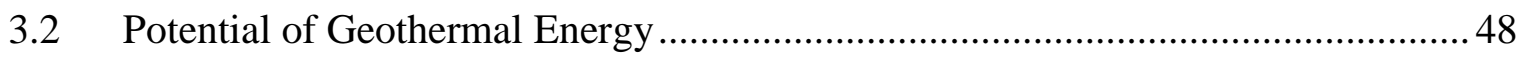

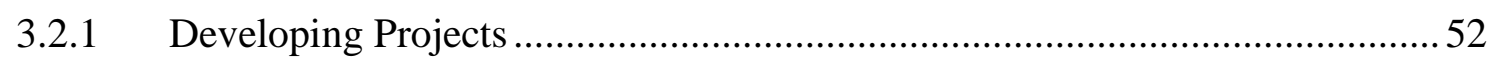

3.2.2 Global Technology and Manufacturing Development ................................. 54

CHAPTER 4: RESEARCH APPROACH AND METHODOLOGY ................................57

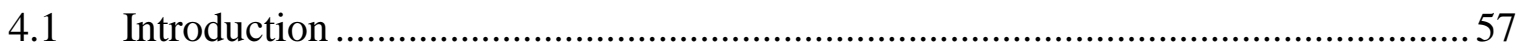

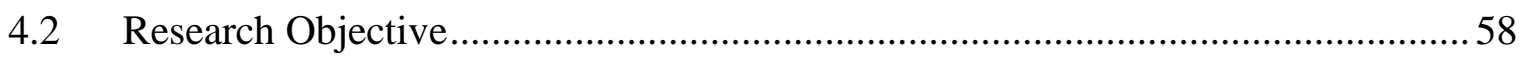

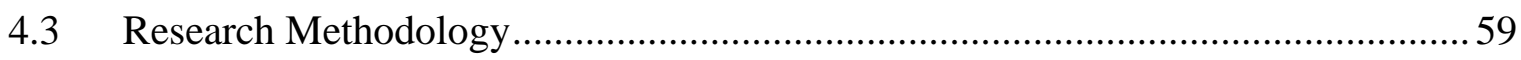

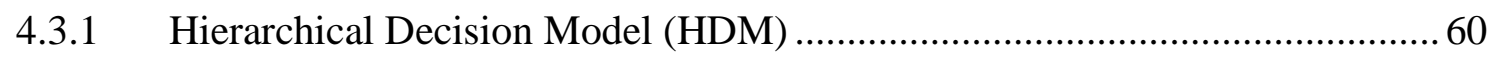

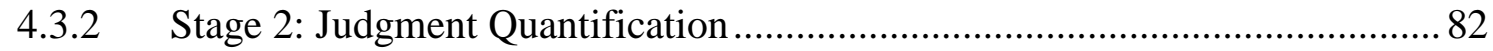




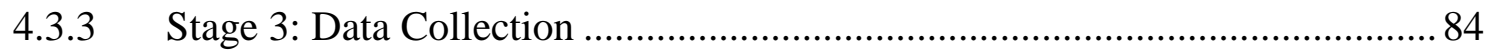

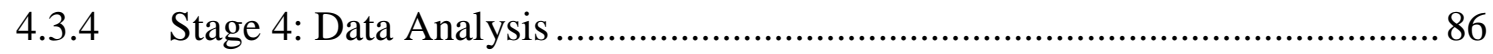

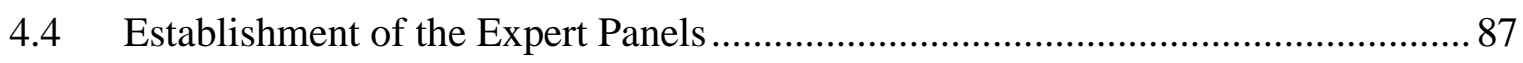

4.5 Pairwise Comparisons ................................................................................. 90

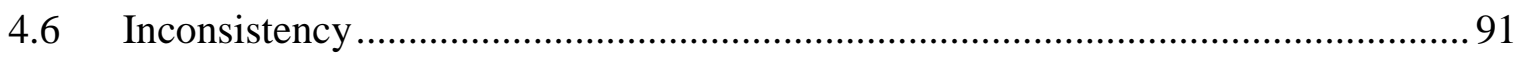

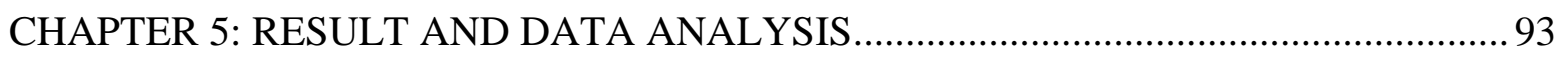

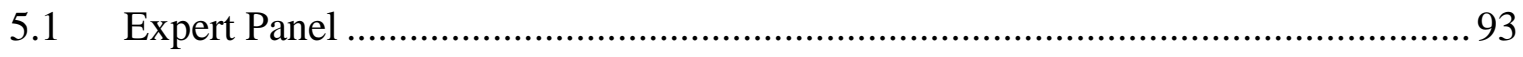

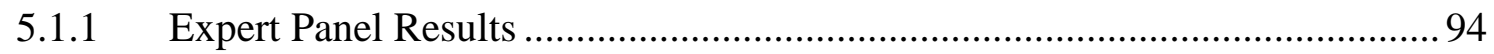

5.1.2 Analysis of Expert Panel Results .................................................................. 95

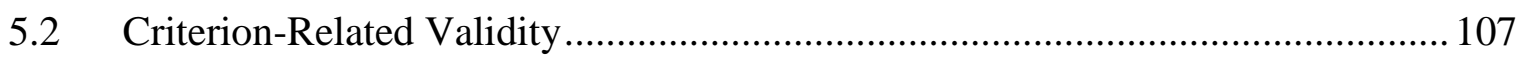

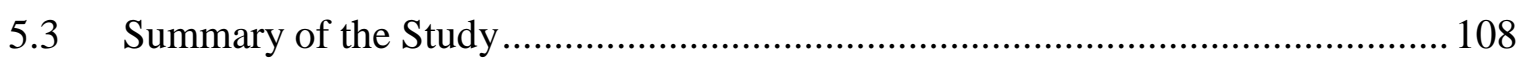

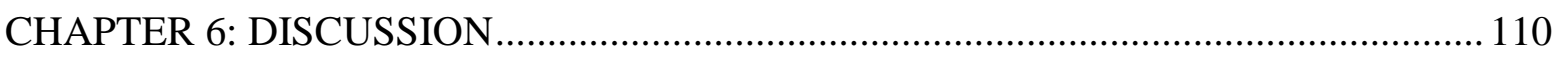

6.1 Result Analysis .......................................................................................... 110

6.1.1 Evaluation of the Objectives .................................................................... 110

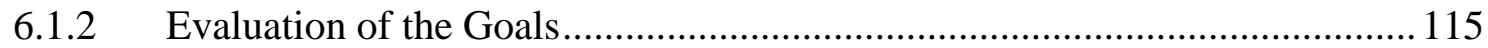

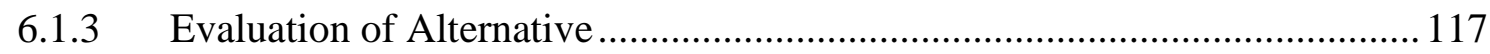

6.2 Challenges Accompanying with Geothermal Energy Projects .............................. 119

6.3 Opportunity for Successful Geothermal Energy Projects in the Future................. 121 CHAPTER 7: RESEARCH SCOPE, ASSUMPTIONS AND LIMITATIONS, EXPECTED CONTRIBUTIONS, FUTURE RESEARCH ……..................................... 123

7.1 Assumptions and Limitations of the Research Model ........................................... 123

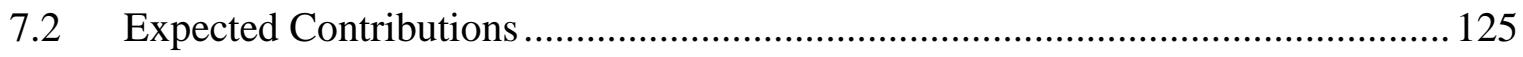

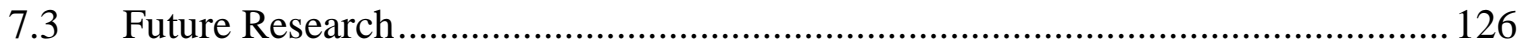

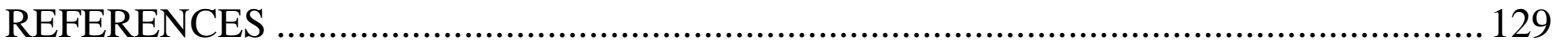

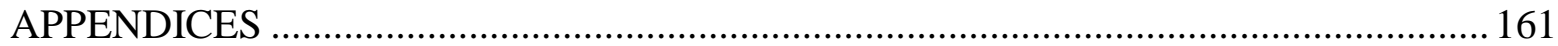

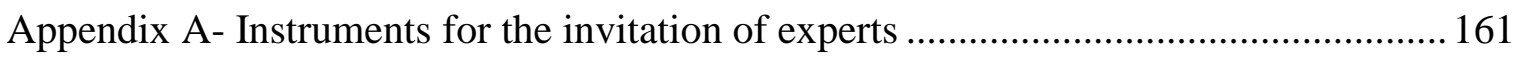

Appendix A1- The invitation of experts for participation in my M.S Thesis research161

Appendix A2-Informed Consent Form...................................................................... 163

Appendix A3- Content Web Survey........................................................................ 165

Appendix A4-Content Questionnaire Survey ............................................................. 166

Appendix A5-Content instructions and explanation of nodes....................................... 177 
Appendix B-Judgment Quantifications

Appendix B1- Judgment quantification for the objectives level with respect to the mission. 187

Appendix B2- Judgment quantification for the goals level with respect to objectives.188

Appendix B3- Judgment quantification for the alternatives level with respect to goals191

Appendix C- Calculations (Overall weight)............................................................. 196

Appendix D- Objectives weight for different characteristics of experts......................... 197 


\section{List of Tables}

Table 1: MCDM Shows More Active than SODM

Table 2: Methods Used in Energy Planning with Respect to Economic Analysis from the

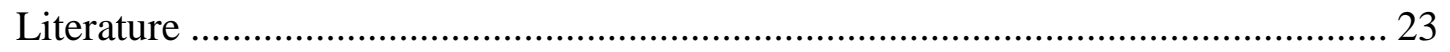

Table 3: Decision Analysis Used in Energy Planning from the Literature...................... 30

Table 4 : System Analysis Used in Energy Planning from the Literature ....................... 34

Table 5: Key Research Area and Finding in the Literature .......................................... 34

Table 6: Evaluation of Geothermal Energy Resource from the Literature Review .......... 62

Table 7: Judgment Quantification Methods in the Research Model............................... 84

Table 8: Inconsistency Analysis Method for Research Model ...................................... 87

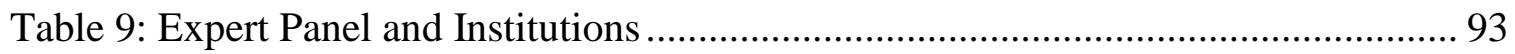

Table 10: Individual Expert Judgment for Each Alternative .......................................... 95

Table 11: Importance of Objectives from Different Characteristics of the Experts ......... 97

Table 12: Identifying the Important Objectives Made by the Experts............................. 99

Table 13: Identifying the Important Goals Chosen by the Experts .............................. 100

Table 14: Importance of Goals from Different Characteristics of the Experts ............... 102

Table 15: The Most Important Features for Geothermal Energy Alternatives that Were

Chosen by the Experts .................................................................................... 103

Table 16: Different Characteristics of Experts for Geothermal Energy Alternatives..... 106 


\section{List of Figures}

Figure 1: Decision Analysis Methods with Branches................................................... 14

Figure 2: Research Gap, Goals, and Research Question ............................................... 37

Figure 3 : Levelized Cost of Selection Technologies ………...................................... 42

Figure 4: Using Types of Energy in the Electric Power ................................................ 44

Figure 5: Impact of Geothermal Energy Resource on the Environment .......................... 44

Figure 6: International Geothermal Power Nameplate Capacity (MW) ........................... 49

Figure 7: Important Geothermal Markets Announced Planned Capacity Additions \&

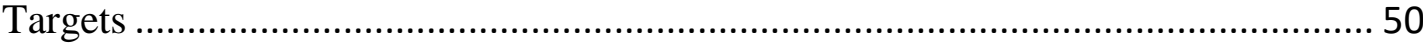

Figure 8: Established Geothermal Power Markets Installed Capacity (MW) .................. 51

Figure 9: U.S. Industry Geothermal Nameplate \& Net Capacity ………….................... 52

Figure 10: Developing Planned Capacity Additions \& Nameplate Capacity by State .... 53

Figure 11: Number of Developing Projects by State .................................................... 53

Figure 12: Operating Capacity by Technology Type …………………………......... 54

Figure 13: Major Geothermal Equipment Suppliers Megawatts Operating and Project

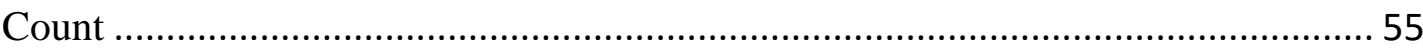

Figure 14: Geothermal Equipment Suppliers as Percent of Global Market by Projects .. 56

Figure 15: Geothermal Equipment Suppliers as Percent of Global Market by MW ........ 56

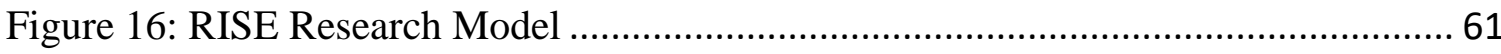

Figure 17: Hierarchical Decision Model for the Research Model ...................................... 64

Figure 18: The Impact of Geothermal Energy on Different Factors in the Environment. 72

Figure 19: Impact the Operation of Geothermal Project on the Employment ................. 75

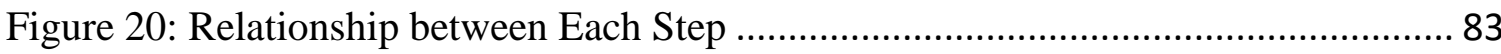

Figure 21: The Global Weight of Alternative Geothermal Energy Technology .............. 94

Figure 22: Individual Expert Judgment for Each Alternative............................................ 96

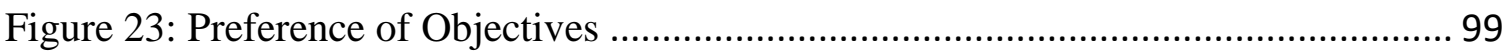

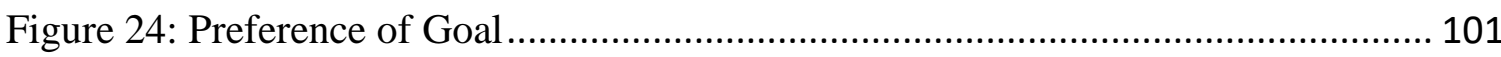

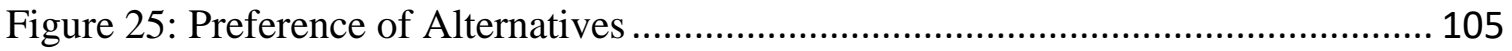




\section{CHAPTER 1: INTRODUCTION}

The demand for energy is increasing worldwide because the human population is increasing, and energy is very important in the development of all applications such as electricity, industry, agriculture, transportation, commercial building that serve the economy. Therefore, the demand for these applications has increased, thus increasing the cost because natural resources such as oil, natural gas, and coal cannot supply all of the energy consumers require because they are limited in many areas. In addition, in 2009 a report from British Petroleum (BP) (Statistical Review of World Energy) showed that between 1999 and 2008 there was an increase in the demand of natural resources. Oil rose to $15 \%$, natural gas to $33 \%$, and coal to $46 \%$, so we can see that the resources of energy are limited [1]. These applications contributed to increase the demand of all energy industry, and therefore the effect on the environment and the rise in pollution increased significantly [2]. The discussion about the lack of electricity will increase in the future as many applications are dependent on coal and petroleum to generate electricity. This is considered a large problem because these resources are decreasing at the same time that the population is increasing [3]. After 1970, researchers focused their research on renewable energy because they saw that renewable energy would reduce the cost of energy in the future. Moreover, with the development of technology and with trying to keep the economic sectors stable will require future energy strategies for communications between societal, political, institutional, and environmental. This process of the development of technology and future energy strategy will lead to clean energy, and will require the ability to analyze the cost and the risk for reaching the best 
outcome. The process will be complicated, and uncertainty will increase. This process will require a model that can be used to evaluate a flexible energy strategy to deal with many energy options [4]-[9].

In the United States, the department of energy gives a lot of attention to the use of renewable energy and supports a diverse range of research that focuses on applying renewable energy in different areas, which reflects a broad energy market. The government participated in the development of renewable energy through minimizing the tax and loan and making that in their policy [10]-[11]. In addition, they found that changing the work system (policy) will have a large effect on investment. The new policy work system supports renewable energy, which will lead to minimize the risk on financial premiums [12]. The United States government has spent more than $\$ 1$ billion between 1995 to 2000 to develop research in renewable energy, and the U.S has more development and updates of the information than other countries [11].

Geothermal energy has significant impact as a source of electricity generation. There are more than twenty countries that benefit from geothermal plants, which generate more than 6000 megawatts. The geothermal plants are considered as environmentally benign in terms of emissions abatement, water, and land-use as compared with other alternative of energies [13].

Geothermal energy is one of the most important renewable energies and the potential to obtain energy from it is huge, so the Department of Energy pays a lot of attention to development of the uses of this type of alternative energy to cover all 
applications in the United States such as electricity, heating and cooling for large building, homes, agricultures, sterilization [9]. Consumers' benefit from the heat of geothermal energy that comes from extracting the Earth's surface, and this energy is clean. There is no emission of pollution from this type of renewable energy, so it will not affect greenhouse emissions [14]-[15]. Most geothermal energy resources are available underground the Earth with different depths and forms of volcanoes, hot springs, and geysers [16]. The energy from geothermal resources with a depth of 10,000 meters can reach to 50,000 times more than other natural resources like oil and natural gas. Also, it makes nearly 68 billion kilowatt-hours of electricity that cover six million typical U.S households [17]. Many countries in the world like the United States, Italy, France, and Iceland have begun to depend on geothermal power plants, but most of the activities of geothermal energy occur in Japan, the Philippines, the Aleutian Islands, North America, Central America, and South America as these countries among Ring of Fire [18]-[20]. Most resources of geothermal energy that can be found in the United States are in California, Nevada, Alaska, Hawaii, Idaho, Oregon, Utah, and Wyoming [21]-[22].

Oregon is one of the eight states that currently using geothermal energy, and uses it in different applications such as generating industrial, agriculture, and commercial/ residential electricity [23]-[24]. So far the use of geothermal energy in Oregon is low, but the potential for success is very high when the opportunity is available to benefit from this type of renewable energy. This is why it's important to study the use of geothermal energy. Oregon has been ranked third in the potential use of geothermal energy after Nevada and California. Oregon depends on Geo-Heat Center at the Oregon Institute of 
Technology to supply all technical information that helps to develop geothermal applications [16]. Because of the high temperature of geothermal areas, Oregon has the ability to produce 2,200 megawatts of electricity. Since the 2009 installation of 0.3 megawatts of geothermal electrical plant in the Oregon Institute of Technology--Klamath Falls campus, many projects now are under construction in Oregon, and they are planning to reach the maximum use of geothermal energy. They work on the development of projects by increasing the production of electricity to reach 22 megawatts in Malheur County, 1.2 megawatts in the Oregon Institute location, and 3.1 megawatts in the progress of construction in Lake County. In addition, Oregon is close to having 2,200 thermal wells and springs that they can be used to provide direct heat to many facilities [25]. There are many investments in the field of geothermal energy, and the Office of Electrical \& Renewable Energy (EERE) invested 21.4 million with AltaRock Enhance Geothermal System (EGS) at the Newberry volcano close to Bend, Oregon. In this project successfully reduced the cost for development of geothermal resources [26][27].The Oregon Department of Geology and Mineral Industries provided new maps that clarify all hot springs, volcanic vents, examine the performance of the wells, and other resources of geothermal sources in the state [28].

One of the important aspects in geothermal energy projects is to look for economic analysis since it's preferred in literature. Multi Criteria Decision Making (MCDM) will be used in this study. We will also use the Analytical Hierarchy Process (AHP) since this process is complicated because requires looking at the problem from different sectors, assessing the model, and finally, reviewing the model to reach a final 
decision. MCDM techniques are successfully used in sustainable energy management. AHP is more the popular technique to use in different energy plan decision problems than PROMETHEE and ELECTRE [29]. MCDM is used to analyze and clarify the problem, by dividing the problem into multi decision criteria. MCDM is required to develop renewable energy by showing the uncertainty within more complicated processes, which leads to finding methodology that can handle different criteria and has ability to simplify the problem and make it easy to solve [30]-[32].

\subsection{Background of the Problem}

In Oregon, there is also the problem of supplying energy to all consumers. Many factors are affected by this problem, which has led the Department of Energy in Oregon to search for a suitable solution as they see the following problems. The consumption of total energy reached 773 trillion British Thermal Units (Btus) in 2000, and this amount of consumption increased to $15 \%$ compared to consumption in 1990. Moreover, closely half of the energy consumed comes from petroleum products and most this is used for transportation. The price is always increasing in Oregon as Oregon imports 100\% of natural gas and oil, which has an effect on the economy. In addition, the price of petroleum increased between 1999 to 2003 for residential heating oil, on-highway diesel, regular gasoline to $39 \%, 25 \%$, and $30 \%$, and the residential consumers increased to $23 \%$. The increase is higher for business customers. Also, between 1999 and 2004 the natural gas price increased by $168 \%$. Due to the rise in energy cost and the effect on the industry, in 2000 there was a loss of more than 14,700 manufacturing jobs out of 208,700., Also, natural gas is considered a critical component in chemical manufacturing. This affected 
more than $\$ 519$ million from the export from Oregon in 2005, and supported more than 3750 jobs [33]. The cost of electricity increased to $75 \%$, and between 2000 and 2007 the price of natural gas and transportation fuels increased to $91 \%, 102 \%$. In addition, climate change and peak oil are threatening the quality of life in Oregon. In addition to all of these problems that effect the potential to use the energy, buildings also had a large effect on energy consumption as it takes more than half of the total used energy, which leads to an increase in the search to improve building electrical and to increase the diversity of energy supply to these buildings [34]. All of these factors helped in the search to find other solutions that cover all these problems and they found the best thing to do is to use renewable energy. The world today tries to find the best way to benefit from natural resources such as water power, wind power, biomass, solar power, and geothermal energy that are sustainable energy generation and that reduce the cost to make renewable energy suitable to all consumers [3]. Due it its suitable environment and natural resources, Oregon has huge potential to use renewable energy alongside its electricity sector.

\subsection{Problem Statement}

Although the American Council for an Energy Efficient Economy (ACEEE) considered Oregon the third in electrical, Oregonians consume annually approximately $\$ 15$ billion on energy, and they still work to minimize the cost of energy to maintain on both environmental and public health costs. In the legislature created for the Oregon Department of Energy in 1975, there is a requirement to review the continued growth for renewable energy forms to avoid problems that will occur in the future. Today there are 
many difficulties to improve the opportunities to use renewable sources, such as it's hard to match the demand of energy with increasing population so the opportunity to use renewable sources would give the opportunity to serve users' energy requirements and maintain electrical. Improvement for clean energy creates a positive impact on the environment and Oregon has opportunity to do that. So it's important to have remote renewable energy generation resources accessible to an area that has a heavy load of demand energy, and to create greater resiliency to the Western Electric grid in the next 30 years [35]. Geothermal sources have the ability to deal with environmental and health costs because it's clean energy and it can generate clean energy. Also, it can be installed in different areas to serve different cities, and it can be modified to connect with the electrical grid.

In 2012, Oregon released a ten year energy action plan because it's difficult to reach a $100 \%$ of new electric growth without working with public buildings. The State Building Innovation Lab (SBIL) works to create deep energy savings into public buildings through working with lab pilot innovation in financing and program design. For creating benchmarks, it requires a data model and works to improve the model by coordinating with other entities and shaping data standardization. This process calculates cost efficiency for the next ten years. There will be difficulties in clean energy infrastructure improvement unless finance and regulating barriers are removed [35]. From the literature review on geotechnical energy, research studies showed that geothermal sources are a requirement for future progress in reducing the energy load as public buildings consume a lot of energy, and that requires a recalculation of all processes of energy consumption 
and looking for best way of using energy. In the end, this will maintain the environment and reduce the financial cost.

On the part of consumption, although Oregon has diversity of energy resources by depending on petroleum, natural gas, renewable energy to cover all the consumption in the state, the main energy sources go to home heating. In 2012, electricity use for home heating was $50 \%$, natural gas was $37.5 \%$, and fuel oil was $2.5 \%$. Most of energy consumption goes to transportation, which uses annually sixty three million barrel of petroleum. According to the Energy Information Administration in 2012, Oregon consumption by end use sector $30.7 \%$ for transportation, $25.1 \%$ for residential, $25.0 \%$ for industrial, $19.1 \%$ for commercial. It's necessary to find a solution to the pollution that comes from the transportation industry. Most people in Oregon use cars that depend on gasoline, and a few people use electric vehicles [35]. We can use renewable energy like geothermal energy for commercial, industrial, and residential use thereby reducing the dependence resources like petroleum, and reduce the effect of pollution on the environment.

Much of the electricity supplied to Oregon energy consumers comes from outside of the state. The nuclear power comes to Oregon via the Bonneville Power Administration that depends on the Columbia Generating Station in Hanford, Washington. Coal covers $33 \%$ of the requirement for electricity, and the source comes from Portland General Electric (PGE) in Boardman, Oregon, as well as plants in Utah, Wyoming, and Montana. With the creation of new wind facilities in 2011, PGE revised and decided to terminate the use of the Boardman coal plant by December 2020 [35]. The 
use of wind and geothermal sources and other alternative energies will create more dependence on Oregon's own resources.

According to the Energy Information Administration (EIA), the price of natural gas fluctuates each year. The rate of electricity per sector also increases each year. Commercial rates increased to 8.68 cents/kwh in 2014 compared to 7.57 in 2010, and industrial rates increased to 6.29 cents/kwh in 2014 compared to 5.65 in 2010 . The EIA shows the increase in the retail price of electricity in residential, commercial, industrial, and transportation sectors [35]. The use of geothermal sources will create a constant price rate if Oregon knows how to obtain the full advantage of this resource, and ultimately this will reduce the price of energy.

In terms of carbon emissions, Oregon is trying to find the best way to address climate change by making several changes by evaluating proposed carbon reduction plans. This process for developing the plan is complicated because it needs collaboration between the Oregon Department of Environment and other state agencies, and requires many mechanisms to achieve the carbon reduction required by the plan. One proposed outcome is to reduce carbon emission by about $50 \%$. The closure of the coal station at Boardman will support this outcome by 2020[35]. Using geothermal sources will lead to the reduction of carbon emission since geothermal sources will not effect on the environment.

Oregon consumes a lot of thermal energy, and $80 \%$ come from natural gas and electricity. Thermal energy is used in different applications like heating and cooling for 
our homes and buildings. By the end of 2009, Oregon use by sector showed $51 \%$ for industrial, $32 \%$ for resident, and $17 \%$ for commercial purposes [35]. Using geothermal sources will lead a reduction in the load on the electric system.

Nuclear energy is also a risk to people who live in Oregon, especially those people who live within the 50-mile nuclear emergency planning zone in Hanford and Columbia Generating Stations in Washington. Approximately 29,000 people live in the communities of Boardman, Irrigon, Hermiston, and Umatilla, Oregon. Any accident that leads to a fire or an explosion generates an airborne release of radioactive materials. The Oregon Department of Energy (ODOE) worked extensively with Morrow and Umatilla counties and other agencies through inspection regularly their emergency preparedness programs. Theses counties stopped receiving funds supporting their emergency preparedness program in 2012, although they still participate in nuclear emergency planning [35]. Using geothermal sources will effectively reduce the risk that comes from nuclear energy, and it will be safer for people who live in this area.

There is good opportunity to invest in renewable energy because Oregon has made progress from ranking 35th in the country in 2010 to ranking 30th in 2012 by making 497 trillion Btu of renewable energy. Geothermal is a good investment for this progress of renewable energy production, as Oregon has the third ranking in the opportunity for having energy after Nevada and California [35]. 


\subsection{Research Objective:}

The objective from the research study is to find the assessment model framework that can be used for supporting electrical in Oregon by the development of geothermal energy sources. The research study works through collaboration between utility objectives and goals for filling the gap that is available, and works to have a solution by making a comprehensive decision- making process to evaluate the accurate outcome. Multi Criteria Decision Making (MCDM) is a suitable tool to do the decision -making process. This approach will help to evaluate the diversity of users, which will reduce the uncertainty associated with this diversity [30]-[32]. Overall, the research model will increase the knowledge about how to develop geothermal energy sources for supporting electrical system in Oregon. And thus to minimize the uncertainties in decision making, create a better understanding of the potential applications in different areas inside of Oregon, and to find the optimum way to reach electrical.

The research development model for geothermal energy sources will try to find answers to the following research question:

- What are the criteria for assessing the support of the electrical system from geothermal energy sources?

- Which geothermal energy resource alternative has the highest impact for developing the electrical system?

- How will changes in the energy resources effect in the analysis for making decisions? 
- What are the current technologies that are available that will allow for the more efficient extraction of geothermal resources, and that will be more effective in the electrical system?

The research questions listed above try to support the achievement of the research objective in the following ways:

- To identify the main criteria that affect the enhancement of the electrical system by depending on geothermal energy resources.

- To develop a multi-criteria model for enhancing geothermal energy resources that better reflects the electrical system by collecting information from different sectors, which will create better usage from the electrical system.

- To identify and rank the main technologies that support the adoption of geothermal production in the Oregon. 


\section{CHAPTER 2: LITERATURE REVIEW}

\subsection{Decision Making in Energy Planning}

In the 1970s, researchers focused their studies on creating a single outcome that was focused on the economics of renewable energy, which motivated them to create small model interactions with the energy- economic sectors. The stated goals were to have a constant price and to establish the role of structured parameters. Through this structure, they were able to calculate the total expenses of the energy sectors and could understand the best way to keep energy-economics cost effective [36]-[38]. With continuous demand on energy, different issues began to show in terms of energy planning since one dimension, such as the economy cannot solve the complicated process. Because of its popularity in solving complicated processes, MCDM began to be used in decision making for sustainable energy. MCDM is successful in dealing with the multi-dimensions of sustainability goals, and in the combination of socio-economic and biophysical systems. MCDM differs from previous methods, which work with one-dimension only, and it works with different criteria in the energy supply system from technical, economic, environmental, and social aspects. Different comprehensive MCDM methods are used for this purpose: Analytical hierarchy process, TOPSIS, and ELECTRE. MCDM works with decision uncertainty, and helps the decision- maker to choose the best acceptable innovation technology in the energy sector [30][39]-[42].

After the exploration of oil and gas in 1960s, many studies found that decision analysis (DA) was important in solving complicated problems, and that contributed to the use of DA in the application from industry to the public sector. DA can be used as 
strategic or policy decision making for solving uncertainties and multiple conflict criteria. The energy and environmental issue $(\mathrm{E} \& \mathrm{E})$ is complicated because it requires dealing with multiple objectives since it deals with many uncertainties in decision making, a long time frame, capital investment, and a large number of stakeholders which requires DA for solving this issue. Decision analysis methods can be divided into three groups: Single objective decision making (SODM) method, Decision Support System (DSS), and MCDM method and this shown in the figure below:

Figure 1: Decision Analysis Methods with Branches

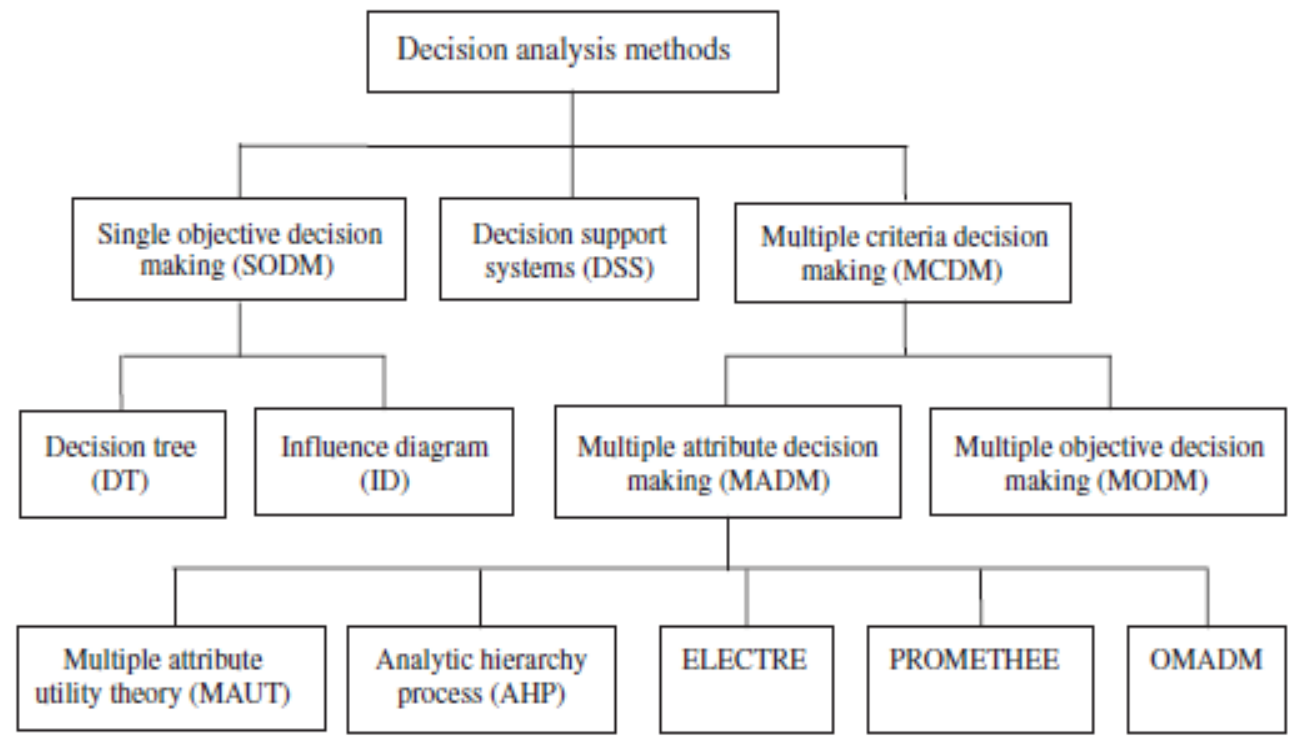

SODM: Works with a class of methods for reaching the available solution under a single objective situation. SODM is into a Decision Tree (DT) and an Influence Diagram (ID) Both work to make SODM a simpler and more compact representation of decision problems. 
MCDM: Gives the decision maker the choice to prioritize alternatives by depending on several criteria. MCDM has mainly two branches: Multiple Objective Decision Making (MODM) and Multi Attribute Decision Making (MADM). The reason to choose MODM is to find the best among alternatives. MADM is to the popular choice to use in energy planning.

DSS: Uses flexible and adaptable software systems that cover models, databases, and other decision aiding tools.

From different studies, it was observed that decision making in energy planning can be used in different applications, and it can be narrow into two groups: Strategy /Policy(S/P) and Operational/Tactical (O/T) levels. The S/P level works with macro issues like energy policy analysis, energy investment planning, and energy conservation strategies. The O/T level works with operational and short term development like bidding, pricing, and technology choice. After that it has seven application areas: energy policy analysis, electric power planning, technology choice and project appraisal, energy utility operations and management, energy- related environmental policy analysis, energy-related environmental control and management, and miscellaneous category. Small clarifications about each application are below [43]:

Energy policy analysis: Works for an assessment of the energy system through improvement and formulation of energy policy. This branch of energy works for regional assessment, public debate on energy policy, energy conservation strategies, and energy resource allocation. 
Electric power planning: Works with strategic planning in power generation, transmission, and distribution.

Technology choice and project appraisal: Works with energy technologies and the appraisal of energy that leads to investment in the project. This branch of energy must be classified under electric power planning when the availability of both technology and investment are part of the project.

Energy utility operations and management: Works with the operational issue in the energy industry like energy biding and pricing, power plant siting, and management of energy companies. This branch of energy works with all energy sources.

Energy- related environmental policy analysis: This is at the policy level, and is related to assessing the environment, and it works to solve the problem. These problems are the assessment of climate policy, public debate on green-house warming, and air pollution control policy.

Energy-related environmental control and management: Works to cover different aspects like solid waste management, evaluation of waste storage sites, and environmental analysis that match development of the project.

Miscellaneous category: This branch is customized to work with any problem that can't be solved with the six branches mention above.

MCDM is important to use with all of these branches since each branch has goals that are different from the others. The table below clarifies why MCDM is more actively 
used than SODM, and how both MCDM and SODM can work with the seven of application above:

Table 1: MCDM Shows More Active than SODM

\begin{tabular}{|c|c|c|c|c|c|c|c|c|c|c|}
\hline \multirow{2}{*}{$\begin{array}{l}\text { Applicatio } \\
\text { n Area }\end{array}$} & \multicolumn{2}{|c|}{$\begin{array}{c}\text { SOD } \\
\text { M }\end{array}$} & \multicolumn{5}{|c|}{ MCDM } & \multirow{2}{*}{$\begin{array}{c}\text { DS } \\
\text { S }\end{array}$} & \multirow{2}{*}{$\begin{array}{c}\text { Othe } \\
\text { rs }\end{array}$} & \multirow{2}{*}{$\begin{array}{l}\text { Total } \\
\text { numb } \\
\text { er }\end{array}$} \\
\hline & \begin{tabular}{l|}
$\mathbf{D}$ \\
$\mathbf{T}$
\end{tabular} & $\begin{array}{l}\text { I } \\
\text { D }\end{array}$ & $\begin{array}{c}\text { MOD } \\
\text { M }\end{array}$ & $\underset{T}{\text { MAU }}$ & $\begin{array}{c}\mathbf{A H} \\
\mathbf{P}\end{array}$ & $\begin{array}{c}\text { ELECT } \\
\text { RE }\end{array}$ & $\begin{array}{c}\text { PROMETH } \\
\text { EE }\end{array}$ & & & \\
\hline $\begin{array}{l}\text { Energy } \\
\text { policy } \\
\text { analysis }\end{array}$ & 1 & 0 & 18 & 8 & 20 & 3 & 2 & 4 & 11 & 60 \\
\hline $\begin{array}{l}\text { Electric } \\
\text { power } \\
\text { planning }\end{array}$ & 2 & 1 & 3 & 4 & 6 & 0 & 0 & 2 & 5 & 27 \\
\hline $\begin{array}{c}\text { Technology } \\
\text { choice and } \\
\text { project } \\
\text { appraisal }\end{array}$ & 11 & 4 & 1 & 7 & 7 & 2 & 3 & 1 & 2 & 32 \\
\hline $\begin{array}{c}\text { Energy } \\
\text { utility } \\
\text { operations } \\
\text { and } \\
\text { manageme } \\
\text { nt }\end{array}$ & 19 & 4 & 6 & 13 & 4 & 3 & 2 & 11 & 2 & 54 \\
\hline
\end{tabular}




\begin{tabular}{|c|c|c|c|c|c|c|c|c|c|c|}
\hline $\begin{array}{c}\text { Energy- } \\
\text { related } \\
\text { environme } \\
\text { ntal policy } \\
\text { analysis }\end{array}$ & 3 & 0 & 2 & 4 & 9 & 1 & 2 & 3 & 7 & 27 \\
\hline $\begin{array}{c}\text { Energy- } \\
\text { related } \\
\text { environme } \\
\text { ntal control } \\
\text { and } \\
\text { manageme } \\
\text { nt }\end{array}$ & 4 & 4 & 1 & 11 & 4 & 5 & 1 & 6 & 10 & 43 \\
\hline $\begin{array}{c}\text { Miscellane } \\
\text { ous }\end{array}$ & 1 & 0 & 0 & 1 & 2 & 0 & 0 & 2 & 3 & 9 \\
\hline $\begin{array}{c}\text { Total } \\
\text { number }\end{array}$ & 41 & 1 & 41 & 48 & 52 & 14 & 10 & 29 & 40 & \\
\hline
\end{tabular}

From the literature, it is important in decision analysis studies to focus on energy planning to have methods to simplify this process. The methods in decision analysis can be divided into the following aspects: economic analysis, decision analysis, and system analysis methods.

\subsubsection{Economic Analysis Methods}

Tools that can be used with economic analysis method are divided into:

Cost/Benefit Analysis

Cost Effectiveness Analysis 


\section{Life-cycle Cost Assessment}

Payback Period Analysis

Real Option Analysis

\subsubsection{Cost/Benefit Analysis}

Cost benefit analysis has two parts and it requires both sides to work. The first part of the cost benefit analysis is the measuring of costs and benefits with the progress in the time, and which is evaluated in terms of the willingness to pay. For benefits, this means choosing the maximum amount can be paid for reaching this purpose. For costs, this means choosing the minimum amount that can be paid for reaching this purpose. The second part consists of cost benefit criterion that is decided by choosing the project if the net present value of benefit is positive and to refuse the project if the net present value negative [44].

Cost benefit analysis is used in a diverse array of applications, like global climate policy [44], climate change [45], power generation [46], wind energy [47], technology and environmental policy [48], domestic electrical [49], local air pollution and global climate change [50], and waste-reuse project for environmental purposes [51].

Cost benefit analysis is easy to use, and anyone can understand the results from using this method. It can be used in different locations, scenarios, and applications. At the same time, cost benefit analysis has drawbacks. For example, if a person wanted to calculate the cost- benefit of the project to have an accurate calculation here was a mistake, this would lead to a change in the result and the need to re-calculate the process. 


\subsubsection{Cost Effectiveness Analysis}

Cost effectiveness analysis was improved through the World Health Organization (WHO).This improvement reflects the assessment of the efficiency in different interventions and scenarios. This method works to clarify the intervention scenario and to enhance the effectiveness in every scenario [52]. This method cannot work with cost and benefit, which works with cost benefit analysis.

Cost effective analysis is used a diverse array of applications like energy production in the EU [53], climate policy [54]-[57], wind/pv/ fuel cell power generation system [58], renewable energy electricity policy [59], new commercial building [60], air quality and greenhouse gases [61], and global warming [62]-[64].

Cost effective analysis is similar to cost benefit analysis because it is easy to understand. Also, it can work with different programs that deal with same disease or goal. Cost effective analysis like cost benefit analysis has limitations and drawbacks. The organization of the analysis is not the same for reaching calculations and that impacts the results. For example, some researchers found that it placed the same value on every individual and it did not take into consideration age (infant and middle age assumed equal). Another study found that the calculation of the years of an individual impacted their life.

\subsubsection{Life-Cycle Cost Assessment}

Life cycle cost assessment works to estimate the cost of the whole life of the product that collaborates with the system through present and future cost. The goal from 
using this method is to evaluate the total cost of project alternatives, and to choose the design that supports the lowest in general and that reflects on quality and function [65].

Life cycle cost assessment can be used in a diverse array of applications like energy building [66]-[69], alternative fuel [70], environmental analysis [71]-[73], sustainability [74]-[76], greenhouse gas emission [77]-[79], object oriented framework for highway bridge [80], and solar energy [81].

The result from using life cycle cost analysis leads to more revenue or lower cost when this method takes in these into consideration. In addition, the best decisions will be made since it provides more accurate information, and thus a realistic assessment of revenue and cost will be generated. However, life cycle cost can lead to financial problems when the cost of the business increases more than customization budget.

\subsubsection{Payback Period Analysis}

Payback period analysis is the duration of time that is required to get a return on the money that was invested over a certain period of time. A long-term payback period is no favorable. A short-term payback period is more desirable. This method is more important because it determines if the investment or project is acceptable or not.

Payback period analysis can be used many different applications like evaluation of photovoltaic system [82]-[86], electricity generation power plant [87]-[88], wind energy [89]-[90], environmental analysis [91]-[92], solar hot water system [93], commercial building application [94]-[96], and carbon dioxide emission [97]-[98]. 
Payback period analysis has many advantages. For instance, this method is easy to use and calculates the result, giving a more accurate assessment in the final decision for reaching the investment proposal, An assessment of the risk will occur, and the degree of certainty depending on period of the risk. Besides all of these advantages, it has disadvantages. For instance, the calculation for payback and time value of money is not clear in the result. In addition, it focuses a lot of attention on liquidity and leaves off profitability.

\subsubsection{Real Option Analysis}

Real option analysis considers alternatives when opportunity is available for business investment by looking at real, tangible assets. Real option analysis is used when there is the ability to expand and cease projects, and when many conditions make it difficult to choose between alternatives. This process will help decision makers to make decisions accurately.

Real option analysis can be used for different applications like sustainability [99]-[100], hydropower energy [101], high uncertainty technology investment [102][103], renewable energy [104]-[105], carbon emission [106]-[107], risk management [108], and challenges in making decision [109].

Real option analysis is useful in helping decision makers accurately choose between the best alternatives according to situation.

The table below summarizes the economic analysis with the tool according to literature review. 
Table 2: Methods Used in Energy Planning with Respect to Economic Analysis from the Literature

\begin{tabular}{|l|c|c|}
\hline Type of evaluation & Methods & Reference \\
\hline \multirow{4}{*}{ Economic Analysis } & Cost benefit Analysis & {$[44]-[51]$} \\
\cline { 2 - 3 } & Cost effective Analysis & {$[52]-[64]$} \\
\cline { 2 - 3 } & Life-cycle cost Assessment & {$[65]-[81]$} \\
\cline { 2 - 3 } & Payback period Analysis & {$[82]-[98]$} \\
\cline { 2 - 3 } & Real Option Analysis & {$[99]-[109]$} \\
\hline
\end{tabular}

\subsubsection{Decision Analysis Method}

Tools that can be used with decision analysis method divide into

Decision Trees

Influence Diagrams

Multi-Attribute Utility Theory

Analytic Hierarchy Process (AHP)

Analytic Network Process (ANP)

PROMETHEE

ELECTRE

\subsubsection{Decision Trees}

Decision trees work by finding a course of action or to show a statistical probability. Every branch in the decision tree means the probability of the decision. 
These branches help to simplify complex decisions and according to decision trees, the most viable alternative will be selected.

Decision trees can be used in variety of applications like forecast application [110], cost effective operation strategy [111], electric energy consumption [112], solar and wind power [113], renewable energy policy [114]-[115], environmental affect [116][117], building energy [118]-[119], enterprise-wide modeling \& optimization [120], and program model in energy [121].

There are many advantages in using decision trees. Decision trees are not complicated, are easy to understand, and are simple to execute. Also, the performance will not be affected when the trees have a nonlinear relationship. Decision trees require little effort for data preparation as compared with other methods. The decision tree does have problems when it is supplied with continuous data. For example, it is unstable because when decision trees change the data, this leads to a change in the calculation for future data.

\subsubsection{Influence Diagram}

An influence diagram shows problems that need decisions to be made in order to solve them. It shows different shapes and colors for decisions, uncertainties, and objectives as nodes in the network. In the influence diagram, there are four types of nodes that create the decision problem. These nodes explain the situation ' what do we do?', "what is the outcome?", and finally, " How do we like it?". 
Influence diagrams work in a diverse set of applications such as life cycle assessment of renewable energy [122], ranking cycle for waste heat recovery [123], organization of renewable energy [124]-[125], building energy [126], analysis frameworks [127], sustainable energy system [128], and wind energy [129].

An influence diagrams has many advantages. For example, in the case of quantitative information, it simplifies the cause and effect phenomena. Also, the benefit of the model influences the diagram though up keeping and upgrading. It has a function of open windows instead of black boxes. However, influence diagram has limitations for use. For example, although the model is easy to understand, it is difficult to build the model.

\subsubsection{Multi-Attribute Utility Theory (MAUT)}

Multi-Attribute Utility Theory (MAUT) works as a tool to solve complicated decision making problems. This complicated process results from the probability nature of the problem, and a multitude of quantitative and qualitative factors. Kenny and Raiffa [130] developed a concept for solving complicated decision problems through multiple attributes and multiple conflicting objectives, which leads to a systematic approach of multiple attributes utility analysis. MAUT solves the problem for decision makers by simplifying the structure in the form of a simple hierarchy. This process impacts the solution for a large number of uncertainties in both cases quantitative and qualitative [131]. 
MAUT works in different applications such as energy policy [132]-[133], risk analysis [134], power plant [135], climate change mitigation [136], environmental analysis [137], building energy [138], green supply energy management [139], wind energy [140] and decision models for project selection [141].

MAUT has many advantages and it can participate in the different aspects such as economic, environment. It must have more data than MOP. In addition, it has less difficulty in the computations than MOP [131]. Although MAUT has advantages, it has some limitations. For example, in the program goal MAUT doesn't have the ability to weigh coefficients, and that the reason why many researchers use another methods like AHP. The huge amount of input that is required in every step for reaching accuracy in the decision outcome will lead to intensive data, which may not be found in every step in the process of decision making [142].

\subsubsection{Analytic Hierarchy Process (AHP)}

AHP is used for solving complicated decision making. There have been many developments in this method by Thomas L. Saaty in the 1970s. It is acceptable in different scientific communities to solve complicated decisions in technical part and environment [143]-[144]. Also, this method facilitates the long decision process by dividing it into smaller elements to make the decision process easier [145]. In addition, the pair-wise comparison is used to help make decisions, and Satty suggests using a 1-9 scale measurement and eigenvector [145]. While Kocaoglu suggests using 100 points between each pair [146]. 
AHP is successfully used in different applications such as long- term improvement in the national electrical and GHG control panel [147], energy alternatives for the household [148], development of hydrogen technology [149], energy policy planning [150], renewable energy planning [151]-[152], transportation fuel policy [153], and environment impact assessment [154].

The process of AHP has many stages before reaching a decision. The first stage is the target, which is represented by the selection of the best alternative among others. The second stage works to evaluate the criteria according to the alternative. The third stage makes a hierarchy by simplifying a complex problem into a small problem. The fourth stage evaluates if the hierarchy arranged is suitable or not according to the target. The fifth stage creates an online peer-review system. On the sixth stage makes the pairwise comparison, and calculate the weight of the criteria after that. The seventh and eighth stages examine the consistency. The ninth stage reviews the consistency of the ratio, which must be between 0 and 0.1 . After the completion of all of the stages, it must go the tenth stage to select the best alternative that leads to the best development of alternative energy technology [147].

\subsubsection{Analytic Network Process (ANP)}

ANP is a tool for making decisions, and it has the flexibility to use interaction and feedback during and between clusters. The feedback is very important for the process of making decisions, and it develops the process of decision in the human society. The framework that contains the cluster of elements has a major effect on creating ANP. That impact is the desired way for reaching the process of deriving ratio scales. ANP was 
improved by Saaty as a new concept for expansion of AHP. The advantage of using ANP is to use ratio scales to capture all kinds of interaction [155].

ANP is used in different applications like alternative fuels for electricity generation [156]-[157], SWOT analysis [158], selection of photovoltaic solar power plant investment projects [159], sustainable building energy [160], environment impact[161]-[162], strategies analysis for $\mathrm{CO} 2$ reduction management [163], and solar energy industry [164].

Although there are advantages in using ANP for different applications, it has some limitations. For example, there are challenges in choosing the correct network structure among other criteria because the different structures impact the result and the experts too. Also, it has difficulties in forming a super-matrix, and all criteria must be in pair-wise comparison with respect to other criteria [165].

\subsubsection{PROMETHEE}

The PROMETHEE method was developed in 1982 by Brans, and improvements were made to this method during the period between 1985-1994 by Brans, Vincke, and Mareschal. This method considers outranking as it works to complete aggregation (MAUT) and it needs additional information. PROMETHEE has three major tools that is uses to simplify and solve a problem: PROMETHEE 1 ranking, PROMETHEE 2 complete ranking, and PROMETHEE 3 GAIA plane [166].

PROMETHEE is successfully used in many applications like sustainable energy planning [167]-[168], national energy scenarios [169], evaluation of geothermal energy 
projects [170], evaluation of wind energy [171], decision making in fuzzy environment [172], distributed residential energy systems [173], assessment of solar thermal technology [174], and chemical emissions on motor vehicles [175].

PROMETHEE has many advantages when it is used. For example, PROMETHEE 1 works to prevent occurring trade-offs between scores on the criteria, which is more likely to happen with AHP. PROMETHEE doesn't need a lot of effort to reach synthesis, and that leads to completion without a lot of effort for each alternative on every criteria. However, PROMETHEE has some limitations. PROMETHEE 1, the partial ranking, when it prepares to complete the ranking PROMETHEE 2 of the alternative, the specific details are usually lost during the transfer. PROMETHEE doesn't have the ability to build a classical decision tree or another guideline to eliminate the weight that occurs only with a criteria hierarchy [166].

\subsubsection{ELECTRE}

The ELECTRE method is part of MCDA, and it was used in the 1960s. This method was discovered by Bernard Roy and his colleague at SEMA Company. This method has ability to deal with difficult situations in both quantitative and qualitative for supplying the order of the alternative [29]. In addition, it works with uncertainty and vagueness that lead the creation of data from predictions and estimations [176].

The ELECTRE method works in different applications like thin-film photovoltaic production processes [177], aids approach for energy planning problems [178], environmental modeling [179], selection for alternative energy [180], promoting 
electrical [181], integrated decision aid [182], and assessment of renewable energy sources [183].

The ELECTRE method has advantages. For example, it has the ability to make the decision by selecting the decision parameters, and depending on the intervals can ignore the fixed value [184]. However, it has some limitations. For example, sometimes this method is unable to choose the best alternative because it isn't require to finish the task in the system [29].

The table below summarizes the decision analysis with tools according to literature review.

Table 3: Decision Analysis Used in Energy Planning from the Literature

\begin{tabular}{|l|c|c|}
\hline Type of evaluation & Methods & Reference \\
\hline \multirow{4}{*}{ Decision Analysis } & Decision Trees & {$[110]-[121]$} \\
\cline { 2 - 3 } & Influence Diagram & {$[122]-[129]$} \\
\cline { 2 - 3 } & MAUT & {$[130]-[142]$} \\
\cline { 2 - 3 } & AHP & {$[143]-[154]$} \\
\cline { 2 - 3 } & ANP & {$[155]-[165]$} \\
\cline { 2 - 3 } & PROMETHEE & {$[166]-[175]$} \\
\hline
\end{tabular}

\subsubsection{System Analysis Methods}

Tools that can be used with system analysis method divide into

Simulation Modeling and Analysis 


\section{System Optimization}

\section{TOPSIS}

\subsubsection{Simulation Modeling and Analysis}

It's a method to analysis a digital prototype of a physical model to guess its performance in the real world. Engineers and designers benefit from this method to determine and understand the conditions, such as which part can fail and which part can be successful in all processes of testing.

Simulation modeling and analysis works in different kinds of application such as building energy performance [185], the dynamic behavior of a polymer electrolyte membrane fuel cells [186], system analysis for advanced vehicles [187], emerging technology [188], architecture for sparse sensor networks [189], end-use energy consumption in the residential sector [190], software process simulation [191], and daylight availability and irradiance components from direct and global irradiance [192].

Simulation modeling and analysis has many advantages when it is applied in different applications. For example, it can reduce the calculation that requires many years to obtain by impacting the quickly changing environment in real life by depending on the use of a computer system within a considered time frame. Also, it works to simplify the complex problem where there is no easy way to reach the result. Finally, it can be used for obtaining a result that is beneficial to avoid the occurrence of a dangerous situation in real life. Moreover, it doesn't have ability to understand all physical systems, which can affect the ability to have enough data to create a mathematical model. This complex 
system requires a computer system with a fast processor and a large amount of memory for solving complicated processes. Finally, the formula and function cannot reach accurate results in the system from the simulation.

\subsubsection{System Optimization}

This method is part of system science, and it is used to minimize the running process in a computer, changing work mode, deleting unnecessary break offs for more efficient computer performance, etc. System optimization works in many fields like, clean windows, temp files in the Temp Folder, free disk space, and minimizing the possibility of system errors. This process creates more efficiency and use of resources for obtaining best result.

System optimization can work in different kinds of applications such as energy management system planning [193]-[194], stand-alone hybrid solar-wind system [195], photovoltaic power systems [196], advanced alkaline electrolyzers [197], methods applied to renewable and sustainable energy [198], sensitivity analysis of photovoltaic system in residential buildings [199], district heating systems [200], and future energy systems [201].

System optimization has many advantages when it is used in different applications. For example, it is successful in the business process impact to have more efficiency, and this leads to more efficient ways of using resources, minimizes stress, and assists people in being more productive with their time. In addition, the cost of usage will be reduced when using system optimization since it helps to minimize errors and obtains 
a high quality of improvement in the result. Finally, accuracy of information will be increase when users use this method. Yet system optimization has disadvantages. For example, engineers can use the function technique to find optimal calibration by depending on iterative procedures that interact with a computer program.

\subsubsection{TOPSIS}

The Technique for Order of Performance by Similarity to Ideal Solution (TOPSIS) is considered a multi-criteria decision analysis. This method was improved by Hwang and Yoon in 1981. TOPSIS works through taking the shortest geometric distance from the positive ideal solution and the longest geometric distance from the negative ideal solution. It works through comparing a set of alternatives by determining the weight for every criterion, normalizing the score for every criterion, and finding the result of geometric distance between every alternative and the best alternative.

TOPSIS can work in a diverse array of applications such as assessing thermalenergy storage [202], state -of -the -art survey [203], energy efficient network selection [204], automotive industry [205], reduction on pollution emission base [206], evaluation and selection of thermal power plant location [207], building energy performance with multi-criteria technique for order preference [208], and the integrated framework for analysis of electricity [209].

TOPSIS has many advantages when it is used. For example, the process is easy to use since the number of steps will stay the same without changing when it has a number of attributes. The disadvantages are that the geometric distance doesn't give attention to 
the correlation between attributes, and it is hard to weight attributes and maintain consistency of judgment.

Table 4 : System Analysis Used in Energy Planning from the Literature

\begin{tabular}{|c|c|c|}
\hline Type of evaluation & Methods & Reference \\
\hline \multirow{3}{*}{ System Analysis Method } & $\begin{array}{c}\text { Simulation Modeling and } \\
\text { Analysis }\end{array}$ & {$[185]-[192]$} \\
\cline { 2 - 3 } & System Optimization & {$[193]-[201]$} \\
\cline { 2 - 3 } & TOPSIS & {$[202]-[209]$} \\
\hline
\end{tabular}

\subsection{Research Gap Analysis}

From the literature review (academic journals, web articles related to energy technology) it has been observed that it is important to focus on the following areas:

- The different procedures and systems that are required for renewable energy for development of resources.

- The requirements of using renewable energy to support electrical systems.

- Decision making methodology in energy planning.

Table below clarifies the key research areas and findings from the literature review:

Table 5: Key Research Area and Finding in the Literature

\begin{tabular}{|c|c|c|}
\hline Research area & Finding & Literature \\
\hline $\begin{array}{c}\text { Different procedure and } \\
\text { system require for renewable } \\
\text { energy for development the } \\
\text { resources }\end{array}$ & $\begin{array}{c}\text { Complicated process of } \\
\text { development renewable } \\
\text { energy and increasing } \\
\text { demand to have energy and } \\
\text { maintain on social, political, }\end{array}$ & {$[4-9],[10][11]$} \\
\hline
\end{tabular}




\begin{tabular}{|c|c|c|}
\hline & $\begin{array}{l}\text { environment, economic, and } \\
\text { technical. Minimizing tax, } \\
\text { granted loan from the } \\
\text { government. }\end{array}$ & \\
\hline $\begin{array}{c}\text { Support energy efficiency } \\
\text { system }\end{array}$ & $\begin{array}{l}\text { Geothermal energy resources, } \\
\text { seven application areas: } \\
\text { energy policy analysis, } \\
\text { electric power planning, } \\
\text { technology choice and } \\
\text { project appraisal, energy } \\
\text { utility operations and } \\
\text { management, energy- related } \\
\text { environmental policy } \\
\text { analysis, energy-related } \\
\text { environmental control and } \\
\text { management, and } \\
\text { miscellaneous category. }\end{array}$ & [9], [15], [24], [29], [43] \\
\hline $\begin{array}{l}\text { Decision making } \\
\text { methodology in energy } \\
\text { planning }\end{array}$ & $\begin{array}{l}\text { (DA) is important to solve } \\
\text { complicated process. DA can } \\
\text { be used as strategic or policy } \\
\text { decision for solving } \\
\text { uncertainties and multiple } \\
\text { conflict criteria, energy } \\
\text { planning requires multi } \\
\text { criteria to solve complicated } \\
\text { process since one dimension } \\
\text { cannot solve these criteria } \\
\text { from one dimension. MCDM } \\
\text { applies in different sector of } \\
\text { energy planning. }\end{array}$ & $\begin{array}{c}{[29],[30]-[32],[39]-} \\
{[42],[43],[55]-[58],[147]-} \\
{[154],[155]-[165],[166]-} \\
{[175],[176]-[183]}\end{array}$ \\
\hline
\end{tabular}

From the research findings in this table, many research gaps have been identified.

Many of the research gaps were found from the literature and from other scholars.

These gaps are the need to

- Find systematic approaches through enhancing electrical systems by depending on geothermal energy resources. 
- Improve a multi-criteria model for enhancing geothermal energy resources that reflects on better electrical systems.

- Collect information from different sectors that can benefit from electrical systems.

For finding solutions to these gaps, several questions were used. They are listed below:

- What are the criteria for assessing the support of electrical systems from geothermal energy sources?

- Which geothermal energy resources alternatives have the highest impact for developing the electrical system?

- How can changes in energy resources affect in the analysis for making decisions?

- What are the current technologies available for developing and extracting geothermal resources that will be more effective in the electrical system?

Figure below clarifies research gaps, goals, and questions. 
Figure 2: Research Gap, Goals, and Research Question
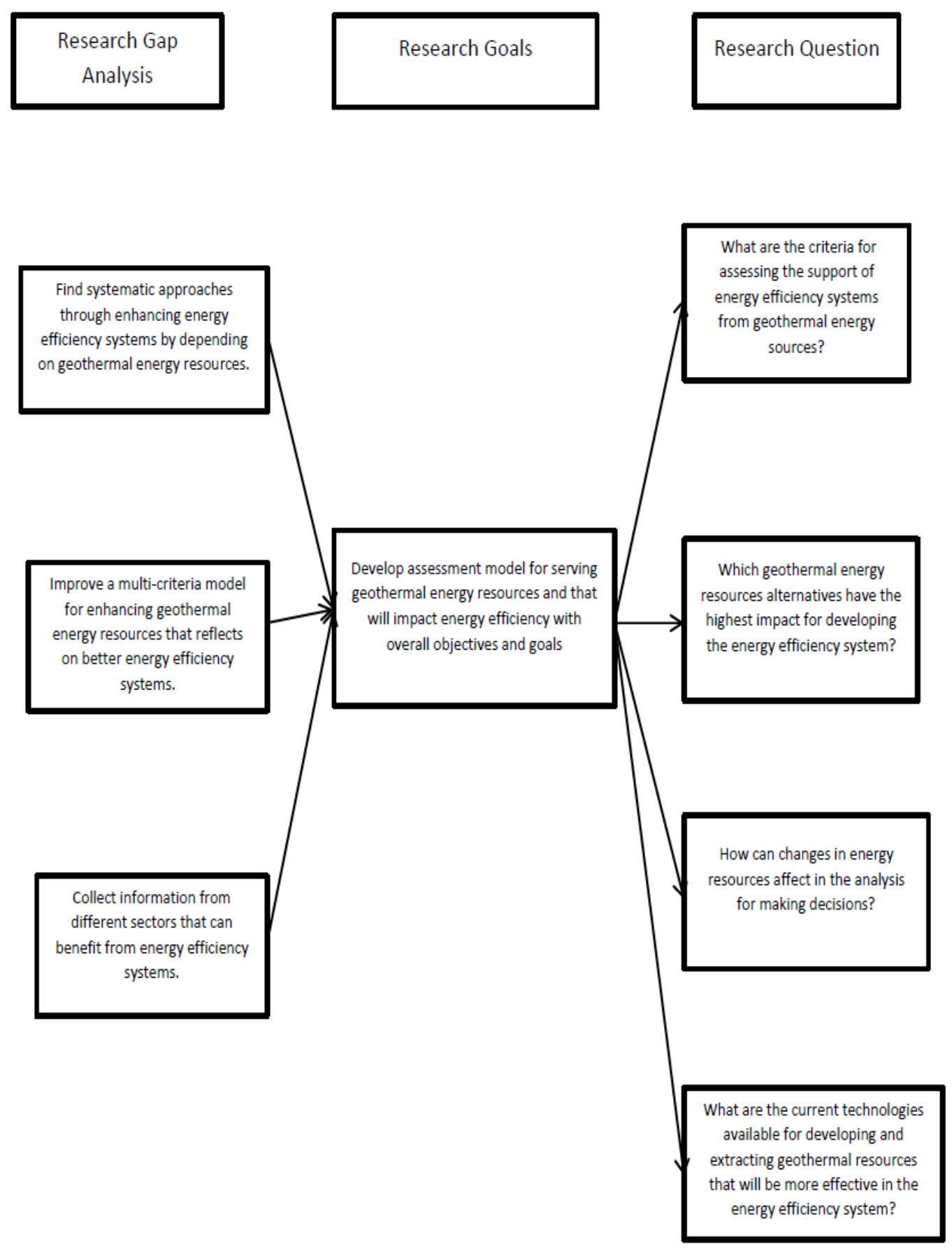


\section{CHAPTER 3: RESEARCH APPLICATION BACKGROUND}

\subsection{Importance of Geothermal Energy in Oregon}

It is very important for current and future politics focus on energy safety, energy independence, and minimizing the affect of greenhouse gas emissions. Many countries found that it's necessary to support the use of renewable energy, and they see that geothermal energy has the opportunity to be developed and to be successful. Different applications of technology principles like ground source heat pumps (GSHP), groundwater heat pumps (GWHP), are used for obtaining the best service to the community [210]. In addition, the increasing demand for energy leads to an increase in the dependence on renewable energy technology. Renewable energy is challenging in terms of how to implement this form of energy with respect to following items:

uncertainty in policy design and duration, unclear or inadequate enforcement, and targets that are too hard to reach in some cases. The challenge is to generate the motivation to create goals that will exceed uncertainty in policy design and duration, and unclear or inadequate enforcement. The 2007 Oregon's Renewable Portfolio Standard (RPS) legislative objective made it a goal to have $25 \%$ of electricity come from renewable energy by 2025, and that goal has led to exploring what options exist for renewable energy resources. The demand for electricity is expected to reach $7500 \mathrm{MW}$ by 2025 . As of 2010, the demand of energy was $5500 \mathrm{MW}$ [211].

The opportunity for success in covering a large part of the electrical system comes from renewable energy. Geothermal energy is one of the highest potential resources to reach the goal of supporting electrical system in Oregon. The report from Northwest 
Power and Conservation showed that close to $6000 \mathrm{MW}$ of wind power by 2025 will be available. Western Governors Association showed that close to $1290 \mathrm{MW}$ of geothermal, and $500 \mathrm{MW}$ of solar power by 2025 will be available. According to Daim, Kayakutlu, and Cowan, "' the $6000 \mathrm{MW}$ of wind power referred to above would only translate to about 2000 MW of constantly available power' 'in Northwest by 2025 [211]. Solar power works only in daylight, and depending on weather in Oregon, the probability to benefit from solar is approximately $15 \%$. Geothermal energy has the potential to work all the time and reach the capacity factor of $90 \%$ [211]. It is very significant to drive the motivation to use geothermal energy resources, and each driver will clarifies on the following items:

- Cost and Risk: The availability of geothermal energy resources, the knowledge of how to benefit reduces the cost of investment from the technology, and how these are reflected in different applications and minimizes the risk if a project continues over a long period of time.

- Environmental Friendliness: Geothermal energy is considered friendly to the environment since it doesn't produce carbon emissions in most of the applications that use energy that supports electrical systems.

- Increasing and Changing Electricity Demand: Geothermal energy resources in Oregon have the potential to cover a large part of the electricity demand and the systems for electrical if people know how to use the best model for obtaining a high productivity of energy. The availability of geothermal energy resources will make an impact by reducing the load on electricity. As there will be an increase in 
the load as a result from an increase in population, there is an opportunity to apply this new technology.

- Uncertainty in Fuel Prices and Growing Cost of Energy: Geothermal energy resources can have a constant price over a long period of time, and this impacts the decision making process with respect to the cost effect. Other sources of energy, like oil, don't have a constant price, and this has an effect on decision making. This uncertainty in the price creates inconsistent cost environment.

\subsubsection{Cost and Risk}

The availability of technology can impact and minimize cost. There is a reduction of cost by about $60 \%$ for application of geothermal energy resources with low temperatures before 2030. There is no constant price for the cost of geothermal energy because geothermal energy has three types: power plant, district heating, and the direct use of geothermal. The cost for each one is different than others. The cost of geothermal heating system relies on a type of loop system that can be horizontal or vertical. The estimated cost for a home with 25,000 square feet with a 120,000 BTU load for both cooling and heating ranges from between $\$ 20,000$ to $\$ 25,000$ for construction. This system minimizes utility bills by $40 \%$ to $60 \%$. This system is considered economical because the payback period is between two to ten years, and the life system for geothermal heating system is between eighteen to twenty-three years. The U.S government supports improvement for this kind of project through offering a $30 \%$ federal tax credit, and many states and companies work to have incentives for this kind of 
investment [212]. During the construction of geothermal projects there is still a high risk of failure because it is unknown where the maximum capacity of production can be reached from the drilling and where the drill must be stop. Also, the investors must invest a lot of money in the project, and they don't know when there will be a return on the investment. In contrast, oil and natural gas are profitable and investors will know when the return on the investment will be [213].

The cost of a geothermal power plant is considered economical if the impact has been studied over a long period of time because the investment cost is about two-thirds for the project and one third for the facility. The graph below shows how the investment for a long term geothermal energy project is better than other renewable energies [214]. 
Figure 3 : Levelized Cost of Selection Technologies

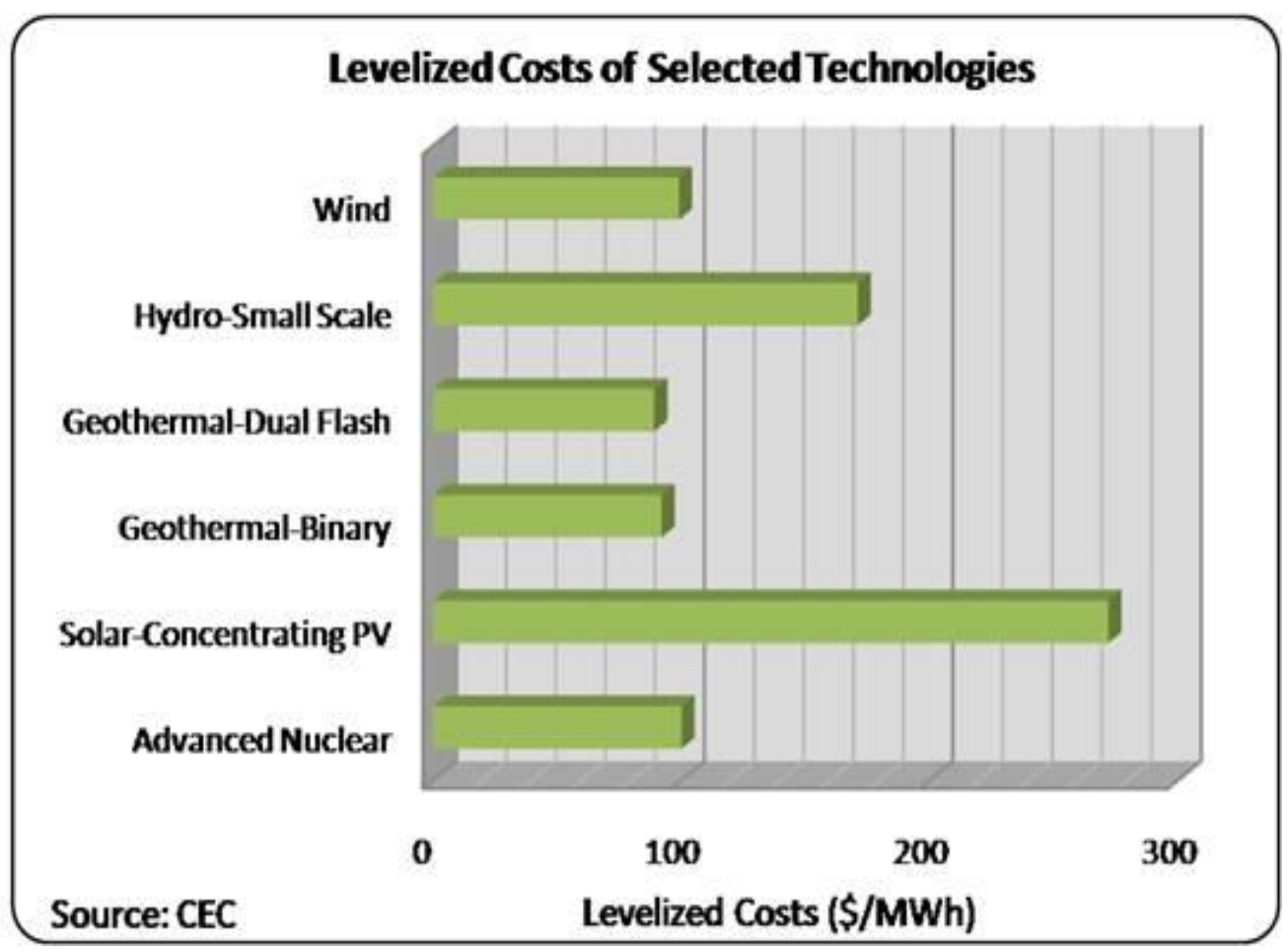

\subsubsection{Environmental Friendliness}

Geothermal energy is considered a source of sustainable energy like solar, wind, and biomass. This type of sustainable energy is defined as friendly to the environment since it releases a low emission of greenhouses gases into the atmosphere. Geothermal energy is sustainable, and has the potential for production over a long period of time with a constant level of production. The process for taking energy from geothermal sources requires withdrawing the fluid and extracting the heat content. Many parts in the world that use geothermal show no change in the production over the years. 
The application of geothermal energy for power generation and direct use will have some effect on the environment, but it still has an obligation to protect the environment according to United Nations Summits in Rio 1991, Kyoto 1997, and Johannesburg 2001. Any type of technology used for power generation requires many phases of development and production, which includes: exploration, production tests, construction, and operation. The effect on the environment must not be permanent, including: changes to landscape, land use; emissions into the atmosphere; noise; land subsidence; seismicity; and solid waste. Geothermal power generation generates a lower emission of greenhouse gases than other technologies, and geothermal power plants generate lower $\mathrm{CO}_{2}$ emissions than other technologies. It is clear that geothermal power plants are better for the environment than power plants that require oil, coal, or gas [215]. In Oregon, the type of geothermal power plant is a binary plant, and it is considered friendly to the environment because all of the processes occur in a closed system. The graph below shows how the importance of geothermal energy to reduce the heat loss, and why a binary power plant is the best type of power plant. 
Figure 4: Using Types of Energy in the Electric Power

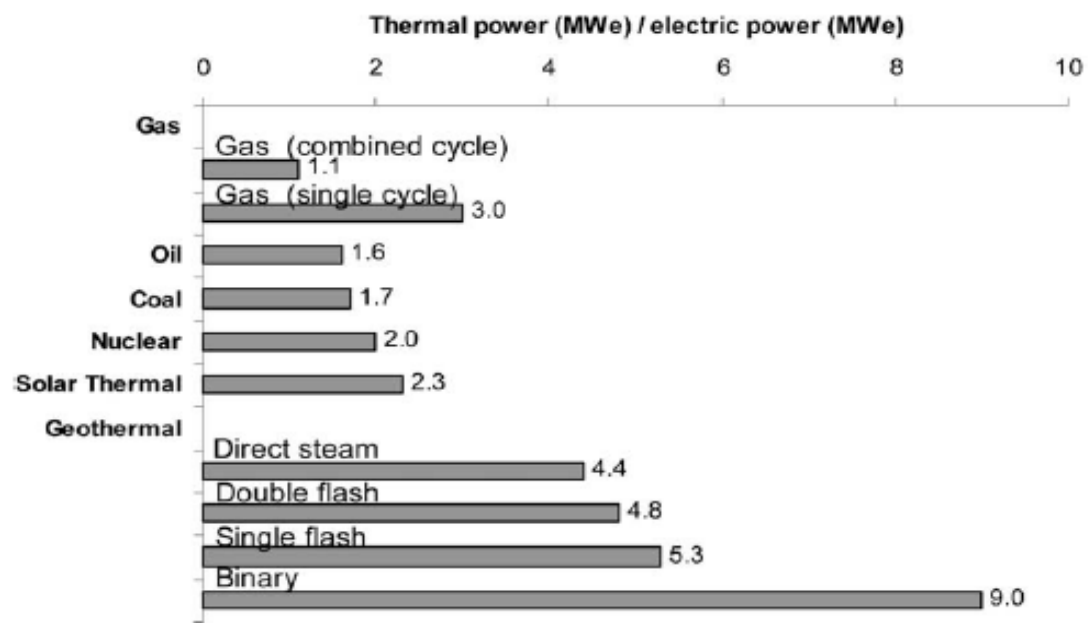

The direct use application of geothermal energy has less impact on the environment than a power plant. The figure below shows the probability of occurrence and the potential effect on the environment.

Figure 5: Impact of Geothermal Energy Resource on the Environment

Potential environmental impacts of direct use geothermal projects; probability and severity (Lunis, 1989)a

\begin{tabular}{lcc}
\hline Impact & Probability of occurring $^{\mathrm{b}}$ & Severity of consequences $^{\mathrm{b}}$ \\
\hline Air pollution & $\mathrm{L}$ & $\mathrm{M}$ \\
Surface water pollution & $\mathrm{M}$ & $\mathrm{M}$ \\
Underground pollution & $\mathrm{L}$ & $\mathrm{M}$ \\
Land subsidence & $\mathrm{L}$ & $\mathrm{L}$ to M \\
High noise levels & $\mathrm{H}$ & L to M \\
Well blowouts & $\mathrm{L}$ & L to M \\
Conflicts with cultural and archeological features & $\mathrm{L}$ to M & M to H \\
Socioeconomic problems & $\mathrm{L}$ & $\mathrm{L}$ \\
Solid waste disposal & $\mathrm{M}$ & $\mathrm{M}$ to H \\
\hline
\end{tabular}

${ }^{a}$ Pollution can be chemical and/or thermal.

${ }^{\text {b }} \mathrm{L}=$ low; $\mathrm{M}=$ medium; $\mathrm{H}=$ high. 


\subsubsection{Increasing and Changing Electricity Demand}

The demand for electricity changed in the last thirty years in the Pacific Northwest, and that has changed because of many factors like the price of consumption energy, increasing human population, and construction of new projects as an opportunity to use new technology. All of these factors have contributed to this change in demand, and this change will continue and increase in the future [216]. Geothermal energy will reduce the load on the electricity system.

\subsubsection{Increasing Population and Impact on Electrical System}

The population growth in Oregon has increased in the last three years since 2014. Population increased in Oregon by $1.1 \%$ or by 43,690 people. According to Burchard, "This is up from the 2013 growth rate of 0.9 percent and higher than the 2014 nationwide growth rate of 0.7 percent'"[217]. The increase in population growth is different from the past. The population increased from 2,927,800 in 1991 to 3,962,710 in 2014, and during this time period the rate increased by $10.7 \%$, which was more than the national growth rate $8.6 \%$ [217].

Population growth has an impact on the electrical system since the electrical system covers a limited number of people and homes. The growth in population requires the expansion and building of new houses to support the rising population, and this requires a preplan for the electrical system. A plan for a new electrical system needs to identify the future energy capacity to make the plan appropriate for an increasing population. The availability of geothermal energy resources will have positive impact on 
rising populations in parts of Oregon, and will contribute to the reduction of demand on the electrical system.

\subsubsection{The Construction of New Projects for the Opportunity to Use New Technology}

A residential energy consumption survey from the U.S. Department of Energy found that every house has the equipment or a device for space heating. More than three quarters of homes have air-conditioning, and most of these homes use both a heating and cooling system during the year. Heating and cooling systems don't have the same source of energy, types of appliances, or distribution systems, and they have a different impact on the environment [218]-[219]. In addition, the increase in population leads to new projects that cover for the lack of energy. This has an impact on the use of new technology and the understanding of how it works to best serve the population increase. North America has problems supplying electricity during a peak seasons like summer, which results from adding new appliances with capacity loads adding to the currently constant loads like commercial lighting and industrial processes. These new appliances require additional resources of energy, which leads to many problems, such as: an increase in the cost, a switch in peak capacity generators, and ways to minimize the demand. There will be blackouts when the supply of electricity is not enough for demand for electricity. Therefore, it helps to have several pricing programs to adjust for problems like time- of- use, critical peak pricing, real time pricing, and peak time rebate. These programs help to increase the knowledge to decide which strategy is more important for lowering peak-time electricity use [220]. The availability of geothermal energy resources 
will reduce the load on the energy system, and decrease the import of energy resources while at the same time an increased dependence on geothermal energy resources will match the increasing demand for new projects.

\subsubsection{Constant Prices Over the Long Term}

Oil and energy prices have not been constant since the oil crisis in 1973, and there are many factors that have contributed to the increased fluctuation in these prices. Research studies showed that $95 \%$ of crude oil, refined petroleum, and natural gas products do not show consistency in terms of cost. A recent study showed that the price for crude oil is more variable than about $65 \%$ of other products [221]. From the research study it is clear that crude oil products will not generate a consistent price over a long period of time. On the other hand, geothermal energy resources have constant prices over the long term, and this helps accurate decision making about what is the requirement of geothermal energy for development.

The price of geothermal heat is considered constant, and this encourages customers to support geothermal heating projects. In addition, geothermal energy is better than tradition fuel like coal, lignite, and fuel-oil because it has low initial operation costs and a low selling price [222]. The reason that geothermal energy prices are constant as compared to oil, gas, and natural gas is because geothermal energy resources don't require the large amount of fuel imported from sources outside of Oregon to operate. Although the initial investment for the construction of geothermal power plants is high until the completion of the construction, the size of production and capacity for generating electricity will lead to a modification in the price over the long term [213]. 
The constant price will help decision makers decided which factors are necessary for improvement the production phase, and whether to keep the price the same or to modify the price to make it suitable for the process of production.

\subsection{Potential of Geothermal Energy}

There is a lot of research developed to enhance the ability of geothermal energy globally. The Geothermal Energy Association (GEA) data showed a large improvement in geothermal projects by adding twenty-one new power plants in 2014 , which helped to support the electrical grid by adding approximately $610 \mathrm{MW}$. This improvement in the electric grid was a large change to add more power plants in 2014 in one year compared with 1997. In addition, the global market increased by about $12.8 \mathrm{GW}$ to include forty countries. The data showing that the capacity of the global geothermal industry can increase between $14.5 \mathrm{GW}$ and $17.6 \mathrm{GW}$ by 2020 . The probability of reaching $27-30 \mathrm{GW}$ by the beginning of 2030 will occur if all countries work to achieve the goal and target of geothermal power development. Forty countries now work to cover the lack of electricity through geothermal power. According to geologic knowledge and technology, communities and countries benefit from 6.5 of total global potential of geothermal power. This knowledge and technology showed that in 2005 more than 160 global geothermal projects were installed adding $4 \mathrm{GW}$ to the electric grid [223].The figure below shows the progress of geothermal power. 
Figure 6: International Geothermal Power Nameplate Capacity (MW)

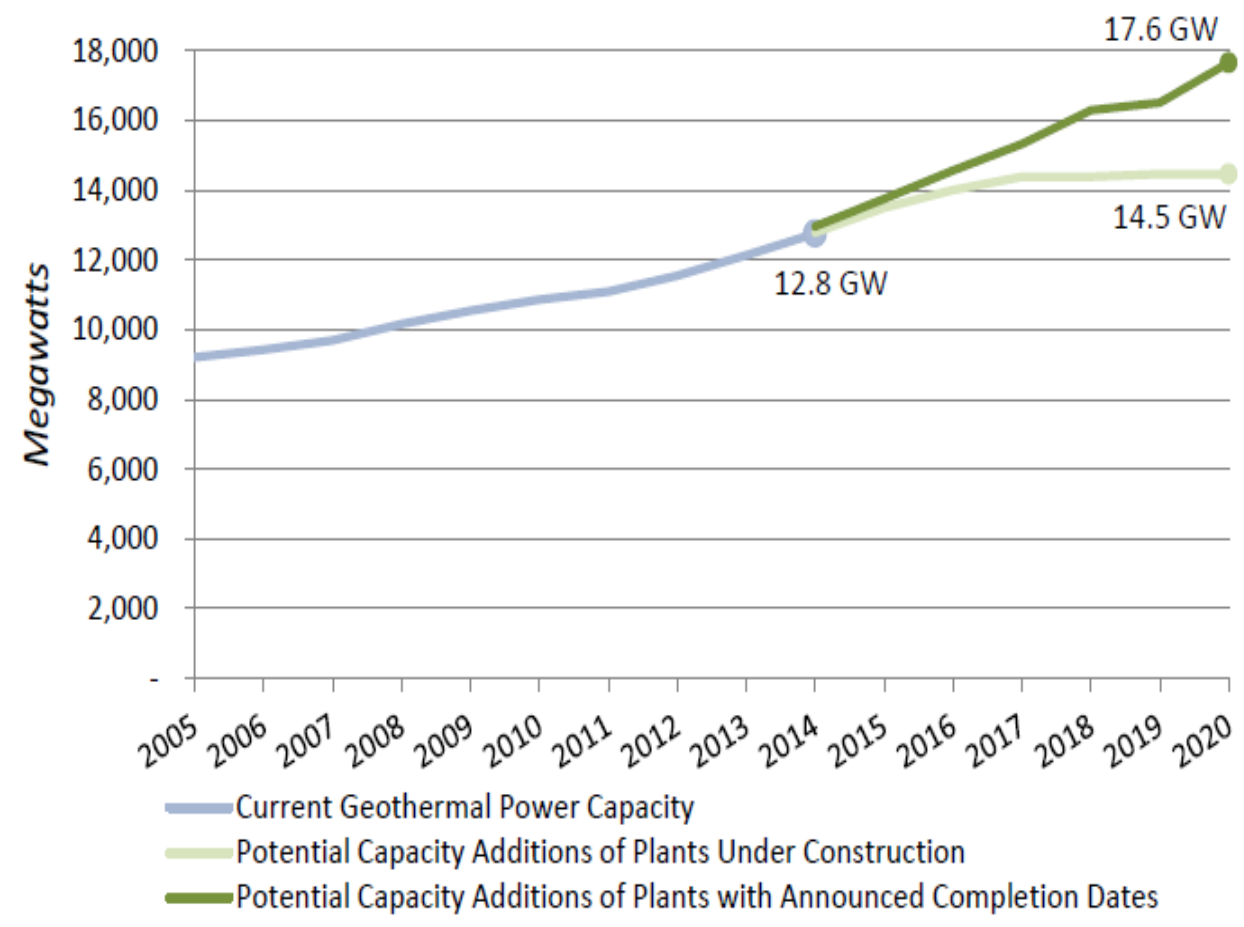

Many countries have set goals and targets for future geothermal power use.

The figure below clarifies the goal for each country and the year they will reach the target. 
Figure 7: Important Geothermal Markets Announced Planned Capacity Additions \& Targets

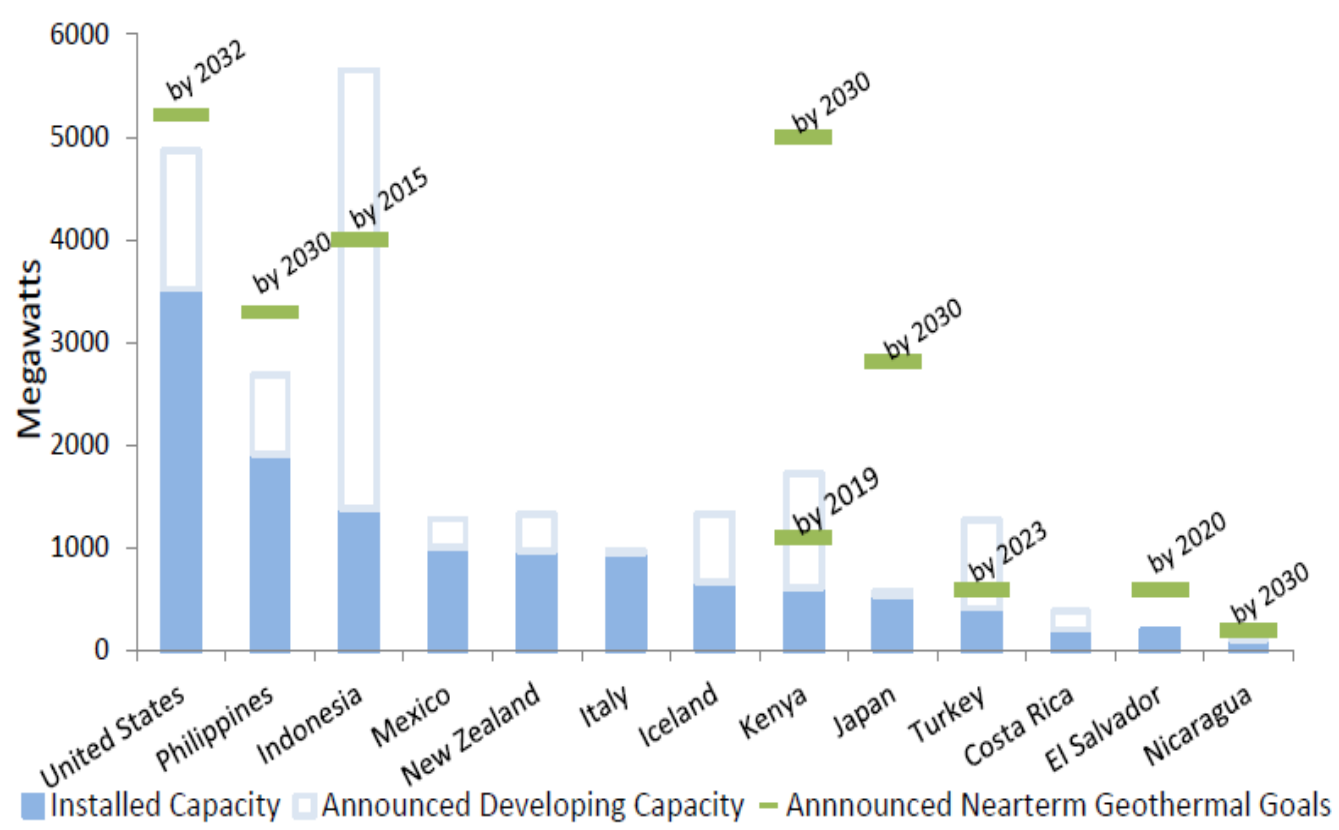

According to GEA research, new geothermal projects are planned for the near future. Compared to other countries in the world, the U.S. dominates the market in the installation of geothermal power plants. The figure below clarifies established geothermal power markets installation capacity. 
Figure 8: Established Geothermal Power Markets Installed Capacity (MW)

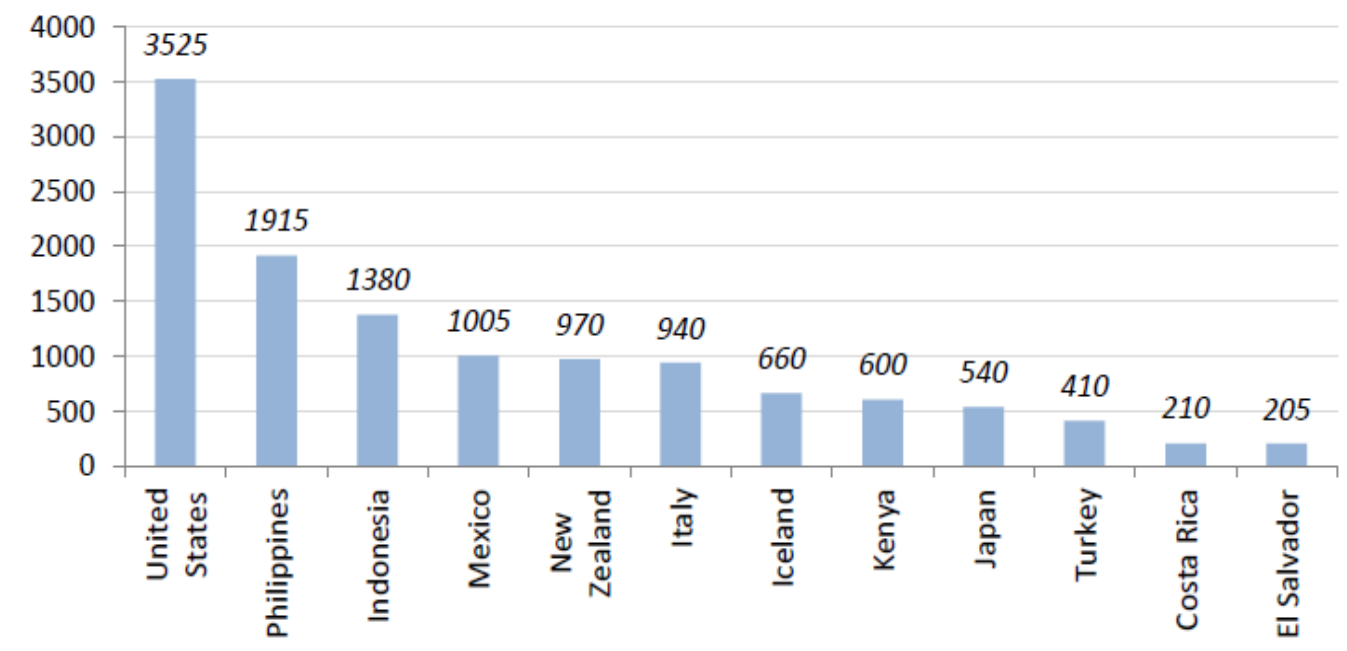

In the U.S., attention has been paid to the benefits from the potential use of geothermal energy, and there have been large improvements for obtaining the best service and support to the electric grid. By the end of 2014, the U.S. succeeded in installing a net capacity of about $2.7 \mathrm{GW}$ to the grid. The size of production from geothermal power under development is $1,250 \mathrm{MW}$, and there still is a $500 \mathrm{MW}$ delay in the service because geothermal power is waiting for the agreement of power purchase. Many projects were developed after 2005, and these improvements represented the addition of thirty-eight geothermal power projects, which have contributed to have 700 MW to the electric grid [223].

The figure below clarifies the improvement of geothermal projects in the U.S. 
Figure 9: U.S. Industry Geothermal Nameplate \& Net Capacity

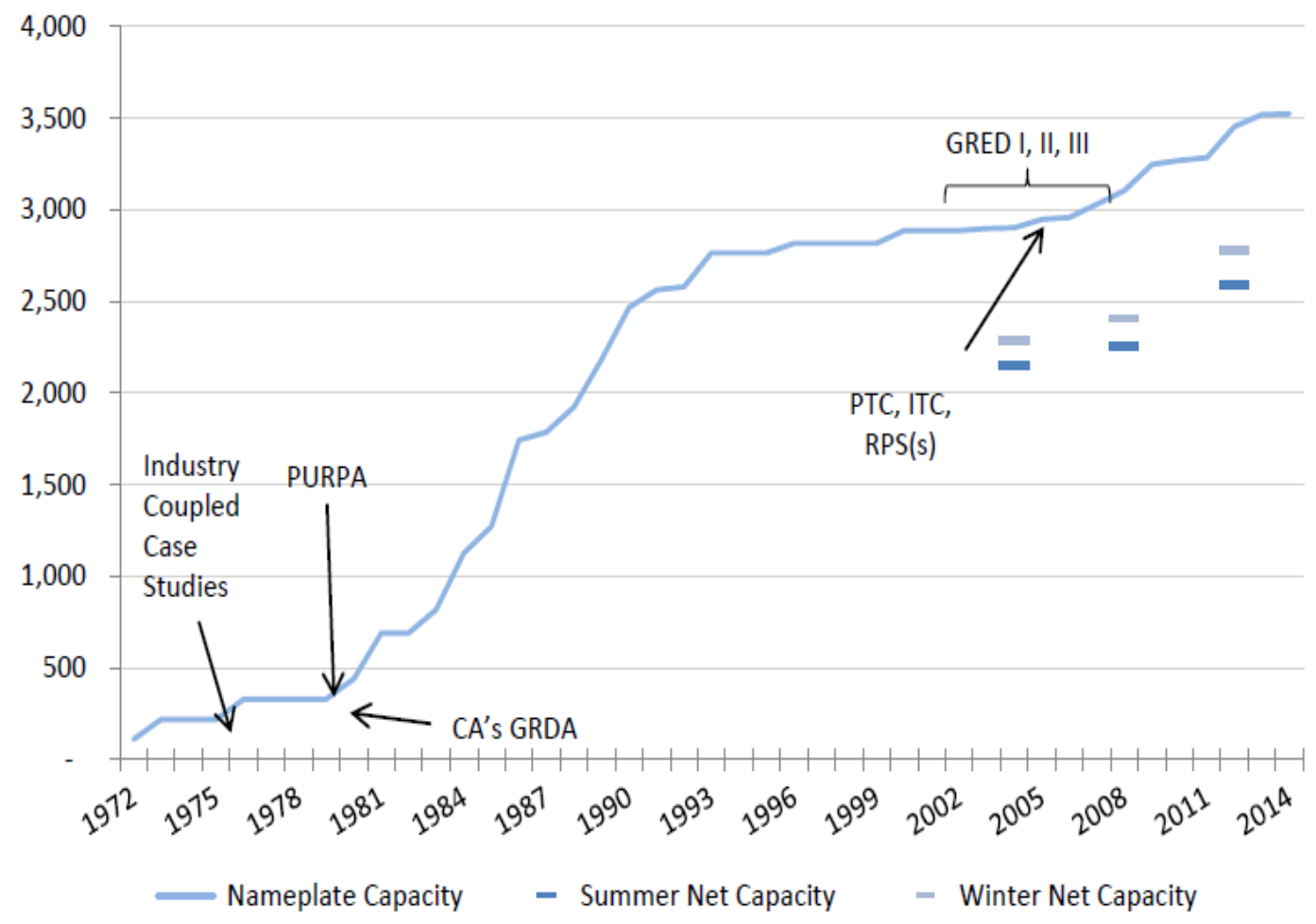

\subsubsection{Developing Projects}

The amount of developing geothermal projects is different from state to state in the U.S, and that because of many reasons. Many companies made recommendations to the GEA, noting that it isn't a good time to invest in federal or state leasing on on-site locations since it there isn't an economic benefit. These companies will reinvest in the future when the market has more opportunity to invest in geothermal projects. The main reason to consider geothermal energy is that it is more economical than other renewable energy sources like solar and wind, and it can replace for oil, and gas. Geothermal resources require equipment for discovery, drilling, and extracting, which carries a large financial cost. It is important to invest in the project over the long term for the project to 
be economical, which sometimes requires putting the project on hold, and reinvesting at a later date when the conditions and policies in the market change [223]. The figure below clarifies the distribution of geothermal energy projects in different states, and the probability of success according to market conditions and policies.

Figure 10: Developing Planned Capacity Additions \& Nameplate Capacity by State

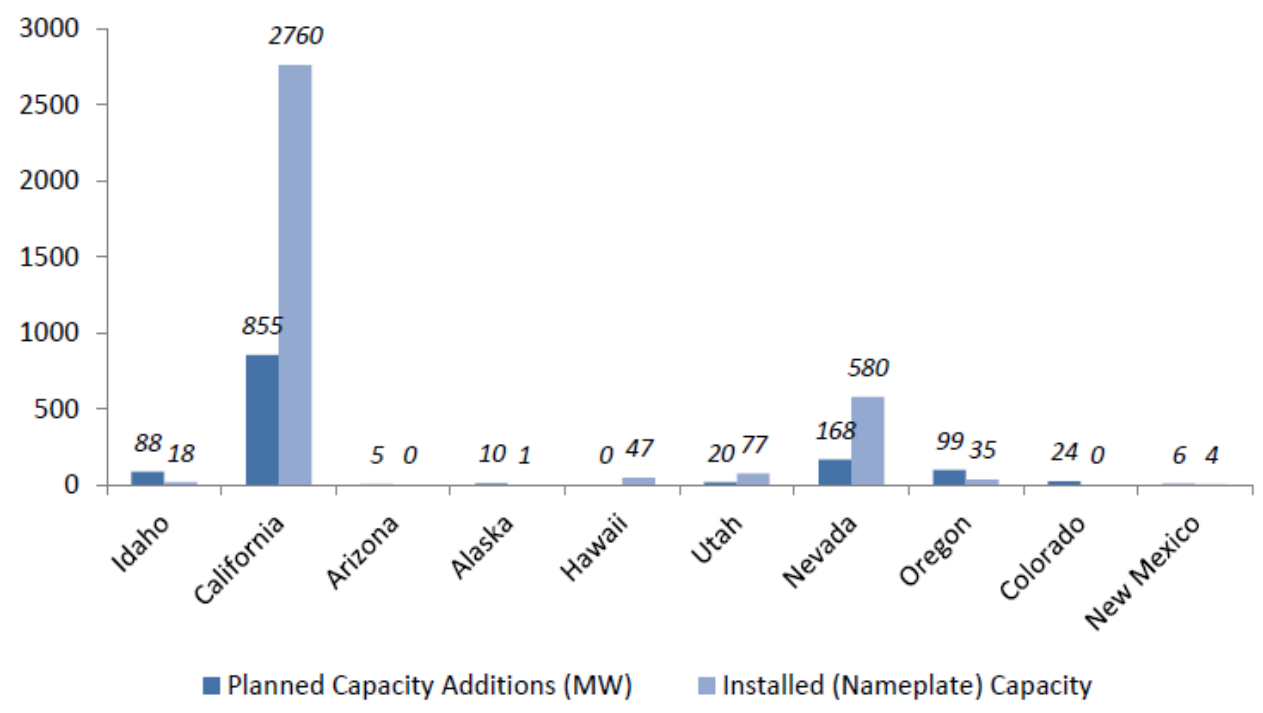

Figure 11: Number of Developing Projects by State

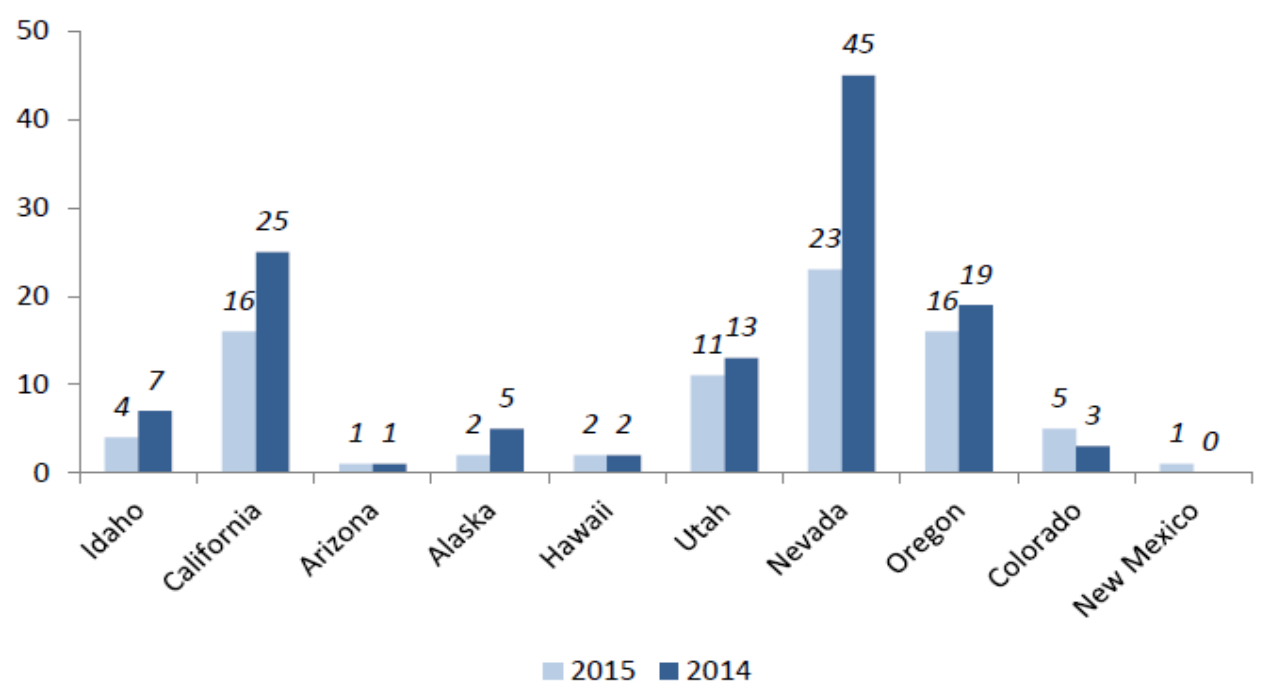




\subsubsection{Global Technology and Manufacturing Development}

There are three types of geothermal power technology: dry steam, flash, and binary. Each technology specifically works with one kind of geothermal energy source. Each resource requires a drilling depth in the earth different from other resources because each depth different temperature. Flash and dry steam technology are more developed than binary since both flash and dry work with high temperatures, which produces higher energy. The percentages for using flash, dry, and binary are 58\%, 26\%, and 15\% respectively. The remaining $1 \%$ is used for back pressure and other types of geothermal technologies [223]. The figure below clarifies the progress for using different types of technology during the period 1990-2014.

Figure 12: Operating Capacity by Technology Type

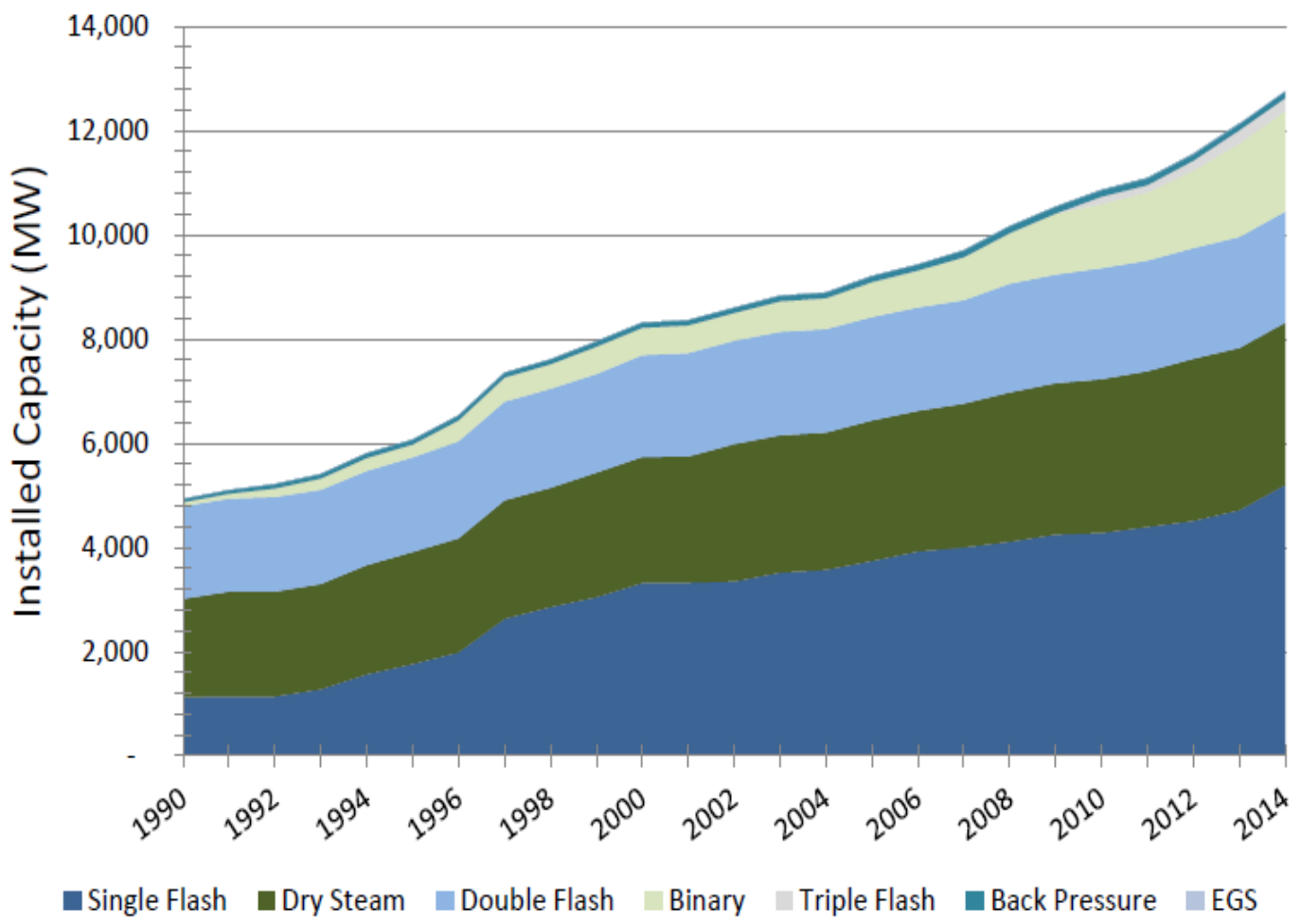


Besides the improvement of global technology, manufacturing also has improved as more companies participated in geothermal energy. The geothermal turbine market contains many companies that supply equipment for working in high temperature projects like: Toshiba, Mitsubishi, and Fuji. The low temperature Organic Rankine Cycle (ORC) contains one manufacturer, Ormat Technologies Inc. (ORA). Many smaller companies are beginning to contribute to the geothermal market. For example, Ormat manufactures geothermal turbines, and covers about $85 \%$ of the ORC market. Electra Therm is considered unique for the design for co-produced fluids geothermal facilities [223]. The figures below clarify the data with the equipment supply for geothermal power projects.

Figure 13: Major Geothermal Equipment Suppliers Megawatts Operating and Project Count

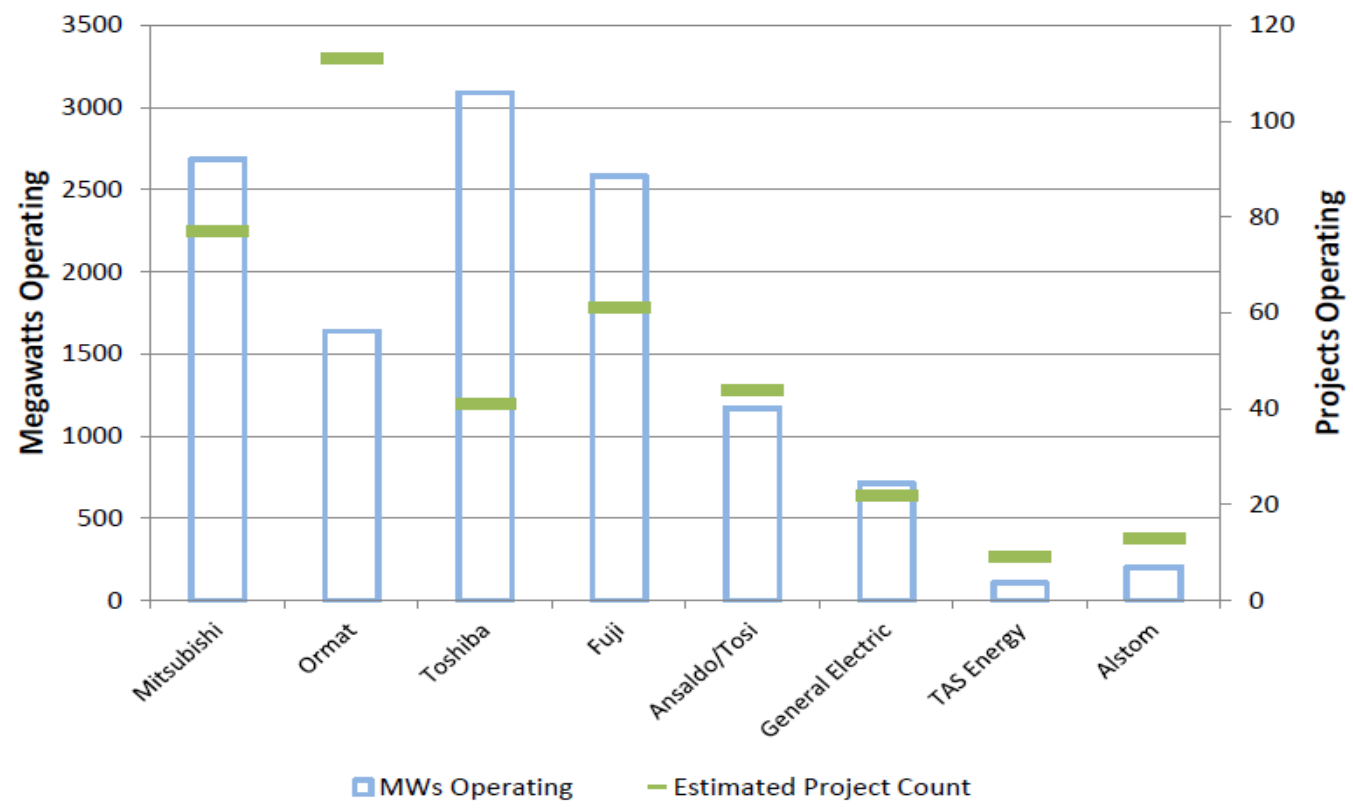


Figure 14: Geothermal Equipment Suppliers as Percent of Global Market by Projects

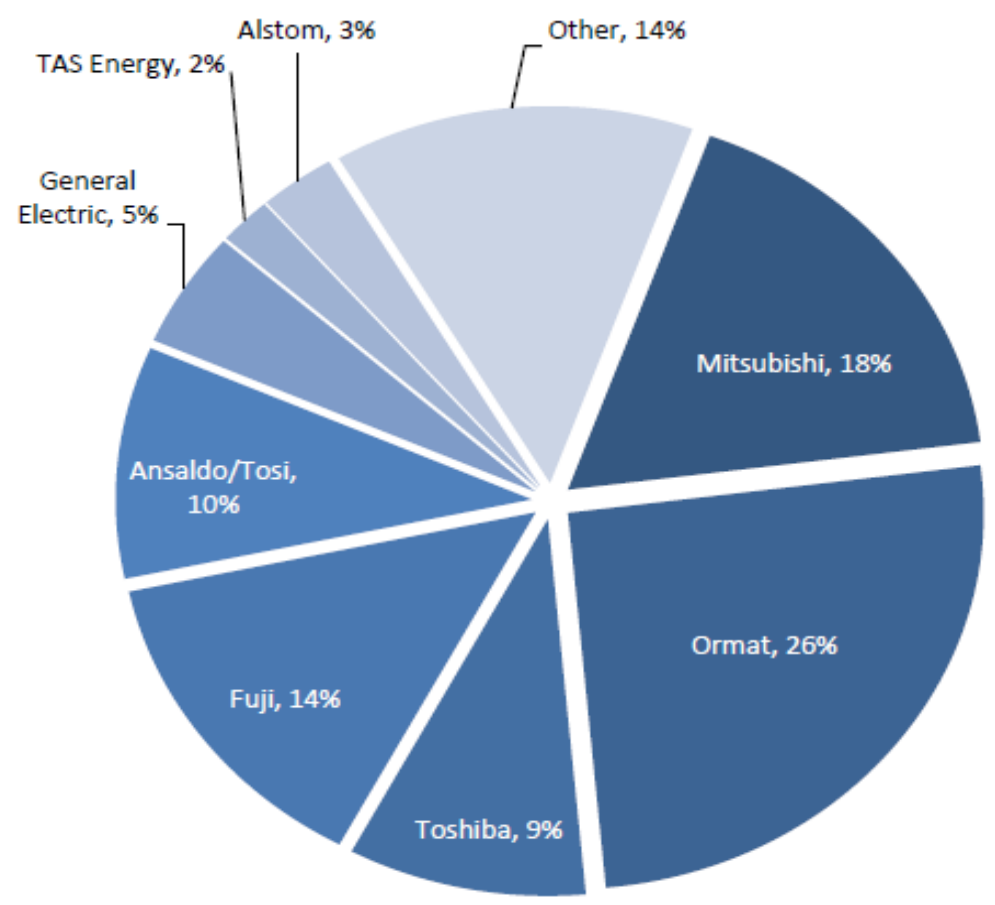

Figure 15: Geothermal Equipment Suppliers as Percent of Global Market by MW

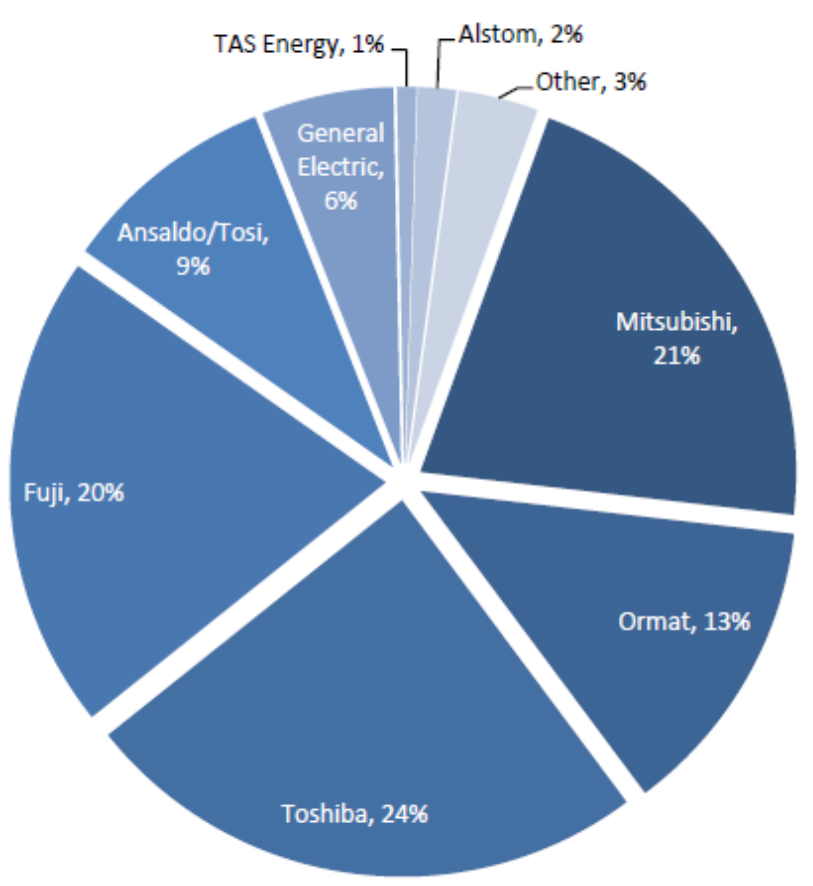




\section{CHAPTER 4: RESEARCH APPROACH AND METHODOLOGY}

\subsection{Introduction}

As our project was extensive, and reaching a final decision for improvement of geothermal energy was complex, the best method to use was the Analytical Hierarchy Process (AHP). In addition, this method depends on taking surveys from an expert panels and analyzing their knowledge in Hierarchical Decision Model (HDM). Also, we chose expert panels who have diversity of knowledge in their field, and have the ability to make a decision without looking at the problem from one side. This method identifies each level and evaluates the important action in the final decision [224].

Many developments for the model of decision making happened after using the Analytic Hierarchy Process method (AHP) created by Thomas L.Saaty in the 1970s, and it is acceptable in different scientific communities to solve complicated decisions from technical and environment standpoints [143]-[144]. Also, this method facilitates the long decision process by dividing the information into smaller elements to make the decision easier [145]. In addition, the pair-wise comparison helps in making decisions, and Saaty specifies the use of the 1-9 scale measurement and eigenvector [145]. While Kocaoglu specifies the use of 100 points between each pair [146]. The 100 points are more convenient than the 1-9 scale because experts have more flexibility to determine between 100 points while 1-9 scale isn't as flexible [225]. The AHP model has been used in a lot of studies, and it was used as a basis for data in more than 1000 journal articles and 100 doctoral dissertations [144]. 
The Research Institute for Sustainable Energy (RISE) in the Engineering and Technology Management Department at Portland State University has successfully made a comprehensive framework to evaluate energy technology and renewable energy by assessing technical, social, political, environmental, and economic criteria. By using these criteria, the Hierarchical Decision Making (HDM) method will help the decision making process for selecting geothermal energy resources that impact and support electrical systems in Oregon.

\subsection{Research Objective}

The objective for the research study is to find the assessment model framework that can best be used to support electrical in Oregon by developing geothermal energy sources. The research study works through collaboration utility objectives and goals for filling the present gap that is available, and works to create a solution by generating a comprehensive decision- making process to evaluate the best course of action. MCDM is suitable tool to use for the decision- making process. This approach will help to evaluate various decision options that includes a diversity of users, and reduces the uncertainty associated with the decision [30]-[32]. Overall, the research model will increase knowledge about how to develop geothermal energy sources that will support electrical in Oregon including minimizing uncertainties, understanding the potential applications in different areas inside Oregon, and finding the optimum way to reach the goal of best course of action. 


\subsection{Research Methodology}

The purpose of the research study is to improve the model framework for reaching the potential of electrical, and to expand the model by depending on utility objectives and goals more than on just quantifying variables. Using this approach will help to account for user heterogeneity and will minimize the uncertainty generated from this variable. The result will be an increased knowledge and accuracy about simplifying electrical technology evaluation and planning approaches, which will lead to a better understanding of how to make the best choice in decision-making process.

Decision alternatives in the research model are geothermal energy resources. Every geothermal energy resource alternative consists of different technology, and each one has a different purpose from the other geothermal energy resources. But every geothermal energy resource supports and reduces the load on the electrical system. Using different kinds of knowledge leads to increased information about the research study, and then reduces the uncertainty that will happen if they depend on one or two sources of obtaining information. Overall, the research model will give more knowledge to the geothermal field through understanding the problem, finding suitable solutions, and minimizing the uncertainty with respect to all utility objectives and goals.

Levels of Research Methodology Consist of Many Major Phases:

\subsubsection{Hierarchical Decision Model (HDM)}

\subsubsection{Stage 2: Judgment Quantification}




\subsubsection{Stage 3: Data Collection}

\subsubsection{Stage 4: Data Analysis}

\subsubsection{Hierarchical Decision Model (HDM)}

This model is considered a part of the research project aspect of the Research Institute for Sustainable Energy in the Department of Engineering and Technology Management, and HDM supplies a multi perspective assessment of various energy technologies such as nuclear, wave, geothermal, biomass, petroleum, hydro, wind, solar, biofuel, coal, synfuels, hydrogen, and conservation. The HDM method will clarify the problem, and help to decide which decision is most suitable for solving the research problem since most people don't have the ability to solve the complicated process of decision-making without dividing the problem into small parts, which helps to make the right decision with respect to objectives, goals, and criteria. In addition, HDM has ability to observe a large number of alternatives, and can analyze the alternatives from different angles. This process of analysis will help to look at the problem in depth and then choose the most suitable decision. HDM methodology is successfully used in different applications like the development of hydrogen energy technology [226], risk analysis in energy policy [227], national emerging technology strategy [228], solar energy technology [229], and long-term improvements in the national electrical [230].

HDM is a good approach for obtaining the best decisions in geothermal energy resource alternatives. In this research, HDM will break the decision into smaller elements through communication between the mission, objectives, goals, and alternatives. The 
figure below clarifies the general framework for RISE, which is use in the Department of Engineering and Technology Management at Portland State University.

Figure 16: RISE Research Model

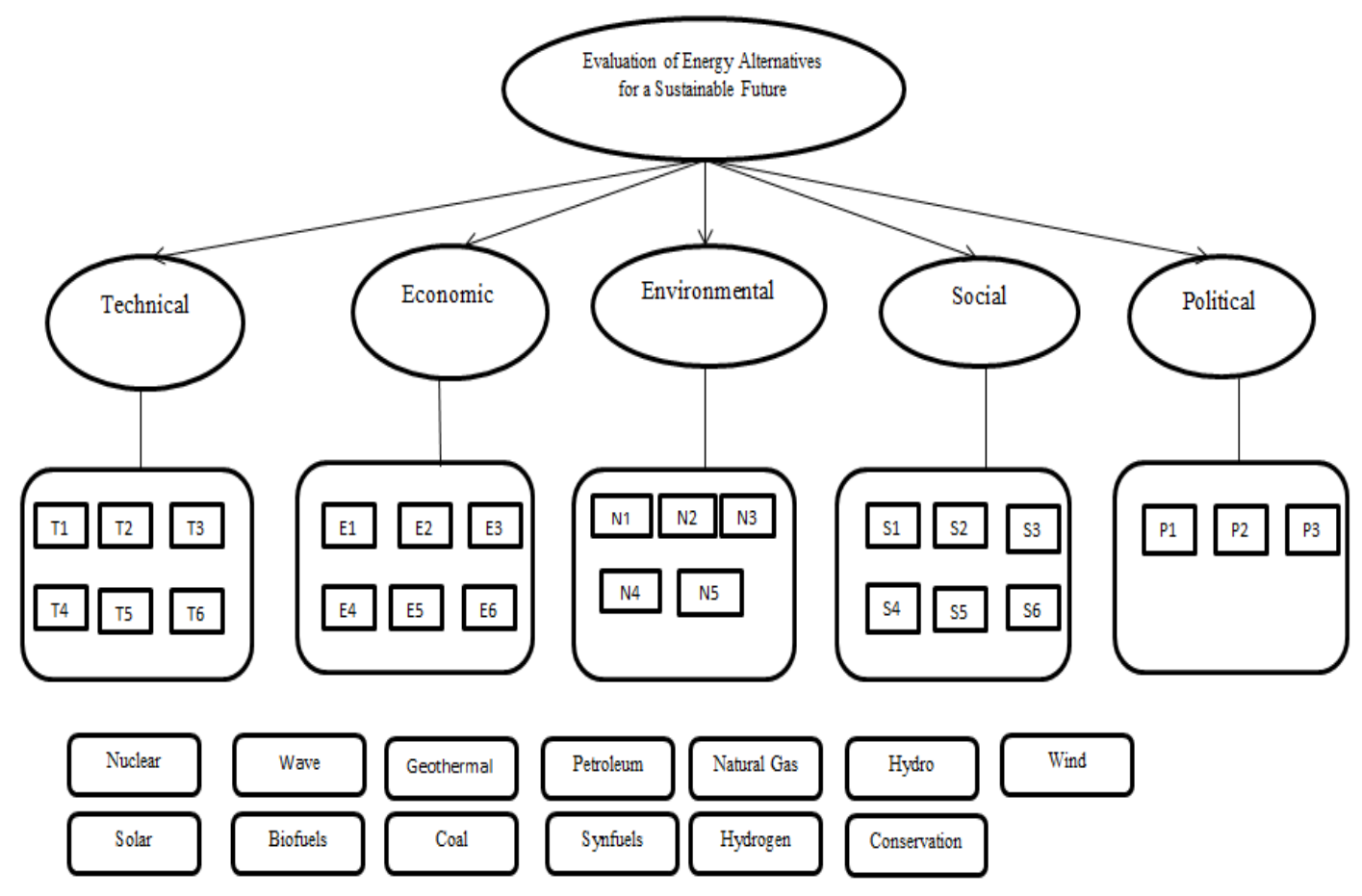

Dundar Kocaoglu, PI

Tugrul U. Daim, Co-PI

Intensive literature review was read for the evaluation of geothermal energy resources. The literature review showed that different types of utility work under geothermal energy resources. The table below clarifies the evaluation of geothermal energy resources from the literature review. 
Table 6: Evaluation of Geothermal Energy Resource from the Literature Review

\begin{tabular}{|c|c|c|c|}
\hline Perspectives & Objectives & Goals & Reference \\
\hline \multirow{3}{*}{ Social } & \multirow{3}{*}{$\begin{array}{c}\text { Encourage } \\
\text { Community to } \\
\text { Support Geothermal } \\
\text { Energy Project }\end{array}$} & $\begin{array}{c}\text { Create New Jobs } \\
\text { Opportunity }\end{array}$ & $\begin{array}{c}231][170][232]- \\
{[236]}\end{array}$ \\
\hline & & & \\
\hline & & Social Acceptance & [237]-[239] \\
\hline \multirow{4}{*}{ Environmental } & \multirow{4}{*}{$\begin{array}{c}\text { Minimize } \\
\text { Environment Impact }\end{array}$} & GHG Emission & $\begin{array}{c}231]-[232][240]- \\
{[244]}\end{array}$ \\
\hline & & Land Requirement & {$[231][245]-[248]$} \\
\hline & & Seismic Activity & {$[231][249]-[253]$} \\
\hline & & $\begin{array}{l}\text { Using the Land for } \\
\text { Other Purposes }\end{array}$ & [231] \\
\hline \multirow{3}{*}{ Economic } & \multirow{3}{*}{$\begin{array}{l}\text { Reduce Expense of } \\
\text { Investment Energy } \\
\text { Projects }\end{array}$} & $\begin{array}{l}\text { Minimize Capital } \\
\text { Cost }\end{array}$ & [254]-[259] \\
\hline & & $\begin{array}{c}\text { Minimize Operation } \\
\text { Cost }\end{array}$ & {$[231][260]-[264]$} \\
\hline & & Economic Boost & [265-266] \\
\hline \multirow{3}{*}{ Technical } & \multirow{3}{*}{$\begin{array}{l}\text { Technical Options } \\
\text { Improvement for } \\
\text { Geothermal Energy } \\
\text { Projects }\end{array}$} & $\begin{array}{l}\text { Minimizing the } \\
\text { Demand of Critical } \\
\text { Resources }\end{array}$ & [267]-[274] \\
\hline & & $\begin{array}{l}\text { Increasing the } \\
\text { Capacity of the } \\
\text { Energy System }\end{array}$ & [275]-[281] \\
\hline & & $\begin{array}{c}\text { Equipment } \\
\text { Manufacturing } \\
\text { Development }\end{array}$ & [282]-[286] \\
\hline \multirow[b]{2}{*}{ Political } & \multirow{2}{*}{$\begin{array}{l}\text { Minimize the } \\
\text { Negative Impact on } \\
\text { the General Public }\end{array}$} & $\begin{array}{l}\text { Minimizing Noise } \\
\text { and Odor }\end{array}$ & [287]-[291] \\
\hline & & $\begin{array}{l}\text { Minimizing Property } \\
\text { Damage for } \\
\text { Reducing the Impact } \\
\text { on Life Style }\end{array}$ & [292]-[296] \\
\hline
\end{tabular}


From the literature review, this research is divided into four levels:

\subsubsection{Mission Statement}

\subsubsection{Utility Objectives Level}

\subsubsection{Utility Goals Level}

\subsubsection{Alternatives Level}


Figure 17: Hierarchical Decision Model for the Research Model

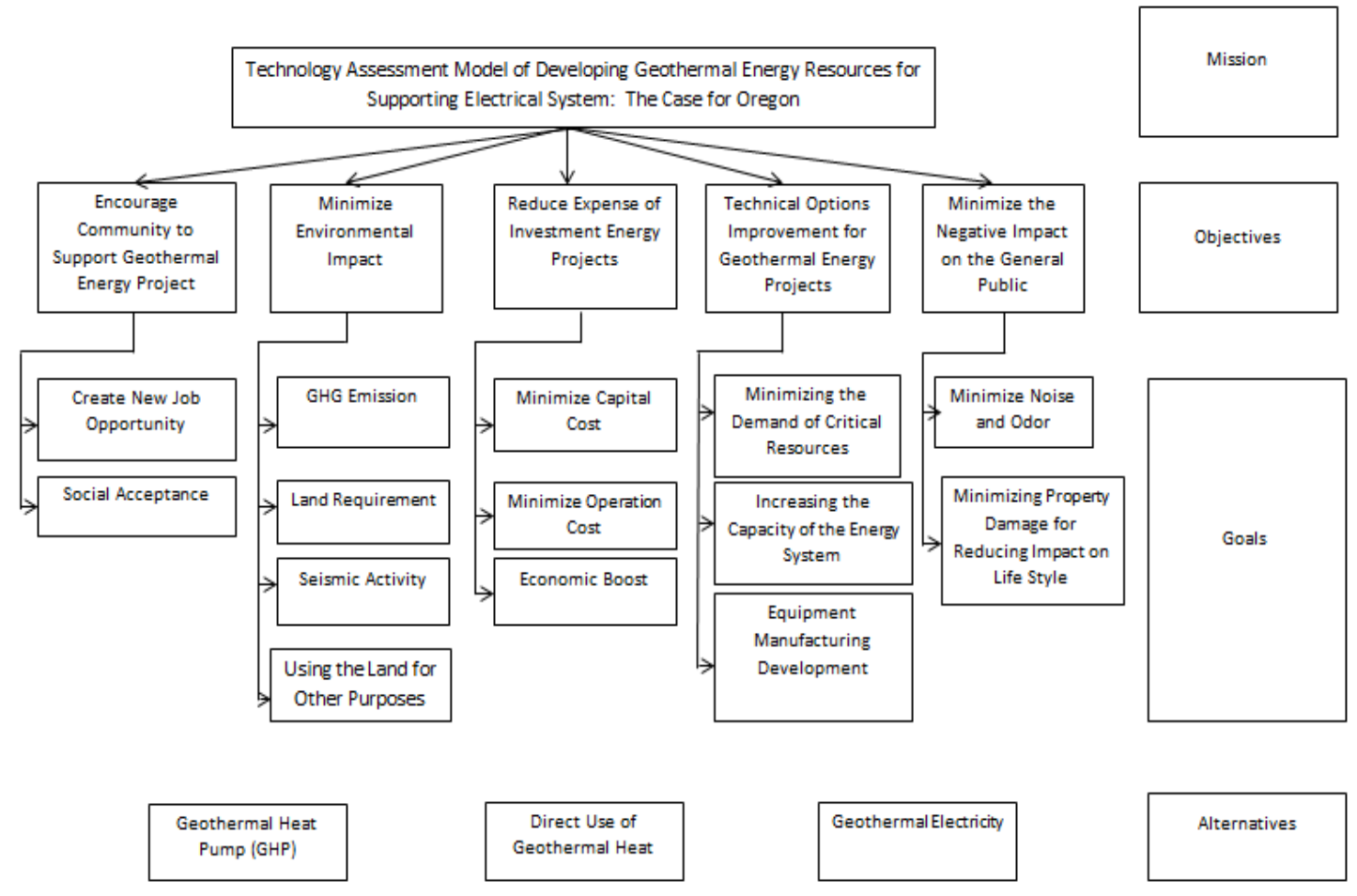




\subsubsection{Mission Statement}

The purpose of using this methodology is to determine the alternative uses for geothermal energy development that have a high value in terms of overall objectives and goals of the utilities.

\subsubsection{Assessment Variable of Utility Objectives Level}

The role and responsibilities for the objective level is clarified in the following sections:

- Encourage Community to Support Geothermal Energy Project: Using geothermal energy project will make future customer life easier and more convenient, that will encourage customer support for geothermal project, and that will increase the adoption and development in this field. The availability of geothermal projects is necessary for supporting the general public and the job sector with more improvement in the operation it compares with other sources of energy.

- Minimize Environmental Impact: Pollution increases from the expanding the demand for energy in different sectors, which effects the environment through effecting greenhouse emissions. The availability of geothermal energy will have positive impact on the environment since it doesn't consume a huge amount of fuel as compared with other sources of energy, so it will reduce GHG emissions. In addition, it is possible to drill from one geothermal energy source site and reach other geothermal energy source-sites. This has a positive impact on the environment because it reduces the drilling to one site and doesn't effect on other 
sites, and the earth can be used for other purposes. Also, it is possible to create a beautiful landscape in the surrounding areas of geothermal energy sources without creating a negative impact on the wildlife.

- Reduce Expense of Investment Energy Projects: Increasing population creates challenges to keep-up with the demand for energy without blacking out the system. In addition, the size of the financial investment is still large, and the operations of expenses are still very high. Although the investment in geothermal energy projects is not considered competitive as compared with other energy sources, the different technologies that accompany geothermal energy resources will change that if more attention and effort are given to this area of alternative energy. The availability of geothermal energy, and the knowledge of how to use the resources effectively lead to less dependence on resources from outside state.

- Technical Option Improvement for Geothermal Energy Projects: It is important to understand the technical systems for improving the benefits from geothermal energy. The increasing the demand of energy has a negative impact in some areas because not all resources of energy will be enough to cover the demand in the electrical system. Up until recently, some of the challenges facing this alternative energy source were understanding the concept of geothermal power and its effectiveness without negatively impacting other factors like the environment and the economy. There is the possibility to develop the process in the future by quickly responding to any changes in the market and in the requirements of customers. The ability to have the flexibility to work in any 
situation with different factors is a key factor for improving geothermal energy projects.

- Minimize the Negative Impact on Public: The initiation of geothermal resources projects accompanied by creating a transition line between traditional energy sources and geothermal sources is required for producing energy that supports the electrical system, they also have an impact on public life style and the health system for a community through minimizing demand on the use of traditional power plants and that reduces the level of pollution. Although the impact of geothermal power plants on the environment is initially less than power plants for other energy sources, it is important to take into consideration any negative impact on the environment and general public, and work to reduce this impact. The objective of reducing the negative impact on the general public and public spaces is to ensure that these geothermal projects don't interact with other projects in the same area because this can lead to conflict. Knowing how to deal with different kinds of projects in the same area is important and has less negative impact on the public.

\subsubsection{Assessment Variable of Utility Goals Level}

The role and responsibilities for each goal level are clarified in the following sections. Geothermal energy resources will be evaluated according to the potential for each goal.

\subsection{Encourage Community to Support Geothermal Energy Project: The} utility objectives can be divided into the following utility goals. 
- Create New Job Opportunity: Geothermal energy has social implications because it has a large effect on economic development and employment opportunities. When a geothermal power plant is installed, it requires a diversity of skills to complete the construction. This process leads to create indirect jobs, more economic activity, and increased tax revenue. Having a geothermal power plant will create a diversity of job opportunities ranging from exploration and drilling jobs to high-tech manufacturing jobs such as the manufacturing of generators, turbines, and power conditioning components to maintenance jobs in the power plant itself. These additional jobs and income will support industry employment through local and regional economy. The production of geothermal energy in the U.S is $\$ 1.5$ billion/yr. Garman showed that in 1996 there was close to 12,300 direct jobs and 22,700 indirect jobs in the U.S. The electricity sector requires the employment of 10,000 people for the installation and the operation of systems in power plants. [231]. This process for creating new job opportunities can work in Oregon and be successful if people know how to benefit from the source of geothermal energy. Many articles show the potential to have new jobs from geothermal energy [170][232]-[236].

- Social Acceptance: In 2006, the BLM managed about 350 geothermal leases, of which 55 were producing geothermal energy from 34 power plants [237]. In 2009, President Obama announced a new energy plan for the U.S. The goal from this plan was to increase renewable energy $10 \%$ by 2012 and $25 \%$ by 2025 . The continual commitment to expand and improve federal lands for the use of 
geothermal resources has led to an increase in production, and in 2012 his goal was exceeded by $2 \%$, therefore the probability of reaching the $25 \%$ by 2025 will be high [238].

The benefit from geothermal energy is to supply a baseload power and to benefit local economies. Direct use application and power plants lead construction, operations, and maintenance jobs. The power plants also produce tax revenue for federal, tribal, state, and local governments [239].

4.3.1.3.2 Minimize Environmental Impact: the utility objectives can be divided into the following utility goals.

- GHG Emission: Geothermal direct use has less effect on the environment as compared with geothermal power plants. This type is beneficial for states, local communities, agribusinesses, and other industries that require these resources. Also, this type supports the environment since it contains lower levels of gases than the higher temperature fluids. Most applications of geothermal direct use today work through closed- loop, emission free system. The carbon dioxide that accompanies geothermal fluids has an advantage to greenhouse application because carbon dioxide is important for growth the plants. According to Garman, "Geothermally heated livestock facilities make waste management and collection easier for farmers and ranchers. The geothermal water can be used directly for cleaning and sanitizing these facilities, as well as drying the waste" [231]. This concept can work in Oregon. Many articles show the importance of reducing GHG emissions when using geothermal energy resources [232] [240]-[244]. 
- Land Requirement: Geothermal fields require one to eight acres per megawatt (MW) while nuclear operations need five to ten acres, and coal operations need nineteen acres. Coal power plants need a huge area of land that is used for agricultural purposes for making their fuel. This process for making fuel leads to the movement of earth, which contributes the creation of tunnels, waste heaps, and open pits. The process for re-treating the land is complicated and expensive [231].

Geothermal power plants need wells, which require to drilling into the ground. The process of drilling will effect the land, but with the advance in the equipment of drilling there is less impact on the land. This drilling technology allows several wells to be drilled from one location, and this reduces the impact on the land, access roads, and geothermal fluid piping. A good example of drilling technology is slimhole drilling, which has 4" to 6 " diameter well while the traditional has a diameter of 8 " to 12 ". Slimhole drilling also minimizes the land used for site preparation and road construction [231]. Many articles show the importance of using geothermal energy resources for keeping land from negative impact of projects [245]-[248].

- Seismic Activity: There are benefits from using one location drilling technology where they can also drill several wells from this one location, which land use. Even so, land subsidence is the effect that occurs during the drilling process whereby there is the extraction of a large amount of fluid: water, oil, and geothermal fluid) from underground the land. The common solution for geothermal power plants is to inject spent geothermal fluids back into a reservoir 
to avoid subsidence. When they inject the spent resources, the earth will be stable from any subsidence [231]. Many articles show the importance of injecting fluid in geothermal site to avoid occurring seismic [249]-[253].

The probability of seismicity occurrence or earthquake activity will be very high when a large amount of geothermal fluids are withdrawn and injected below the earth surface. The areas with a high frequency of naturally occurring seismic events will be the most affected by the operation of geothermal power plants. If seismic activity occurs, it will be less than magnitude 2.5 on the Richter scale (earthquakes usually cannot be felt under 3.5). In Geysers, California, areas with geothermal fluids have experienced seismic activity [231]. Research studies found that the probability of seismic activity will be high where the location for power plant requires deep drilling (long distance under the surface of the ground), which is what clearly happen in Geysers, California. In Oregon, research studies found that all power plants are binary plants, which do not require the same deep drilling as the location requires in California.

- Using the Land for Other Purposes: Geothermal power plants are found in beautiful natural environments, and the power plants don't affect the landscape because of many factors: geothermal power plants have a small footprint since they don't require a large amount of land as compared with other sources of energy like coal and nuclear power plants [231].

The impact of minimal land use leads geothermal power plants to mix harmoniously with a diversity of other land uses. That means that when the activity of a power plant is 
completed, the land can be re-treated and used for livestock grazing or other agriculture purposes. In California, the Imperial Valley hosts fifteen geothermal power plants that make $400 \mathrm{MW}$ of electricity, and at the same time it keeps one of most productive agriculture areas in the world. According to Garman, " one geothermal power plant from the fifteen plants at Salton Sea is neighbor to a national wildlife refuge that shelters hundreds of animal species"' [231]. A visitor in this area will not notice anything strange in the landscape even though a geothermal power plant is hosted in this location. This makes a suitable siting for injection and production wells, which reduces the negative impact for both scenic and recreational attractions [231]. This type of operation can work in Oregon since it was successful in another area like California. The figure below clarifies the probability and severity of potential environment impacts for geothermal energy resources.

Figure 18: The Impact of Geothermal Energy on Different Factors in the Environment

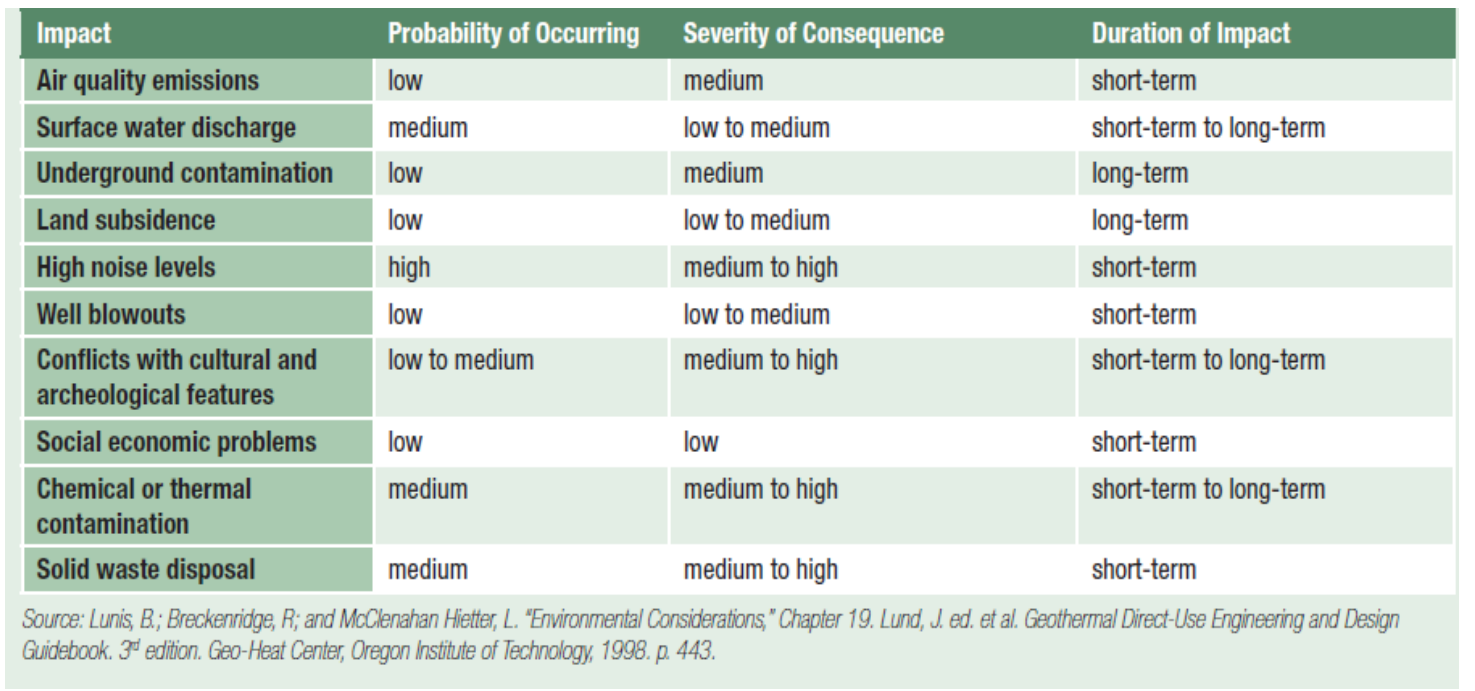


4.3.1.3.3 Reduce Expense of Investment Energy Projects: The utility objectives can be divided into the following utility goals.

- Minimize Capital Cost: One of the challenges to take into consideration is the ability to have a good investment that has potential to cover the requirements of the electric grid without harm and high initial capital cost. Projects of geothermal energy resources have the potential to reduce the cost of financial investments if the investment is taken over a long period, and where the results from these projects will be clear. Geothermal energy resources are very important in supporting the national economy because this leads to a reduced dependence on imported resources like oil. Almost half of the U.S. annual trade deficit will be erased when the U.S. begins to depend on domestic resources and reduces the dependence on imported oil. Research studies show that there is a potential to benefit from the international market for geothermal energy to enhance domestic economic health, and that in the next twenty years foreign countries will begin to invest $\$ 25$ to $\$ 40$ billion for the construction geothermal power plants. Many states in the U.S. now are looking for the best way to benefit from geothermal energy. The geothermal power plants in Nevada generate approximately 240 MW of electricity, which saves energy from imported sources by 800,000 tons of coal or three million barrels each year. The plants paid $\$ 800,000$ in 1993 for county taxes and \$1.7 million in property taxes. The U.S Bureau of Land Management also benefited from the lease of the land, which contributed the increased tax revenue, which contributed to $\$ 20$ million each year in rent and royalties from 
geothermal power plants [231]. This process can be successful in Oregon after making some adjustments to fit with the energy policies in Oregon. Many articles show the opportunity of geothermal energy resources to reduce dependence on traditional energy [254]-[259].

- Minimize Operation Cost: Research studies showed the economic impact of geothermal development projects in Siskiyou, Modoc, and Shasta counties in California and Klamath County in Oregon. These projects contribute to an increase of $\$ 114$ million on the 30-year life span of the projects, which is reflected by an increase in local income and job opportunities through creating new construction and in the operation of the power plants [231].

The Geothermal Energy Association found that California has the potential to develop geothermal energy since it has a lot of support. In the short-term, geothermal energy can make from 300 to $600 \mathrm{MW}$, and can reach up to $1000 \mathrm{MW}$ when they enhance three locations: the Salton Sea, Northern California, and the Geysers area north of San Francisco, and the total from these locations will be 3600 MW if they know how to fully use and benefit from the technology available today. The Geothermal Resources Council lists the importance of geothermal sitings for development, and the companies that can do this operation [231].This process can be successful in Oregon if researchers put their efforts into reaching best way to do this process. Many articles show the potential of geothermal energy increasing in the future [260]-[264].The table below clarifies Induced Geothermal Employment Renewable Portfolio Standard (RPS) in California. 
Figure 19: Impact the Operation of Geothermal Project on the Employment

\begin{tabular}{|c|c|}
\hline $\begin{array}{l}\text { Construction } \\
\text { Employment for } \\
\text { International Market }\end{array}$ & $\begin{array}{l}800 \text { person/ } \\
\text { years }\end{array}$ \\
\hline $\begin{array}{l}\text { Construction } \\
\text { Employment for } \\
\text { In-State Market }\end{array}$ & $\begin{array}{l}1,230 \text { person/ } \\
\text { years }\end{array}$ \\
\hline $\begin{array}{l}\text { Operating } \\
\text { Employment for In- } \\
\text { State Market }\end{array}$ & $\begin{array}{l}59,030 \text { person/ } \\
\text { years }\end{array}$ \\
\hline TOTAL & $\begin{array}{l}61,060 \text { person' } \\
\text { years }\end{array}$ \\
\hline \multicolumn{2}{|c|}{ 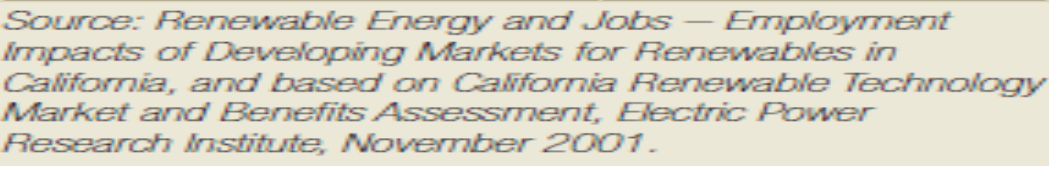 } \\
\hline
\end{tabular}

- Economy Boost: Geothermal projects have the potential to enhance the economies through increased tax revenues, the creation of new businesses and local jobs, and enhanced community involvement. Many articles show the importance of geothermal energy to enhance economic[265]-[266].

\subsection{Technical Option Improvement for Geothermal Energy Projects: The} utility objectives can be divided into the following utility goals.

- Minimizing the demand of Critical Resources: The increase in human population has led to an increased demand on critical resources like oil, water, coal, etc. Over time, it has been observed that there are many challenges with these increases since the cost of these resources has risen, which has affected different sectors like social, environment, and economic. Continuing to use these resources without looking to find alternative solutions is a large problem, and it will have a negative impact on all aspects of society and the environment. [267][274]. The availability of geothermal energy resources is important to cover and 
reduce the dependence on critical resources, such as oil, natural gas, coal, etc. It is important to know how to find the best methods for the maximum benefit of geothermal energy resources.

- Increasing the Capacity of the Energy System: The availability of geothermal energy resources will minimize the load on the electrical system and simplify the challenges associated with increased energy load, especially during peak periods of demand of electricity like severe winter and summer periods. There are many applications of geothermal energy resources, which can support the electrical system since geothermal energy covers large areas like bathing and swimming, agriculture, the industrial process, snow melting and cooling [275], electrical systems [276]-[278], and large buildings [279]-[281]. The diversity of different applications and the increased capacity of geothermal energy resources is significant in supporting the electrical system and in avoiding blackouts during peak demand period.

- Equipment Manufacturing Development: Even though the variety of variable geothermal energy equipment in the market, but it still need more development to increase the geothermal electrical, and for that it will need to develop the technologies that use in manufacturing of the equipment. It is important for increasing the capacity of electrical systems to make new development of equipment manufacturing. The increase in population living in different areas will create more demand for energy, so the construction of new projects like geothermal energy resources will require the development of equipment 
manufacturing. Many articles show the importance of equipment manufacturing development on the energy system [282]-[286].

\subsection{Minimize the Negative Impact on the General Public: The utility}

objectives can be divided into the following utility goals.

- Minimizing Noise and Odor: It is important for the success of geothermal energy projects that geothermal energy resources work without negatively impacting the general public by avoiding and reducing noise and odor as quickly as possible. If the geothermal energy industry has the ability to deal with and avoid both noise and odor, there will be more support for these projects. Many articles show the importance to construct projects without annoying the public [287]-[291].

- Minimizing Property Damage for Reducing the Impact on Life Style: The construction of new projects creates new transmission lines for connecting with the energy system. These connections will change the pathways, which will require redrawing new paths for residents and commercial activities. The construction of new projects will disturb movements of the general public and local businesses, so it is necessary in the construction of geothermal energy projects to build the plant in the right place. With the installation of new projects it is important to avoid any conflicts or obstacles to the movement of residential and commercial activities. Many articles show the importance of building new projects without disturbing the activities of the general public and local businesses [292]-[296]. 


\subsubsection{Geothermal Energy Resources Alternatives}

To gain the best support from the electrical system in Oregon, it is important to simplify geothermal energy resources and to benefit from the application of technology. Research studies show that geothermal energy resources can be simplified by the application of technology in three different ways: Geothermal electricity, direct use of geothermal heat, and geothermal heating pumps. Each application is clarified in the following sections:

\subsection{Geothermal Electricity}

This type of technology produces electricity through depending on the heat that comes from the water inside of the Earth. This method brings the sources of geothermal energy to the surface by drilling in wells of different depths, and then converting the extracted heat from the Earth into electricity. There are three different types of power plants that produce electricity: flash, dry steam, and binary power plants. These plants process geothermal resources by taking the hot water and steam from the Earth, and converting it to electricity before returning the water back to the Earth[17][297]-[299].

\subsection{Flash Power Plant}

This type of plant depends on geothermal fluid that has temperature of more than $360^{\circ} \mathrm{F}\left(182^{\circ} \mathrm{C}\right)$ to produce electricity. The plant uses steam vapor to run the turbine, and if the fluid temperature decreases, the process will be repeated to obtain more energy [300][301].This type of power plant is used in areas such as China and the Philippines [19][302]-[305]. 


\subsection{Dry Steam Power Plant}

This type of plant depends on the steam that is available below the Earth, which goes directly into the turbine to produce electricity. This type of power plant is very old and has been used in Italy since 1904 [300]. Today, steam power technology is available in many areas. The largest location, with twenty plants, that uses this type of technology to produce electricity is at Geysers in Northern California [306]-[307].

\subsection{Binary Power Plant}

This type of plant depends on a geothermal area that has a moderate water temperature of less than $400^{\circ} \mathrm{F}$, from which it produces electricity. The process of operation works through the transference of heat from hot geothermal fluid to a secondary fluid with a much lower boiling point temperature by using a heat exchanger. This creates flash water that becomes a vapor, which runs the turbine. This type of plant is better for the environment because the process takes place in a closed loop system. In the future, most of the geothermal power plants construct will be binary plants [299]. This type of plant is used in many areas like Nevada, Idaho, and New Zealand [308][313]. There is the potential to increase the use of the binary power plant in Oregon, but so far the Oregon Institute of Technology in Klamath Falls is the only place that has the ability to run this type of power plant [314]-[315]. Many projects were constructed, and in Malheur County the possibility of a successful binary power plant was high because the area has a temperature between $311^{\circ} \mathrm{F}$ to $320^{\circ} \mathrm{F}$, which encouraged the development of geothermal energy. By 2014, this temperature increased to $368^{\circ} \mathrm{F}$ because of the use of geothermal technologies [316]. 


\subsection{Direct Use of Geothermal Heat}

This type of technology uses the heat directly from the Earth without taking support from power plants and heating pumps. Geothermal resources use water that has a variation of temperature from low to moderate $\left(68^{\circ} \mathrm{F}\right.$ to $\left.302^{\circ} \mathrm{F}\right)$ [317].It is used in many applications like space heating and cooling, food preparation, spas and hot spring bathing, greenhouses, industrial business, and agriculture. There are many sectors that use direct heating from geothermal resources in many locations in the U. S. There is a capacity of about $470 \mathrm{MW}$ in direct use technology [297]. In addition, it is considered cheap energy as compared with traditional energy because it reduces the cost by $80 \%$ as comparing with fossil fuel. This energy is very clean and doesn't affect the environment. This type of energy is very successful in the ten Western states of the U.S. that use this type of energy, as was found from a survey of more than 9,000 thermal wells and springs. From the 9,000, 900 of these wells and springs have a low to moderate temperature, which is suitable for direct use of geothermal heating. The Office of Energy Efficiency \& Renewable Energy (EERE) supports the operation of geothermal energy processes at the Geo-Heat Center at the Oregon Institute of Technology in Klamath Falls, Oregon, and provides information to students and faculty [318].This type of technology can be applied in many areas like Romans in the past, such as in Belgium, and in Pompeii and Tuscany in Italy [297][319]-[320].

\subsection{Geothermal Heat Pump (GHPs)}

This type of technology works when the temperature is constant between $10 \mathrm{ft}$. and $300 \mathrm{ft}$ under the Earth. Also, there are no limitations to using this technology because 
it can use in everywhere in the world because it doesn't need drilling and rock excavation equipment for extracting the resources from the Earth. It uses covered pipes under the Earth that circulate water or other liquids, and it can be designed using different shapes like horizontal or vertical. This system is considered environmentally successful as it is suitable for both heating and cooling system. For cooling in the summer, it takes the heat from the building by using a pipe loop to exchange the heat with the Earth, and in the winter the process is reversed. This type of energy minimizes power use by $30-60 \%$ as compared with traditional equipment that consume a large amount of electricity in heating and cooling buildings [296][316] . In the U.S. there are nearly 50,000 geothermal heat pumps constructed each year, and there are two kinds of geothermal heat pump systems - the closed and the open loop systems [321]-[322]. The closed loop system includes the "horizontal" (This type of construction is very efficient for residential usage, and it works with a depth of four feet), the "vertical" (This type of construction works with large commercial buildings and schools, and it works at a depth between 100 to 400 feet), and the "pond/lake" (This type of construction works in a location that has enough body of water. The cost will be low, and it needs a depth of 8 feet to protect from freezing) [323]. The open loop system depends on wells, and works like a heat exchange by circulating the water from the ground, to the heating/cooling system, and then back into the ground. This system works with clean water [323]. In Oregon, all applications using the geothermal heat pump work with closed loop system. The open loop system does not qualify to use [324]. 
These types can be used in different applications for residential and commercial buildings. The best type to use depends on many factors like weather, the situation of the soil, the available land, and the cost of installation at the location [323].

\subsubsection{Stage 2: Judgment Quantification}

This level depends on the quantification of expert judgments for data collection purposes. The performance of expert judgment must have the ability to make a hierarchy of decisions on different levels. The procedure for judgment quantification is divided into four steps

- Mission (what business do we want to be in)

- Objective (what achievements should we have in order to satisfy our mission)

- Goals (what are the targets to reach in order to fulfill our objectives)

- Alternative (what projects should we have in order to development)

The graph below clarifies the relationship between each step. 
Figure 20: Relationship between Each Step

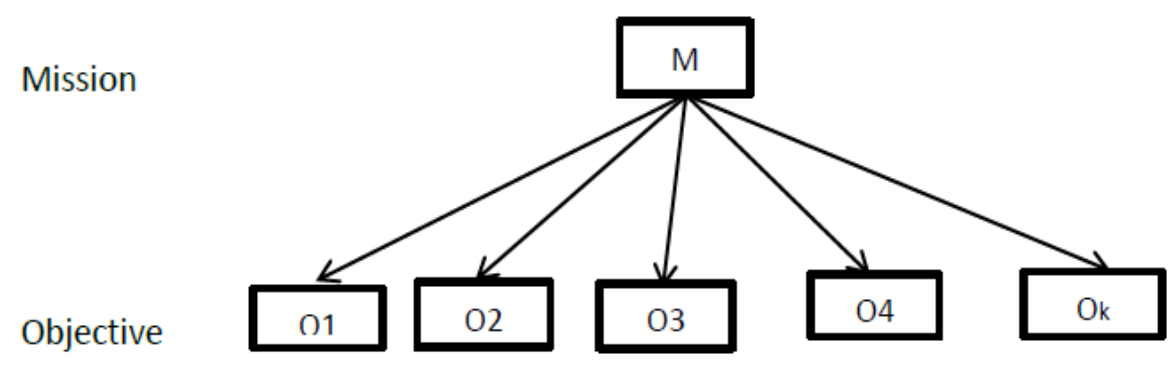

First step

Objective

Goal

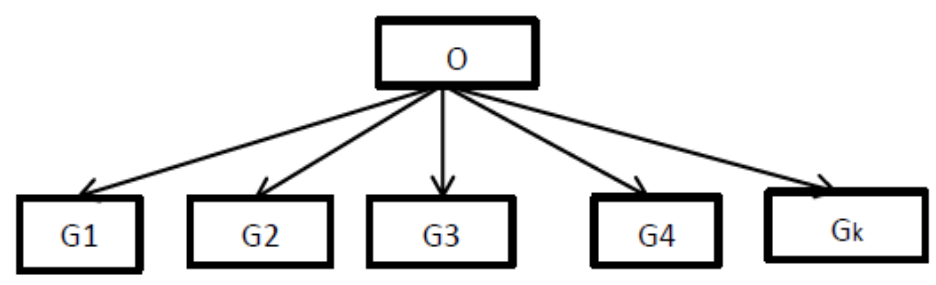

Second step

Goal

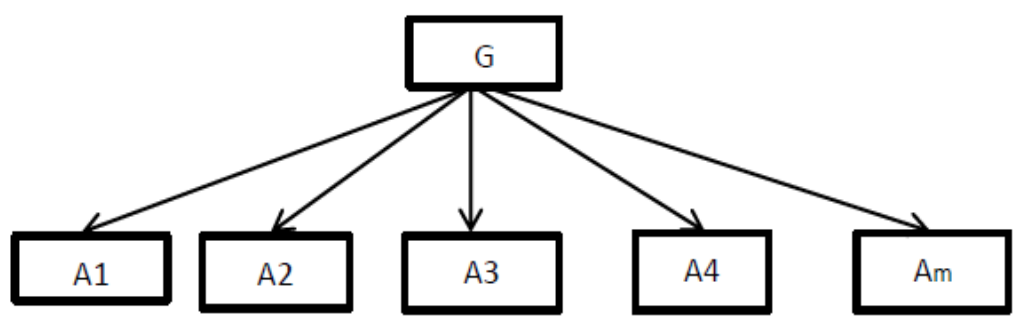

Third step 
The research model employs the pairwise comparison method. The ratio scale for the pairwise comparison requires decision makers to allocate 100 points between each pair. As the number of variables increases in each step, different judgment quantification are required for that process. The pairwise comparison method is a solution that simplifies the complicated process of decision-making into small sets, which contributes easier decision making. The table below clarifies the process of judgment quantification methods in the research model.

Table 7: Judgment Quantification Methods in the Research Model.

\begin{tabular}{|c|c|c|c|}
\hline Hierarchy Level & Area Specialist & $\begin{array}{c}\text { Judgment } \\
\text { Quantification } \\
\text { Method }\end{array}$ & Ratio Scale \\
\hline Second level & $\begin{array}{l}\text { Importance of } \\
\text { utility objective } \\
\text { with relation to } \\
\text { mission }\end{array}$ & Pairwise comparison & \multirow{3}{*}{$\begin{array}{l}\text { Constant sum } \\
\text { method }\end{array}$} \\
\hline Third level & $\begin{array}{l}\text { Importance of } \\
\text { utility goals with } \\
\text { relation to objective }\end{array}$ & Pairwise comparison & \\
\hline Fourth level & $\begin{array}{l}\text { Importance of } \\
\text { alternative with } \\
\text { relation to goal }\end{array}$ & Pairwise comparison & \\
\hline
\end{tabular}

\subsubsection{Stage 3: Data Collection}

All of the procedures of judgment quantification are going to be calculated through expert panels. Thus the research model requires experts from different organization. 
Expert Panel will concentrate on determining utility goals under utility objectives.

1- Objectives Level Expert panel must have a general understanding of the wide range of utility operations and objectives.

2- Goals Level--- Encourage Community to support geothermal energy project for the improvement of public affairs. The expert panel must have experience in public affairs.

3- Goals level--- Minimizing environmental impact. Expert panel must have experience and knowledge of environmental and wildlife protection.

4- Goals Level--- Reducing the expense of investment energy projects. Expert panel must have experience in planning and assessment management, and power policy and rates.

5- Goals Level--- Improving the technical system for geothermal energy projects. Expert panel must have experience in power, transition, and distribution services.

6- Goals Level--- Minimizing the negative impact on the general public. Expert panel must have experience in agency compliance and governance.

7- Alternatives Level. Expert panel must have experience in the fields of engineering, project management, and technologies.

The general criteria for the expert panel selection includes the following:

- Relevant expertise within the research area.

- Availability and willingness to participate.

- Balanced perspectives and biases. 


\subsubsection{Stage 4: Data Analysis}

The results of judgment quantification from the expert panels will be counted to determine each energy alternative resource as related to the mission. The results of the data analysis will come from formula below:

Mission: The selection the geothermal energy resources that is successful to cover the utility objectives and goals.

Objectives: Utility objective $\mathrm{k}$ with relation to the mission: $O_{k}$, i.e $\mathrm{k}=1, \ldots, \mathrm{k}$.

Goals: Utility goal I with relation to the objective: $G_{I k}$, i.e I=1,...,L.

Alternative: Geothermal energy resource alternatives: $A_{m}$, i.e $\mathrm{m}=1, \ldots, \mathrm{M}$.

$\boldsymbol{V}\left(\boldsymbol{O}_{\boldsymbol{k}}\right)$ : The formula of relationship between the utility objective and the mission.

$\boldsymbol{V}\left(\boldsymbol{G}_{\boldsymbol{I} \boldsymbol{k}}\right)$ : The formula of relationship between utility goal I and objective k.

$\boldsymbol{V}\left(\boldsymbol{A}_{\boldsymbol{m} \boldsymbol{k}}\right)$ : The formula of relationship between geothermal energy resource alternatives $\mathrm{m}$ to goal I with respect to objective $\mathrm{k}$.

$\boldsymbol{V}\left(\boldsymbol{E} \boldsymbol{E} \boldsymbol{V}_{\boldsymbol{m}}\right)$ : The formula of geothermal energy resource alternatives $\mathrm{m}$ to the mission.

The research model will work with the inconsistency analysis method that depends on the results from the expert panels. The table below shows how inconsistency analysis works with the research model. 
Table 8: Inconsistency Analysis Method for Research Model

\begin{tabular}{|c|c|c|}
\hline Panel & Research area & Expert inconsistency \\
\hline \multirow{7}{*}{ Experts Panel Members } & Utility Objective & \multirow{7}{*}{ Inconsistency Analysis } \\
\hline & $\begin{array}{c}\text { Encourage Community to } \\
\text { Support Geothermal } \\
\text { Energy Projects }\end{array}$ & \\
\hline & $\begin{array}{c}\text { Minimize Environmental } \\
\text { Impact }\end{array}$ & \\
\hline & $\begin{array}{c}\text { Reduce Expense of } \\
\text { Investment Energy Projects }\end{array}$ & \\
\hline & $\begin{array}{c}\text { Technical Options } \\
\text { Improvement for } \\
\text { Geothermal Energy } \\
\text { Projects }\end{array}$ & \\
\hline & $\begin{array}{l}\text { Minimize the Negative } \\
\text { Impact on General Public }\end{array}$ & \\
\hline & Alternatives Level & \\
\hline
\end{tabular}

\subsection{Establishment of the Expert Panels}

Decision analysis is one of the more important aspects for simplifying the problem, and that is the reason for using this method. Model development is a requirement for optimizing one or more objectives that are impacted by physical, structural, and policy constraints in a static or deterministic setting [325]. One of the challenges in using the model is to find the right experts, and how to reach the best results from probability and evaluation towards the mission. The procedure for selecting the experts requires restrict rules to ensure that those experts have an interest in and relationship to this specific study. This will help to provide better opinions, feedback, and judgments in the different research areas, [325] such as developing national technology policy [326], multiple prospective and decision modeling [327], medicine[328], decision making for elderly persons [329], medical 
and health care [330], psychological characteristics and strategies [331], and technology evaluation and acquisition strategies [332].

It is very important before building expert panels to talk with experts and to understand their knowledge and opinions about the problems set before them in the study. This process, like literature reviews, helps to find which experts will participate in the panel. The number of experts who will participate in the panels depends on the objective and the analysis that will follow.

An expert is a person who depends on his/her knowledge, experience, and opinion to give his/her feedback to make the best choice in the decision- making process [333][334]. It is important to use expert judgment in the analysis of the decision model in case of design issues that may affect the results of the research. To create an expert panel, it is necessary to establish two criteria: expert panels must have balance in the diversity of knowledge or experience, and they must be unbiased because that will have negative impact on the analysis of the research study. In addition the researchers must know who is suitable as an expert, and how many experts are required by looking at the size of the research and the analysis required. The researchers are required to make guidelines as to how to select the experts and how to decide the qualifications of the experts who will be considered for the panels. As a result of these guidelines, experts are chosen according to the following:

- Relevant expertise within the research area: Experts must have knowledge and experience in this field. The panel must have diversity of knowledge, and not be 
limited by one expert because experts must be able to make decisions that require diversity of knowledge, experience, and information.

- Availability and willingness to participate: The people who choose to be experts for the panels must have the ability to give their opinions and feedback without external pressure to make decisions. They can end their participation as panelists whenever they like, so they have the freedom to explain and express their ideas in the way they like.

- Balanced perspectives and biases: In the selection of the expert panels, it is important to choose experts from different organizations who do not know each other. Although there is an advantage to people who work together and understand each other well, this selection will lead to biases toward one decision, which will not be good for the hierarchy decision-making process. This process of decision-making will have a positive impact on the result because no one panelist will affect another in providing feedback on the hierarchy of decisions. In addition, the process must work to prevent occurring conflicts, which will have a negative impact on the result.

Experts will help to do more than one job during their participation as panelists in the research model, which can be summarize in the following points:

- Examining the research model to see if it needs to re-edited or if more criteria needs to be added.

- Giving feedback for judgment quantification to all levels of the model.

- Checking the final research of the model. 
To create the expert panels for the research model, the following steps are required:

- Identify expert requirements: According to the research and literature review, the panels require experts who have knowledge in the development of geothermal energy resources; in the development of technology for obtaining the best service; in renewable energy projects; in power generation; in the environmental, social, and economic sectors; and academics in relation to this field.

- Making a list of names of all expert panelists, and the research study specialization of each one on the panel. A collection of a list of all of the names that will come from literature review that includes government reports, reports from the state about this field of geothermal energy resources, and renewable energy projects.

- Invitation process: On the invitation, ask experts if they agree to participate in the model, and send an email to all experts.

\subsection{Pairwise Comparisons}

The pairwise comparisons are used for identifying the number of comparisons required for the decision element. The formula used for number of comparison is $(\mathrm{N})$ and

$\mathrm{N}$ is calculate by $\left(\mathrm{n}=\frac{N \times(N-1)}{2}\right)$. For instance, if the model has six elements, the number of pairwise comparisons will be $6 \times 5 / 2$, therefore the result will be fifteen comparisons in the decision. If more elements participate, more numbers of pairwise comparisons will be obtained and the complexity of the decision analysis will increase. 


\subsection{Inconsistency}

In the research model, the expert panels will use the constant sum method for obtaining accurate values. This process requires the experts to choose one from two pairs in the decision, and the total of both pairs is 100 points. It is important to examine any mistakes that may occur by the experts during the selection between the pairs of the decision. Therefore it is important to measure the inconsistency of the variance from the relative value of the decision variable [335].

A mistake in judgment occurs because humans cannot always make right decisions. Some inconsistencies in judgment aren't too big so they can be measured and ignored while other inconsistencies can create problems, and cannot be solved and answered. The range of inconsistency cannot exceed $0.1(\leq 0.1)$., If an expert has an inconsistency greater than 0.1 , the calculation must be repeated to find where the mistake is., and the process of deciding between the pairs must be repeated once again. The process of repeating the calculation continues until the result reaches under or equal to 0.1 .

The process for calculating inconsistencies is clarified in the steps that follow. The decision variable for $n$ will become $n !$, and it is simplified with vectors $r 1, r 2, r 3, \ldots, r n$. For example 5! will become 120 orientations like ABCD ABDC ACBD ACDB,......, DBCA. The same value in the result will occur if all experts have the same idea. Each panelist has different opinions, so the result will not be the same. This inconsistency is used in the HDM methodology for obtaining the variance by calculation [336]. The formula of inconsistency is clarified below: 
Let ;

$r_{i j}$ is the relative value of the $i^{\text {th }}$ element in the $j^{\text {th }}$ orientation for an expert

$\bar{r} \quad i$ is the mean relative of the $i^{\text {th }}$ element

Inconsistency for the $i^{\text {th }}$ element is

$\frac{1}{n !} \sum_{j=1}^{n !}\left(\bar{r}_{i}-r_{i j}\right) \quad{ }^{2}$ for $\mathrm{i}=1,2, \ldots, \mathrm{n}$

Inconsistency of the expert for $\mathrm{n}$ element decision variable is:

$\frac{1}{n} \sum_{i=1}^{n} \frac{1}{n !} \sqrt{\sum_{j=1}^{n !}\left(\overline{r i}-r_{i j}\right)^{2}}$ 


\section{CHAPTER 5: RESULT AND DATA ANALYSIS}

This part will explain the judgment quantification results, experts'

inconsistencies, and the areas of disagreement between the experts on the panel. A pairwise comparison method software was used for analyzing the results of the quantified expert judgment. As explained in the previous chapters, the value of disagreement among the group will be less than or equal to 0.1 .

\subsection{Expert Panel}

The seven expert panel members have expertise in the geothermal technologies associated with geothermal energy projects. Based on the list of alternatives on the survey questionnaire, they noted which alternative is more convenient in the decision- making process with respect to the mission of our project, objective, and goals. The panel was comprised of experts from the following organizations: Two were from government agencies, one from university, and four from non-government organizations. The table below explains the experts and which institutions they are working at.

Table 9: Expert Panel and Institutions

\begin{tabular}{|c|c|c|}
\hline Expert & Affiliation & Institution \\
\hline Expert 1 & $\begin{array}{c}\text { Oregon Department of } \\
\text { Energy-Geothermal Energy } \\
\text { Council }\end{array}$ & Government \\
\hline Expert 2 & Energy Trust Of Oregon & $\begin{array}{c}\text { Non-Government } \\
\text { Organization }\end{array}$ \\
\hline Expert 3 & $\begin{array}{c}\text { Oregon Environmental } \\
\text { Council }\end{array}$ & $\begin{array}{c}\text { Non-Government } \\
\text { Organization }\end{array}$ \\
\hline
\end{tabular}




\begin{tabular}{|c|c|c|}
\hline Expert 4 & $\begin{array}{c}\text { Oregon public Utility } \\
\text { Commission }\end{array}$ & Government \\
\hline Expert 5 & Renewable Northwest & $\begin{array}{c}\text { Non-Government } \\
\text { Organization }\end{array}$ \\
\hline Expert 6 & Oregon State University & Academia \\
\hline Expert 7 & Altarock energy,Inc & $\begin{array}{c}\text { Non-Government } \\
\text { Organization }\end{array}$ \\
\hline
\end{tabular}

\subsubsection{Expert Panel Results}

The seven experts panel members were asked to use the online survey questionnaire link that included instructions about how to use the Hierarchical Decision Model (HDM) to evaluate different criteria that effect geothermal energy with respect to our goal that was mentioned in the mission (Technology Assessment Model of Developing Geothermal Energy Resources for Supporting the Electrical System in Oregon). The figure below shows the contribution results from the expert panel.

Figure 21: The Global Weight of Alternative Geothermal Energy Technology

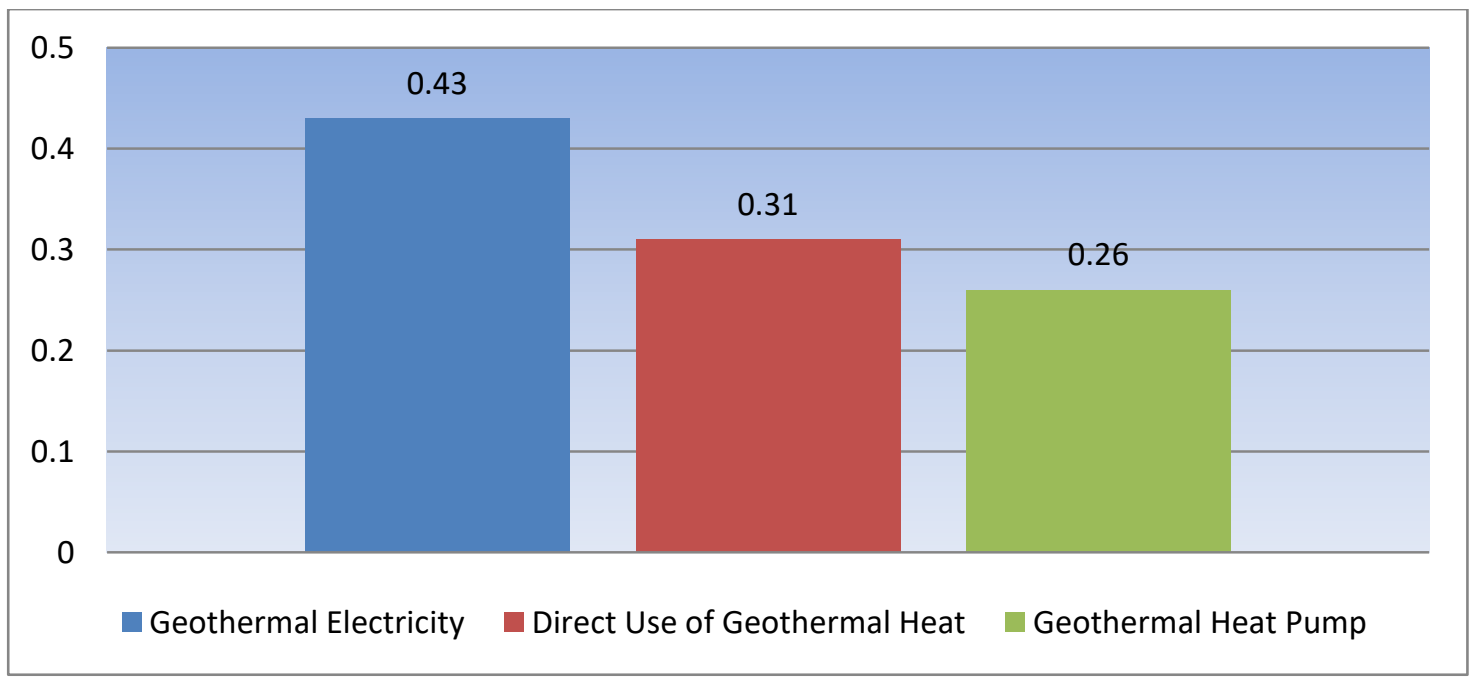


The results in Figure (21) show that "Geothermal Electricity", with a rating of $43 \%$, was ranked as the most important alternative with respect to mission, objectives, and goals. "Direct Use of Geothermal Heat" was ranked as the second most important alternative with 31\%, and the "Geothermal Heat Pump" was ranked as the least importance alternative with $26 \%$ for developing geothermal energy sources in Oregon.

\subsubsection{Analysis of Expert Panel Results}

The individual expert opinions about the relative importance in weight of each alternative contributed to finding the most importance alternative with respect to mission statement. The mean of seven experts showed in table [10]. All experts have knowledge and experience in geothermal energy, and they gave their judgment in the questionnaire survey. The results of the comparison is among the acceptance level of consistency in their judgment, and consistency level must be less than or equal 0.1 . The results showed that the mean level of disagreement was 0.095 between the experts that participated in questionnaire of survey. At the same time, the individual expert's judgments was among the acceptable range, which is 0 to 0.03 . The table below shows the individual expert judgment for each alternative. All individual inconsistencies are among acceptable level of range.

Table 10: Individual Expert Judgment for Each Alternative

\begin{tabular}{|c|c|c|c|c|}
\hline Expert & GHP & Direct Heat & $\begin{array}{c}\text { Geothermal } \\
\text { Electricity }\end{array}$ & Inconsistency \\
\hline Expert 1 & 0.26 & 0.28 & 0.46 & 0 \\
\hline Expert 2 & 0.26 & 0.46 & 0.28 & 0.01 \\
\hline
\end{tabular}




\begin{tabular}{|c|c|c|c|c|}
\hline Expert 3 & 0.32 & 0.37 & 0.31 & 0.02 \\
\hline Expert 4 & 0.33 & 0.3 & 0.37 & 0.02 \\
\hline Expert 5 & 0.14 & 0.07 & 0.79 & 0.02 \\
\hline Expert 6 & 0.33 & 0.33 & 0.33 & 0.01 \\
\hline Expert 7 & 0.19 & 0.36 & 0.46 & 0.03 \\
\hline Mean & 0.26 & 0.31 & 0.43 & \\
\hline Disagreement & & 0.095 & \\
\hline
\end{tabular}

Figure 22: Individual Expert Judgment for Each Alternative

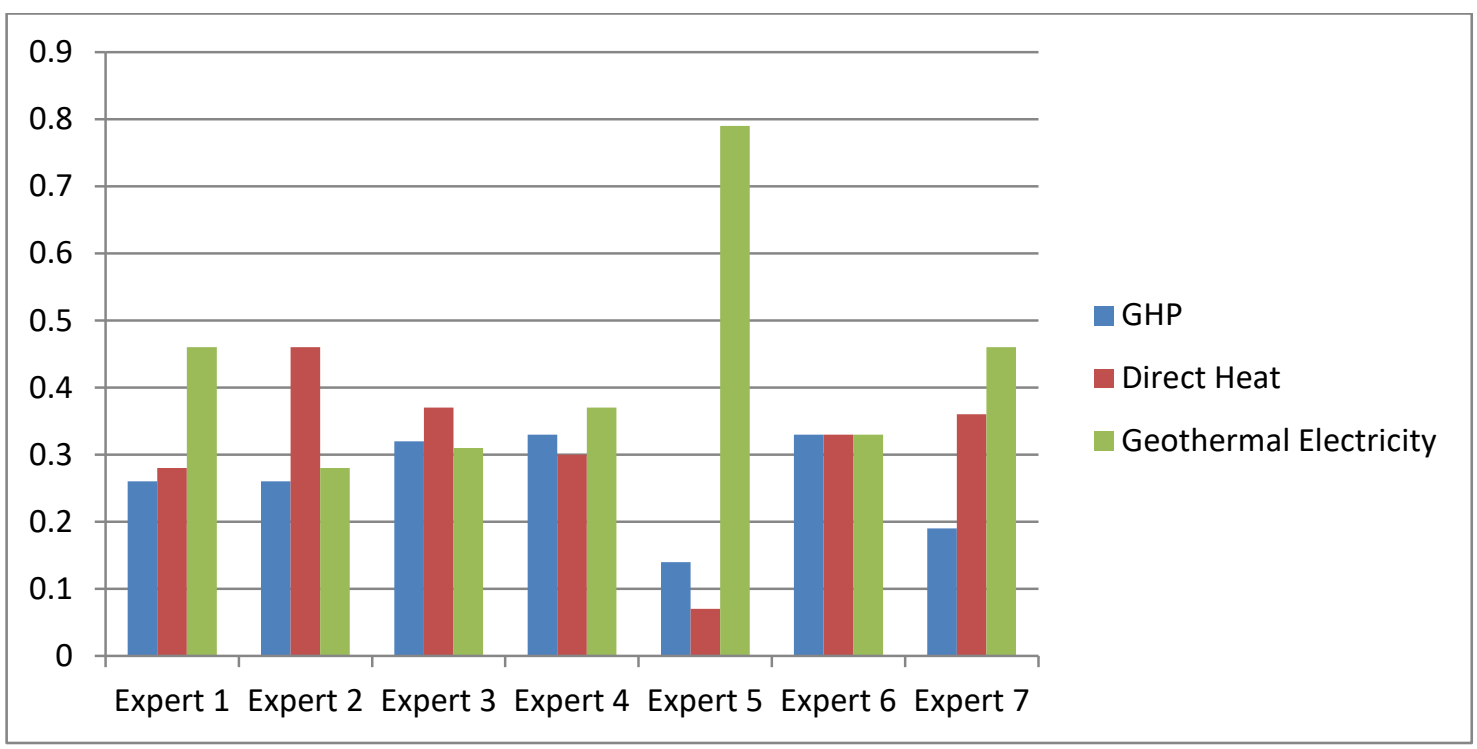

From the results in the table above, the majority of the experts chose geothermal electricity as the most important electricity alternative. The reason for this is that electricity is used in a variety of different applications like heating, cooling, industry, medical, and so forth, and the population of people and their demand for electricity is always increasing. 
The outcome analysis of the results in Appendix $\mathrm{C}$ showed that in terms of objectives that minimizing environmental impact was rated at the highest value at 0.26 with respect to the mission. Within the category of minimizing environmental impact, seismic activity and GHG emissions had higher values as well because they require more attention and work to reduce the negative impact from the process of geothermal energy activities.

A numerical analysis was also made to know what are the most important objectives through looking at different experts segment (background of the organization, position, and education) and identify if this result of analysis will affect decision making or not.

The table [11] shows minimizing environmental impact and reducing expense of investment energy cost are the most important objectives for all experts either as their first choice or their second most important choice.

Table 11: Importance of Objectives from Different Characteristics of the Experts

\begin{tabular}{|c|c|c|c|}
\hline \multirow{2}{*}{\multicolumn{2}{|c|}{ Characteristics of Experts }} & \multicolumn{2}{|c|}{ Importance of Objectives } \\
\hline & & Preference choice \#1 & Preference choice \#2 \\
\hline \multirow{3}{*}{ 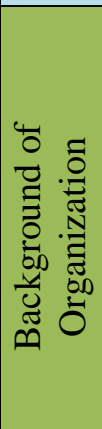 } & Utility & $\begin{array}{c}\text { Minimize Environmental } \\
\text { Impact }\end{array}$ & $\begin{array}{c}\text { Reduce Expense of } \\
\text { Investment Energy Cost }\end{array}$ \\
\hline & Consulting & $\begin{array}{c}\text { Minimize Environmental } \\
\text { Impact }\end{array}$ & $\begin{array}{c}\text { Technical Options } \\
\text { Improvement for } \\
\text { Geothermal Energy Projects }\end{array}$ \\
\hline & Research Lab & $\begin{array}{c}\text { Reduce Expense of } \\
\text { Investment Energy Cost }\end{array}$ & $\begin{array}{c}\text { Technical Options } \\
\text { Improvement for } \\
\text { Geothermal Energy Projects }\end{array}$ \\
\hline
\end{tabular}




\begin{tabular}{|c|c|c|c|}
\hline & University & $\begin{array}{c}\text { Reduce Expense of } \\
\text { Investment Energy Cost }\end{array}$ & $\begin{array}{l}\text { Minimize the Negative } \\
\text { Impact on the General } \\
\text { Public }\end{array}$ \\
\hline \multirow{4}{*}{ 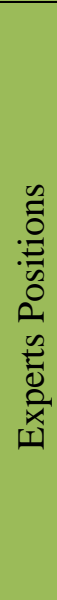 } & Management & $\begin{array}{c}\text { Minimize Environmental } \\
\text { Impact }\end{array}$ & $\begin{array}{c}\text { Reduce Expense of } \\
\text { Investment Energy Cost }\end{array}$ \\
\hline & Planning & $\begin{array}{c}\text { Reduce Expense of } \\
\text { Investment Energy Cost }\end{array}$ & $\begin{array}{l}\text { Minimize the Negative } \\
\text { Impact on the General } \\
\text { Public }\end{array}$ \\
\hline & Policy & $\begin{array}{l}\text { Reduce Expense of } \\
\text { Investment Energy Cost }\end{array}$ & $\begin{array}{c}\text { Technical Options } \\
\text { Improvement for } \\
\text { Geothermal Energy Projects }\end{array}$ \\
\hline & Environment & $\begin{array}{c}\text { Minimize Environmental } \\
\text { Impact }\end{array}$ & $\begin{array}{l}\text { Minimize the Negative } \\
\text { Impact on the General } \\
\text { Public }\end{array}$ \\
\hline \multirow{3}{*}{.0 } & Bachelor Degree & $\begin{array}{c}\text { Minimize Environmental } \\
\text { Impact }\end{array}$ & $\begin{array}{c}\text { Reduce Expense of } \\
\text { Investment Energy Cost }\end{array}$ \\
\hline & Master Degree & $\begin{array}{c}\text { Minimize Environmental } \\
\text { Impact }\end{array}$ & $\begin{array}{c}\text { Technical Options } \\
\text { Improvement for } \\
\text { Geothermal Energy Projects }\end{array}$ \\
\hline & Ph.D. Degree & $\begin{array}{c}\text { Reduce Expense of } \\
\text { Investment Energy Cost }\end{array}$ & $\begin{array}{l}\text { Encourage Community to } \\
\text { Support Geothermal Energy } \\
\text { Project }\end{array}$ \\
\hline
\end{tabular}

Table [12] analyzes the input from the experts., As mentioned before, all of the experts were from different organizations, and the results of the input showed that while not all of them selected the same objectives as the most important, the majority of the experts rated a reduction in the expense of investment energy projects as the most important factor, and ranked this first or second. The table below clarified this process of selection. 
Table 12: Identifying the Important Objectives Made by the Experts

\begin{tabular}{|c|c|c|}
\hline \multicolumn{2}{|c|}{ Importance of Objectives } \\
\hline & $\begin{array}{c}\text { Preference Choice } \\
\# 1\end{array}$ & $\begin{array}{c}\text { Preference Choice } \\
\# 2\end{array}$ \\
\hline $\begin{array}{c}\text { Reduce Expense of } \\
\text { Investment Energy } \\
\text { Projects }\end{array}$ & 3 & 2 \\
\hline $\begin{array}{c}\text { Technical Options } \\
\text { Improvement for } \\
\text { Geothermal Energy } \\
\text { Projects }\end{array}$ & 2 & 1 \\
\hline $\begin{array}{c}\text { Minimize Environmental } \\
\text { Impact }\end{array}$ & 2 & 0 \\
\hline $\begin{array}{c}\text { Minimize the Negative } \\
\text { Impact on the General } \\
\text { Public }\end{array}$ & 1 & 2 \\
\hline $\begin{array}{c}\text { Encourage Community to } \\
\text { Support Geothermal } \\
\text { Energy Project }\end{array}$ & 0 & 2 \\
\hline
\end{tabular}

Figure 23: Preference of Objectives

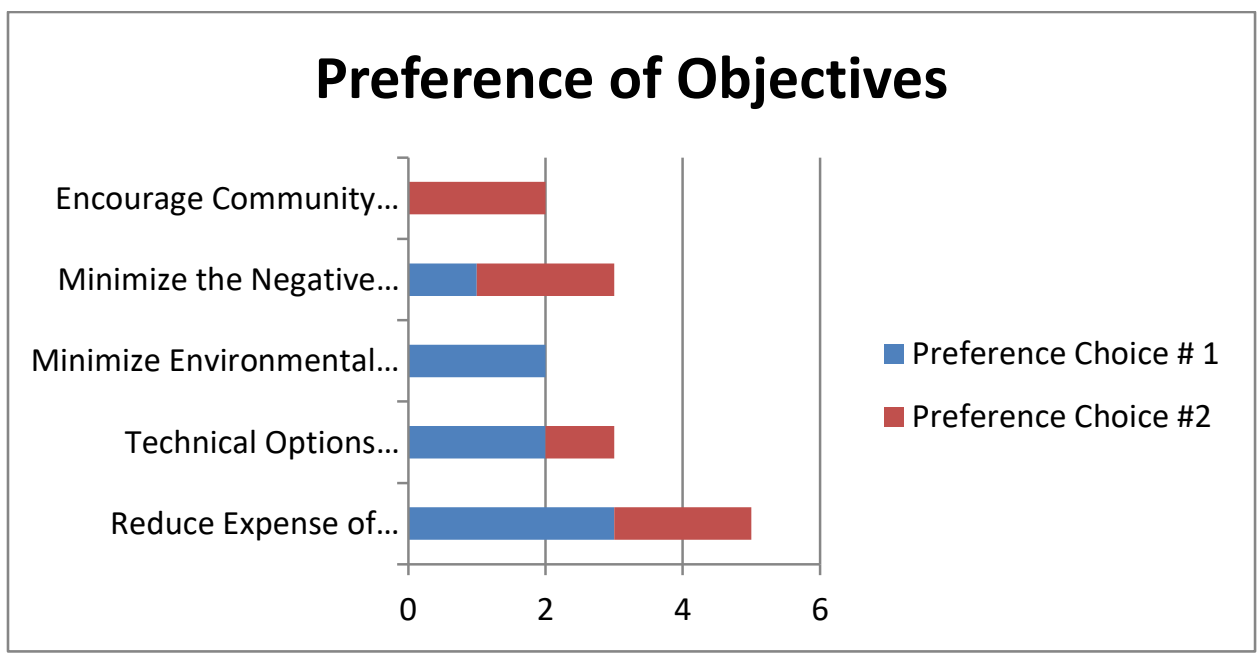


As expected, minimizing environmental impact is the most important objective for Oregon since Oregon encourages all investment in renewable energy projects to serve and protect the environment. All of the experts chose the most important out of fourteen designated goals, and then ranked these selections from one to four, one being the highest and four, the lowest. Creating new job opportunities and minimizing noise and odor were ranked the highest among the goals. The table [13] identifies the important goals made by the experts.

Table 13: Identifying the Important Goals Chosen by the Experts

\begin{tabular}{|c|c|c|c|c|}
\hline \multicolumn{5}{|c|}{ Importance of Goals } \\
\hline & $\begin{array}{c}\text { Preference } \\
\text { Choice \# 1 }\end{array}$ & $\begin{array}{c}\text { Preference } \\
\text { Choice \# 2 }\end{array}$ & $\begin{array}{c}\text { Preference } \\
\text { Choice \# 3 }\end{array}$ & $\begin{array}{c}\text { Preference } \\
\text { Choice \# 4 }\end{array}$ \\
\hline $\begin{array}{c}\text { Minimize Noise } \\
\text { and Odor }\end{array}$ & 4 & 2 & 1 & 0 \\
\hline $\begin{array}{c}\text { Create New Job } \\
\text { Opportunity }\end{array}$ & 2 & 3 & 0 & 0 \\
\hline $\begin{array}{c}\text { Social } \\
\text { Acceptance }\end{array}$ & 1 & 1 & 1 & 0 \\
\hline $\begin{array}{c}\text { Minimizing } \\
\text { Property } \\
\text { Damage for } \\
\text { Reducing Impact } \\
\text { on Life Style }\end{array}$ & 0 & 1 & 1 & 1 \\
\hline $\begin{array}{c}\text { Equipment } \\
\text { Manufacturing } \\
\text { Development }\end{array}$ & 0 & 0 & 3 & 2 \\
\hline $\begin{array}{c}\text { Minimize } \\
\text { Capital Cost }\end{array}$ & 0 & 0 & 1 & 0 \\
\hline $\begin{array}{c}\text { Minimize } \\
\text { Operation Cost }\end{array}$ & 0 & & & 2 \\
\hline
\end{tabular}




\begin{tabular}{|c|c|c|c|c|}
\hline $\begin{array}{c}\text { Minimizing the } \\
\text { Demand of } \\
\text { Critical } \\
\text { Resources }\end{array}$ & 0 & 0 & 1 & 0 \\
\hline Seismic Activity & 0 & 0 & 0 & 2 \\
\hline Economic Boost & 0 & 0 & 0 & 1 \\
\hline
\end{tabular}

From the table [13], the majority of the experts chose minimizing noise and odor, creating new job opportunity, and social acceptance as the most important goals for this research study in Oregon.

Figure 24: Preference of Goal

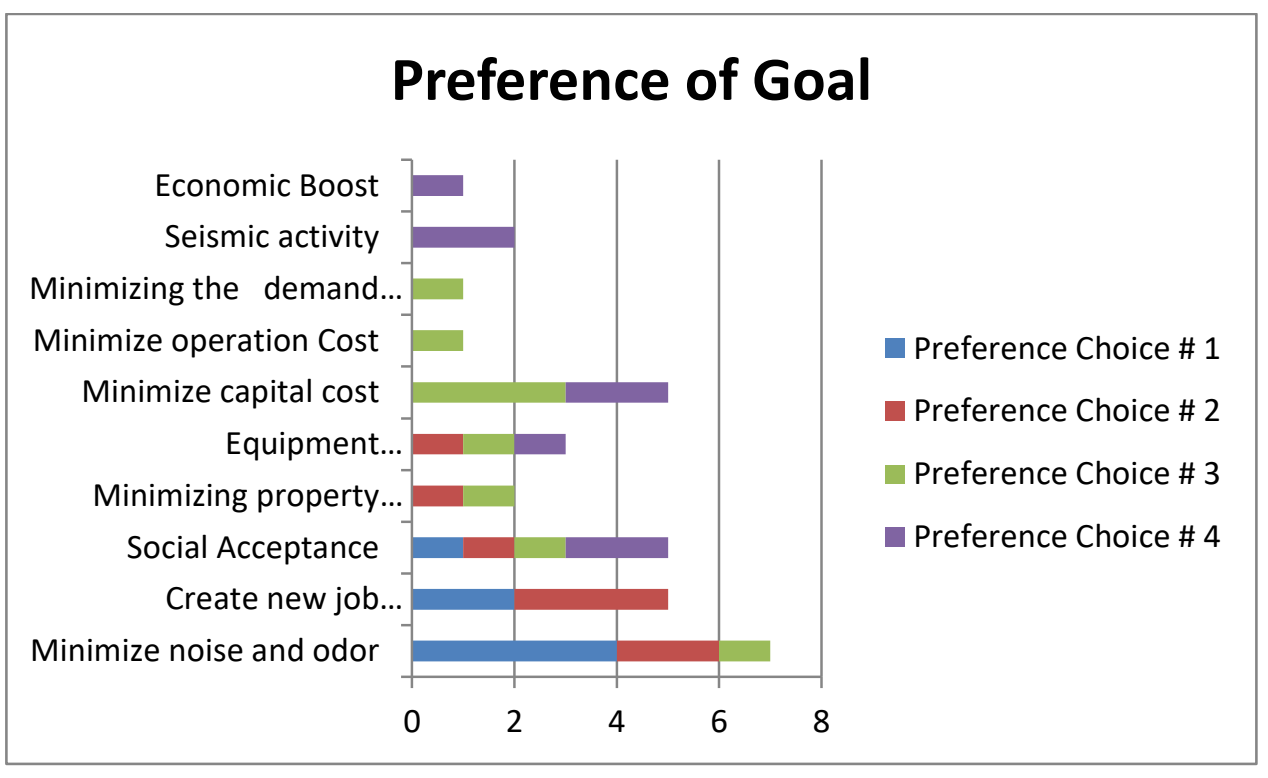

To have more understanding of the most important goals for improvement of geothermal energy sources, different perspectives of experts' characteristics were analyzed. Table [14] explained the most important goals from different perspectives of experts. 
Table 14: Importance of Goals from Different Characteristics of the Experts

\begin{tabular}{|c|c|c|c|c|c|}
\hline \multirow{2}{*}{\multicolumn{2}{|c|}{$\begin{array}{l}\text { Characteristics of } \\
\text { Experts }\end{array}$}} & \multicolumn{4}{|c|}{ Importance of Goals } \\
\hline & & \multirow{2}{*}{$\begin{array}{c}\begin{array}{c}\text { Preference choice } \\
\# 1\end{array} \\
\begin{array}{c}\text { Minimize Noise } \\
\text { and Odor }\end{array}\end{array}$} & \multirow{2}{*}{$\begin{array}{c}\text { Preferenc } \\
\text { e choice } \\
\# 2 \\
\begin{array}{c}\text { Social } \\
\text { Acceptanc } \\
\text { e }\end{array}\end{array}$} & \multirow{2}{*}{$\begin{array}{c}\text { Preference } \\
\text { choice \#3 } \\
\text { Minimize } \\
\text { Capital Cost }\end{array}$} & \multirow{2}{*}{$\begin{array}{c}\text { Preference choice } \\
\qquad \begin{array}{c}\text { A4 } \\
\text { Seismic Activity }\end{array}\end{array}$} \\
\hline \multirow{4}{*}{ 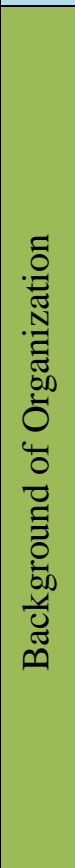 } & Utility & & & & \\
\hline & Consulting & $\begin{array}{l}\text { Create New Job } \\
\text { Opportunity/Mini } \\
\text { mize Noise and } \\
\text { Odor }\end{array}$ & $\begin{array}{c}\text { GHG } \\
\text { Emission }\end{array}$ & $\begin{array}{c}\text { Minimizing } \\
\text { the Demand } \\
\text { of Critical } \\
\text { Resources }\end{array}$ & Economic Boost \\
\hline & $\begin{array}{l}\text { Research } \\
\text { Lab }\end{array}$ & $\begin{array}{l}\text { Minimize Noise } \\
\text { and Odor }\end{array}$ & $\begin{array}{c}\text { Create } \\
\text { New Job } \\
\text { Opportuni } \\
\text { ty }\end{array}$ & $\begin{array}{c}\text { Minimize } \\
\text { Capital Cost }\end{array}$ & $\begin{array}{l}\text { Increasing the } \\
\text { Capacity of the } \\
\text { Energy System }\end{array}$ \\
\hline & University & $\begin{array}{l}\text { Create New Job } \\
\text { Opportunity }\end{array}$ & $\begin{array}{l}\text { Increasing } \\
\text { the } \\
\text { Capacity } \\
\text { of the } \\
\text { Energy } \\
\text { System }\end{array}$ & $\begin{array}{l}\text { Seismic } \\
\text { Activity }\end{array}$ & $\begin{array}{c}\text { Social } \\
\text { Acceptance/Econo } \\
\text { mic Boost/ } \\
\text { Minimize Capital } \\
\text { Cost/Minimize } \\
\text { Operation Cost }\end{array}$ \\
\hline \multirow{4}{*}{ 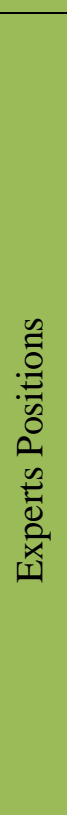 } & $\underset{\mathrm{t}}{\text { Managemen }}$ & $\begin{array}{l}\text { Minimize Noise } \\
\text { and Odor }\end{array}$ & $\begin{array}{l}\text { Minimize } \\
\text { Capital } \\
\text { Cost }\end{array}$ & $\begin{array}{c}\text { Social } \\
\text { Acceptance }\end{array}$ & $\begin{array}{l}\text { Create New Job } \\
\text { Opportunity }\end{array}$ \\
\hline & Planning & $\begin{array}{l}\text { Minimize Noise } \\
\text { and Odor }\end{array}$ & $\begin{array}{c}\text { Create } \\
\text { New Job } \\
\text { Opportuni } \\
\text { ty }\end{array}$ & $\begin{array}{c}\text { Social } \\
\text { Acceptance }\end{array}$ & $\begin{array}{c}\text { Equipment } \\
\text { Manufacturing } \\
\text { Development }\end{array}$ \\
\hline & Policy & $\begin{array}{l}\text { Minimize Noise } \\
\text { and Odor }\end{array}$ & $\begin{array}{c}\text { Create } \\
\text { New Job } \\
\text { Opportuni } \\
\text { ty }\end{array}$ & $\begin{array}{c}\text { Minimize } \\
\text { Capital Cost }\end{array}$ & $\begin{array}{l}\text { Increasing the } \\
\text { Capacity of the } \\
\text { Energy System }\end{array}$ \\
\hline & $\begin{array}{c}\text { Environmen } \\
\mathrm{t}\end{array}$ & $\begin{array}{l}\text { Minimize Noise } \\
\text { and Odor }\end{array}$ & $\begin{array}{c}\text { Create } \\
\text { New Job } \\
\text { Opportuni } \\
\text { ty }\end{array}$ & $\begin{array}{l}\text { Minimizing } \\
\text { the Demand } \\
\text { of Critical } \\
\text { Resources }\end{array}$ & Economic Boost \\
\hline
\end{tabular}




\begin{tabular}{|c|c|c|c|c|c|}
\hline \multirow{3}{*}{ 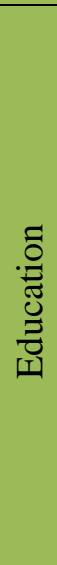 } & $\begin{array}{l}\text { Bachelor } \\
\text { Degree }\end{array}$ & $\begin{array}{c}\text { Social } \\
\text { Acceptance }\end{array}$ & $\begin{array}{l}\text { Minimize } \\
\text { Noise and } \\
\text { Odor }\end{array}$ & $\begin{array}{c}\text { Minimize } \\
\text { Capital Cost }\end{array}$ & Seismic Activity \\
\hline & $\begin{array}{l}\text { Master } \\
\text { Degree }\end{array}$ & $\begin{array}{l}\text { Minimize Noise } \\
\text { and Odor }\end{array}$ & $\begin{array}{c}\text { Create } \\
\text { New Job } \\
\text { Opportuni } \\
\text { ty }\end{array}$ & $\begin{array}{c}\text { Equipment } \\
\text { Manufacturi } \\
\text { ng } \\
\text { Developmen } \\
\mathrm{t}\end{array}$ & $\begin{array}{c}\text { Minimize Capital } \\
\text { Cost }\end{array}$ \\
\hline & $\begin{array}{l}\text { Ph.D. } \\
\text { Degree }\end{array}$ & $\begin{array}{c}\text { Create New Job } \\
\text { Opportunity }\end{array}$ & $\begin{array}{l}\text { Minimize } \\
\text { Noise and } \\
\text { Odor }\end{array}$ & $\begin{array}{l}\text { Minimize } \\
\text { Capital cost }\end{array}$ & $\begin{array}{l}\text { Increasing the } \\
\text { Capacity of the } \\
\text { Energy System }\end{array}$ \\
\hline
\end{tabular}

Most of the experts chose geothermal electricity and the direct use of geothermal heat as the most important alternative for developing geothermal energy sources in Oregon. Table [15] explains the most important feature of each goal for every alternative of geothermal energy that was chosen by the experts.

Table 15: The Most Important Features for Geothermal Energy Alternatives that Were Chosen by the Experts

\begin{tabular}{|c|c|c|c|}
\hline \multicolumn{4}{|c|}{ Alternative } \\
\hline & GHP & Direct Heat & $\begin{array}{c}\text { Geothermal } \\
\text { Electricity }\end{array}$ \\
\hline $\begin{array}{c}\text { Create New job } \\
\text { opportunity }\end{array}$ & 1 & 2 & 6 \\
\hline Social Acceptance & 3 & 4 & 6 \\
\hline GHG Emission & 3 & 3 & 5 \\
\hline Land Requirement & 4 & 6 & 4 \\
\hline Seismic Activity & 4 & 3 & 6 \\
\hline
\end{tabular}




\begin{tabular}{|c|c|c|c|}
\hline $\begin{array}{c}\text { Using the Land for } \\
\text { Other Purposes }\end{array}$ & 3 & 2 & 6 \\
\hline $\begin{array}{c}\text { Minimize Capital } \\
\text { Cost }\end{array}$ & 1 & 3 & 6 \\
\hline $\begin{array}{c}\text { Minimize Operation } \\
\text { Cost }\end{array}$ & 2 & 2 & 5 \\
\hline $\begin{array}{c}\text { Economic Boost } \\
\text { Minimizing the } \\
\text { Demand of Critical } \\
\text { Resources }\end{array}$ & 2 & 5 & 6 \\
\hline $\begin{array}{c}\text { Increasing the } \\
\text { Capacity of the } \\
\text { Energy System }\end{array}$ & 3 & 3 & 5 \\
\hline $\begin{array}{c}\text { Equipment } \\
\text { Manufacturing } \\
\text { Development }\end{array}$ & 3 & 4 & 6 \\
\hline $\begin{array}{c}\text { Minimize Noise and } \\
\text { Odor }\end{array}$ & 3 & 4 & 7 \\
\hline $\begin{array}{c}\text { Minimizing Property } \\
\text { Damage for } \\
\text { Life Style }\end{array}$ & 2 & & 5 \\
\hline
\end{tabular}

Table [15] shows that the most important features for geothermal energy projects were creating new job opportunities and social acceptance. More focus is needed around the research of geothermal energy sources in the geothermal field, and for making the geothermal energy alternatives successful in Oregon. 
Figure 25: Preference of Alternatives
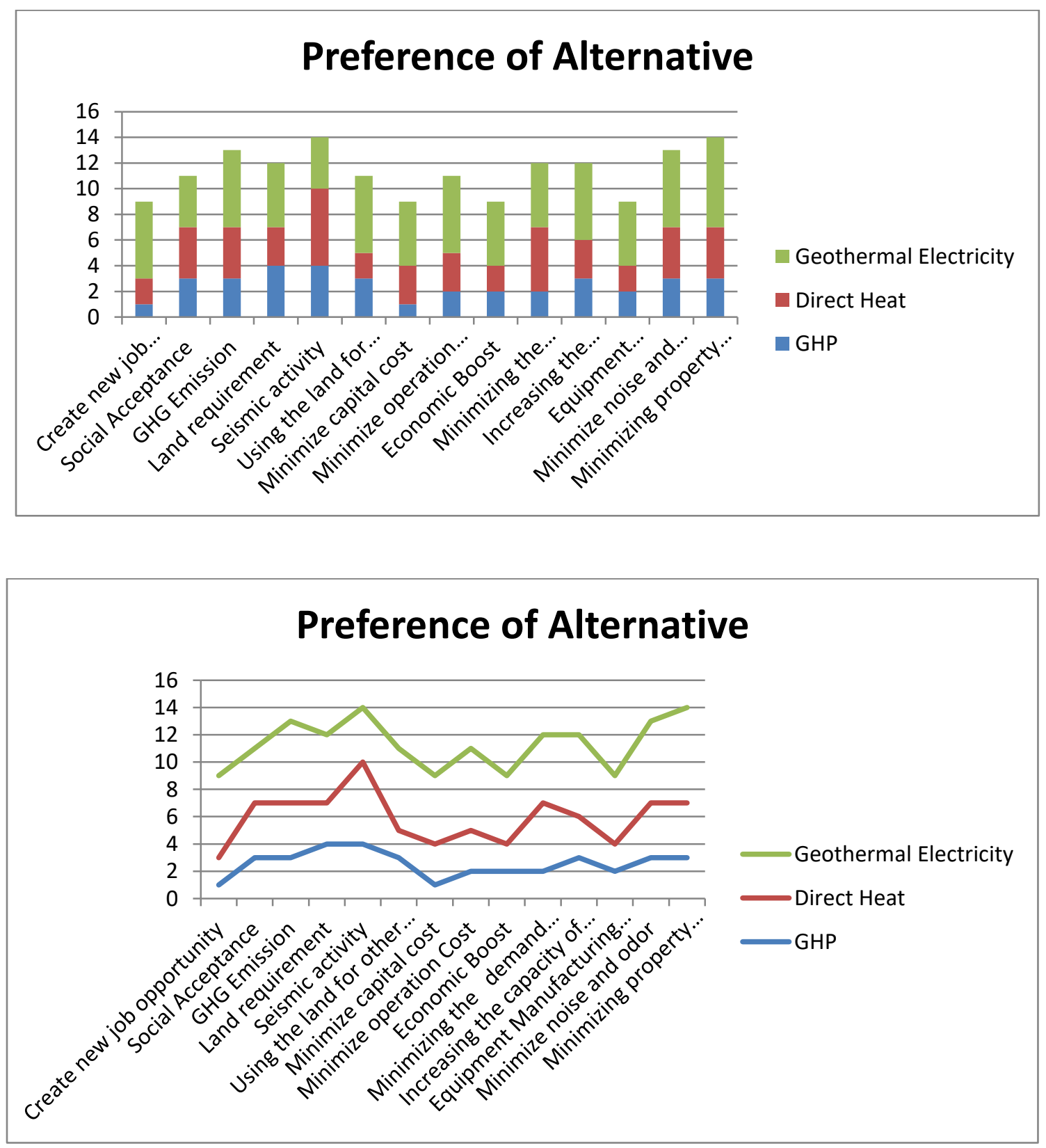

To know which alternative is the most successful with features (goals) for development of geothermal energy, different perspectives of experts' characteristics were analyzed. Table [16] explained this process. 
Table 16: Different Characteristics of Experts for Geothermal Energy Alternatives

\begin{tabular}{|c|c|c|c|c|}
\hline \multirow{2}{*}{\multicolumn{2}{|c|}{$\begin{array}{c}\text { Characteristics of } \\
\text { Experts }\end{array}$}} & \multicolumn{3}{|c|}{ Alternative } \\
\hline & & GHP & Direct Heat & Geothermal \\
\hline \multirow{4}{*}{ 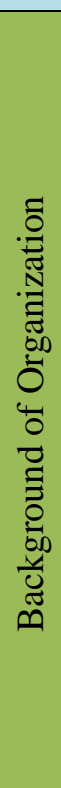 } & Utility & GHG Emission & $\begin{array}{l}\text { Minimize Capital } \\
\text { Cost }\end{array}$ & $\begin{array}{c}\text { Equipment } \\
\text { Manufacturing } \\
\text { Development }\end{array}$ \\
\hline & Consulting & Seismic Activity & $\begin{array}{l}\text { Minimizing the } \\
\text { Demand of Critical } \\
\text { resources }\end{array}$ & $\begin{array}{l}\text { Minimize Noise } \\
\text { and Odor }\end{array}$ \\
\hline & Research Lab & Seismic Activity & Seismic Activity & $\begin{array}{l}\text { Increasing the } \\
\text { Capacity of the } \\
\text { Energy System }\end{array}$ \\
\hline & University & $\begin{array}{c}\text { Seismic Activity/ } \\
\text { GHG } \\
\text { Emission/Create } \\
\text { New Job } \\
\text { Opportunity }\end{array}$ & $\begin{array}{c}\text { Minimize Capital } \\
\text { Cost/Minimize } \\
\text { Operation } \\
\text { Cost/Economic } \\
\text { Boost }\end{array}$ & $\begin{array}{l}\text { Minimizing the } \\
\text { Demand of Critical } \\
\text { Resources/ } \\
\text { Equipment } \\
\text { Manufacturing } \\
\text { Development }\end{array}$ \\
\hline \multirow{4}{*}{ 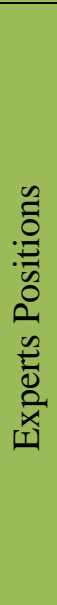 } & Management & Social Acceptance & $\begin{array}{c}\text { Minimize Capital } \\
\text { Cost }\end{array}$ & $\begin{array}{c}\text { Equipment } \\
\text { Manufacturing } \\
\text { Development }\end{array}$ \\
\hline & Planning & Land Requirement & $\begin{array}{l}\text { Create New Job } \\
\text { Opportunity }\end{array}$ & $\begin{array}{l}\text { Using the Land for } \\
\text { Other Purposes }\end{array}$ \\
\hline & Policy & Seismic Activity & Seismic Activity & $\begin{array}{l}\text { Increasing the } \\
\text { Capacity of the } \\
\text { Energy System }\end{array}$ \\
\hline & Environment & $\begin{array}{l}\text { Using the Land for } \\
\text { other purposes }\end{array}$ & $\begin{array}{l}\text { Minimizing the } \\
\text { Demand of Critical } \\
\text { Resources }\end{array}$ & $\begin{array}{l}\text { Increasing the } \\
\text { Capacity of the } \\
\text { Energy System }\end{array}$ \\
\hline \multirow{2}{*}{ 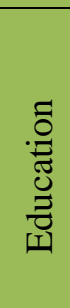 } & $\begin{array}{l}\text { Bachelor } \\
\text { Degree }\end{array}$ & $\begin{array}{l}\text { Using the Land for } \\
\text { Other Purposes }\end{array}$ & $\begin{array}{c}\text { Minimize Operation } \\
\text { Cost }\end{array}$ & $\begin{array}{l}\text { Minimizing the } \\
\text { Demand of Critical } \\
\text { Resources }\end{array}$ \\
\hline & Master Degree & Seismic Activity & $\begin{array}{l}\text { Minimizing the } \\
\text { Demand of Critical } \\
\text { Resources }\end{array}$ & $\begin{array}{c}\text { Equipment } \\
\text { Manufacturing } \\
\text { Development }\end{array}$ \\
\hline
\end{tabular}




\begin{tabular}{|l|l|l|l|}
\hline Ph.D. Degree & Seismic Activity & Seismic Activity & $\begin{array}{l}\text { Increasing the } \\
\text { Capacity of the } \\
\text { Energy System }\end{array}$ \\
\hline
\end{tabular}

From table [16], most experts which is different perspectives of characteristics preferred to choose features of environment as the highest rank. Features of technical were ranked also as one most important for achieving the best benefits of geothermal energy.

In order to understand why there was a difference between what objectives, goals, and alternatives each expert on the panel deemed important and ranked the most highly, the discussion in the discussion section will help to understand their thoughts about the future of geothermal energy and their recommendations for improvement in this sector of renewable energy. All explanations for objectives, goals, and alternative will explain in the discussion part.

\subsection{Criterion-Related Validity}

Managers from different organizations in the Pacific Northwest, who are specialists in renewable energy, environment, and geothermal energy, participated in evaluating the criterion-related validity. Experts were asked to give their judgment in survey questionnaire about the research study. All of the experts agreed that the methodology was a good approach for reaching a decision. They also agreed that all of the nodes that were applied in the HDM methodology that are based off of real life require more attention. This process will lead to more development of geothermal energy sources in Oregon. Also, the experts confirmed that the development of geothermal energy 
technology will grow quickly if there is more attention and focus on the criteria that were used in the methodology. We held a face to face meeting with the expert panel to hear their thoughts on what is required for more development in the future. Experts agreed that applying this model in the future for another state, and by adding more criteria, that this model will be useful for determining what will be required for greater improvement in the geothermal field.

\subsection{Summary of the Study}

A Hierarchical Decision Model (HDM) methodology was used in this research study to reach the value for the technology assessment model of developing geothermal energy sources for supporting the electrical system. This methodology (HDM) was applied to Oregon as a case study. The result of the data analysis in this research process is summarized in the following points:

1- The objective from the research study was to develop an assessment model framework that can be used for supporting cost effective renewable energy in Oregon by the development of geothermal energy sources. This research of study was done by using the HDM model and consisted of four levels: Mission, objectives, goals, and alternative.

2- Seven experts agreed to give their judgment and evaluate different nodes in objectives, goals, and alternatives.

3- The results of this research study were discussed with the experts to get their feedback, and learn from them what requirements are necessary for improvement in the geotechnical energy sector for future research. The experts agreed that this 
methodology is a good approach to help reach the right decision since this methodology (HDM) divides the problem into small sets, which will make the decision process easier. 


\section{CHAPTER 6: DISCUSSION}

This part will explain all of the data collection and the final results from the experts' participation in this research study, and analyzes the results according to the feedback from the experts. The discussion with the experts helped in understanding what drove their choices. This discussion provides insight and a better understanding of the participation results in this research study of geothermal energy sources in Oregon.

\subsection{Result Analysis}

The result of discussion analyses for objectives, goals, and alternatives from experts is explained below:

\subsubsection{Evaluation of the Objectives}

The HDM showed that minimizing environmental impact is the most important objective with respect to the mission of developing geothermal energy sources in Oregon. Reducing the expense of investment in geothermal energy projects was ranked second after minimizing environmental impact, and this result showed that for geothermal energy projects to be successful, it is important to reduce the investment cost. The more the cost of investment of geothermal energy projects is reduced, the faster improvement in technology will occur. Technical options improvement for geothermal energy projects and minimizing the negative impact on the general public had the same value and were ranked the third. Lastly, encouraging the community to support geothermal energy projects had the lowest value, and all these results were discussed with experts. 
Getting feedback from experts and analyzing the results from their participation showed the importance of having projects that focus on developing geothermal energy sources in Oregon, and benefit from improvement and progress in technology that serves this type of renewable energy. As mentioned above, minimizing the environmental impact and reducing the expense of investment in energy projects are the most important objectives, and the experts from different organizations explained why focusing on these objectives is important for the success of geothermal energy projects in Oregon. The results from the data collection from the survey showed that the experts preferred reducing the expense of investment in energy projects as the one of the most important objectives. Experts explained that the reason for this preference was that geothermal energy is still expensive and there is a lack of research in the field about how to create and benefit from improvements in this alternative energy form. This is the reason why geothermal energy projects are still expensive; there is not a huge amount of research available for developing the geothermal energy sources. Right now, geothermal energy research has problems with how to reach deep drilling at a cheaper cost. Meanwhile, researchers still have difficulties estimating how long the investment will last and how many additional funds will be required, so the experts found that the best thing to make geothermal energy projects successful is to focus on the economics of the projects because the price of other renewable energies like solar and wind are still cheaper. Experts also found that with new technology related to geothermal energy projects that the direction of the movement drill is going to be less expensive, so this is the reason why experts focused on the economical side of this research study for making geothermal energy projects successful. 
Minimizing environmental impact was ranked as the most important objective for developing geothermal energy sources in Oregon, and this result was discussed with the expert panel in order to clarify their preference for this objective. Experts found that environmental issues are important because Oregon has a strong environmental ethic at some sites. These sites are located on protected public land, especially some sites near volcanoes and others are located in national parks. In addition, public policy wants to keep Oregon away from any impact from poor water quality, chemical, and air pollution that can happen during the construction of geothermal energy projects. At the same time, experts encouraged investment in geothermal energy projects since geothermal energy is good for the environment compared with other sources of energy like the coal and oil industries. Geothermal energy is the best source of energy for both environmental and product of environment. There is much progress happening in the environmental sector. Oregon has achieved many things like working to have clean air and water, getting a healthy climate, working to have sustainable food, and making a beautiful landscape through reducing pollution. For these reasons, experts chose minimizing environmental impact as the most important objective.

Technical options improvement for geothermal energy projects was ranked as the third most important objective for developing geothermal energy sources in Oregon. Experts found that while there is still more effort needed for obtaining more improvements, the size of improvements is slow because the achievements in the field of geothermal energy are so expensive. To accelerate the size of improvement and to get more efficient system in the geothermal field, more support from government and public 
policy is required. Also, there are many failures that need to be fixed, such as the problem of heat transfer because a piece of equipment does not match the thermal properties during the construction, and this process of construction impacts system efficiency. In addition, the field of geothermal energy is still not as sophisticated as other alternative energy sources so the field of geothermal energy needs more attention and research to be competitive with other renewable energies like solar, wind, etc... The price of solar and wind are cheap compared with geothermal energy, which still expensive. Researchers are now focusing on developing low temperature geothermal sites, which carry a marginal cost. As the price of geothermal energy goes down, the prospective risk will go down too. For this reason, experts chose technical options improvement for geothermal energy projects as one of the most important objectives.

Minimizing the negative impact on the general public was ranked also the third the most important objectives for developing geothermal energy sources in Oregon. This result was discussed with experts for why they chose minimizing the negative impact on the general public as one of the important factors. Experts found that the success of any renewable energy project depends on the acceptance from the community who live around the construction of renewable energies projects. This is because ongoing operations of renewable energy create a large amount of waste. If these inconveniences to the community nearby the geothermal energy projects are during construction phase only, it may be easier to "sell" the idea of geothermal energy if the community knows the size of the benefit that will come from this project. If the issue is ongoing past the construction phase, the community nearby will terminate this project if they believe that 
the impact on their health will be negative. It is important to benefit from the technology available today since the technology works to serve the community, and while there are many improvements in this sector, the developers still need to be aware of these issues. For this reason, it is important to focus on minimizing the negative impact on the general public, and they need to work on changing the community's perception of geothermal energy sites or reduce these projects near communities.

Encouraging community to support geothermal energy projects was evaluated as the least importance objective for developing geothermal energy sources in Oregon. This result was discussed with the experts for why they chose encouraging community to support geothermal energy projects as the least importance factor. In fact, not all of the experts ranked encouraging community to support geothermal energy projects as the least valuable, some experts ranked it as second in importance, and some the third. The reason for disagreement about this value was that some experts considered geothermal energy as only one type of renewable energy, and that a community that is educated about the value of energy that can understand that renewable energy is beneficial to society, so this is the reason why the experts chose encouraging community support of geothermal energy as the lowest value. Some experts chose encouraging community to support geothermal energy projects as one of the important objectives. Those experts believe that is important to educate the community about geothermal projects, and people might express concern for environmental issues, therefore the process of educating the community about geothermal energy projects will hopefully over time create ongoing support and understanding about the process of geothermal energy and anything related to land use. 
People have very strong opinions about geothermal energy projects, and there are some challenges associated with geothermal energy projects or normal development that potentially can create a negative impact on the community. If people do not understand what the source of negative impact is or how it is caused, there may be a backlash that is disproportionate to the benefits of geothermal energy. People must understand that green projects are not always impact-free. For this reason, encouraging community to support geothermal energy projects is so important for successful investment in geothermal projects.

\subsubsection{Evaluation of the Goals}

The success of developing geothermal energy sources in Oregon requires knowing what are the most important objectives and goals. These objectives and goals will work with technology alternatives, and with this work will come greater improvements resulting in more successful geothermal energy projects. The HDM showed that minimizing noise and odor was ranked the most important goal with value 0.73. Creating new job opportunity was ranked as the second most important goal with value 0.59 , and minimizing capital cost was ranked the third with a value of 0.51 . The results of these goals were discussed with experts to ask why they ranked these goals as the most important.

Experts found that minimizing noise and odor are important because communities usually complain about noise, and although there are many types of geothermal plants, equipment still generates noise. Technology that accompanies geothermal energy projects is required for making equipment less noisy. There is a need for greater improvement in 
running the station smoothly so that it won't disturb the community nearby. If geothermal energy projects do not minimize noise and odor, geothermal energy sources will not improve, nor be accepted by local communities, which will keep geothermal energy limited to only a few sites. This is the reason why some experts chose minimizing noise and odor as the most important goal. Experts found also creating new job opportunity as one of the most important factors for successful geothermal energy projects in Oregon since geothermal projects will improve the economy, and more opportunity of jobs will be available for people. Meanwhile, more public dollars will be available, and job opportunity is beneficial in terms of economic and environmental value. Bringing these two things together from a public policy standpoint is beneficial for society as a whole. Geothermal energy projects need different job skills during discovering, construction, and maintenance after the completion of geothermal energy projects, and these skills are already exist. Staff can already do this kind of work, and this level of worker skill set leads to better and cleaner energy power.

Minimizing capital cost was found to be one of the most important goals chosen by the experts because the investment in geothermal energy projects is so expensive. Right now, most research on geothermal energy in Oregon focuses on low temperature geothermal projects since these projects are less expensive and require less funding than research focusing on high temperature geothermal projects. These high temperature projects require a lot of funding because the deep drilling needed for reaching high temperature projects will carry greater risk and may not find a good source of geothermal energy. For this reason, experts are more willing to find the best way to generate 
geothermal energy through the development of technology at a lower cost. The development of improved equipment manufacturing is in the middle of the most important goals because the experts found that there national laboratories are putting in a lot of effort to produce better equipment. Lately, many small manufacturing companies are merging with big companies. Even though big companies in U.S specialize in geothermal equipment, and are motivated to improve the equipment to be used in geothermal energy, the technology for updating the equipment and the systems in U.S is not the same as for the international market. The international market has created better improvements in geothermal equipment than U.S.

\subsubsection{Evaluation of Alternative}

The success of geothermal energy projects depends on developing the technology that works within the geothermal field to obtain greater benefits from alternative geothermal energy. The HDM showed that geothermal electricity was ranked the most important alternative with value 0.43 , direct use of geothermal heat was ranked the second importance alternative with value 0.31 , and GHP was ranked the least importance alternative with value 0.26 . These results were discussed with the experts to understand why they ranked the alternatives of geothermal energy the way that they did.

Geothermal electricity was ranked as the most important alternative for developing geothermal energy sources in Oregon. Experts explained that geothermal electricity was the most important resource for supplying more electricity to Oregon. At the same time, communities are increasing in population, and more new buildings are constructed as compared with previous years. Therefore, the growth of communities 
requires planning for a greater capacity of electricity. Also, having electricity generated from a geothermal field will not harm the environment, and it will bring a good amount of electricity to the community, and there are many places like Klamath Falls that already have geothermal electricity that is of great value. This is the reason why the experts encouraged the use of geothermal electricity to improve the geothermal field in Oregon.

Experts ranked direct use of geothermal heat as the second important alternative for developing geothermal energy sources in Oregon. Direct use of geothermal heat is considered the best option for economically, but it cannot work everywhere so direct use of geothermal heat is limited to certain geographic areas. Direct use for geothermal heat works well within a large building area but not within a small building area, and for this reason direct use of geothermal heat sources are only available as local resources for large buildings. At the same time, electric heat is often times less efficient or there are many heat applications that depend on natural gas. A huge amount of natural gas is used for heating applications, including industrial processes. For this reason, direct use of geothermal heat is more efficient, and can supply a large number of buildings with heating. Experts encouraged developing the direct use of geothermal heat because it is not only more efficient, it will also not harm the environment.

Geothermal Heat Pumps (GHP) was ranked the least importance alternative for developing geothermal energy sources in Oregon. The U.S. has a national history of failure in both the technical and the economic sector for using GHP .GHP is more in efficient homes that use a ductless heating system, but there is a problem with how to connect GHP with home buildings. Recently, GHP has become more successful in 
regulating temperature. While energy efficiency for the heat pump is going up, and the prices for the heat pump are going down, experts chose GHP as the least important alternative because GHP needs more research and professional geothermal experts to improve the technology to gain better efficiency from GHP.

\subsection{Challenges Accompanying with Geothermal Energy Projects}

Even though geothermal energy projects are a good investment, and are economically, politically, environmentally, technically, and socially beneficial, there are many challenges that still accompany geothermal energy from discovering sources and the construction of sites, to the continued maintenance of the sites after construction. In order to gain better efficiency from geothermal energy projects in Oregon, many improvements are required to expand the use of geothermal energy, and the process of improvement requires focusing on solving the obstacles that accompany geothermal fields, and these obstacles are explained below.

The cost of geothermal energy projects are still high as compared with other renewable energies like wind, solar, and so forth. Geothermal energy projects are considered expensive because even though the investors spend a huge amount of money for exploration and trying to locate right resources of geothermal energy, they may not get the right resources and may ultimately lose their investment. The problem of cost will be solved if researchers know how to find the right location, manage the exploration of resources, and estimate the drilling for required depth. Right now, many researchers are trying to find a critical plan for the resources of geothermal energy projects because the initial startup cost of an investment in the geothermal field is still high, and this scares 
many investors. For this reason, experts found that reducing the cost of investment in geothermal energy projects will generate more investors in this sector of renewable energy, and investment will also be cheaper when more researchers are available for the development of the geothermal energy.

Public relations and awareness are two of the biggest challenges because most people do not even know what geothermal energy is, and even when they told about geothermal energy, they do not think geothermal is necessary like solar, wind, etc.... At the same time, people are afraid of the seismic activity that can happen during the construction of geothermal projects because this issue is one of the factors that most needs to be heavily manage. For this reason, greater education and awareness are needed in the community to make them understand what are the benefits from geothermal projects, and to clarify the ways or methods that will be used to manage seismic activity if that happens during construction.

There is also a lack of information in the research of geothermal energy in Oregon as compared with California and Nevada. In addition, the level of professional people in Oregon is limited although good researchers are available at the Oregon Institute of Technology (OIT). Researchers still have difficulties in estimating the cost for long term investment. Oregon still needs more support to increase the progress in the technology for achieving a higher efficiency of geothermal energy projects.

Regulatory issues are one of the main factors that are holding geothermal energy back. Public policy works to protect the environment from any negative impact, so for 
this reason power of renewable policy over the long term is stronger in Oregon than California. As mentioned before, Oregon has strong environmental ethics, and these ethical issues prevent the development of research in the geothermal field since ethical considerations restrict the research and discovery of geothermal sources in some locations.

\subsection{Opportunity for Successful Geothermal Energy Projects in the Future}

Even though geothermal energy projects are accompanied by some obstacles that can make the improvement of the geothermal field very slow in Oregon, there are many opportunities to make the geothermal field successful especially with more progress in the research of geothermal energy technology. Oregon can take advantage of the research in the geothermal field to achieve more efficiency in this field of renewable energy, and have the opportunity for better improvement of geothermal energy projects in the future.

Oregon needs to focus on the economic prospective and support the adoption of geothermal energy projects with financial investment research, community outreach, and environmental protection. This support will make geothermal energy projects successful since the price of other renewable energies like solar, wind, etc., is still cheaper. For this reason, experts chose reducing the expense of investment in energy projects as one of the most important objectives in successful development of geothermal energy sources in

Oregon. In California, there is a lot of research done with deep drilling in the geothermal field, and this research will help Oregon. Right now, geothermal energy with technology today looks very good. Over the past few years, technology has improved within power plants, and geothermal energy is one of least expensive renewable energies if people are 
looking at the investment as a long term one. Researchers in geothermal field have done some recent work with Enhanced Geothermal System (EGS) in Oregon, and there are many attempts from researchers in geothermal field to produce big EGS. If big EGS happened, this good technology will be available in Oregon.

Compared with other states, Oregon is ready now for improvement, and Oregon is already an ideal spot for both direct use of geothermal heat and GHP. If technology develops a little bit better right now, the power production will be reliable as well. Now is the best time for developing geothermal energy sites, and working to manage the cost of geothermal energy. In addition, if the climate crisis continues, geothermal energy will be a good resource since additional resources will be required for reducing the negative impact on the climate, and geothermal energy sources are good candidate for solving this issue. It is important for Oregon to keep developing more research into geothermal energy sources to be ready for any crisis in the climate.

Researchers need support from public policy to be able to move forward. Encouraging new associations to participate in the research of geothermal energy sources is very important in Oregon, and all utilities are interested in geothermal energy projects that will lead to achieve full benefit from geothermal field in Oregon. 


\section{CHAPTER 7: RESEARCH SCOPE, ASSUMPTIONS AND LIMITATIONS, EXPECTED CONTRIBUTIONS, FUTURE RESEARCH}

\subsection{Assumptions and Limitations of the Research Model}

A number of expert panelists who have the knowledge to and who can supply the data validation of the outcome will contribute to building and evaluating the research model. This process of evaluation will have positive impact on the development of the model because the model will be more accurate in the decision-making process. In addition, there are many other factors that can be used to improve the research model. These factors contribute in different ways: relevant expertise within the research area, the availability and willingness to participate, and balanced perspectives and biases. All of these factors were discussed in the previous chapters. Even though these factors are important and must be applied and used in the panel to have an accurate outcome, it is still a challenge to generate the best result without biases. For solving this process of uncertainty in the decision making, different procedures and methods will be used in the research model to create validity measures. All of this process for this research study was discussed in previous chapters. Using suitable tools and techniques, and selecting the right experts to provide feedback will reduce the ambiguity in some parts of the research. Having accurate information will lead to different perspectives for better decision making.

In general, the outcome of the research model is dependent on the context and is time dependent. That means any change in the future in terms of any driver: technical, economic, and the social, political, and environmental sectors, will have a large effect on the electrical system. In addition, any change will be impacted by the changes in the 
utility goals and objectives, which are represented by the decisions made about the development of geothermal energy resource alternatives in Oregon. From this, it is clear that it's hard to predict future changes, and this affects in the decision- making process.

The value of geothermal energy resources relies on the market, technology, and the variability of utility available in Oregon. For example, the demand for geothermal energy in the market is not stable, and that is because of many factors like the availability of suitable technology that contributes to use the source of geothermal energy, and the price of using source of geothermal as compare with other energy sources. All of these factors participate in changing the value of geothermal energy in the market. In addition, these factors can change at any time. For example, the value of geothermal energy resources will not be the same area to area. When the research model applies the process to another region other than Oregon, the decision -making process will be significantly different. It is clear that the research model was created to support the electrical system in Oregon. The research model can be developed and used in other regions by changing it according to the market requirements, available technology, utilities, and the possibility for success. Finally, the research model can be applied at all types of geothermal electricity planets (dry steam, flash steam, and binary).These types of geothermal electricity were discussed in the previous chapters on the comparisons of which technology is the best for generating electricity. Unlike the previously mentioned technologies, the research model works to support the electrical system through depending on the geothermal process that uses the heat pump, direct use of heat, and generating electricity. 


\subsection{Expected Contributions}

The expected contribution of the research model will lead to better knowledge and more accuracy in the decision- making process. The following steps outline expected project contributions. First, the research model will contribute to the evaluation of geothermal energy resource alternatives with respect to the effect on the utility objectives and goals. From the literature review, it is clear that no research model can work with more than one dimension (economic, technical, social, political, and environment) and go in details for each aspect (utility objective and goals). Utility objectives and goals are very important in the process of decision making because they constitute the variables in the research model, which requires a tradeoff in the analysis of decision process. This tradeoff makes decisions easy to take in the field. In addition, the literature review showed that it's important to have diversity in the use of geothermal energy resources in different applications as was mentioned in the previous chapters. The literature review also showed the effect of this diversity in terms of supporting the electrical system, and how the successful use of technologies and alternative sources of geothermal energy in different regions in the world can also be successfully used in Oregon. From the literature, it is important to have a connection between utility objectives and goals for geothermal energy resource alternatives, as this will increase the level of knowledge and understanding for creating accurate decisions in the field, and to gain greater benefits from geothermal energy sources.

The HDM model is important to use for finding which geothermal energy resource alternative is the best with respect to utility objectives and goals. The HDM method 
depends on judgments that require increased knowledge and understanding of the important criteria in the decision- making process, and to provide feedback from the experts to generate a more accurate decision. The HDM method has the ability to deal with multiple perspectives and to analyze each perspective with respect to utility objectives and goals, which helps in obtaining a better decision.

The decision to use alternative sources of geothermal energy is a good investment, and the probability of success is very high if these types of projects are considered a longterm investment. There are many criteria (technical, environmental, social, economic, and political) that are changing with the times that will have an impact on these types of investments over the long term. It will require a recalculation and updating of the materials and equipment that are used in these investments, which will have an impact on the whole electrical system.

In general, the research model will contribute to an increased level of knowledge for using geothermal energy resource alternatives, and to know which decision is suitable for reaching the full benefit from this source of energy. In addition, the research model will help to build the right structures for developing a strategy that will improve the decisionmaking process. The outcome from the model will be the best way to support the electrical system in Oregon.

\subsection{Future Research}

This research study focuses on the use of one of the alternative sources of geothermal energy for supporting electrical system. The purpose of this case study is to evaluate the 
electrical system in Oregon because of the many criteria that has been already discussed in the previous chapters. The Hierarchical Decision Model (HDM) method was used for this purpose. This method has the ability to expand the research because this method depends on the collection of information from the literature review. In addition, this information increases the ability to know what the requirements are for developing the model in future research because our case study is about the state of Oregon. The requirements for developing geothermal energy alternatives in this state are different from other regions, and all of the used utility objectives and goals are for Oregon. There is no guarantee that these utility objectives and goals can be successful if applied to other locations around the world for supporting electrical systems because not everything that we found in the literature can be successfully used in Oregon. The utility objectives and goals in the research model are matched with the requirements for development of geothermal energy resources in Oregon. The research model can be improved for use in future research for other regions, and from this research model one can look for what is not necessary, what is missing, and what is required to keep from the criteria that was used in the Oregon case study.

The research model may or may not change in future work because this research was built with the dependence on the current research from the literature review and the current market and end use. That means the utility objectives and goals can change, and the selection of geothermal energy resources alternatives can change depending on the technology available in the market and the diffusion of end use. 
For future research, it is important to create a diversity of scenarios to look at how each scenario interacts in the research model, how this impacts the utility objectives and goals, and what is the outcome from the process of scenario analysis in the decisionmaking process. From that, scenario analysis is necessary to calculate the impact for future work, and the importance of the analysis for each scenario creates a better development of the model. The development of the model will be perfected if the scenarios are discussed with the experts to know which criteria are necessary for the development of the model, and from this information reach the best outcome for the end use, which the improvement of the electrical system in Oregon.

Sensitivity Analysis is necessary in the research model for understanding better decision choices according to the utility goals and objectives. This will help to create different scenarios for future planning, and will help to estimate the best way to deal with each scenario if it is applied in the real world, and what the outcome will be based on the chosen decision.

The research model can be connected with an optimization program for gaining the best benefits from geothermal energy resources as output for future research. 


\section{REFERENCES}

[1] S. Xilin, "Study on the feasibility of bioenergy development in China," In Information Management, Innovation Management and Industrial Engineering (ICIII), 2011 International Conference, vol. 1, pp. 136-141, 2011.

[2] H. Farzaneh, and M. Dashti, "Integrated modeling framework for optimizing energy demand in high energy intensive industries of Iran," In Energy Conference and Exhibition (EnergyCon), 2010 IEEE International, pp. 780-784, 2010.

[3] R.Knorr, "Design criteria and levelized costs of electricity for photovoltaic power plants at different global locations," In Systems, Signals and Devices (SSD), 2012 9th International Multi-Conference, pp. 1-6, 2012.

[4] W. Bach and W.H.Matthews, " Exploring alternative energy strategies," Proceedings of a Conference on Non-Fossil Fuel and Non-Nuclear Fuel Energy Strategies, vol.4, no.5, pp.711-722, October 1979.

[5] A.M.Weinberg, " Are the alternative energy strategies achievable?," Proceedings of a Conference on Non-Fossil Fuel and Non-Nuclear Fuel Energy Strategies, vol.4, no.5, pp.941-951, October 1979.

[6] C.J.Ryan, " The choices in the next energy and social revolution," Technological Forecasting and Social Change, vol.16, no.3, pp.191-208, March 1980.

[7] E.H.Warren, " Solar energy market penetration models: Science or number mysticism?, " Technological Forecasting and Social Change, vol. 16, no. 2, pp.105-118, February 1980.

[8] J.R.Burns, "' Solar energy and the national energy dilemma: A model for policy evaluation," Technological Forecasting and Social Change, vol. 21, no. 3, pp.213-228, June 1982.

[9] S.W.Sawyer, "'Leaders in change: Solar energy owners and the implications for future adoption rates," Technological Forecasting and Social Change, vol.21, no.3, pp.201-211, June 1982.

[10] F.Beck and E.Martinot, "Renewable energy policies and barriers". Encyclopedia of Energy, vol. 5, no. 7, pp. 365-383, 2004. 
[11] W.Zhe, W. Yiru, H. Chuan, Y. Jianhui, and Z. Hao. "Development status of China's renewable energy power generation," In Sustainable Power Generation and Supply, 2009. SUPERGEN'09. International Conference, pp. 1-5, 2009.

[12] R.H.Wiser and S.J.Pickle, " Financing investments in renewable energy : the impacts of policy design," Renewable and Sustainable Energy Reviews, vol.2, No. 4, pp.361-386, December 1998.

[13] R.DiPippo, "Geothermal energy electricity generation and environmental impact," Energy Policy, vol. 19, no.8, pp.798-807, October 1991.

[14] Energy.gov, 'Geothermal | Department of Energy', 2015. [Online]. Available: http://www.energy.gov/science-innovation/energy-sources/renewableenergy/geothermal. [Accessed: 25- Jun- 2015].

[15] E.Barbier, "Geothermal energy technology and current status: an overview," Renewable and Sustainable Energy Reviews, vol. 6, no.1, pp.3-65, 2002.

[16] Oregon.gov, 'Geothermal Energy Geothermal Energy', 2015. [Online]. Available: http://www.oregon.gov/energy/renew/geothermal/pages/geo_index.aspx. [Accessed: 25- Jun- 2015].

[17] Union of Concerned Scientists, 'How Geothermal Energy Works', 2015. [Online]. Available: http://www.ucsusa.org/clean_energy/our-energy-choices/renewableenergy/how-geothermal-energy-works.html\#.VYukZ_lVikp. [Accessed: 25- Jun2015].

[18] Lsa.colorado.edu, 'Geothermal Energy', 2015. [Online]. Available: http://lsa.colorado.edu/essence/texts/geothermal.html. [Accessed: 25- Jun- 2015].

[19] R.Bertani, "World geothermal power generation in the period 2001-2005," Geothermics, vol. 34, no. 6, pp. 651-690, December 2005.

[20] R.Bertani, "Geothermal power generation in the world 2005-2010 update report," Geothermics, vol. 41, pp.1-29, January 2012.

[21] "2013 Annual US Geothermal Power Production and Development Report", Geothermal Energy Association, Washington, D.C, 2013.

[22] J.W.Lund, "Direct-use of geothermal energy in the USA" Applied Energy, vol. 74, no. 1, pp. 33-42, January 2003. 
[23] J.W.Lund, "Geothermal research at the Geo-Heat Center Oregon Institute of Technology," In Energy Conversion Engineering Conference, 1997. IECEC-97., Proceedings of the 32nd Intersociety, vol. 3, pp. 1820-1825, 1997.

[24] J.W.Lund and D. H. Freeston, "World-wide direct uses of geothermal energy 2000," Geothermics, vol. 30, no. 1, pp.29-68, February 2001.

[25] Eia.gov, 2015. [Online]. Available: http://www.eia.gov/state/analysis.cfm?sid=OR. [Accessed: 25- Jun- 2015].

[26] U.S.Department of Energy,'” EERE Investments in Oregon,'”2013.

[27] S.Petty, Y. Nordin, W. Glassley, T. T. Cladouhos, and M. Swyer, "Improving geothermal project economics with multi-zone stimulation: results from the Newberry Volcano EGS demonstration," In Proceedings of the 38th Workshop on Geothermal Reservoir Engineering, Stanford, CA, pp. 11-13, February 2013.

[28] D.A.Hull, R. G. Bowen, D. D. Blackwell, and N. V. Peterson, "Preliminary HeatFlow Map and Evaluation of Oregon's Geothermal Energy Potential," The Ore Bin, vol. 39, no. 7, pp.109-123, July 1977.

[29] S.D.Pohekar, and M. Ramachandran, "Application of multi-criteria decision making to sustainable energy planning - a review," Renewable and sustainable energy reviews, vol. 8, no. 4, pp.365-381, August 2004.

[30] J.J.Wang, Y.Y. Jing, C.F. Zhang, and J.H. Zhao, "Review on multi-criteria decision analysis aid in sustainable energy decision-making," Renewable and Sustainable Energy Reviews, vol. 13, no. 9, pp.2263-2278, December 2009.

[31] E.Løken, "Use of multicriteria decision analysis methods for energy planning problems," Renewable and Sustainable Energy Reviews, vol. 11, no. 7, pp.15841595, September 2007.

[32] G.A.Mendoza, and H. Martins, "Multi-criteria decision analysis in natural resource management: a critical review of methods and new modelling paradigms," Forest ecology and management, vol. 230, no. 1, pp. 1-22, July 2006.

[33] 'Energy Challenges for Oregon and the Nation", National Ocean Industrial Association.

[34] S. Adams and S. Anderson, 'Portland Plan', City of Portland Bureau of Planning and Sustainability, Portland, 2009. 
[35] "State of Oregon Biennial Energy Plan 2015-2017", Oregon Department of Energy, Salem, Oregon, 2015.

[36] J.E.Samouilidis, and C. S. Mitropoulos, "An aggregate model for energy costs: national product interdependence," Energy Economics, vol. 4, no. 3, pp.199-206, July 1982.

[37] A.Bopp, and G. M. Lady, "On measuring the effects of higher energy prices," Energy Economics, vol. 4, no. 4, pp.218-224, October 1982.

[38] P.Meier, and V. Mubayi, "Modelling energy-economic interactions in developing countries: A linear programming approach," European Journal of Operational Research, vol. 13, no. 1, pp.41-59, May 1983.

[39] M.Beccali, M. Cellura, and M. Mistretta, "Decision-making in energy planning. Application of the Electre method at regional level for the diffusion of renewable energy technology," Renewable Energy, vol. 28, no. 13, pp.2063-2087, October 2003.

[40] J.R.San Cristóbal, "Multi-criteria decision-making in the selection of a renewable energy project in Spain: the Vikor method," Renewable energy, vol. 36, no. 2, pp.498-502, February 2011.

[41] T.Kaya, and C. Kahraman, "Multicriteria decision making in energy planning using a modified fuzzy TOPSIS methodology," Expert Systems with Applications, vol. 38, no. 6, pp.6577-6585, June 2011.

[42] M.Beccali, M. Cellura, and D. Ardente, "Decision making in energy planning: the ELECTRE multicriteria analysis approach compared to a fuzzy-sets methodology," Energy Conversion and Management, vol. 39, no. 16, pp.18691881, November 1998.

[43] P.Zhou, B. W. Ang, and K. L. Poh, "Decision analysis in energy and environmental modeling: An update," Energy, vol. 31, no. 14, pp.2604-2622, November 2006.

[44] R.C.Lind, "Intergenerational equity, discounting, and the role of cost-benefit analysis in evaluating global climate policy," Energy Policy, vol. 23, no. 4, pp.379-389, April 1995.

[45] D.Maddison, "A cost-benefit analysis of slowing climate change," Energy policy, vol. 23, no. 4, pp.337-346, April 1995. 
[46] D.Diakoulaki, and F. Karangelis, "Multi-criteria decision analysis and costbenefit analysis of alternative scenarios for the power generation sector in Greece," Renewable and Sustainable Energy Reviews, vol. 11, no. 4, pp. 716-727, May 2007.

[47] B.Snyder, and M. J. Kaiser, "Ecological and economic cost-benefit analysis of offshore wind energy," Renewable Energy, vol. 34, no. 6, pp.1567-1578, June 2009.

[48] A.B.Jaffe, R. G. Newell, and R. N. Stavins, "A tale of two market failures: Technology and environmental policy," Ecological economics, vol. 54, no. 2, pp.164-174, August 2005.

[49] J.P.Clinch, and J. D. Healy, "Cost-benefit analysis of domestic energy efficiency," Energy Policy, vol. 29, no. 2, pp.113-124, January 2001.

[50] J.Bollen, B. van der Zwaan, C. Brink, and H. Eerens, "Local air pollution and global climate change: A combined cost-benefit analysis," Resource and Energy Economics, vol. 31, no. 3, pp.161-181, August 2009.

[51] M.Molinos-Senante, F. Hernández-Sancho, and R. Sala-Garrido, "Cost-benefit analysis of water-reuse projects for environmental purposes: a case study for Spanish wastewater treatment plants," Journal of Environmental Management, vol. 92, no. 12, pp.3091-3097, December 2011.

[52] S.Mehta, and C. Shahpar, "The health benefits of interventions to reduce indoor air pollution from solid fuel use: a cost-effectiveness analysis," Energy for sustainable development, vol. 8, no. 3, pp.53-59, September 2004.

[53] V. Kovacevic, and J. Wesseler, "Cost-effectiveness analysis of algae energy production in the EU," Energy Policy, vol. 38, no. 10, pp.5749-5757, October 2010.

[54] A.M.Bassi, and J. S. Yudken, "Climate policy and energy-intensive manufacturing: A comprehensive analysis of the effectiveness of cost mitigation provisions in the American Energy and Security Act of 2009," Energy Policy, vol. 39, no. 9, pp. 4920-4931, September 2011.

[55] T.Jackson, "Joint implementation and cost-effectiveness under the Framework Convention on Climate Change," Energy policy, vol. 23, no. 2, pp.117-138, February 1995. 
[56] G.Berndes, and J.Hansson, "Bioenergy expansion in the EU: cost-effective climate change mitigation, employment creation and reduced dependency on imported fuels," Energy Policy, vol. 35, no. 12, pp. 5965-5979, December 2007.

[57] R.J.Zomer, A. Trabucco, D. A. Bossio, and L. V. Verchot, "Climate change mitigation: A spatial analysis of global land suitability for clean development mechanism afforestation and reforestation," Agriculture, ecosystems \& environment, vol. 126, no. 1, pp.67-80, June 2008.

[58] D.B.Nelson, M. H. Nehrir, and C. Wang, "Unit sizing and cost analysis of standalone hybrid wind/PV/fuel cell power generation systems," Renewable energy, vol. 31, no. 10, pp.1641-1656, August 2006.

[59] S.Carley, "State renewable energy electricity policies: An empirical evaluation of effectiveness," Energy policy, vol. 37, no. 8, pp. 3071-3081, August 2009.

[60] J.Kneifel, "Life-cycle carbon and cost analysis of energy efficiency measures in new commercial buildings," Energy and Buildings, vol. 42, no. 3, pp.333-340, March 2010.

[61] M.Amann, I. Bertok, J. Borken-Kleefeld, J. Cofala, C. Heyes, L. HöglundIsaksson, Z. Klimont et al, "Cost-effective control of air quality and greenhouse gases in Europe: Modeling and policy applications," Environmental Modelling \& Software, vol. 26, no. 12, pp.1489-1501, December 2011.

[62] B.Stevens, and A. Rose, "A dynamic analysis of the marketable permits approach to global warming policy: A comparison of spatial and temporal flexibility," Journal of environmental economics and management, vol. 44, no. 1, pp.45-69, July 2002.

[63] W.R.Morrow, K. S. Gallagher, G. Collantes, and H. Lee, "Analysis of policies to reduce oil consumption and greenhouse-gas emissions from the US transportation sector," Energy Policy, vol. 38, no. 3, pp.1305-1320, March 2010.

[64] B.Vermont, and S. De Cara, "How costly is mitigation of non-CO 2 greenhouse gas emissions from agriculture?: A meta-analysis," Ecological Economics, vol. 69, no. 7, pp. 1373-1386, May 2010.

[65] B.Agrawal, and G. N. Tiwari, "Life cycle cost assessment of building integrated photovoltaic thermal (BIPVT) systems," Energy and Buildings, vol. 42, no. 9, pp.1472-1481, September 2010. 
[66] A.Chel, G. N. Tiwari, and A. Chandra, "Simplified method of sizing and life cycle cost assessment of building integrated photovoltaic system," Energy and Buildings, vol. 41, no. 11, November 2009.

[67] A.J.Marszal, and P. Heiselberg, "Life cycle cost analysis of a multi-storey residential net zero energy building in Denmark," Energy, vol. 36, no. 9, pp.56005609, September 2011.

[68] J.Basbagill, F. Flager, M. Lepech, and M. Fischer, "Application of life-cycle assessment to early stage building design for reduced embodied environmental impacts," Building and Environment, vol. 60, pp.81-92, February 2013.

[69] M.Erlandsson, and M. Borg, "Generic LCA-methodology applicable for buildings, constructions and operation services - today practice and development needs," Building and environment, vol. 38, no. 7, pp.919-938, July 2003.

[70] Z.Hu, F. Fang, D. Ben, G. Pu, and C. Wang, "Net energy, CO 2 emission, and life-cycle cost assessment of cassava-based ethanol as an alternative automotive fuel in China," Applied Energy, vol. 78, no. 3, pp.247-256, July 2004.

[71] S.Papong, and P. Malakul, "Life-cycle energy and environmental analysis of bioethanol production from cassava in Thailand," Bioresource technology, vol. 101, no. 1, pp. S112-S118, January 2010.

[72] P.Gluch, and H. Baumann, "The life cycle costing (LCC) approach: a conceptual discussion of its usefulness for environmental decision-making," Building and environment, vol. 39, no. 5, pp.571-580, May 2004.

[73] I.B.Utne, "Improving the environmental performance of the fishing fleet by use of Quality Function Deployment (QFD)," Journal of Cleaner Production, vol. 17, no. 8, pp. 724-731, May 2009.

[74] B.Ness, E. Urbel-Piirsalu, S. Anderberg, and L. Olsson, "Categorising tools for sustainability assessment," Ecological economics, vol. 60, no. 3, pp.498-508, January 2007.

[75] L.Luo, E. Van Der Voet, and G. Huppes, "Life cycle assessment and life cycle costing of bioethanol from sugarcane in Brazil," Renewable and Sustainable Energy Reviews, vol. 13, no. 6, pp.1613-1619, August 2009. 
[76] I.B.Utne, "Life cycle cost (LCC) as a tool for improving sustainability in the Norwegian fishing fleet," Journal of cleaner production, vol. 17, no. 3, pp.335344, February 2009.

[77] T.L.T.Nguyen, S. H. Gheewala, and S. Garivait, "Energy balance and GHGabatement cost of cassava utilization for fuel ethanol in Thailand," Energy Policy, vol. 35, no. 9, pp.4585-4596, September 2007.

[78] L.Reijnders, and M.A. Huijbregts, "Life cycle greenhouse gas emissions, fossil fuel demand and solar energy conversion efficiency in European bioethanol production for automotive purposes," Journal of cleaner production, vol. 15, no. 18, pp.1806-1812, December 2007.

[79] X.Yan, and R. J. Crookes, "Life cycle analysis of energy use and greenhouse gas emissions for road transportation fuels in China," Renewable and Sustainable Energy Reviews, vol. 13, no. 9, pp.2505-2514, December 2009.

[80] O.O.Ugwu, M. M. Kumaraswamy, F. Kung, and S. T. Ng, "Object-oriented framework for durability assessment and life cycle costing of highway bridges," Automation in construction, vol. 14, no. 5, pp.611-632, October 2005.

[81] S.González-García, D. Iribarren, A. Susmozas, J. Dufour, and R. J. Murphy, "Life cycle assessment of two alternative bioenergy systems involving Salix spp. biomass: Bioethanol production and power generation," Applied Energy, vol. 95, pp.111-122, July 2012.

[82] K.Knapp, and T. Jester, "Empirical investigation of the energy payback time for photovoltaic modules," Solar Energy, vol. 71, no. 3, pp.165-172, 2001.

[83] J.Peng, L. Lu, and H. Yang, "Review on life cycle assessment of energy payback and greenhouse gas emission of solar photovoltaic systems," Renewable and Sustainable Energy Reviews, vol. 19, pp.255-274, 2013.

[84] M.J.de Wild-Scholten,"Energy payback time and carbon footprint of commercial photovoltaic systems," Solar Energy Materials and Solar Cells, vol. 119, pp.296305, December 2013.

[85] R.Wilson, and A. Young, "The embodied energy payback period of photovoltaic installations applied to buildings in the UK," Building and Environment, vol. 31, no. 4, pp.299-305, July 1996. 
[86] M.Goe, and G. Gaustad, "Strengthening the case for recycling photovoltaics: An energy payback analysis," Applied Energy, vol. 120, pp.41-48, July 2014.

[87] D.Weißbach, G. Ruprecht, A. Huke, K. Czerski, S. Gottlieb, and A. Hussein, "Energy intensities, EROIs (energy returned on invested), and energy payback times of electricity generating power plants," Energy, vol. 52, pp.210-221, April 2013.

[88] L.Gagnon, C.Belanger, and Y. Uchiyama, "Life-cycle assessment of electricity generation options: the status of research in year 2001," Energy policy, vol. 30, no. 14, pp.1267-1278, November 2002.

[89] S.W.White, and G. L. Kulcinski, "Birth to death analysis of the energy payback ratio and $\mathrm{CO} 2$ gas emission rates from coal, fission, wind, and DT-fusion electrical power plants," Fusion Engineering and Design, vol. 48, no. 3, pp.473481, September 2000.

[90] L.Schleisner, "Life cycle assessment of a wind farm and related externalities," Renewable energy, vol. 20, no. 3, pp.279-288, July 2000.

[91] L.Lu, and H. X. Yang, "Environmental payback time analysis of a roof-mounted building-integrated photovoltaic (BIPV) system in Hong Kong," Applied Energy, vol. 87, no. 12, pp.3625-3631, December 2010.

[92] F.Ardente, G. Beccali, M. Cellura, and V. L. Brano, "Life cycle assessment of a solar thermal collector: sensitivity analysis, energy and environmental balances," Renewable Energy, vol. 30, no. 2, pp.109-130, February 2005.

[93] Y. Hang, M. Qu, and F. Zhao, "Economic and environmental life cycle analysis of solar hot water systems in the United States," Energy and Buildings, vol. 45, pp.181-188, February 2012.

[94] I.L.Wong, P. C. Eames, and R. S. Perera, "A review of transparent insulation systems and the evaluation of payback period for building applications," Solar Energy, vol. 81, no. 9, pp.1058-1071, September 2007.

[95] J. C. Chilton, G. G. Maidment, D. Marriott, A. Francis, and G. Tobias, "Case study of a rainwater recovery system in a commercial building with a large roof," Urban water, vol. 1, no. 4, pp.345-354, December 2000. 
[96] N. Daouas, Z. Hassen, and H. B. Aissia, "Analytical periodic solution for the study of thermal performance and optimum insulation thickness of building walls in Tunisia," Applied Thermal Engineering, vol. 30, no. 4, March 2010.

[97] J.N.Hacker, T. P. De Saulles, A. J. Minson, and M. J. Holmes, "Embodied and operational carbon dioxide emissions from housing: a case study on the effects of thermal mass and climate change," Energy and Buildings, vol. 40, no. 3, pp.375$384,2008$.

[98] I.Staffell, A. Ingram, and K. Kendall, "Energy and carbon payback times for solid oxide fuel cell based domestic CHP," International journal of hydrogen energy, vol. 37, no. 3, pp.2509-2523, February 2012.

[99] Y.J.Kim, and G. L. Sanders, "Strategic actions in information technology investment based on real option theory," Decision Support Systems, vol. 33, no. 1, pp.1-11, May 2002.

[100] B.C. McLellan, G. D. Corder, D. Giurco, and S. Green, "Incorporating sustainable development in the design of mineral processing operations-Review and analysis of current approaches," Journal of Cleaner Production, vol. 17, no. 16, pp.1414-1425, November 2009.

[101] F.Kjaerland,"A real option analysis of investments in hydropower-The case of Norway," Energy Policy, vol. 35, no. 11, pp.5901-5908, November 2007.

[102] S.C. Lee, "Using real option analysis for highly uncertain technology investments: The case of wind energy technology," Renewable and Sustainable Energy Reviews, vol. 15, no. 9, pp. 4443-4450, December 2011.

[103] K.T. Yeo, and F. Qiu, "The value of management flexibility — a real option approach to investment evaluation," International Journal of Project Management, vol. 21, no. 4, pp.243-250, May 2003.

[104] G.A. Davis, and B. Owens, "Optimizing the level of renewable electric R\&D expenditures using real options analysis," Energy Policy, vol. 31, no. 15, pp.15891608, December 2003.

[105] G. Kumbaroğlu, R.Madlener, and M. Demirel, "A real options evaluation model for the diffusion prospects of new renewable power generation technologies," Energy Economics, vol. 30, no. 4, pp.1882-1908, July 2008. 
[106] J.Szolgayova, S. Fuss, and M. Obersteiner, "Assessing the effects of CO 2 price caps on electricity investments - a real options analysis," Energy Policy, vol. 36, no. 10, pp.3974-3981, October 2008.

[107] A.Jalil, and S. F. Mahmud, "Environment Kuznets curve for CO 2 emissions: a cointegration analysis for China," Energy Policy, vol. 37, no. 12, pp.5167-5172, December 2009.

[108] K.D. Miller, and H. G. Waller, "Scenarios, real options and integrated risk management," Long range planning, vol. 36, no. 1, pp.93-107, February 2003.

[109] D.M. Lander, and G. E. Pinches, "Challenges to the practical implementation of modeling and valuing real options," The quarterly review of economics and finance, vol. 38, no. 3, pp.537-567, 1998.

[110] J.Kim, M. Hwang, D.H. Jeong, and H. Jung, "Technology trends analysis and forecasting application based on decision tree and statistical feature analysis," Expert Systems with Applications, vol. 39, no. 16, pp.12618-12625, November 2012.

[111] A.D. Hawkes, and M. A. Leach, "Cost-effective operating strategy for residential micro-combined heat and power," Energy, vol. 32, no. 5, pp.711-723, May 2007.

[112] G.K. Tso, and K. K. Yau, "Predicting electricity energy consumption: A comparison of regression analysis, decision tree and neural networks," Energy, vol. 32, no. 9, pp.1761-1768, September 2007.

[113] D.Weiner, D. Fisher, E. J. Moses, B. Katz, and G. Meron, "Operation experience of a solar-and wind-powered desalination demonstration plant," Desalination, vol. 137, no. 1, pp.7-13, May 2001.

[114] S.C. Lee, and L.H. Shih, "Renewable energy policy evaluation using real option model-The case of Taiwan," Energy Economics, vol. 32, pp.S67-S78, September 2010.

[115] M. Biswal, and P. K. Dash, "Detection and characterization of multiple power quality disturbances with a fast S-transform and decision tree based classifier," Digital Signal Processing, vol. 23, no. 4, pp.1071-1083, July 2013.

[116] G.M. Cramer, R. A. Ford, and R. L. Hall, "Estimation of toxic hazard-a decision tree approach," Food and cosmetics toxicology, vol. 16, no. 3, pp.255276, 1976. 
[117] R. Duncan, "What is the right organization structure? Decision tree analysis provides the answer," Organizational Dynamics, vol. 7, no. 3, pp.59-80, Winter 1980.

[118] Z. Yu, F. Haghighat, B. C. Fung, and H. Yoshino, "A decision tree method for building energy demand modeling," Energy and Buildings, vol. 42, no. 10, pp.1637-1646, October 2010.

[119] C.Olaru, and L. Wehenkel, "A complete fuzzy decision tree technique," Fuzzy sets and systems, vol. 138, no. 2, pp.221-254, September 2003.

[120] V.A. Varma, G. V. Reklaitis, G. E. Blau, and J. F. Pekny, "Enterprise-wide modeling \& optimization-An overview of emerging research challenges and opportunities," Computers \& Chemical Engineering, vol. 31, no. 5, pp.692-711, May 2007.

[121] S.W.Wallace, and S.E. Fleten, "Stochastic programming models in energy," Handbooks in operations research and management science, vol. 10, pp.637-677, 2003.

[122] M. Pehnt, "Dynamic life cycle assessment (LCA) of renewable energy technologies," Renewable energy, vol. 31, no. 1, pp.55-71, January 2006.

[123] B.T.Liu, K.H. Chien, and C.C. Wang, "Effect of working fluids on organic Rankine cycle for waste heat recovery," Energy, vol. 29, no. 8, pp.1207-1217, June 2004.

[124] D.Reiche, and M. Bechberger, "Policy differences in the promotion of renewable energies in the EU member states," Energy policy, vol. 32, no. 7, pp.843-849, May 2004.

[125] G.Walker, and P.Devine-Wright, "Community renewable energy: What should it mean?," Energy policy, vol. 36, no. 2, pp.497-500, February 2008.

[126] Z.Yu, B. C. Fung, F. Haghighat, H. Yoshino, and E. Morofsky, "A systematic procedure to study the influence of occupant behavior on building energy consumption," Energy and Buildings, vol. 43, no. 6, pp.1409-1417, June 2011.

[127] B.C.Richardson, "Sustainable transport: analysis frameworks," Journal of Transport Geography, vol. 13, no. 1, pp.29-39, March 2005. 
[128] H.Lund, and G. Salgi, "The role of compressed air energy storage (CAES) in future sustainable energy systems," Energy Conversion and Management, vol. 50, no. 5, pp.1172-1179, May 2009.

[129] H.Lund, "Large-scale integration of wind power into different energy systems," Energy, vol. 30, no. 13, pp.2402-2412, October 2005.

[130] R.Keeney, and H. Raiffa, "Decisions with Multiple Objectives: Preferences and Value Tradeoffs. New York: Willey, 1976.

[131] A. Sanayei, S. F. Mousavi, M. R. Abdi, and A. Mohaghar, "An integrated group decision-making process for supplier selection and order allocation using multiattribute utility theory and linear programming," Journal of the Franklin Institute, vol. 345, no. 7, pp.731-747, October 2008.

[132] U.Bose, A. M. Davey, and D. L. Olson, "Multi-attribute utility methods in group decision making: past applications and potential for inclusion in GDSS," Omega, vol. 25, no. 6, pp.691-706, December 1997.

[133] R.L.Keeney, "The art of assessing multiattribute utility functions," Organizational behavior and human performance, vol. 19, no. 2, pp.267-310, August 1977.

[134] J. Ananda, and G. Herath, "Evaluating public risk preferences in forest land-use choices using multi-attribute utility theory," Ecological Economics, vol. 55, no. 3, pp.408-419, November 2005.

[135] S.H.Zanakis, A. Solomon, N. Wishart, and S. Dublish, "Multi-attribute decision making: A simulation comparison of select methods," European journal of operational research, vol. 107, no. 3, pp.507-529, June 1998.

[136] P.Konidari, and D. Mavrakis, "A multi-criteria evaluation method for climate change mitigation policy instruments," Energy Policy, vol. 35, no. 12, pp.62356257, December 2007.

[137] G.D. Holt, "Which contractor selection methodology?," International Journal of project management, vol. 16, no. 3, pp.153-164, June 1998.

[138] Z.Pawlak, and R. Sowinski, "Rough set approach to multi-attribute decision analysis," European Journal of Operational Research, vol. 72, no. 3, pp.443-459, February 1994. 
[139] Y.Kainuma, and N. Tawara, "A multiple attribute utility theory approach to lean and green supply chain management," International Journal of Production Economics, vol. 101, no. 1, pp.99-108, May 2006.

[140] K.Kowalski, S. Stagl, R. Madlener, and I. Omann, "Sustainable energy futures: Methodological challenges in combining scenarios and participatory multi-criteria analysis," European Journal of Operational Research, vol. 197, no. 3, pp.10631074, September 2009.

[141] G.Anandalingam, and C. E. Olsson, "A multi-stage multi-attribute decision model for project selection," European journal of operational research, vol. 43, no. 3, pp.271-283, December 1989.

[142] M.Velasquez, and P. T. Hester, "An analysis of multi-criteria decision making methods," International Journal of Operations Research, vol. 10, no. 2, pp.56-66, May 2013.

[143] F.Elkarmi, and I. Mustafa. "Increasing the utilization of solar energy technologies (SET) in Jordan: Analytic Hierarchy Process," Energy Policy, vol. 21, no. 9, pp.978-984, September 1993.

[144] E. H.Forman, and S. I. Gass, "The analytic hierarchy process-an exposition," Operations research, vol. 49, no. 4, pp.469-486, 2001.

[145] T.L.Saaty, "The analytic hierarchy process: planning, priority setting, resource allocation," McGrawHill, 1980.

[146] D.F.Kocaoglu, "A participative approach to program evaluation," Engineering Management, IEEE Transactions, pp. 112-118, 1983.

[147] S.K.Lee, Y. J. Yoon, and J. W. Kim, "A study on making a long-term improvement in the national energy efficiency and GHG control plans by the AHP approach," Energy policy, vol. 35, no. 5, pp.2862-2868, May 2007.

[148] R.Ramanathan, and L. S. Ganesh, "Energy alternatives for lighting in households: an evaluation using an integrated goal programming-AHP model," Energy, vol. 20, no. 1, pp.63-72, January 1995.

[149] S.K.Lee, G. Mogi, and J. W.Kim, "The competitiveness of Korea as a developer of hydrogen energy technology: the AHP approach," Energy Policy, vol. 36, no. 4, pp.1284-1291, April 2008. 
[150] R.P.Hämäläinen, and T.O. Seppäläinen, "The analytic network process in energy policy planning," Socio-Economic Planning Sciences, vol. 20, no. 6, pp.399-405, 1986.

[151] T.Kaya, and C. Kahraman, "Multicriteria renewable energy planning using an integrated fuzzy VIKOR \& AHP methodology: The case of Istanbul," Energy, vol. 35, no. 6, pp.2517-2527, June 2010.

[152] E.Heo, J. Kim, and K.J. Boo, "Analysis of the assessment factors for renewable energy dissemination program evaluation using fuzzy AHP," Renewable and Sustainable Energy Reviews, vol. 14, no. 8, pp.2214-2220, October 2010.

[153] K.L. Poh, and B. W. Ang, "Transportation fuels and policy for Singapore: an AHP planning approach," Computers \& industrial engineering, vol. 37, no. 3, pp.507-525, November 1999.

[154] R.Ramanathan, "A note on the use of the analytic hierarchy process for environmental impact assessment," Journal of environmental management, vol. 63, no. 1, pp.27-35, September 2001.

[155] B.H. Ulutaş, "Determination of the appropriate energy policy for Turkey," Energy, vol. 30, no. 7, pp.1146-1161, June 2005.

[156] A.C. Köne, and T. Büke, "An Analytical Network Process (ANP) evaluation of alternative fuels for electricity generation in Turkey," Energy Policy, vol. 35, no. 10, pp.5220-5228, October 2007.

[157] S. Erdoğmuş, H. Aras, and E. Koç, "Evaluation of alternative fuels for residential heating in Turkey using analytic network process (ANP) with group decisionmaking," Renewable and Sustainable Energy Reviews, vol. 10, no. 3, pp.269-279, June 2006.

[158] İ.Yüksel, and M.Dagdeviren, "Using the analytic network process (ANP) in a SWOT analysis-A case study for a textile firm," Information Sciences, vol. 177, no. 16, pp.3364-3382, August 2007.

[159] P. Aragonés-Beltrán, F. Chaparro-González, J. P. Pastor-Ferrando, and F. Rodríguez-Pozo. "An ANP-based approach for the selection of photovoltaic solar power plant investment projects," Renewable and Sustainable Energy Reviews, vol. 14, no. 1, pp.249-264, January 2010. 
[160] P. Xu, and E. H. Chan, "ANP model for sustainable Building Energy Efficiency Retrofit (BEER) using Energy Performance Contracting (EPC) for hotel buildings in China," Habitat International, vol. 37, pp.104-112, January 2013.

[161] S.J. Hung, "Activity-based divergent supply chain planning for competitive advantage in the risky global environment: A DEMATEL-ANP fuzzy goal programming approach," Expert Systems with Applications, vol. 38, no. 8, pp.9053-9062, August 2011.

[162] J.Sarkis, "Evaluating environmentally conscious business practices," European journal of operational research, vol. 107, no. 1, pp.159-174, May 1998.

[163] S. Theißen, and S. Spinler, "Strategic analysis of manufacturer-supplier partnerships: An ANP model for collaborative CO 2 reduction management," European Journal of Operational Research, vol. 233, no. 2, pp.383-397, March 2014.

[164] Y.C. Shiue, and C.Y. Lin, "Applying analytic network process to evaluate the optimal recycling strategy in upstream of solar energy industry," Energy and Buildings, vol. 54, pp.266-277, November 2012.

[165] J.Mazurek, and Z. Kiszová, "Modeling dependence and feedback in ANP with fuzzy cognitive maps." In Proceedings of 30th International Conference Mathematical Methods in Economics, pp. 558-563, 2012.

[166] L.Turcksin, A. Bernardini, and C. Macharis, "A combined AHP-PROMETHEE approach for selecting the most appropriate policy scenario to stimulate a clean vehicle fleet," Procedia-Social and Behavioral Sciences, vol. 20, pp.954-965, 2011.

[167] T.Tsoutsos, M. Drandaki, N. Frantzeskaki, E. Iosifidis, and I. Kiosses, "Sustainable energy planning by using multi-criteria analysis application in the island of Crete," Energy Policy, vol. 37, no. 5, pp.1587-1600, May 2009.

[168] D.A.Haralambopoulos, and H. Polatidis, "Renewable energy projects: structuring a multi-criteria group decision-making framework," Renewable energy, vol. 28, no. 6, pp.961-973, May 2003.

[169] R.Madlener, K. Kowalski, and S. Stagl, "New ways for the integrated appraisal of national energy scenarios: the case of renewable energy use in Austria," Energy Policy, vol. 35, no. 12, pp.6060-6074, December 2007. 
[170] M.G. Goumas, V. A. Lygerou, and L. E. Papayannakis, "Computational methods for planning and evaluating geothermal energy projects," Energy policy, vol. 27, no. 3, pp.147-154, March 1999.

[171] F.Cavallaro, and L. Ciraolo, "A multicriteria approach to evaluate wind energy plants on an Italian island," Energy Policy, vol. 33, no. 2, pp.235-244, January 2005.

[172] M.Goumas, and V. Lygerou, "An extension of the PROMETHEE method for decision making in fuzzy environment: Ranking of alternative energy exploitation projects," European Journal of Operational Research, vol. 123, no. 3, pp.606613, June 2000.

[173] H. Ren, W. Gao, W. Zhou, and K.I. Nakagami, "Multi-criteria evaluation for the optimal adoption of distributed residential energy systems in Japan," Energy Policy, vol. 37, no. 12, pp.5484-5493, December 2009.

[174] F.Cavallaro, "Multi-criteria decision aid to assess concentrated solar thermal technologies," Renewable Energy, vol. 34, no. 7, pp.1678-1685, July 2009.

[175] M.J.Beynon, and P. Wells, "The lean improvement of the chemical emissions of motor vehicles based on preference ranking: A PROMETHEE uncertainty analysis," Omega, vol. 36, no. 3, pp.384-394, June 2008.

[176] A.Papadopoulos, and A. Karagiannidis, "Application of the multi-criteria analysis method Electre III for the optimisation of decentralised energy systems," Omega, vol. 36, no. 5, pp.766-776, October 2008.

[177] F.Cavallaro, "A comparative assessment of thin-film photovoltaic production processes using the ELECTRE III method," Energy Policy, vol. 38, no. 1, pp.463474, January 2010.

[178] E.Georgopoulou, D. Lalas, and L. Papagiannakis, "A multicriteria decision aid approach for energy planning problems: The case of renewable energy option," European Journal of Operational Research, vol. 103, no. 1, pp.38-54, November 1997.

[179] J.P.Huang, K. L. Poh, and B. W. Ang,"Decision analysis in energy and environmental modeling," Energy, vol. 20, no. 9, pp.843-855, September 1995. 
[180] C. Kahraman, and İ. Kaya, "A fuzzy multicriteria methodology for selection among energy alternatives," Expert Systems with Applications, vol. 37, no. 9, pp.6270-6281, September 2010.

[181] L.P.Neves, A. G. Martins, C. H. Antunes, and L. C. Dias, "A multi-criteria decision approach to sorting actions for promoting energy efficiency," Energy Policy, vol. 36, no. 7, pp.2351-2363, July 2008.

[182] Y.I.Topcu, and F. Ulengin, "Energy for the future: An integrated decision aid for the case of Turkey," Energy, vol. 29, no. 1, pp.137-154, January 2004.

[183] Y.C.Shen, G. T. Lin, K.P. Li, and B. J. Yuan, "An assessment of exploiting renewable energy sources with concerns of policy and technology," Energy Policy, vol. 38, no. 8, pp.4604-4616, August 2010.

[184] A.S.Milani, A. Shanian, and C. El-Lahham, "Using different ELECTRE methods in strategic planning in the presence of human behavioral resistance," Journal of Applied Mathematics and Decision Sciences, pp. 1-19, July 2006.

[185] D.B. Crawley, J. W. Hand, M. Kummert, and B. T. Griffith, "Contrasting the capabilities of building energy performance simulation programs," Building and environment, vol. 43, no. 4, pp.661-673, April 2008.

[186] S.Yerramalla, A. Davari, A. Feliachi, and T. Biswas, "Modeling and simulation of the dynamic behavior of a polymer electrolyte membrane fuel cell," Journal of Power Sources, vol. 124, no. 1, pp.104-113, October 2003.

[187] T. Markel, A. Brooker, T. Hendricks, V. Johnson, K. Kelly, B. Kramer, M. O'Keefe, S. Sprik, and K. Wipke, "ADVISOR: a systems analysis tool for advanced vehicle modeling," Journal of power sources, vol. 110, no. 2, pp.255266, August 2002.

[188] T.U.Daim, G. Rueda, H. Martin, and P. Gerdsri, "Forecasting emerging technologies: Use of bibliometrics and patent analysis," Technological Forecasting and Social Change, vol. 73, no. 8, pp.981-1012, October 2006.

[189] R.C. Shah, S. Roy, S. Jain, and W. Brunette, "Data mules: Modeling and analysis of a three-tier architecture for sparse sensor networks," Ad Hoc Networks, vol. 1, no. 2, pp.215-233, September 2003. 
[190] L.G. Swan, and V. I. Ugursal, "Modeling of end-use energy consumption in the residential sector: A review of modeling techniques," Renewable and sustainable energy reviews, vol. 13, no. 8, pp.1819-1835, October 2009.

[191] M.I.Kellner, R. J. Madachy, and D. M. Raffo, "Software process simulation modeling: why? what? how?," Journal of Systems and Software, vol. 46, no. 2, pp.91-105, April 1999.

[192] R.Perez, P. Ineichen, R. Seals, J. Michalsky, and R. Stewart, "Modeling daylight availability and irradiance components from direct and global irradiance," Solar energy, vol.44, no. 5, pp.271-289, 1990.

[193] K.F. Fong, V. I. Hanby, and T.T. Chow, "HVAC system optimization for energy management by evolutionary programming," Energy and Buildings, vol. 38, no. 3, pp.220-231, March 2006.

[194] Y.P. Cai, G. H. Huang, Q. G. Lin, X. H. Nie, and Q. Tan, "An optimizationmodel-based interactive decision support system for regional energy management systems planning under uncertainty," Expert Systems with Applications, vol. 36, no. 2, pp.3470-3482, March 2009.

[195] H.Yang, W. Zhou, L. Lu, and Z. Fang, "Optimal sizing method for stand-alone hybrid solar-wind system with LPSP technology by using genetic algorithm," Solar energy, vol. 82, no. 4, pp.354-367, April 2008.

[196] C.H.Li, X.J. Zhu, G.Y. Cao, S. Sui, and M.R. Hu, "Dynamic modeling and sizing optimization of stand-alone photovoltaic power systems using hybrid energy storage technology," Renewable Energy, vol. 34, no. 3, pp.815-826, March 2009.

[197] Ø.Ulleberg, "Modeling of advanced alkaline electrolyzers: a system simulation approach," International journal of hydrogen energy, vol. 28, no. 1, pp.21-33, January 2003.

[198] R.Banos, F. Manzano-Agugliaro, F. G. Montoya, C. Gil, A. Alcayde, and J. Gómez, "Optimization methods applied to renewable and sustainable energy: A review," Renewable and Sustainable Energy Reviews, vol. 15, no. 4, pp.17531766, May 2011.

[199] H.Ren, W. Gao, and Y. Ruan, "Economic optimization and sensitivity analysis of photovoltaic system in residential buildings," Renewable energy, vol. 34, no. 3, pp.883-889, March 2009. 
[200] A. Benonysson, B. Bøhm, and H. F. Ravn, "Operational optimization in a district heating system," Energy conversion and management, vol. 36, no. 5, pp.297-314, May 1995.

[201] M.Münster, and P. Meibom, "Optimization of use of waste in the future energy syste," Energy, vol. 36, no. 3, pp.1612-1622, March 2011.

[202] F. Cavallaro, "Fuzzy TOPSIS approach for assessing thermal-energy storage in concentrated solar power (CSP) systems," Applied Energy, vol. 87, no. 2, pp.496503, February 2010.

[203] M. Behzadian, S. K. Otaghsara, M. Yazdani, and J. Ignatius, "A state-of the-art survey of TOPSIS applications," Expert Systems with Applications, vol. 39, no. 17, pp.13051-13069, December 2012.

[204] I.Chamodrakas, and D. Martakos, "A utility-based fuzzy TOPSIS method for energy efficient network selection in heterogeneous wireless networks," Applied Soft Computing, vol. 12, no. 7, pp..1929-1938, June 2012.

[205] K. Sadeghzadeh, and M. B. Salehi, "Mathematical analysis of fuel cell strategic technologies development solutions in the automotive industry by the TOPSIS multi-criteria decision making method," International Journal of Hydrogen Energy, vol. 36, no. 20, pp.13272-13280, October 2011.

[206] G.Yan, Z. Ling, and Z. Dequn, "Performance evaluation of coal enterprises energy conservation and reduction of pollutant emissions base on GRD-TOPSIS," Energy Procedia, vol. 5, pp.535-539, 2011.

[207] D. Choudhary, and R. Shankar, "An STEEP-fuzzy AHP-TOPSIS framework for evaluation and selection of thermal power plant location: A case study from India," Energy, vol. 42, no. 1, pp.510-521, June 2012.

[208] E.Wang, "Benchmarking whole-building energy performance with multi-criteria technique for order preference by similarity to ideal solution using a selective objective-weighting approach," Applied Energy, vol. 146, pp.92-103, May 2015.

[209] E.Bas, "The integrated framework for analysis of electricity supply chain using an integrated SWOT-fuzzy TOPSIS methodology combined with AHP: The case of Turkey," International Journal of Electrical Power \& Energy Systems, vol. 44, no. 1, pp.897-907, January 2013. 
[210] S.Haehnlein, P. Bayer, and P. Blum, "International legal status of the use of shallow geothermal energy," Renewable and Sustainable Energy Reviews, vol. 14, no. 9, pp.2611-2625, December 2010.

[211] T.U.Daim, G. Kayakutlu, and K. Cowan,"Developing Oregon's renewable energy portfolio using fuzzy goal programming model," Computers \& Industrial Engineering, vol. 59, no. 4, pp.786-793, November 2010.

[212] Energyhomes.Org, "Leadership in Energy and Environmental Design", Centennial, CO, 2008.

[213] C.M. Kraan, "Drivers and barriers to deep geothermal energy in the Netherlands: what are the implications of government policy?", M.Sc, University of Edinburgh, School of Geosciences, August 2013.

[214] "Geothermal Basics - Power Plant Costs", Geo-energy.org, 2016. [Online]. Available: http://geo-energy.org/geo_basics_plant_cost.aspx. [Accessed: 29May- 2016].

[215] L. Rybach, "Geothermal energy: sustainability and the environment," Geothermics, vol. 32, no. 4, pp.463-470, August 2003.

[216] "Northwest Energy Efficiency Task Force", Nwcouncil.org, 2016. [Online]. Available: http://www.nwcouncil.org/energy/neet/home/. [Accessed: 29- May2016].

[217] State of Oregon, Employment Department, "Population Growth Rate Increases in Oregon for Third Straight Year", W. Burchard, August 2015.

[218] V.P. Shah, D. C. Debella, and R. J. Ries, "Life cycle assessment of residential heating and cooling systems in four regions in the United States," Energy and buildings, vol. 40, no. 4, pp.503-513, 2008.

[219] G.R.Newsham, and B. G. Bowker, "The effect of utility time-varying pricing and load control strategies on residential summer peak electricity use: a review," Energy Policy, vol. 38, no. 7, pp.3289-3296, July 2010.

[220] R.Saidur, "A review on electrical motors energy use and energy savings," Renewable and Sustainable Energy Reviews, vol. 14, no. 3, pp.877-898, April 2010.

[221] E.Regnier, "Oil and energy price volatility," Energy Economics, vol. 29, no. 3, pp.405-427, May 2007. 
[222] K.Kaygusuz, and A. Kaygusuz, "Geothermal energy in Turkey: the sustainable future," Renewable and Sustainable Energy Reviews, vol. 8, no. 6, pp.545-563, December 2004.

[223] Geothermal Energy Association, "Annual U.S. \& Global Geothermal Power Production Report", Geo-Energy.Org, 2015.

[224] T.Daim, D. Yates, Y. Peng, and B. Jimenez, "Technology assessment for clean energy technologies: the case of the Pacific Northwest," Technology in Society, vol. 31, no. 3, pp.232-243, August 2009.

[225] P.Gerdsri, and D.Kocaoglu, "A systematic approach to developing national technology policy and strategy for emerging technologies: A case study of nanotechnology for Thailand's agriculture industry," In Management of Engineering \& Technology, 2009. PICMET 2009. Portland International Conference, pp. 447-461, 2009.

[226] S.K.Lee, G. Mogi, and J. W. Kim, "The competitiveness of Korea as a developer of hydrogen energy technology: the AHP approach," Energy Policy, vol. 36, no. 4, pp.1284-1291, April 2008.

[227] R.P.Hämäläinen, and R. Karjalainen, "Decision support for risk analysis in energy policy," European Journal of Operational Research, vol. 56, no. 2, pp.172-183, January 1992.

[228] P.Gerdsri, and D. F. Kocaoglu, "HDM for developing national emerging technology strategy and policy supporting sustainable economy: a case study of nanotechnology for Thailand's agriculture," In Management of Engineering \& Technology, 2008. PICMET 2008. Portland International Conference, pp. 344350, 2008.

[229] F.Elkarmi, and I.Mustafa, "Increasing the utilization of solar energy technologies (SET) in Jordan: Analytic Hierarchy Process," Energy Policy, vol. 21, no. 9, pp.978-984, September 1993.

[230] S.K.Lee, Y. J. Yoon, and J. W. Kim, "A study on making a long-term improvement in the national energy efficiency and GHG control plans by the AHP approach," Energy policy, vol. 35, no. 5, pp.2862-2868, May 2007.

[231] "Geothermal Technologies Program", D. K. Garman, U.S. Department of Energy, Energy Efficiency and Renewable Energy. 
[232] I.B.Fridleifsson, "Geothermal energy for the benefit of the people," Renewable and sustainable energy reviews, vol. 5, no. 3, pp.299-312, September 2001.

[233] C.Tourkolias, and S. Mirasgedis, "Quantification and monetization of employment benefits associated with renewable energy technologies in Greece," Renewable and Sustainable Energy Reviews, vol. 15, no. 6, pp.2876-2886, August 2011.

[234] Z. Agioutantis, and A. Bekas, "The potential of district heating using geothermal energy. A case study, Greece," Geothermics, vol. 29, no. 1, pp.51-64, February 2000 .

[235] A. I.Chatzimouratidis, and P. A. Pilavachi, "Multicriteria evaluation of power plants impact on the living standard using the analytic hierarchy process," Energy Policy, vol. 36, no. 3, pp.1074-1089, March 2008.

[236] U.Lehr, J. Nitsch, M. Kratzat, C. Lutz, and D. Edler, "Renewable energy and employment in Germany," Energy policy, vol. 36, no. 1, pp.108-117, January 2008 .

[237] "Geothermal Rules Encourage AlternativeEnergy Development on Federal Lands", Doi.gov, 2016. [Online]. Available:

https://www.doi.gov/sites/doi.gov/files/archive/news/archive/06_News_Releases/ 060721a.htm. [Accessed: 01- Jun- 2016].

[238] "Geothermal Energy", U.S. Department of interior, Bureau of land management.

[239] "Geothermal Energy Why it matters to Oregon", Oregon Department of Energy, Salem, December 2014.

[240] A. Evans, V. Strezov, and T. J. Evans, "Assessment of sustainability indicators for renewable energy technologies," Renewable and sustainable energy reviews, vol. 13, no. 5, pp.1082-1088, June 2009.

[241] H.Hondo, "Life cycle GHG emission analysis of power generation systems: Japanese case," Energy, vol. 30, no. 11, pp.2042-2056, August 2005.

[242] N.L.Panwar, S. C. Kaushik, and S. Kothari, "Role of renewable energy sources in environmental protection: a review," Renewable and Sustainable Energy Reviews, vol. 15, no. 3, pp.1513-1524, April 2011. 
[243] K.Kaygusuz, "Energy and environmental issues relating to greenhouse gas emissions for sustainable development in Turkey," Renewable and Sustainable Energy Reviews, vol. 13, no. 1, pp.253-270, January 2009.

[244] P.Bayer, D. Saner, S. Bolay, L. Rybach, and P. Blum, "Greenhouse gas emission savings of ground source heat pump systems in Europe: A review," Renewable and Sustainable Energy Reviews, vol. 16, no. 2, pp.1256-1267, February 2012.

[245] M.Z.Jacobson, and M.A. Delucchi, "Providing all global energy with wind, water, and solar power, Part I: Technologies, energy resources, quantities and areas of infrastructure, and materials," Energy Policy, vol. 39, no. 3, pp.11541169, March 2011.

[246] S.A.Abbasi, and N. Abbasi, "The likely adverse environmental impacts of renewable energy sources," Applied Energy, vol. 65, no. 1, pp.121-144, April 2000 .

[247] B.J.De Vries, D. P. Van Vuuren, and M. M. Hoogwijk, "Renewable energy sources: Their global potential for the first-half of the 21st century at a global level: An integrated approach," Energy policy, vol. 35, no. 4, pp.2590-2610, April 2007.

[248] H.Mahmoudi, N. Spahis, M. F. Goosen, N. Ghaffour, N. Drouiche, and A. Ouagued, "Application of geothermal energy for heating and fresh water production in a brackish water greenhouse desalination unit: A case study from Algeria," Renewable and Sustainable Energy Reviews, vol. 14, no. 1, pp.512-517, January 2010.

[249] M.C.Fehler, "Stress control of seismicity patterns observed during hydraulic fracturing experiments at the Fenton Hill Hot Dry Rock geothermal energy site, New Mexico," International Journal of Rock Mechanics and Mining Sciences \& Geomechanics Abstracts, vol. 26, no. 3, pp. 211-219, 1989.

[250] R.J.Pine, and A. S. Batchelor, "Downward migration of shearing in jointed rock during hydraulic injections," International Journal of Rock Mechanics and Mining Sciences \& Geomechanics Abstracts, vol. 21, no. 5, pp. 249-263, October 1984.

[251] K.F.Evans, A. Zappone, T. Kraft, N. Deichmann, and F. Moia, "A survey of the induced seismic responses to fluid injection in geothermal and $\mathrm{CO} 2$ reservoirs in Europe," Geothermics, vol. 41, pp.30-54, January 2012. 
[252] E.L.Majer, and J. E. Peterson, "The impact of injection on seismicity at The Geysers, California Geothermal Field," International Journal of Rock Mechanics and Mining Sciences, vol. 44, no. 8, pp.1079-1090, December 2007.

[253] J.Charléty, N. Cuenot, L. Dorbath, C. Dorbath, H. Haessler, and M. Frogneux, "Large earthquakes during hydraulic stimulations at the geothermal site of Soultzsous-Forêts," International Journal of Rock Mechanics and Mining Sciences, vol. 44, no. 8, pp.1091-1105, December 2007.

[254] J.Chang, D. Y. Leung, C. Z. Wu, and Z. H. Yuan, "A review on the energy production, consumption, and prospect of renewable energy in China," Renewable and Sustainable Energy Reviews, vol. 7, no. 5, pp.453-468, October 2003.

[255] M.Asif, and T. Muneer, "Energy supply, its demand and security issues for developed and emerging economies," Renewable and Sustainable Energy Reviews, vol. 11, no. 7, pp.1388-1413, September 2007.

[256] A. K. Akella, R. P. Saini, and M. P. Sharma, "Social, economical and environmental impacts of renewable energy systems," Renewable Energy, vol. 34, no. 2, pp.390-396, February 2009.

[257] A. M. Omer, "Energy, environment and sustainable development," Renewable and sustainable energy reviews, vol. 12, no. 9, pp.2265-2300, December 2008.

[258] S.H.Shuit, K.T. Tan, K. T. Lee, and A. H. Kamaruddin, "Oil palm biomass as a sustainable energy source: a Malaysian case study," Energy, vol. 34, no. 9, pp.1225-1235, September 2009.

[259] S.Bilgen, S. Keleş, A. Kaygusuz, A. Sarı, and K. Kaygusuz, "Global warming and renewable energy sources for sustainable development: a case study in Turkey," Renewable and Sustainable Energy Reviews, vol. 12, no. 2, pp.372-396, February 2008.

[260] I.B.Fridleifsson,"Status of geothermal energy amongst the world's energy sources," Geothermics, vol. 32, no. 4, pp.379-388, August 2003.

[261] F.Evrendilek, and C. Ertekin, "Assessing the potential of renewable energy sources in Turkey," Renewable Energy, vol. 28, no. 15, pp.2303-2315, December 2003. 
[262] A.Kumar, K.Kumar, N. Kaushik, S. Sharma, and S. Mishra, "Renewable energy in India: current status and future potentials," Renewable and Sustainable Energy Reviews, vol. 14, no. 8, pp.2434-2442, October 2010.

[263] P.A.Østergaard, and H.Lund, "A renewable energy system in Frederikshavn using low-temperature geothermal energy for district heating," Applied Energy, vol. 88, no. 2, pp.479-487, February 2011.

[264] B.Rezaie, and M. A. Rosen, "District heating and cooling: Review of technology and potential enhancements," Applied Energy, vol. 93, pp.2-10, May 2012.

[265] C.R.Chamorro, M. E. Mondéjar, R. Ramos, J. J. Segovia, M. C. Martín, and M. A. Villamañán, "World geothermal power production status: Energy, environmental and economic study of high enthalpy technologies," Energy, vol. 42, no. 1, pp.1018, June 2012.

[266] J. W. Lund, D. H. Freeston, and T. L. Boyd, "Direct utilization of geothermal energy 2010 worldwide review," Geothermics, vol. 40, no. 3, pp.159-180, September 2011.

[267] M.Ball, and M. Wietschel, "The future of hydrogen-opportunities and challenges," International Journal of Hydrogen Energy, vol. 34, no. 2, pp.615627, January 2009.

[268] P.Crompton, and Y. Wu, "Energy consumption in China: past trends and future directions," Energy economics, vol. 27, no. 1, pp.195-208, January 2005.

[269] J.P.Dorian, H. T. Franssen, and D. R. Simbeck, "Global challenges in energy," Energy Policy, vol. 34, no. 15, pp.1984-1991, October 2006.

[270] A.Franco, and A. R. Diaz, "The future challenges for "clean coal technologies": joining efficiency increase and pollutant emission control," Energy, vol. 34, no. 3, pp.348-354, March 2009.

[271] T.H.Oh, S. Y. Pang, and S. C. Chua, "Energy policy and alternative energy in Malaysia: issues and challenges for sustainable growth," Renewable and Sustainable Energy Reviews, vol. 14, no. 4, pp.1241-1252, May 2010.

[272] G.J.Stiegel, and M. Ramezan, "Hydrogen from coal gasification: an economical pathway to a sustainable energy future," International Journal of Coal Geology, vol. 65, no. 3, pp.173-190, January 2006. 
[273] I.Dincer,"Renewable energy and sustainable development: a crucial review," Renewable and Sustainable Energy Reviews, vol. 4, no. 2, p.157-175, June 2000.

[274] M.Momirlan, and T. N. Veziroglu, "The properties of hydrogen as fuel tomorrow in sustainable energy system for a cleaner planet," International journal of hydrogen energy, vol. 30, no. 7, pp.795-802, July 2005.

[275] J.W.Lund, D. H. Freeston, and T. L. Boyd, "Direct application of geothermal energy: 2005 worldwide review," Geothermics, vol. 34, no. 6, pp.691-727, December 2005.

[276] G.Chiodini, and R. Cioni, "Gas geobarometry for hydrothermal systems and its application to some Italian geothermal areas," Applied geochemistry, vol. 4, no. 5, pp.465-472, September 1989.

[277] A.Hepbasli, and O. Akdemir, "Energy and exergy analysis of a ground source (geothermal) heat pump system," Energy Conversion and Management, vol. 45, no. 5, pp.737-753, March 2004.

[278] W.Casas, and G. Schmitz, "Experiences with a gas driven, desiccant assisted air conditioning system with geothermal energy for an office building," Energy and buildings, vol. 37, no. 5, pp.493-501, May 2005.

[279] B.Sanner, C. Karytsas, D. Mendrinos, and L. Rybach, "Current status of ground source heat pumps and underground thermal energy storage in Europe," Geothermics 32, no. 4, pp.579-588, August 2003.

[280] W.G.Cai, Y. Wu, Y. Zhong, and H. Ren, "China building energy consumption: situation, challenges and corresponding measures, "Energy policy, vol. 37, no. 6, pp.2054-2059, June 2009.

[281] S.Hähnlein, P. Bayer, G. Ferguson, and P. Blum, "Sustainability and policy for the thermal use of shallow geothermal energy," Energy Policy, vol. 59, pp.914925, August 2013.

[282] I.Dincer, "Renewable energy and sustainable development: a crucial review." Renewable and Sustainable Energy Reviews, vol.4, no.2, pp.157-175, June 2000.

[283] A.Allen, D. Milenic, and P. Sikora, "Shallow gravel aquifers and the urban "heat island'effect: a source of low enthalpy geothermal energy," Geothermics, vol. 32, no.4, pp.569-578, 2003. 
[284] A.B.Stambouli, Z. Khiat, S. Flazi, and Y. Kitamura, "A review on the renewable energy development in Algeria: current perspective, energy scenario and sustainability issues," Renewable and sustainable energy reviews, vol.16, no.7, pp.4445-4460, September 2012.

[285] M. F. Akorede, H. Hizam, and E. Pouresmaeil, "Distributed energy resources and benefits to the environment," Renewable and Sustainable Energy Reviews, vol. 14, no. 2, pp.724-734, February 2010.

[286] R. G. Bloomquist, "Geothermal space heating," Geothermics, vol.32, no. 4, pp.513-526, 2003.

[287] L.Y.Shen, and V. W. Tam, "Implementation of environmental management in the Hong Kong construction industry," International Journal of Project Management, vol. 20, no. 7, pp.535-543, October 2002.

[288] T.Tsoutsos, N. Frantzeskaki, and V. Gekas, "Environmental impacts from the solar energy technologies," Energy Policy, vol. 33, no. 3, pp.289-296, February 2005 .

[289] S.Payraudeau, and H. M. van der Werf, "Environmental impact assessment for a farming region: a review of methods," Agriculture, Ecosystems \& Environment, volume. 107, no. 1, pp.1-19, May 2005.

[290] D.Krajnc, and P. Glavič, "A model for integrated assessment of sustainable development," Resources, Conservation and Recycling, vol. 43, no. 2, pp.189208, January 2005.

[291] A.Menegaki, "Valuation for renewable energy: a comparative review," Renewable and Sustainable Energy Reviews, vol. 12, no. 9, pp.2422-2437, December 2008.

[292] C.M.Tam, V. W. Tam, and W. S. Tsui, "Green construction assessment for environmental management in the construction industry of Hong Kong," International Journal of Project Management, vol. 22, no. 7, pp.563-571, October 2004.

[293] U.Berardi, "Stakeholders' influence on the adoption of energy-saving technologies in Italian homes," Energy Policy. Vol. 60, pp.520-530, September 2013. 
[294] A.Gilchrist, and E. N. Allouche, "Quantification of social costs associated with construction projects: state-of-the-art review," Tunnelling and underground space technology, vol. 20, no. 1, pp.89-104, January 2005.

[295] N.Christie, K. Smyth, R. Barnes, and M. Elliott, "Co-location of activities and designations: A means of solving or creating problems in marine spatial planning?," Marine Policy, volume. 43, pp.254-261, January 2014.

[296] Geo-energy.org, 'Geothermal Basics - Basics', 2015. [Online]. Available: http://geo-energy.org/Basics.aspx. [Accessed: 25- Jun- 2015].

[297] B.Huang, Z. Ouyang, H. Zheng, H. Zhang, and X. Wang, "Construction of an eco-island: a case study of Chongming Island, China," Ocean \& Coastal Management, vol. 51, no. 8, pp.575-588, 2008.

[298] E.Barbier, "Geothermal energy technology and current status: an overview" Renewable and Sustainable Energy Reviews, volume. 6, no. 1, pp.3-65, 2002.

[299] Energyalmanac.ca.gov, 'Types of Geothermal Power Plants', 2015. [Online]. Available: http://energyalmanac.ca.gov/renewables/geothermal/types.html. [Accessed: 25- Jun- 2015].

[300] M.Yari, "Exergetic analysis of various types of geothermal power plants," Renewable Energy, vol. 35, no. 1, pp.112-121, January 2010.

[301] Q.Shanben, L. I. Fangxun, and L. I. Nianru, "Turbogenerator units operating on duo-flash cycle in the Yangbajain geothermal power plant, Tibet, China," In Energy Conversion Engineering Conference, 1989. IECEC-89., Proceedings of the 24th Intersociety, pp. 2151-2154, 1989.

[302] D.L.Gallup, "Combination flash-bottoming cycle geothermal power generation: a case history," In Energy Conversion Engineering Conference, 1996. IECEC 96., Proceedings of the 31st Intersociety, vol. 3, pp. 1622-1627, 1996.

[303] S.Jalilinasrabady, R. Itoi, P. Valdimarsson, G. Saevarsdottir, and H. Fujii, "Flash cycle optimization of Sabalan geothermal power plant employing exergy concept," Geothermics, vol. 43, pp.75-82, July 2012.

[304] C.Luo, L. Huang, Y. Gong, and W. Ma, "Thermodynamic comparison of different types of geothermal power plant systems and case studies in China," Renewable energy, vol. 48, pp. 155-160, December 2012. 
[305] Geothermal.marin.org, 'Introduction to Geothermal Energy - Power Plant Geysers 2', 2015. [Online]. Available: http://geothermal.marin.org/geopresentation/sld053.htm. [Accessed: 25- Jun2015].

[306] C.R.Chamorro, M.E. Mondéjar, R. Ramos, J. J. Segovia, M. C. Martín, and M. A. Villamañán, "World geothermal power production status: Energy, environmental and economic study of high enthalpy technologies," Energy, vol. 42, no. 1, pp.1018, June 2012.

[307] Onlinenevada.org, 'Steamboat Springs Geothermal Field |ONE', 2015. [Online]. Available: http://www.onlinenevada.org/articles/steamboat-springs-geothermalfield. [Accessed: 25- Jun- 2015].

[308] C.J.Bliem, and G. L. Mines, Advanced binary geothermal power plants: Limits of performance, EG and G Idaho, January 1991.

[309] J.W.Lund, and R. Klein, "Prawn Park-Taupo, New Zealand," Geo-Heat Center Quarterly Bulletin, vol. 16, no. 4, pp.27-29, 1995.

[310] A.H.Truesdell, and D. E. White, "Production of superheated steam from vapordominated geothermal reservoirs," Geothermics, vol. 2, no. 3, pp.154-173, September 1973.

[311] M.Kanoglu, "Exergy analysis of a dual-level binary geothermal power plant" Geothermics, vol. 31, no. 6, pp.709-724, December 2002.

[312] M.Kanoğlu, and Y. A. Çengel, "Economic evaluation of geothermal power generation, heating, and cooling," Energy, vol. 24, no. 6, pp.501-509, June 1999.

[313] B.Toni, 'Geothermal Demonstration Project", 2011.

[314] Oit.edu, 'Geo-Heat Center', 2015. [Online]. Available: http://www.oit.edu/orec/geo-heat-center. [Accessed: 25- Jun- 2015].

[315] " Renewable Energy in Oregon," American Council On Renewable Energy (ACORE), September 2014.

[316] Geothermal Exchange Organization, 'Geothermal Exchange Organization Geothermal Heat Pumps', 2015. [Online]. Available: https://www.geoexchange.org/. [Accessed: 25- Jun- 2015]. 
[317] Energy.gov, 'Direct Use of Geothermal Energy | Department of Energy', 2015. [Online]. Available: http://energy.gov/eere/geothermal/direct-use-geothermalenergy. [Accessed: 25- Jun- 2015].

[318] G.W.Huttrer, "The status of world geothermal power generation 1995-2000," Geothermics, vol. 30, no. 1, pp.1-27, February 2001.

[319] S.Hurter, and R. Schellschmidt, "Atlas of geothermal resources in Europe," Geothermics, vol. 32, no. 4, pp.779-787, August 2003.

[320] R.Cataldi, F. Mongelli, P. Squarci, L. Taffi, G. Zito, and C. Calore, "Geothermal ranking of Italian territory," Geothermics, vol. 24, no. 1, pp.115-129, February 1995.

[321] R.G.Bloomquist, "Geothermal space heating," Geothermics, vol. 32, no. 4, pp.513-526, August 2003.

[322] J.W.Lund,"The USA geothermal country update," Geothermics, vol. 32, no. 4, pp.409-418, August 2003.

[323] Energy.gov, 'Geothermal Heat Pumps', 2015. [Online]. Available: http://energy.gov/energysaver/articles/geothermal-heat-pumps. [Accessed: 25Jun- 2015].

[324] Oregon.gov, 'Geothermal Energy Ground-Source Heat Pumps', 2015. [Online]. Available: http://www.oregon.gov/energy/renew/geothermal/pages/gshp.aspx. [Accessed: 25- Jun- 2015].

[325] J.Current, S. Ratick, and C. ReVelle, "Dynamic facility location when the total number of facilities is uncertain: A decision analysis approach," European Journal of Operational Research, vol. 110, no. 3, pp.597-609, November 1998.

[326] C.Okoli, and S. D. Pawlowski, "The Delphi method as a research tool: an example, design considerations and applications," Information \& management, vol. 42, no. 1, pp.15-29, December 2004.

[327] N. Sheikh, T. Daim, and D. F. Kocaoglu, "Use of multiple perspectives and decision modeling for PV technology assessment," In Technology Management in the Energy Smart World (PICMET 2011), pp. 1-21, 2011.

[328] D.J.Nutt, L. A. King, and L. D. Phillips, "Drug harms in the UK: a multicriteria decision analysis," The Lancet, vol. 376, no. 9752, pp.1558-1565, November 2010. 
[329] S.Y.Kim, J. H. Karlawish, and E. D. Caine, "Current state of research on decision-making competence of cognitively impaired elderly persons," The American journal of geriatric psychiatry, vol. 10, no. 2, pp.151-165, March 2002.

[330] M.J.Liberatore, and R. L. Nydick, "The analytic hierarchy process in medical and health care decision making: A literature review," European Journal of Operational Research, vol. 189, no. 1, pp.194-207, August 2008.

[331] J.Shanteau, "Psychological characteristics and strategies of expert decision makers," Acta Psychologica, vol. 68, no. 1-3, pp.203-215, September 1988.

[332] T.U.Daim, "'Technology evaluation and acquisition strategies and their implications in the US electronics manufacturing industry.' Portland State University, 1998.

[333] A.J.M.R.H.Fink, American Journal of Public Health, vol. 74, pp. 979-983, 1984.

[334] D.J.Weiss, and J. Shanteau, "Empirical assessment of expertise," Human Factors: The Journal of the Human Factors and Ergonomics Society, vol. 45, no. 1, pp.104-116, 2003.

[335] J.W.Ra, "Analysis of expert judgments in hierarchical decision process," University of Pittsburgh, (1988).

[336] D.F. Kocaoglu,"A participative approach to program evaluation," Engineering Management, IEEE Transactions on, pp.112-118, 1983. 


\begin{abstract}
APPENDICES
Appendix A- Instruments for the invitation of experts
\end{abstract}

Appendix A1- The invitation of experts for participation in my M.S Thesis research

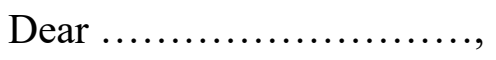

My name is Ahmed Alshareef and I am a M.S student from the Engineering and Technology Management department at Portland State University. I am writing to invite you to participate in my research study called Technology Assessment Model of Developing Geothermal Energy Resources for Supporting Electrical System: The case for Oregon. This research study is being conducted in partial fulfillment of the requirements for a Master degree in Engineering and Technology Management at Portland State University.

You're eligible to be in this study because you are an expert from either academia or industry and will have enough experience to provide feedback on the criteria in the model I am researching.

Your participation in my research is important to developing a framework, measurement system, and metric for reaching the best benefit of geothermal energy resources. My research looks at the problem from different perspectives and dimensions with respect to utility objectives and goals.

The proposed research model that I developed requires participation of experts who have knowledge and opinions in the topic area of Geothermal Energy Resources. Participation in the online survey/evaluation will take approximately 30 minutes to complete. This will help to further construct the model and establish a weight for selecting elements that require further development.

If you decide to participate in this study, you will make judgments on different criteria, using paired comparison between two elements, deciding which element is more important between the two. Remember, this is completely voluntary. You can choose to be in the study or not.

If you'd like to participate or have any questions about the study, please email or contact me at aalsha2@pdx.edu or contact me (503) 867-9279. 
If you have any concerns or problems about participating in this study or your rights as a research subject, please contact the PSU Office of Research Integrity, 1600 SW 4th

Ave., Market Center Building Ste. 620, Portland, OR, 97201; phone (503) 725-2227 or 1 (877) $480-4400$

Thank you very much.

Sincerely,

Ahmed Alshareef

M.S Student

Department of Engineering and Technology Management

Portland State University 


\section{Appendix A2-Informed Consent Form}

\section{Informed Consent Template: Online Survey Consent}

You are invited to participate in a research study, entitled "Technology Assessment Model of Developing Geothermal Energy Resources for Supporting Electrical System.” The study is being conducted by Ahmed Alshareef, graduate student from Engineering and Technology Management Department at Portland State University. The study is under the supervision my advisor, Tugrul Daim.

The purpose of this research study is to examine which technologies are important for developing Geothermal Energy. Your participation in the study will contribute to a better understanding of the different criteria with more knowledge to know which criteria in the model require developing and making more research on it to cover it from different prospective]. This project is being conducted in partial fulfillment of the requirements for a M.S degree under the supervision of Dr. Tugrul U. Daim. You are invited as a potential participant due to your expertise in the area of energy sector due to your qualification and professional experience. You are free to contact the investigator at the above address and phone number to discuss the study. You must be at least 18 years old to participate.

If you agree to participate, the evaluation will take approximately 30 minutes of your time and you will complete an activity about [Developing Geothermal Energy Resources for Supporting Electrical System.

There are no known risks to participate and all the information will be kept in my laptop and I will destroy the information after one year of graduation. There are no costs for participating, nor will you personally benefit from participating. Your name and email address will be collected during the data collection phase for tracking purposes only. Identifying information will be stripped from the final dataset.

Your participation in this study is voluntary. You may decline to answer any question and you have the right to withdraw from participation at any time. Withdrawal will not affect your relationship with Portland State University in any way. If you do not want to participate either simply stop participating or close the browser window. I may send study reminders about participation in the study. If you do not want to receive any more reminders, you may email me at aalsha2@pdx.edu.

If you have any questions about the study or need to update your email address contact me, Ahmed Alshareef, at 503-867-9279 or send an email to aalsha2@ pdx.edu. You may also contact my advisor, Tugrul Daim at ji2td@pdx.edu.

If you have questions about your rights or are dissatisfied at any time with any part of this study, you can contact the Human Subjects Research Review Committee at hsrrc@pdx.edu, Market Center Building, $6^{\text {th }}$ floor, 1600 SW $4^{\text {th }}$ Ave., Portland OR 97201. 
If you agree to participate, click on the following link [HTTP://LINK TO STUDY URL] Thank you.

Please print a copy of this document for your records. 


\section{Appendix A3- Content Web Survey}

Dear ........,

Thank you so much for accepting the invitation to complete the survey for my thesis research (Technology Assessment Model of Developing Geothermal Energy Resource for Supporting Electrical System). I have attached the link of the survey, the instructions and the explanation of the research. You can see the details of each node in the model of the survey by pointing your cursor over the node. Each node had been explained in the instruction document.

Thank you very much.

Sincerely,

Ahmed Alshareef

M.S Student

Department of Engineering and Technology Management

Portland State University 


\section{Appendix A4-Content Questionnaire Survey}
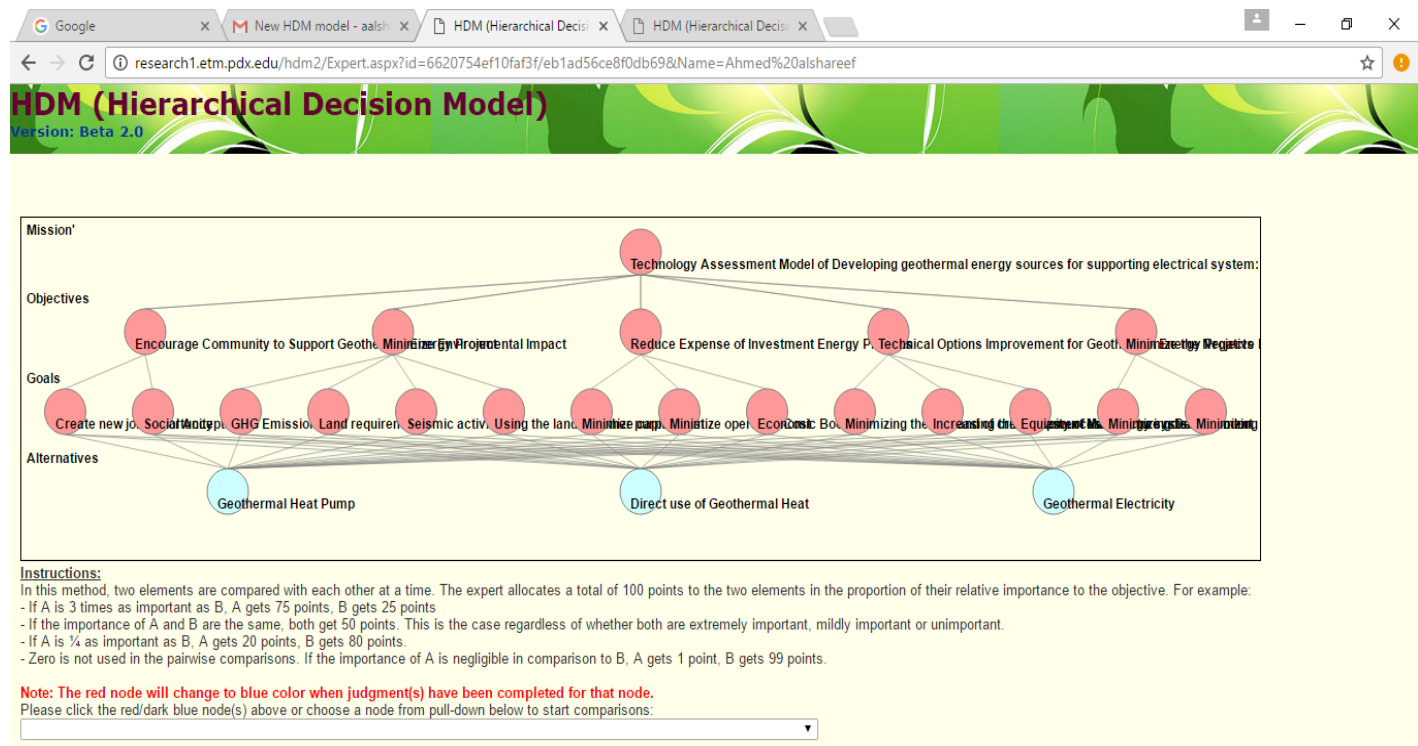

\# OAskmeanything

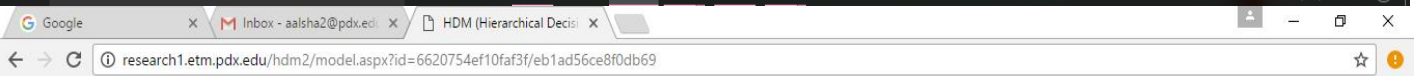
HbM (Hierarchical Decision Model)

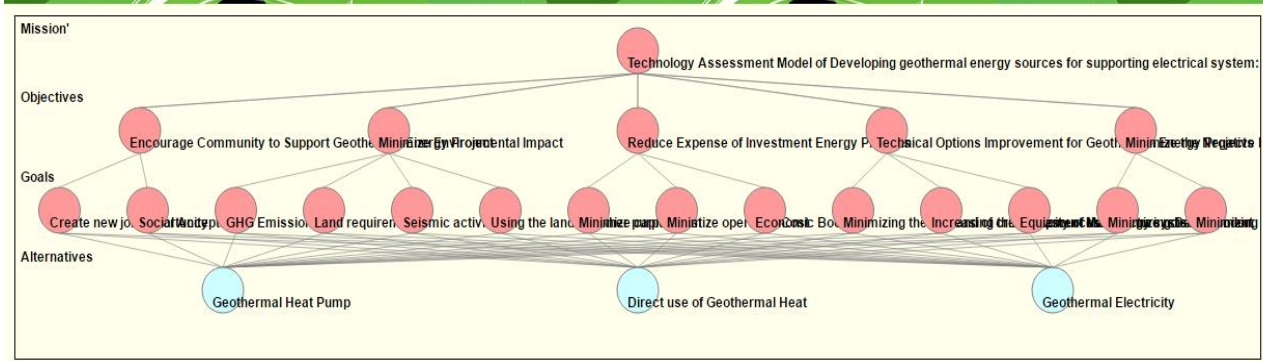

URL for expert (The Whole Model): http-//research1.etm.pdx.edu/HDM2/expert.aspx?id=6620754ef10faf3f//blad56ce8fodb69 (send email) Click the red node to get the URL for that node only for expert (The Sub-model)

Back Delete This Model

\# $\mathrm{O}$ Ask me anything

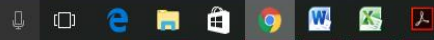




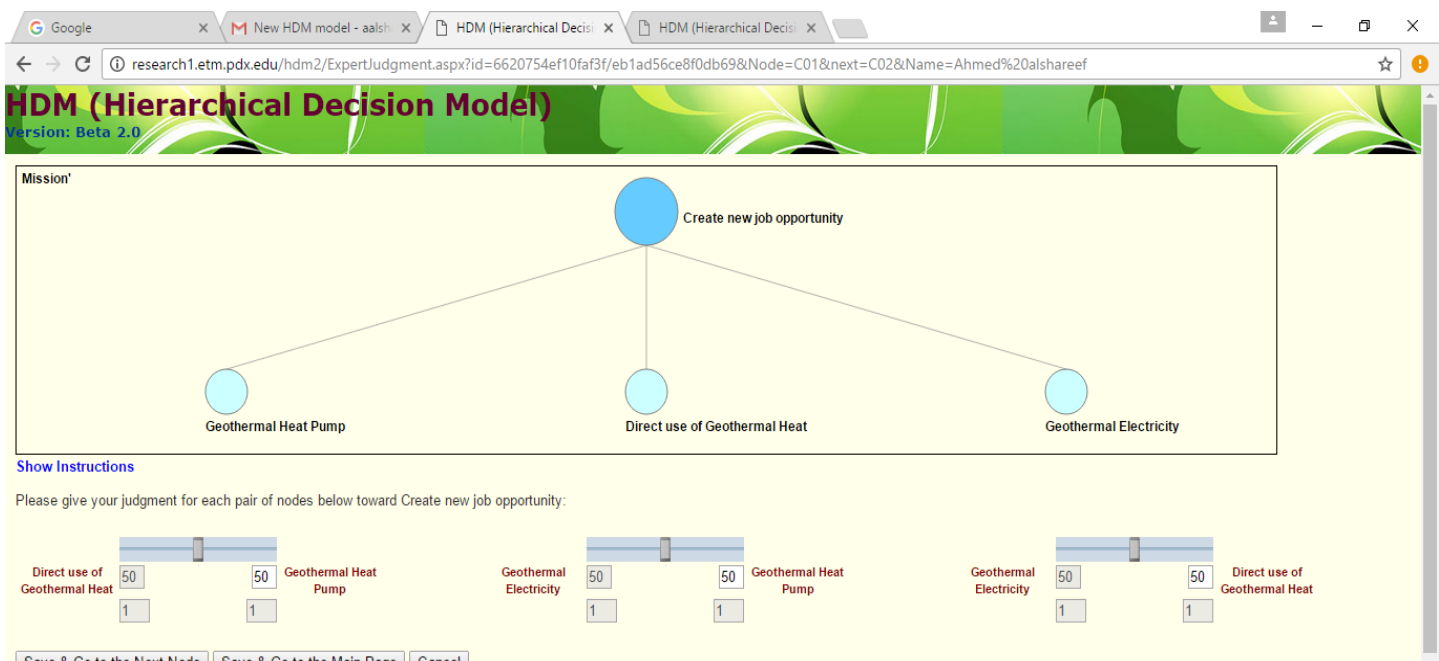

\begin{tabular}{|l|l|l|}
\hline Save \& Go to the Next Node Save \& Go to the Main Page Cancel \\
\hline
\end{tabular}

\# OAskmeanything

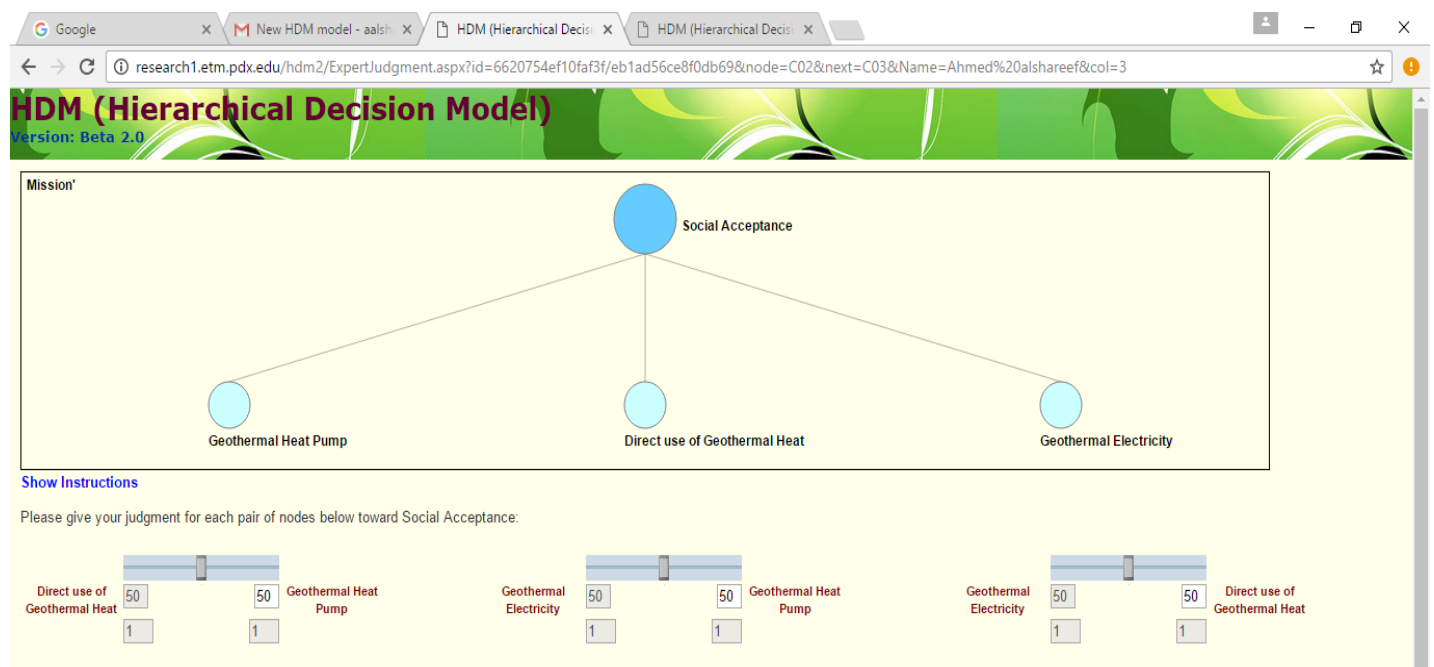

Save \& Go to the Next Node Save \& Go to the Main Page Cancel

H. OAsk me anything 


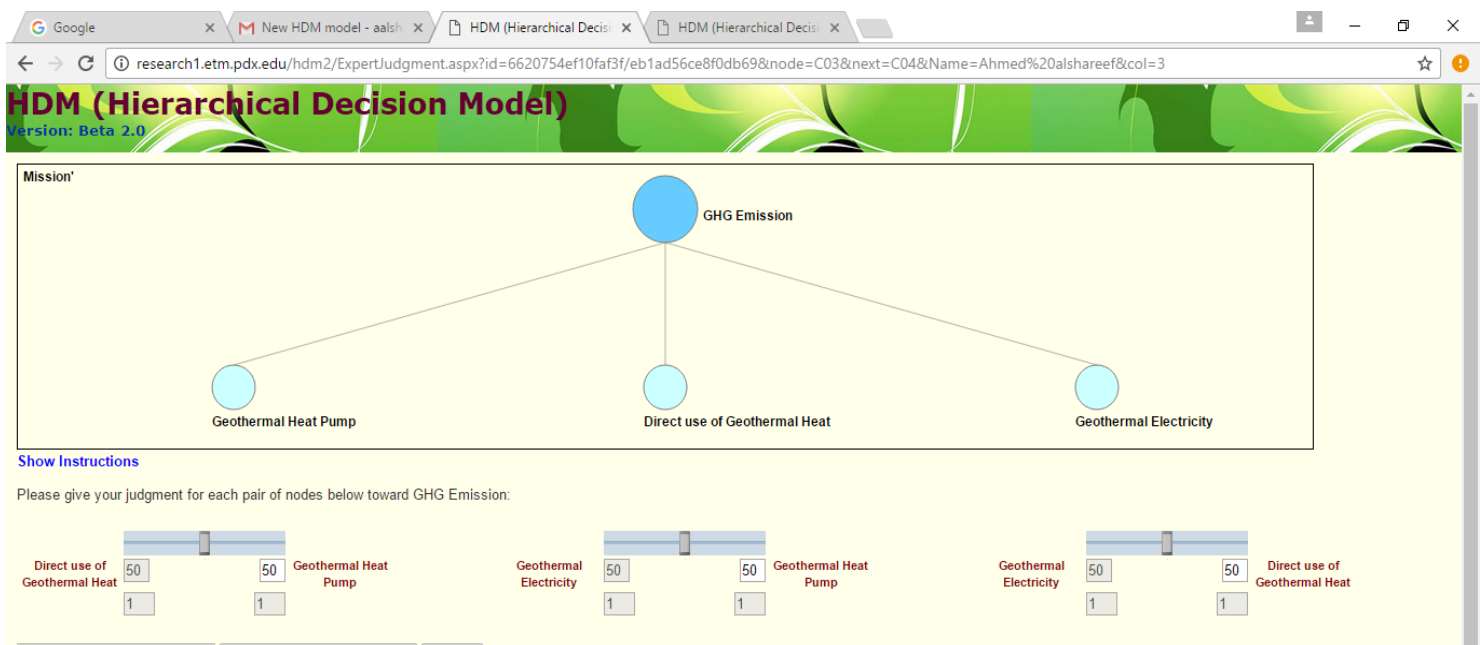

\begin{tabular}{|l|l|}
\hline Save \& Go to the Next Node Save \& Go to the Main Page Cancel \\
\hline
\end{tabular}

* OAskme anything

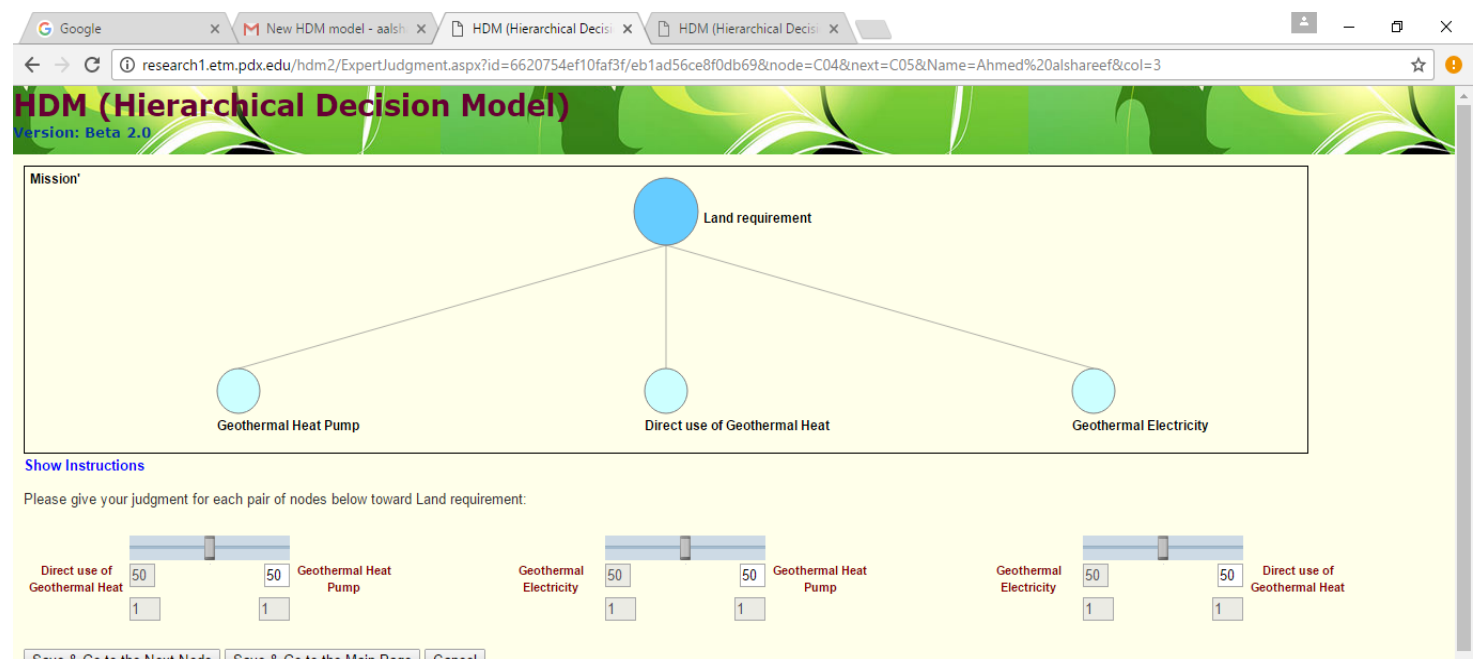

Save \& Go to the Next Node Save \& Go to the Main Page Cancel

* $O$ Ask me anything 


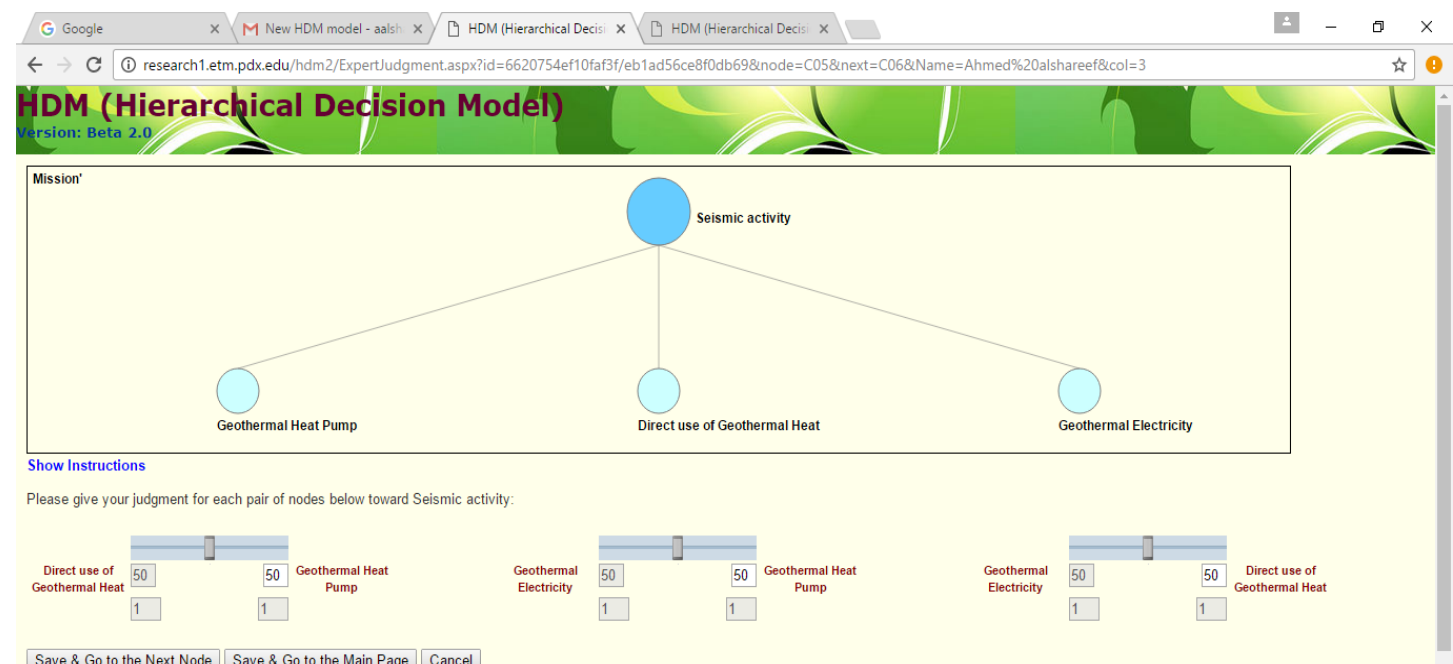

Save \& Go to the Next Node Save \& Go to the Main Page Cancel

\section{\# OAskmeanything}

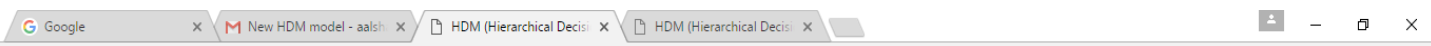

$\leftarrow \rightarrow$ C (1) research1.etm.pdx.edu/hdm2/Expertudgment.aspx?id=6620754ef10faf3//eb1ad56ce8fodb69\&node=C068next=C07\&/Name=Ahmed\%20alshareef\&col=3
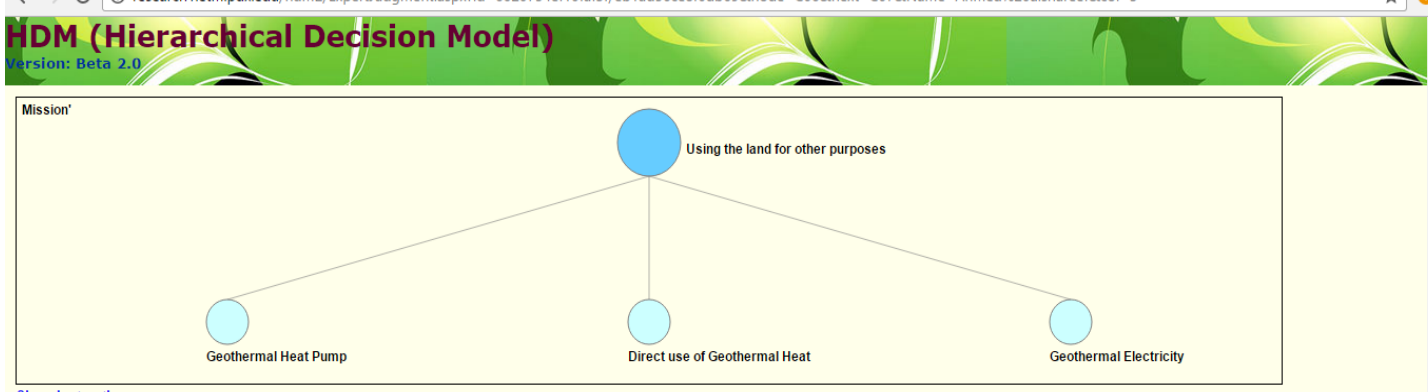

Show Instructions

Please give your judgment for each pair of nodes below toward Using the land for other purposes:

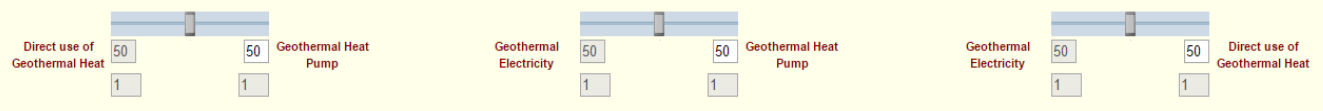

Save \& Go to the Next Node Save \& Go to the Main Page Cancel 


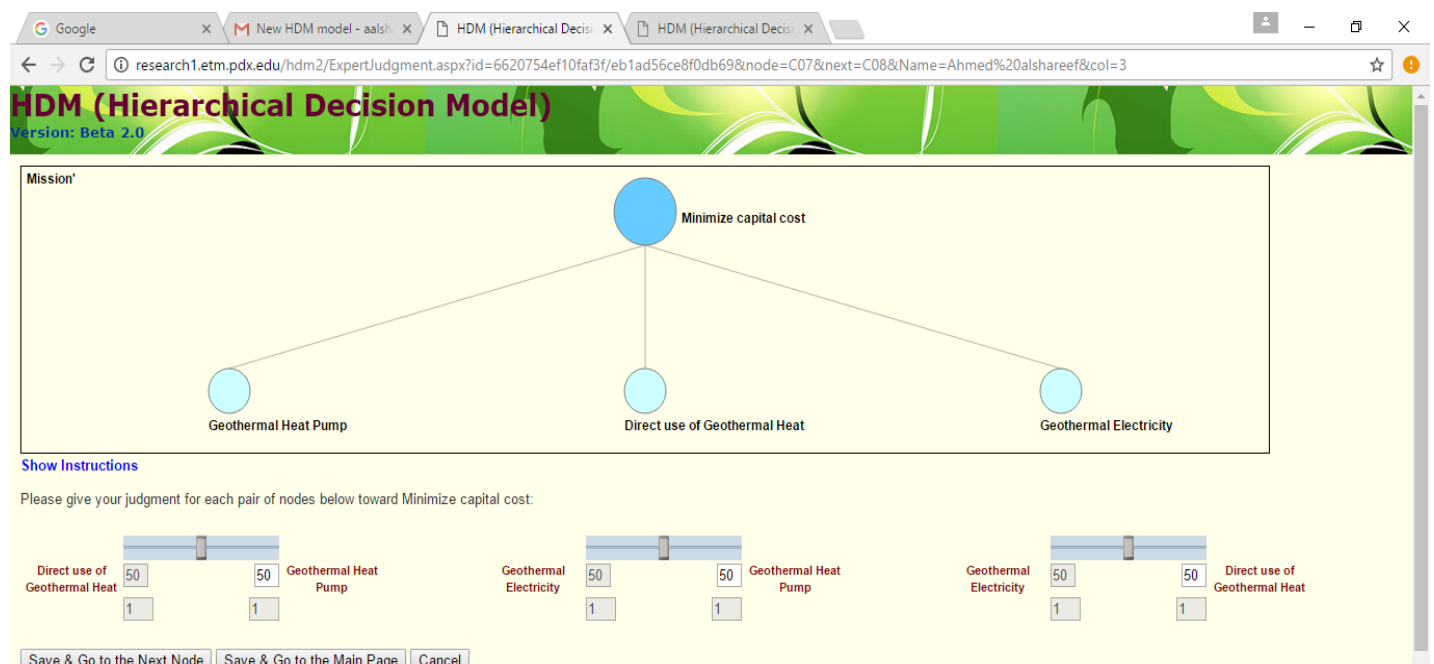

Save \& Go to the Next Node Save \& Go to the Main Page Cancel

\section{* OAskmeanyting}

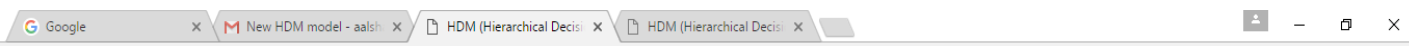

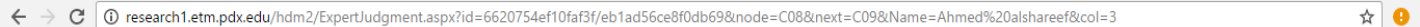
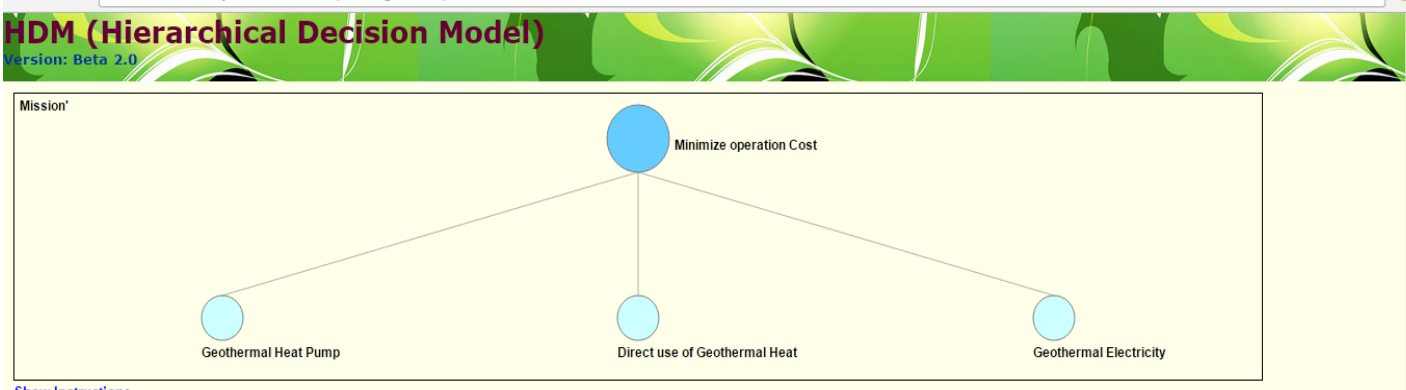

Show Instruction

Please give your judgment for each pair of nodes below toward Minimize operation cost
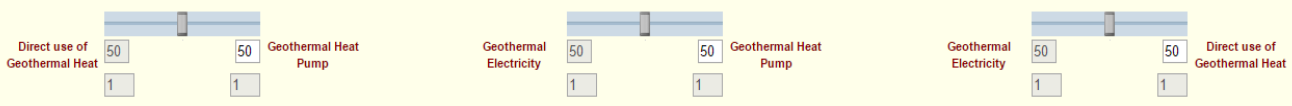

Save \& Go to the Next Node Save \& Go to the Main Page Cancel 


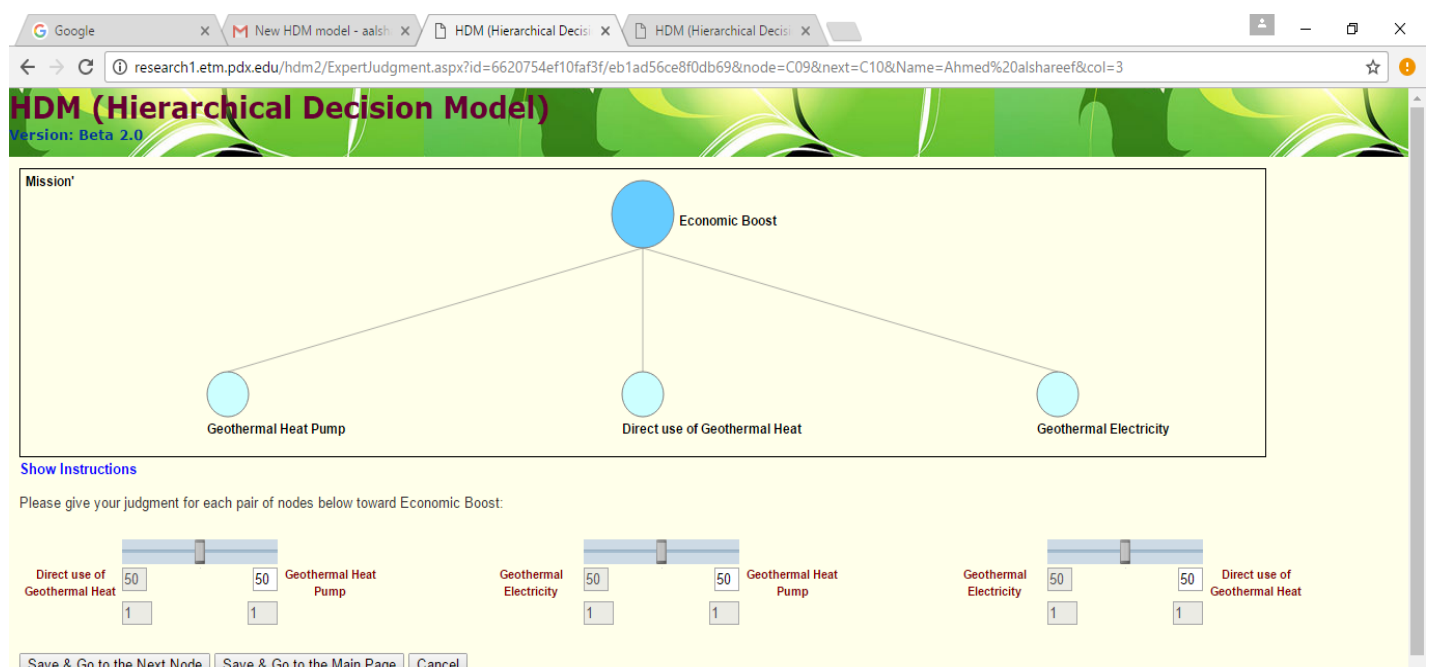

Save \& Go to the Next Node Save \& Go to the Main Page Cancel

\# $O$ Ask me anything

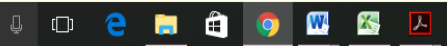

(3)八

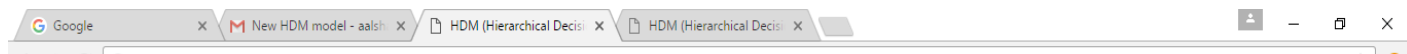

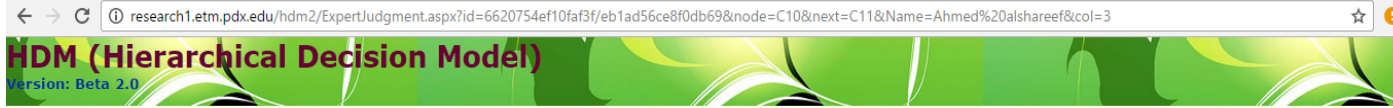

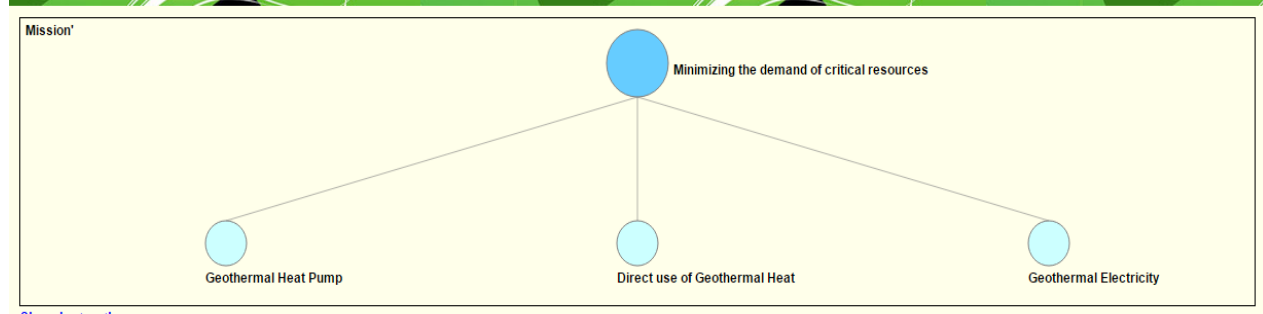

Show Instructions

Please give your judgment for each pair of nodes below toward Minimizing the demand of critical resources:

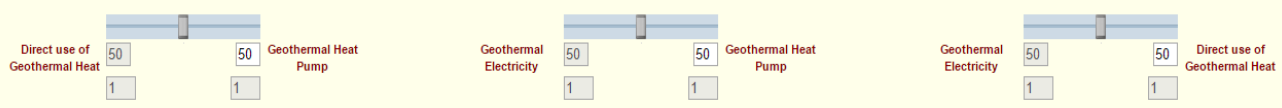

Save \& Go to the Next Node Save \& Go to the Main Page Cancel

* O Ask me anything

미

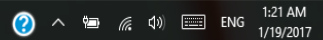




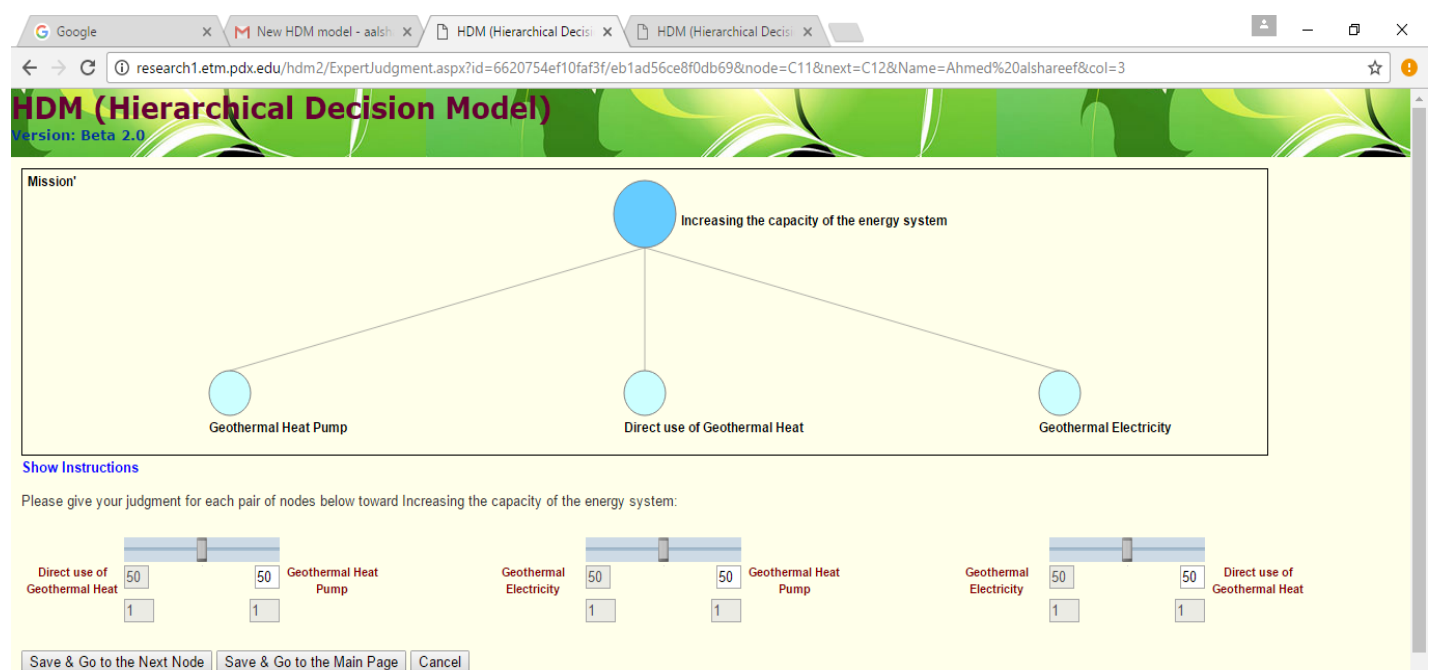

\section{* OAskmeanyting}

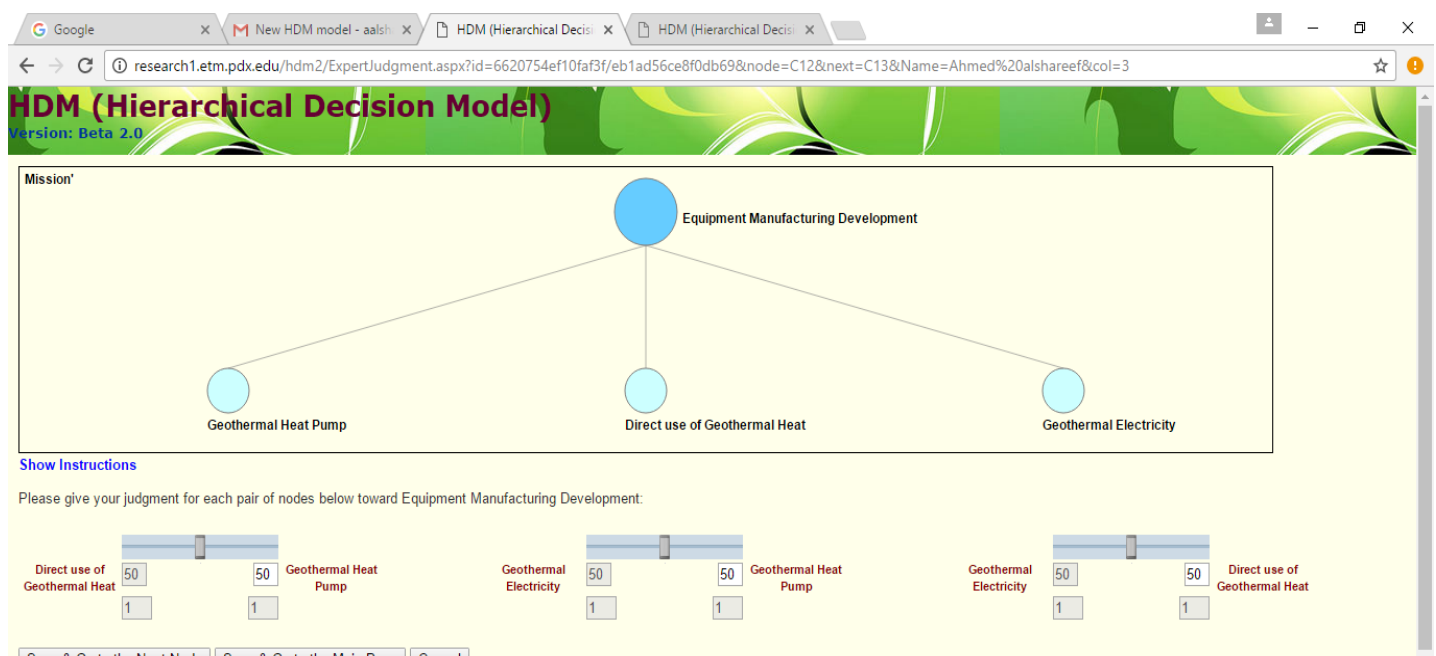

\begin{tabular}{|l|l|}
\hline Save \& Go to the Next Node Save \& Go to the Main Page Cancel \\
\hline
\end{tabular} 


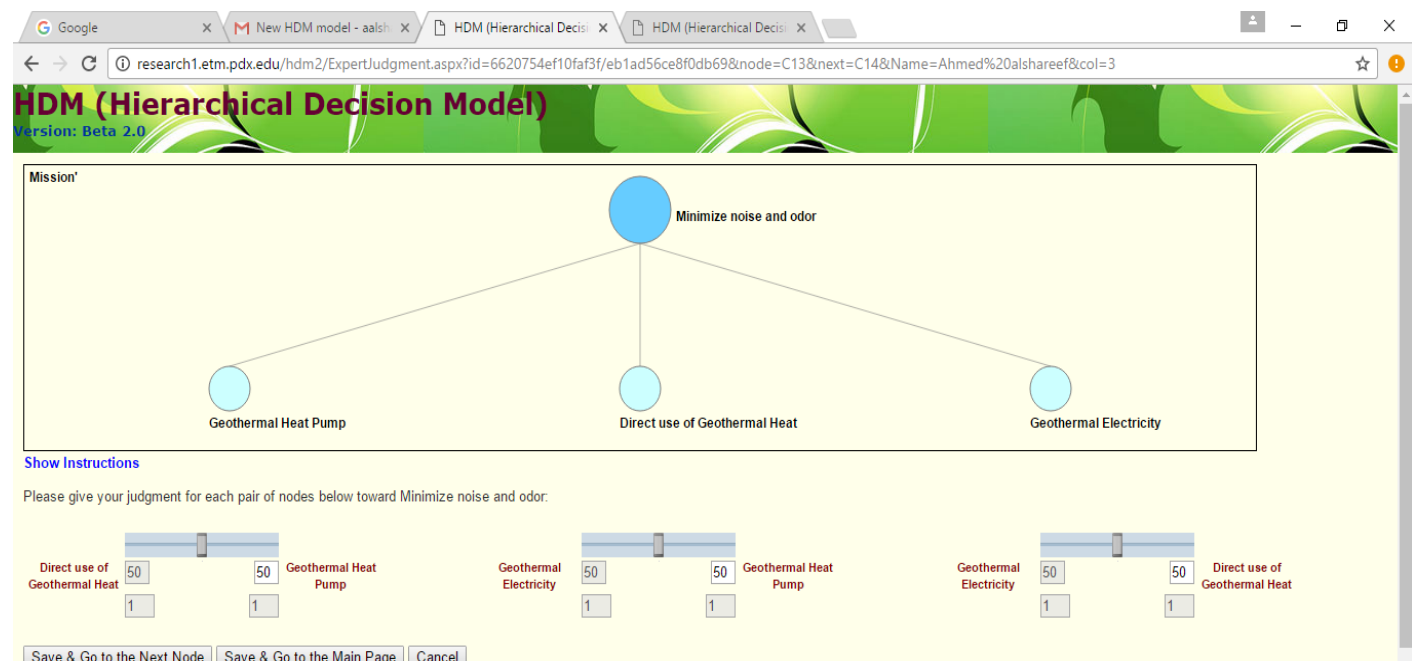

Save \& Go to the Next Node Save \& Go to the Main Page Cancel

\section{* OAskmeanything}

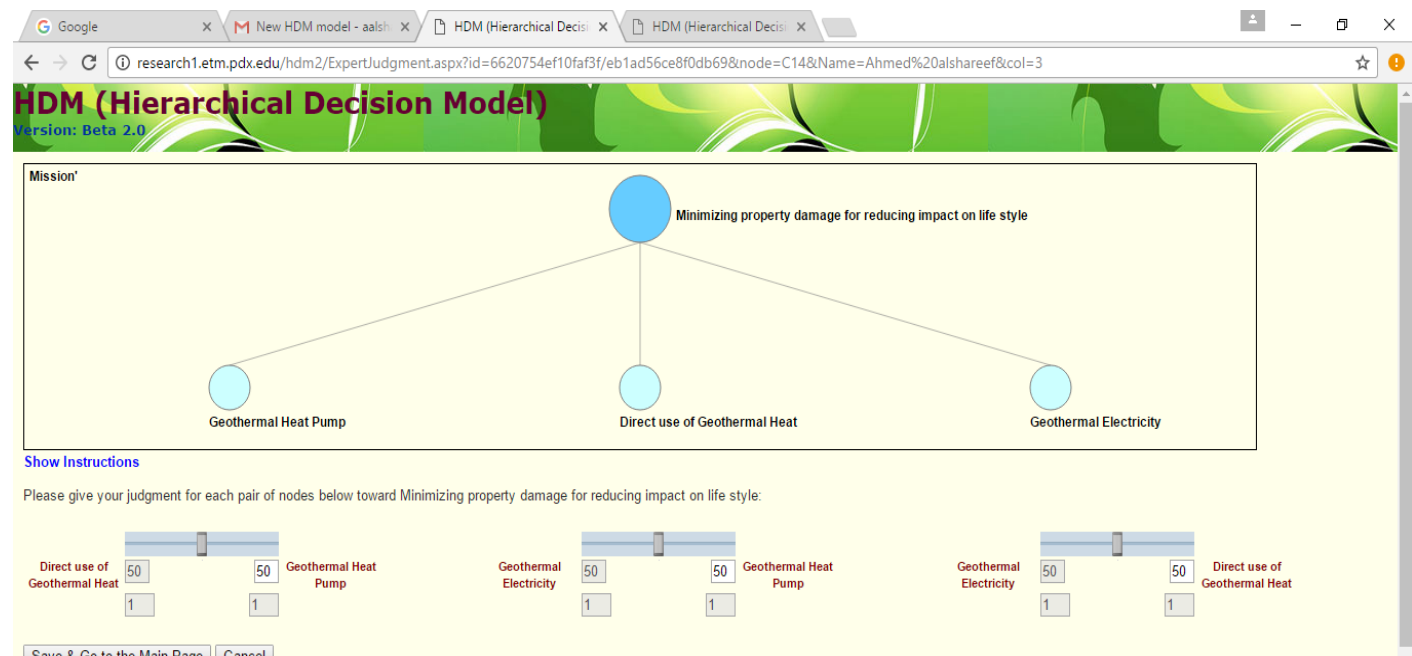

Save \& Go to the Main Page Cancel 


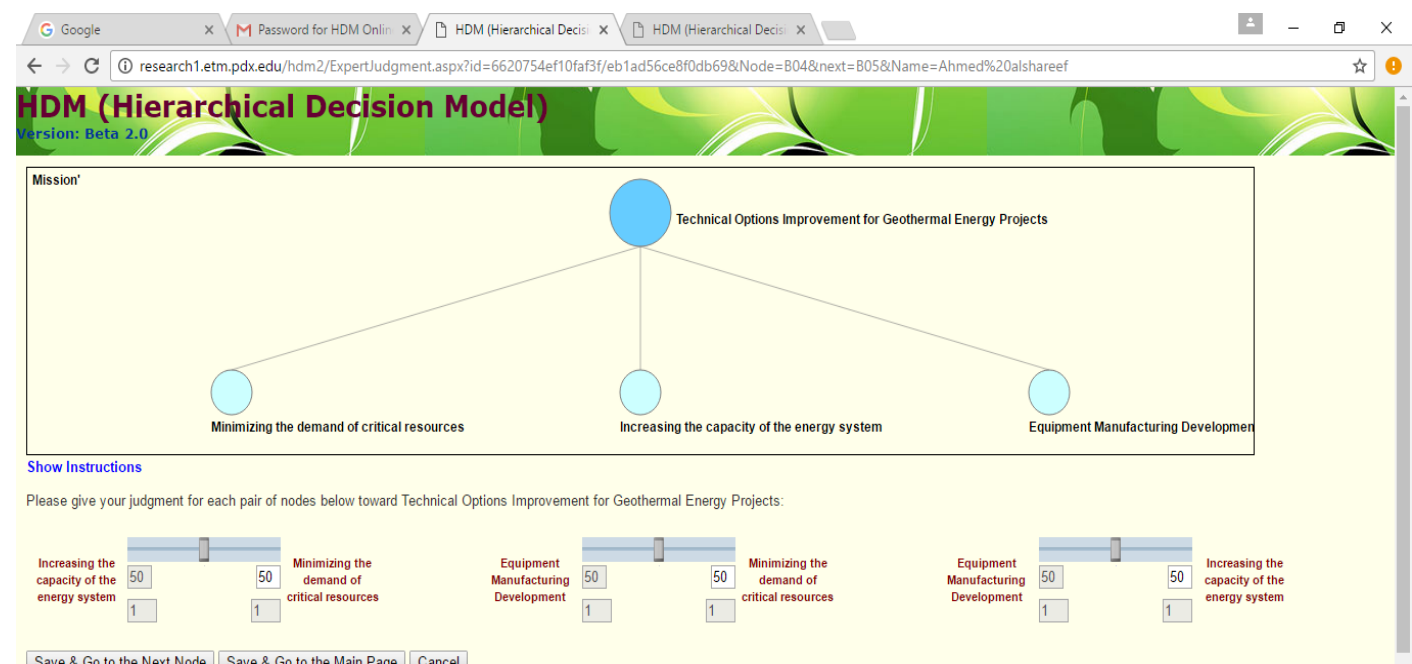

Save \& Go to the Next Node Save \& Go to the Main Page Cancel

\section{\# OAskmeanything}

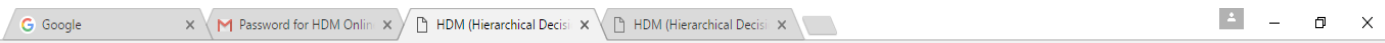

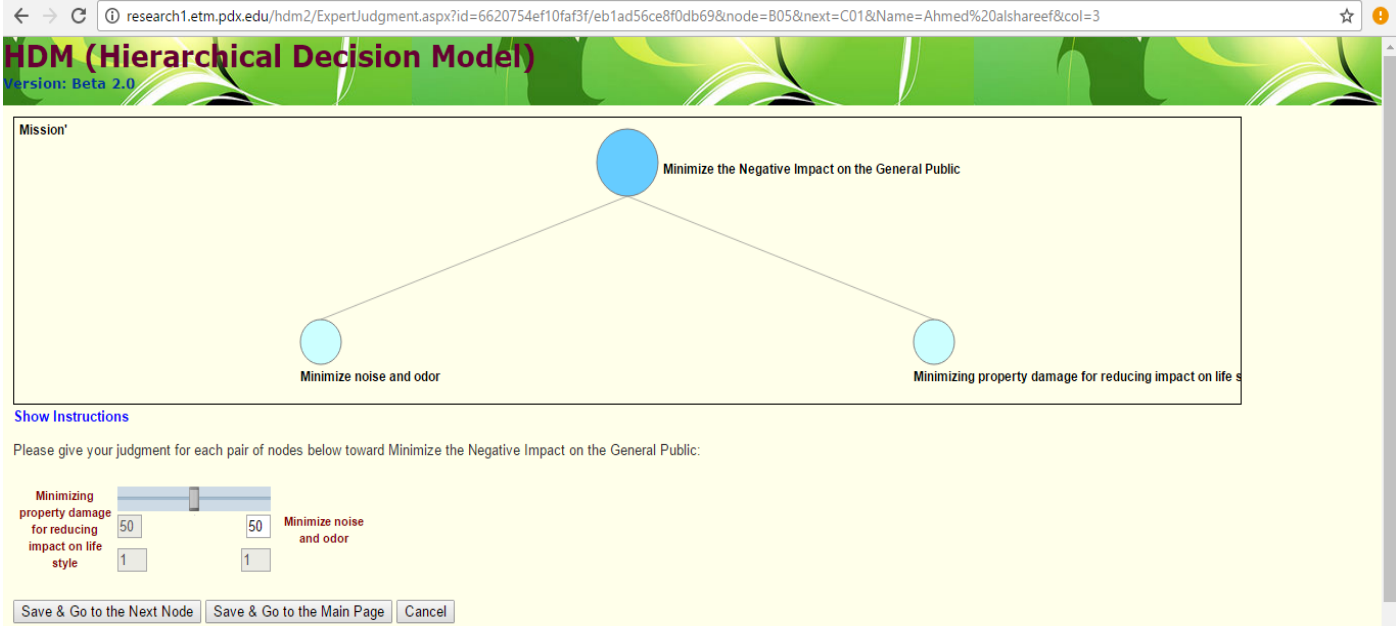

\# $\mathrm{O}$ Ask me anything 


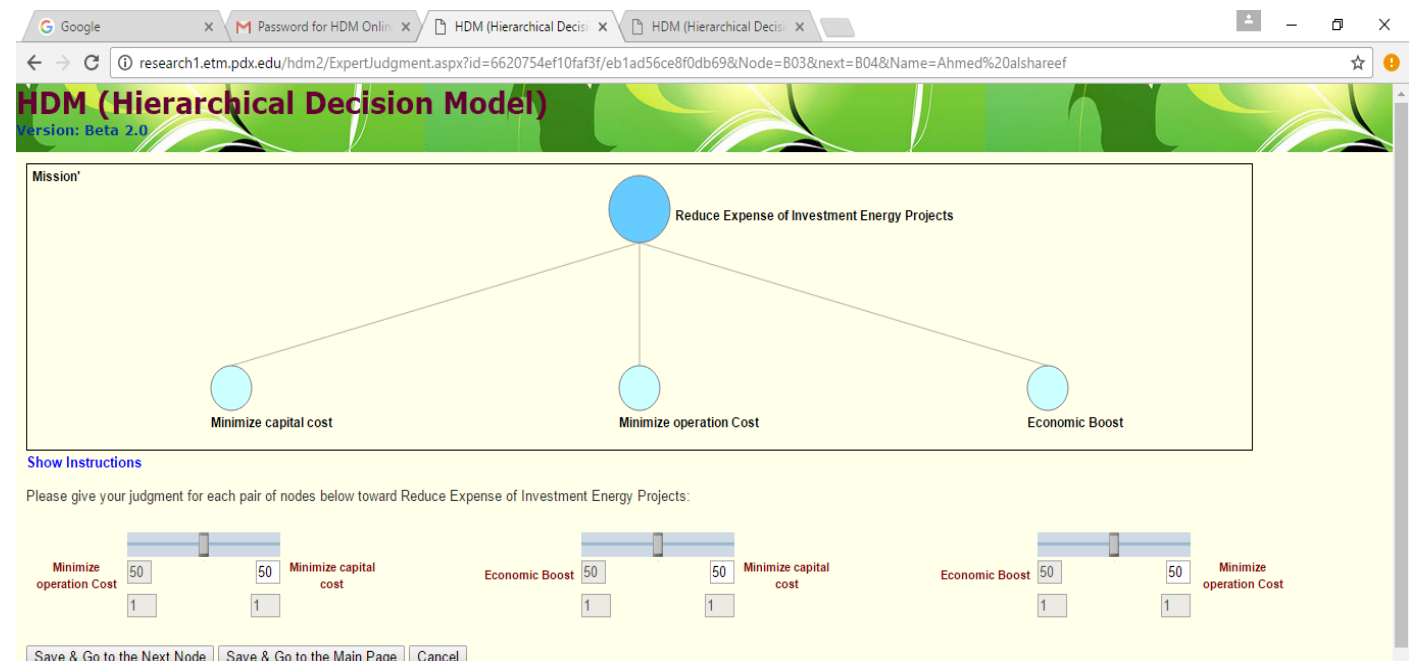

\begin{tabular}{|l|l|}
\hline Save \& Go to the Next Node Save \& Go to the Main Page Cancel \\
\hline
\end{tabular}

\section{* OAskmeanything}

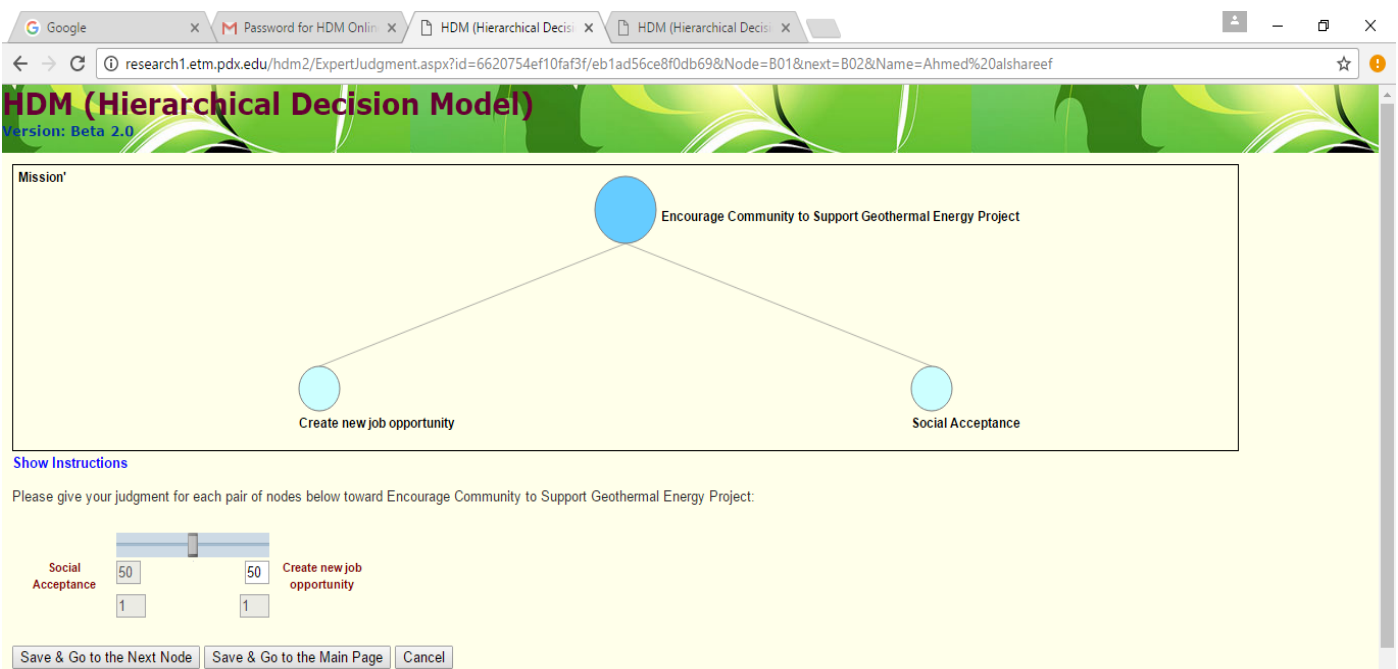

* $O$ Ask me anything 


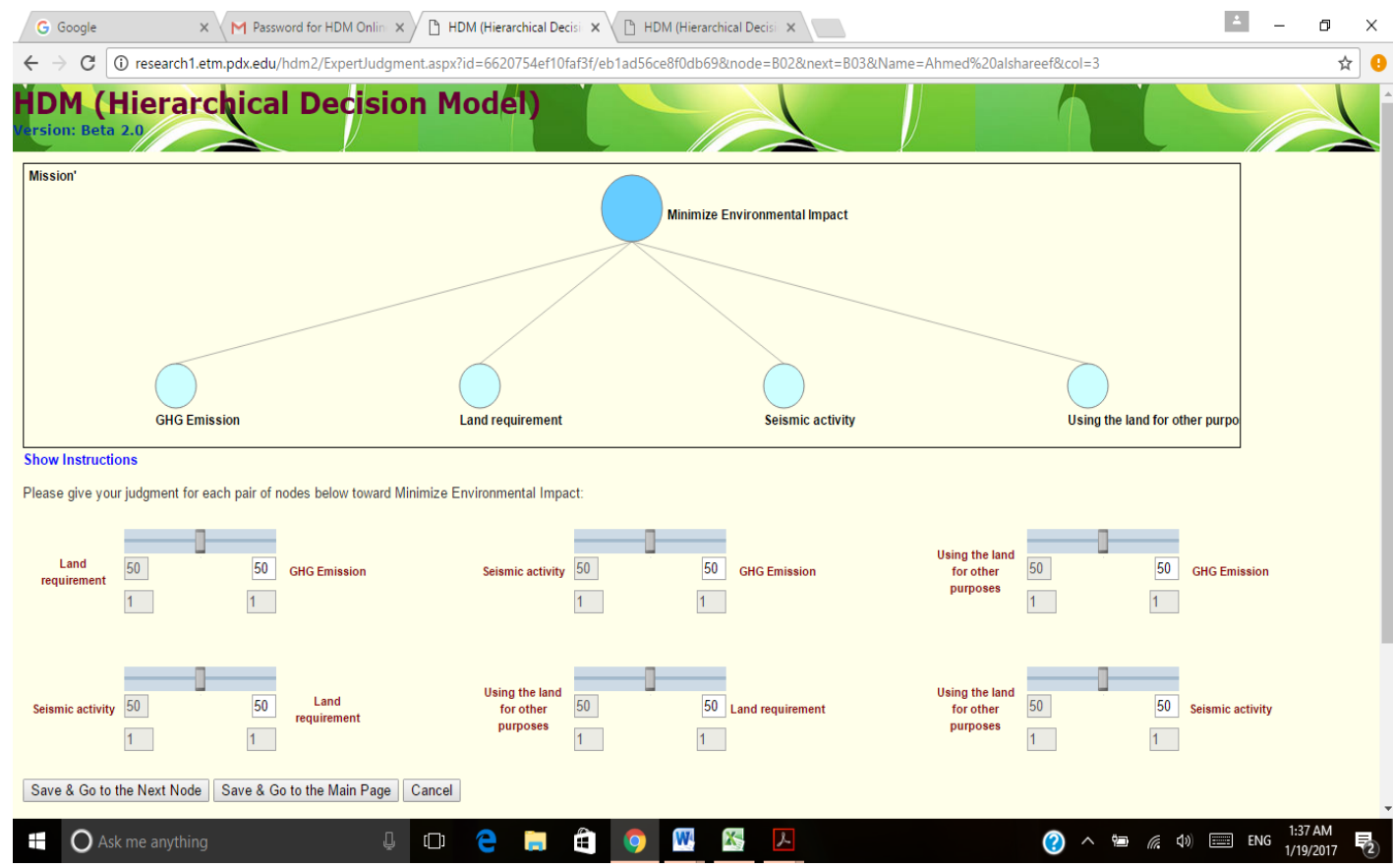




\section{Appendix A5-Content instructions and explanation of nodes}

The figure below shows the proposed research model. This figure will be used to establish the weight of each element and analyze the model:

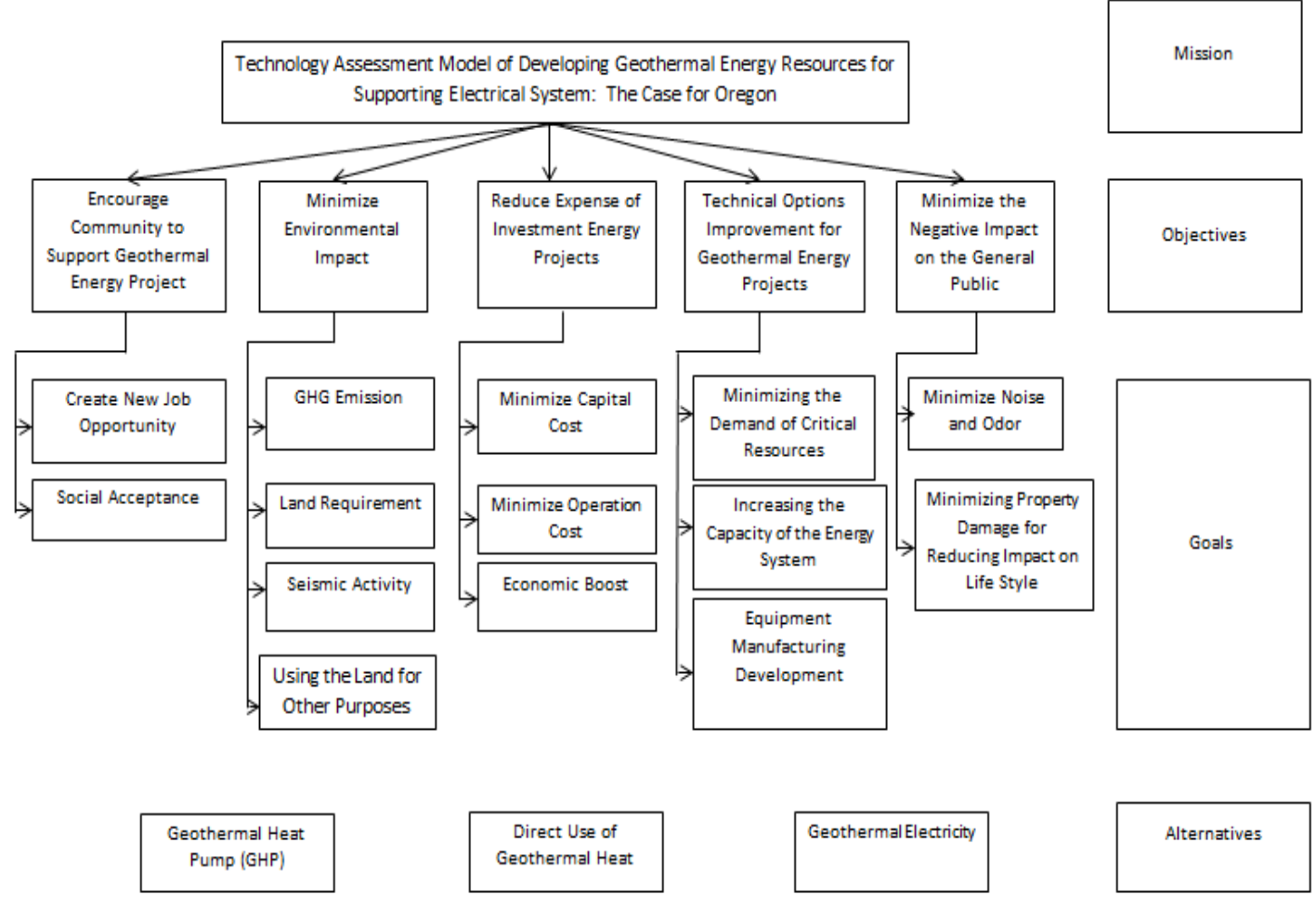

Based on a comprehensive literature review and by validating the proposed research model with my advisor Dr.Tugrul U Daim, this research model will be used for asking experts to establish their weighted output relative to geothermal energy resources. The data collection will be created from this research model to establish the final results of this study.

All the development of the proposed research model will stay in the same frame of the human subject research, and it will not change the HSRRC application. In addition, the goal and objective of the research will be kept from any change. 
The objective of the proposed research is to develop the assessment model framework that can be used for supporting cost-effective renewable energy in Oregon by the development of geothermal energy sources. A mission-oriented model, Hierarchical Decision Making (HDM) will be used to determine the goal that represents the case for Oregon.

HDM is the approach that will be used for analyzing the research objective and criteria used to inform decision about how to inform geothermal energy since HDM works with complicated processes and looks at the problem from different perspectives. All the development occurred to the proposed research model works through criteria, subcriteria, and alternatives and this research model comes from a comprehensive review of literature.

The purpose of the data collection is to ensure the relative importance of decision elements through a numerical quantification process. Using the pairwise comparison method between two elements to evaluate distributional balance is necessary in order to know which element is more important than another. A pairwise comparison will use 100 points scale to make the balance. Defining each element will be clarified below

Encourage Community to Support Geothermal Energy Project: Using geothermal energy project will make future customer life easier and more convenient; the result of using these geothermal energy projects will encourage customers to support geothermal projects. Also, it will increase the adoption and development of geothermal energy.

Minimize Environmental Impact: Using geothermal energy will have a positive impact on the environment since it does not consume a huge amount of fuel.

Reduce Expense of Investment Energy Projects: Different technologies that accompany geothermal energy resources will change the expenses of investment if more attention and effort are given to this area of alternative energy. 
Technical Option Improvement for Geothermal Energy Projects: There is a possibility to develop the process in the future by quickly responding to any changes in the market and in the requirements of customers.

Minimize the Negative Impact on the General Public: Reducing the negative impact on the general public and public spaces ensures that these geothermal projects do not interact with other projects in the same area.

Create New Job Opportunity: When geothermal energy resources are constructed, this construction will require a diversity of skills to complete.

Social Acceptance: The continued commitment to expand and improve federal lands for the use of geothermal resources will lead to an increase in production.

GHG Emissions: Due to lower GHG emissions, geothermal energy projects have less impact on the environment compared with other sources of energy.

Land Requirement: Geothermal fields require fewer acres compared with other sources of energy.

Seismic Activity: While the extraction of geothermal energy can lead to seismic activity, this event would most likely be less than magnitude 2.5 on the Richter scale (earthquakes usually cannot be felt under 3.5).

Using the Land for Other Purposes: When the activity of a power plant is completed, the land can be rehabilitated and used for livestock grazing or other agriculture purposes.

Minimize the Capital Cost: Projects of geothermal energy resources have the potential to reduce the cost of investments if the investments are made over a long period.

Minimize Operation Cost: Geothermal projects can increase the energy production and reduce the cost. 
Economy Boost: "Geothermal projects have the potential to enhance the economies through increased tax revenues, the creation of new businesses and local jobs, and enhanced community involvement" [1].

Minimizing the Demand of Critical Resources: Geothermal projects reduce the demand on traditional resources like oil, coal, and natural gas.

Increasing the Capacity of the Energy System: Using geothermal energy resources will minimize the load on the electrical system and will simplify the challenges associated with increased energy load.

Equipment Manufacturing Development: In spite of the variety of geothermal energy equipment in the market, this equipment still needs more development to increase the geothermal energy efficiency, and for that technologies will need to be developed to use in the manufacturing of this equipment.

Minimize Noise and Odor: It is important for geothermal energy projects to work without negatively impacting the general public by avoiding and reducing noise and odor as quickly as possible.

Minimizing Property Damage for Reducing Impact on Life Style: It is important for geothermal energy projects to minimize the routes to and from the site to avoid any conflicts or obstacles to the movement of residential and commercial activities.

Geothermal Heat Pump: "Is a central heating and/or cooling system that transfers heat to or from the ground. Geothermal heat pumps use the natural insulating properties of the earth from just a few feet underground to as much as several hundred feet deep, offering a unique and highly efficient renewable energy technology for heating and cooling"[2].

Direct use of Geothermal Heat: "refers to the immediate use of the energy for both heating and cooling applications. It is the use of underground hot water to heat buildings, ... and for many other applications. District heating applications use networks of piped hot water to heat buildings in whole communities" [3]. 
Geothermal Electricity: "Geothermal power plants use steam produced from reservoirs of hot water found a few miles or more below the Earth's surface to produce electricity. The extremely high temperatures in the deeper geothermal reservoirs are used for the generation of electricity. The steam rotates a turbine that activates a generator, which produces electricity" [4].

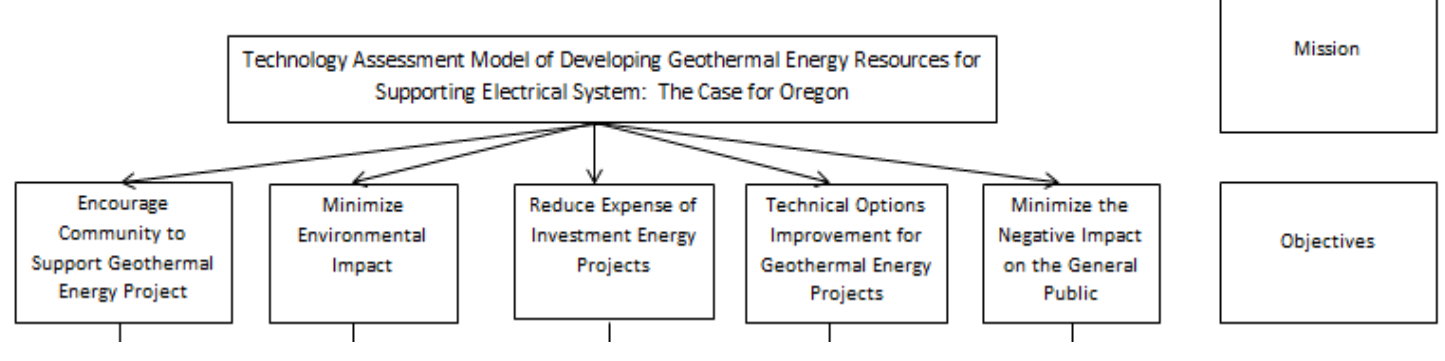

To assess Geothermal Energy Resources for Supporting Electrical System.

The mission of this model is to assess Geothermal Energy Resources for Supporting the Electrical System. This process will require weighting objectives, criteria, and alternatives. A pairwise comparison is required for this purpose to rate criteria (objectives) with respect to each other. As the model is built based on HDM, "a pairwise comparison helps you work out the importance of a number of options relative to one another. This makes it easy to choose the most important problem to solve, or to pick the solution that will be most effective. It also helps you set priorities where there are conflicting demands on your resources. The tool is particularly useful when you don't have objective data to use to make your decision" [5]. This process for Technology Assessment Model of developing geothermal energy resources requires having a scale with 100 points distributed between these main criteria. The criteria with high points result from experts choosing this criterion while the criteria with low points result from few experts choosing this criterion. Also, the score of 0 will not be valid and the score for this situation must be at least 1 point.

This is an example of how to weight, evaluate, and compare: 
Considering two objectives, "Objective A" and "Objective "B", choose the point value that you think is necessary. Since the system is based on 100 points, this can be weighted as $\mathrm{A}=55$ and $\mathrm{B}=45$.

1.1100 points must be distributed between the following pairs of geothermal energy objectives to reflect your judgment on their relative importance to the overall goal for this study.

The importance of encouraging community to support geothermal energy to minimize the environment impact.

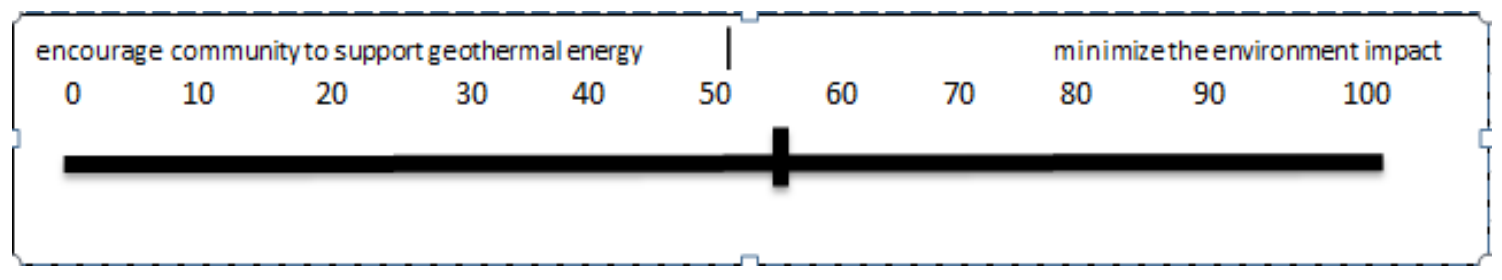

1.2100 points must be distributed between the following pairs of geothermal energy objectives to reflect your judgment on their relative importance to the overall goal for this study.

The importance of encouraging community to support geothermal energy to reduce expense of investment energy project.

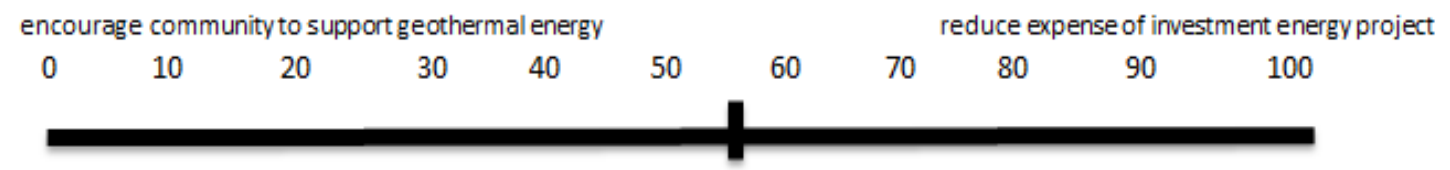

1.3100 points must be distributed between the following pairs of geothermal energy objectives to reflect your judgment on their relative importance to the overall goal for this study.

The importance of encouraging community to support geothermal energy to technical option improvement for geothermal energy project. 


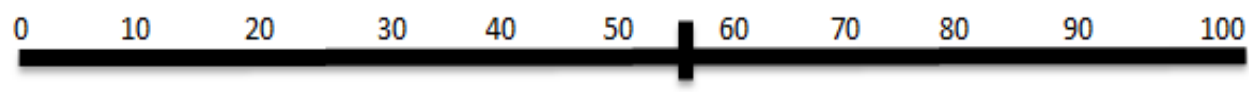

1.4100 points must be distributed between the following pairs of geothermal energy objectives to reflect your judgment on their relative importance to the overall goal for this study.

The importance of encouraging community to support geothermal energy to minimize the negative impact on general public.

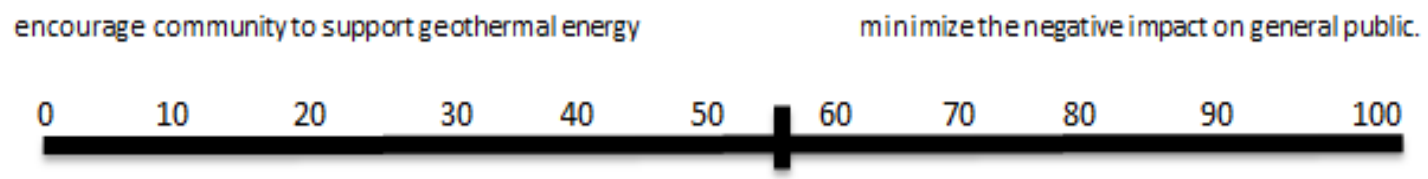

1.5100 points must be distributed between the following pairs of geothermal energy objectives to reflect your judgment on their relative importance to the overall goal for this study.

The importance of minimizing the environment impact to reduce expense of investment energy project.

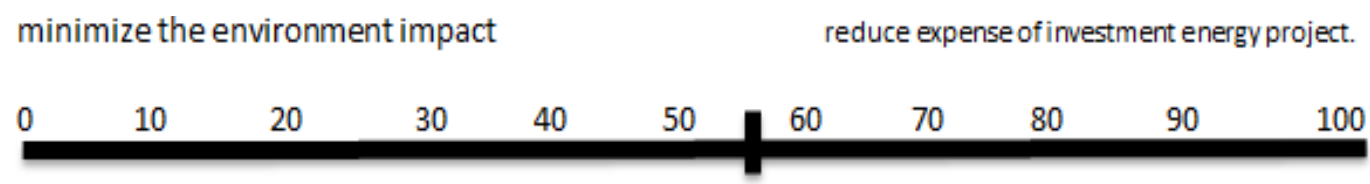

1.6100 points must be distributed between the following pairs of geothermal energy objectives to reflect your judgment on their relative importance to the overall goal for this study.

The importance of minimizing the environment impact to technical option improvement for geothermal energy project. 


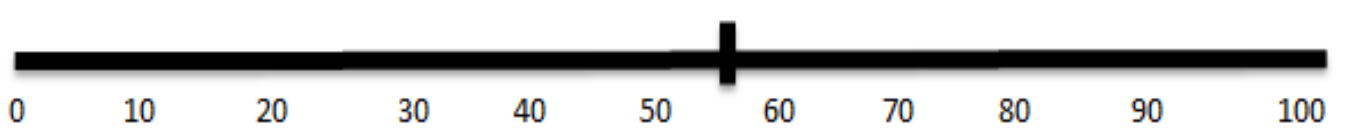

1.7100 points must be distributed between the following pairs of geothermal energy objectives to reflect your judgment on their relative importance to the overall goal for this study.

The importance of minimizing the environment impact to minimize the negative impact on general public.

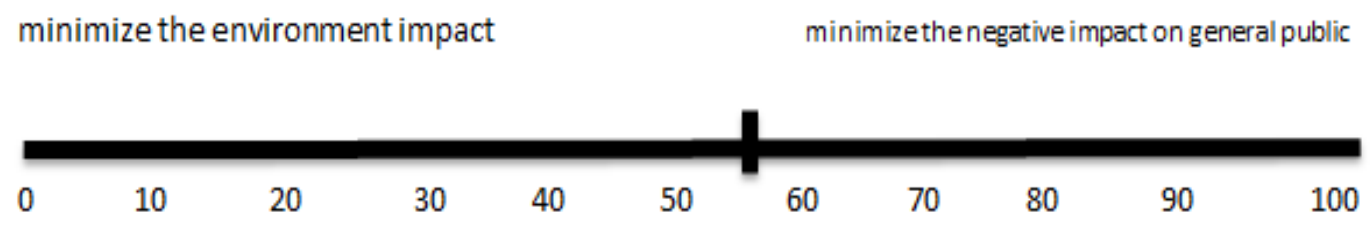

1.8100 points must be distributed between the following pairs of geothermal energy objectives to reflect your judgment on their relative importance to the overall goal for this study.

The importance of reducing expense of investment energy project to technical option improvement for geothermal energy project.

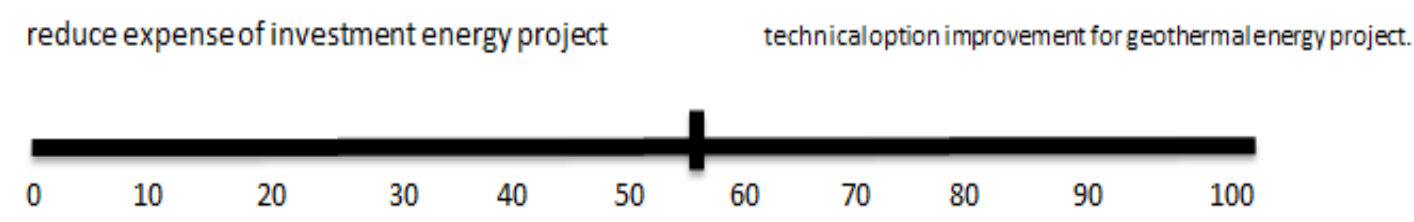

1.9100 points must be distributed between the following pairs of geothermal energy objectives to reflect your judgment on their relative importance to the overall goal for this study.

The importance of reducing expense of investment energy project to minimize the negative impact on general public. 


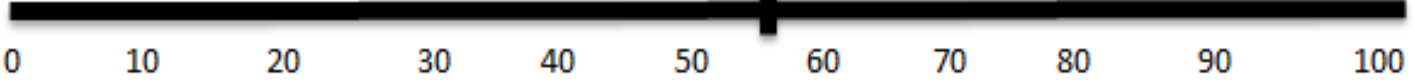

1.10100 points must be distributed between the following pairs of geothermal energy objectives to reflect your judgment on their relative importance to the overall goal for this study.

The importance of technical option improvement for geothermal energy project to minimize the negative impact on general public.

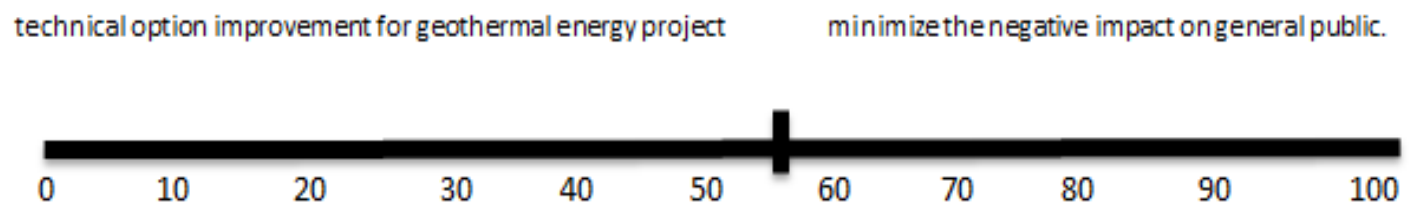


Reference:

[1] G. Council, "What is Geothermal? - Geothermal Resources Council", Geothermal.org, 2017. [Online]. Available: https://geothermal.org/what.html. [Accessed: 19- Jan- 2017].

[2] "Geothermal heat pump", En.wikipedia.org, 2017. [Online]. Available: https://en.wikipedia.org/wiki/Geothermal_heat_pump. [Accessed: 19-Jan- 2017].

[3] Geothermal Today, 1st ed. U.S Department of Energy, 2003.

[4] 2017. [Online]. Available: https://www.nrel.gov/workingwithus/re-geo-elecproduction.html. [Accessed: 19- Jan- 2017].

[5] "Paired Comparison Analysis: Working Out Relative Importances", Mindtools.com, 2017. [Online]. Available: https://www.mindtools.com/pages/article/newTED_02.htm. [Accessed: 19- Jan2017]. 


\section{Appendix B-Judgment Quantifications}

\section{Appendix B1- Judgment quantification for the objectives level with respect to the}

\section{mission.}

The table below shows the ratio of judgment quantification, and explained in the example: CS: 70, IC: 30, and will write CS: IC=70, and 30 will not appear in the table.

Encourage Community to Support Geothermal Energy Projects :CS

Minimize Environmental Impact : EI

Minimize Investment Cost: IC

Technical Options Improvement for Geothermal Energy Projects: TI

Minimize the Negative Impact on the General Public: NI

\begin{tabular}{|c|c|c|c|c|c|c|c|c|c|c|}
\hline & CS:EI & CS:IC & CS:TI & CS:NI & EI:IC & EI:TI & EI:NI & IC:TI & IC:NI & TI:NI \\
\hline $\begin{array}{c}\text { Expert } \\
1\end{array}$ & 50 & 50 & 50 & 50 & 40 & 40 & 60 & 50 & 75 & 75 \\
\hline $\begin{array}{c}\text { Expert } \\
2\end{array}$ & 42 & 42 & 18 & 42 & 46 & 50 & 44 & 35 & 60 & 63 \\
\hline $\begin{array}{c}\text { Expert } \\
3\end{array}$ & 10 & 55 & 75 & 40 & 80 & 75 & 80 & 20 & 20 & 49 \\
\hline $\begin{array}{c}\text { Expert } \\
4\end{array}$ & 18 & 21 & 58 & 50 & 71 & 74 & 86 & 65 & 39 & 60 \\
\hline $\begin{array}{c}\text { Expert } \\
5\end{array}$ & 50 & 50 & 70 & 70 & 20 & 20 & 70 & 50 & 70 & 80 \\
\hline $\begin{array}{c}\text { Expert } \\
6\end{array}$ & 59 & 50 & 32 & 51 & 41 & 62 & 34 & 89 & 52 & 18 \\
\hline $\begin{array}{c}\text { Expert } \\
7\end{array}$ & 70 & 35 & 80 & 45 & 50 & 75 & 35 & 40 & 45 & 20 \\
\hline
\end{tabular}




\section{Appendix B2- Judgment quantification for the goals level with respect to objectives.}

The table below shows the ratio of judgment quantification, and explained in the example: JO: 70, SC: 30 , and will write JO: $\mathrm{SC}=70$, and 30 will not appear in the table.

\section{Encourage Community to Support Geothermal Energy Projects:}

Create New Job Opportunity: JO

Social Acceptance: SC

\begin{tabular}{|c|c|}
\hline & JO:SC \\
\hline Expert 1 & 60 \\
\hline Expert 2 & 40 \\
\hline Expert 3 & 70 \\
\hline Expert 4 & 12 \\
\hline Expert 5 & 90 \\
\hline Expert 6 & 67 \\
\hline Expert 7 & 75 \\
\hline
\end{tabular}

\section{Minimize Environmental Impact:}

GHG Emission: GE

Land Requirement: LR

Seismic Activity: SA

Using the Land for Other Purpose: UL

\begin{tabular}{|c|c|c|c|c|c|c|}
\hline & GE:LR & GE:SA & GE:UL & LR:SA & LR:UL & SA:UL \\
\hline Expert 1 & 50 & 75 & 75 & 75 & 75 & 50 \\
\hline Expert 2 & 72 & 55 & 78 & 50 & 32 & 63 \\
\hline Expert 3 & 99 & 50 & 90 & 10 & 40 & 50 \\
\hline Expert 4 & 70 & 10 & 75 & 10 & 45 & 80 \\
\hline Expert 5 & 50 & 80 & 60 & 89 & 20 & 10 \\
\hline Expert 6 & 43 & 22 & 16 & 29 & 50 & 71 \\
\hline Expert 7 & 5 & 30 & 85 & 15 & 50 & 85 \\
\hline
\end{tabular}




\section{Reduce Expense of Investment Energy Projects:}

Minimize Capital Cost: CC

Minimize Operation Cost: OC

Economic Boost: EB

\begin{tabular}{|c|c|c|c|}
\hline & CC:OC & CC:EB & OC:EB \\
\hline Expert 1 & 50 & 80 & 80 \\
\hline Expert 2 & 58 & 84 & 66 \\
\hline Expert 3 & 70 & 25 & 20 \\
\hline Expert 4 & 80 & 95 & 95 \\
\hline Expert 5 & 95 & 90 & 70 \\
\hline Expert 6 & 50 & 50 & 50 \\
\hline Expert 7 & 65 & 60 & 75 \\
\hline
\end{tabular}

\section{Technical Options Improvement for Geothermal Energy Projects:}

Minimize the Demand of Critical Resources: CR

Increasing the Capacity of Energy System: CS

Equipment Manufacturing Development: ED

\begin{tabular}{|c|c|c|c|}
\hline & CR:CS & CR:ED & CS:ED \\
\hline Expert 1 & 40 & 50 & 60 \\
\hline Expert 2 & 35 & 15 & 31 \\
\hline Expert 3 & 90 & 70 & 20 \\
\hline Expert 4 & 50 & 80 & 95 \\
\hline Expert 5 & 25 & 50 & 70 \\
\hline Expert 6 & 31 & 38 & 66 \\
\hline Expert 7 & 25 & 30 & 25 \\
\hline
\end{tabular}


Minimize the Negative Impact on the General Public:

Minimize Noise and Odor: NO

Minimizing Property Damage for Reducing Impact on Life Style: PD

\begin{tabular}{|c|c|}
\hline & NO:PD \\
\hline Expert 1 & 50 \\
\hline Expert 2 & 66 \\
\hline Expert 3 & 80 \\
\hline Expert 4 & 75 \\
\hline Expert 5 & 99 \\
\hline Expert 6 & 50 \\
\hline Expert 7 & 90 \\
\hline
\end{tabular}




\section{Appendix B3- Judgment quantification for the alternatives level with respect to}

\section{goals}

The table below shows the ratio of judgment quantification, and explained in the example: GE: 70, DH: 30, and will write GE: $\mathrm{DH}=70$, and 30 will not appear in the table.

Geothermal Electricity: GE

Direct Use of Geothermal Heat: DH

Geothermal Heat Pump: GH

Alternatives- Create New Job Opportunity

\begin{tabular}{|c|c|c|c|}
\hline & GH:DH & GH:GE & DH:GE \\
\hline Expert 1 & 60 & 40 & 25 \\
\hline Expert 2 & 29 & 71 & 91 \\
\hline Expert 3 & 65 & 40 & 39 \\
\hline Expert 4 & 65 & 35 & 30 \\
\hline Expert 5 & 90 & 10 & 5 \\
\hline Expert 6 & 50 & 50 & 50 \\
\hline Expert 7 & 20 & 15 & 50 \\
\hline
\end{tabular}

Alternatives-Social Acceptance

\begin{tabular}{|c|c|c|c|}
\hline & GH:DH & GH:GE & DH:GE \\
\hline Expert 1 & 60 & 60 & 50 \\
\hline Expert 2 & 30 & 48 & 77 \\
\hline Expert 3 & 30 & 40 & 56 \\
\hline Expert 4 & 60 & 50 & 20 \\
\hline Expert 5 & 50 & 20 & 10 \\
\hline Expert 6 & 50 & 50 & 50 \\
\hline Expert 7 & 50 & 50 & 50 \\
\hline
\end{tabular}


Alternatives-GHG Emission

\begin{tabular}{|c|c|c|c|}
\hline & GH:DH & GH:GE & DH:GE \\
\hline Expert 1 & 50 & 35 & 35 \\
\hline Expert 2 & 42 & 67 & 68 \\
\hline Expert 3 & 25 & 85 & 70 \\
\hline Expert 4 & 70 & 50 & 30 \\
\hline Expert 5 & 80 & 10 & 1 \\
\hline Expert 6 & 50 & 50 & 50 \\
\hline Expert 7 & 50 & 50 & 50 \\
\hline
\end{tabular}

Alternatives- Land Requirement

\begin{tabular}{|c|c|c|c|}
\hline & GH:DH & GH:GE & DH:GE \\
\hline Expert 1 & 50 & 50 & 50 \\
\hline Expert 2 & 53 & 65 & 51 \\
\hline Expert 3 & 50 & 25 & 40 \\
\hline Expert 4 & 70 & 50 & 70 \\
\hline Expert 5 & 80 & 13 & 5 \\
\hline Expert 6 & 50 & 50 & 50 \\
\hline Expert 7 & 10 & 10 & 10 \\
\hline
\end{tabular}

Alternatives-Seismic Activity

\begin{tabular}{|c|c|c|c|}
\hline & GH:DH & GH:GE & DH:GE \\
\hline Expert 1 & 75 & 90 & 75 \\
\hline Expert 2 & 45 & 62 & 69 \\
\hline Expert 3 & 49 & 50 & 50 \\
\hline Expert 4 & 50 & 50 & 50 \\
\hline Expert 5 & 50 & 50 & 50 \\
\hline Expert 6 & 50 & 50 & 50 \\
\hline Expert 7 & 5 & 5 & 50 \\
\hline
\end{tabular}


Alternatives-Using the Land for Other Purposes

\begin{tabular}{|c|c|c|c|}
\hline & GH:DH & GH:GE & DH:GE \\
\hline Expert 1 & 50 & 50 & 50 \\
\hline Expert 2 & 50 & 35 & 35 \\
\hline Expert 3 & 60 & 70 & 60 \\
\hline Expert 4 & 75 & 50 & 20 \\
\hline Expert 5 & 50 & 20 & 10 \\
\hline Expert 6 & 50 & 50 & 50 \\
\hline Expert 7 & 10 & 5 & 50 \\
\hline
\end{tabular}

Alternatives-Minimize Capital Cost

\begin{tabular}{|c|c|c|c|}
\hline & GH:DH & GH:GE & DH:GE \\
\hline Expert 1 & 40 & 40 & 50 \\
\hline Expert 2 & 22 & 22 & 72 \\
\hline Expert 3 & 60 & 30 & 20 \\
\hline Expert 4 & 40 & 70 & 70 \\
\hline Expert 5 & 50 & 20 & 10 \\
\hline Expert 6 & 50 & 50 & 50 \\
\hline Expert 7 & 30 & 30 & 35 \\
\hline
\end{tabular}

Alternatives- Minimize Operation Cost

\begin{tabular}{|c|c|c|c|}
\hline & GH:DH & GH:GE & DH:GE \\
\hline Expert 1 & 50 & 50 & 50 \\
\hline Expert 2 & 37 & 26 & 54 \\
\hline Expert 3 & 61 & 25 & 20 \\
\hline Expert 4 & 30 & 50 & 60 \\
\hline Expert 5 & 75 & 10 & 5 \\
\hline Expert 6 & 50 & 50 & 50 \\
\hline Expert 7 & 35 & 20 & 30 \\
\hline
\end{tabular}


Alternatives-Economic Boost

\begin{tabular}{|c|c|c|c|}
\hline & GH:DH & GH:GE & DH:GE \\
\hline Expert 1 & 50 & 25 & 25 \\
\hline Expert 2 & 30 & 33 & 64 \\
\hline Expert 3 & 65 & 60 & 60 \\
\hline Expert 4 & 65 & 50 & 30 \\
\hline Expert 5 & 50 & 40 & 30 \\
\hline Expert 6 & 50 & 50 & 50 \\
\hline Expert 7 & 10 & 5 & 40 \\
\hline
\end{tabular}

Alternatives-Minimizing the Demand of Critical Resources

\begin{tabular}{|c|c|c|c|}
\hline & GH:DH & GH:GE & DH:GE \\
\hline Expert 1 & 50 & 50 & 50 \\
\hline Expert 2 & 50 & 67 & 68 \\
\hline Expert 3 & 30 & 60 & 80 \\
\hline Expert 4 & 50 & 15 & 15 \\
\hline Expert 5 & 50 & 40 & 25 \\
\hline Expert 6 & 50 & 50 & 50 \\
\hline Expert 7 & 30 & 30 & 50 \\
\hline
\end{tabular}

Alternatives- Increasing the Capacity of the Energy System

\begin{tabular}{|c|c|c|c|}
\hline & GH:DH & GH:GE & DH:GE \\
\hline Expert 1 & 40 & 20 & 25 \\
\hline Expert 2 & 50 & 63 & 63 \\
\hline Expert 3 & 50 & 30 & 15 \\
\hline Expert 4 & 50 & 30 & 20 \\
\hline Expert 5 & 80 & 1 & 1 \\
\hline Expert 6 & 50 & 50 & 50 \\
\hline Expert 7 & 50 & 50 & 50 \\
\hline
\end{tabular}


Alternatives- Equipment Manufacturing Development

\begin{tabular}{|c|c|c|c|}
\hline & GH:DH & GH:GE & DH:GE \\
\hline Expert 1 & 25 & 10 & 25 \\
\hline Expert 2 & 26 & 28 & 54 \\
\hline Expert 3 & 60 & 40 & 30 \\
\hline Expert 4 & 70 & 50 & 35 \\
\hline Expert 5 & 70 & 30 & 1 \\
\hline Expert 6 & 50 & 50 & 50 \\
\hline Expert 7 & 50 & 5 & 15 \\
\hline
\end{tabular}

Alternatives- Minimize Noise and Odor

\begin{tabular}{|c|c|c|c|}
\hline & GH:DH & GH:GE & DH:GE \\
\hline Expert 1 & 50 & 10 & 10 \\
\hline Expert 2 & 43 & 65 & 76 \\
\hline Expert 3 & 55 & 30 & 30 \\
\hline Expert 4 & 50 & 50 & 50 \\
\hline Expert 5 & 70 & 20 & 11 \\
\hline Expert 6 & 50 & 50 & 50 \\
\hline Expert 7 & 50 & 50 & 50 \\
\hline
\end{tabular}

Alternatives-Minimizing Property Damage for Reducing Impact on Life Style

\begin{tabular}{|c|c|c|c|}
\hline & GH:DH & GH:GE & DH:GE \\
\hline Expert 1 & 25 & 25 & 50 \\
\hline Expert 2 & 50 & 50 & 50 \\
\hline Expert 3 & 50 & 25 & 20 \\
\hline Expert 4 & 50 & 50 & 50 \\
\hline Expert 5 & 50 & 20 & 10 \\
\hline Expert 6 & 50 & 50 & 50 \\
\hline Expert 7 & 30 & 20 & 40 \\
\hline
\end{tabular}




\section{Appendix C- Calculations (Overall weight)}

\begin{tabular}{|c|c|c|c|c|c|c|c|c|c|c|}
\hline \multirow{2}{*}{ Objectives } & & \multicolumn{3}{|l|}{ Gods } & \multicolumn{2}{|c|}{ GHP } & \multicolumn{2}{|c|}{ Diret Heat } & \multicolumn{2}{|c|}{ Geathemal Eleticich } \\
\hline & & & Laral & Gobal & |aral & Goral & Laral & Gotal & lad & Golal \\
\hline \multirow{2}{*}{ 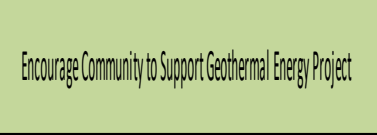 } & \multirow{2}{*}{0.17} & 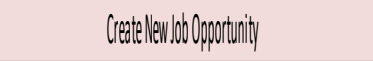 & 0.99 & 0.1 & 0.5 & 005 & 03 & OMA & Qff & 0.05 \\
\hline & & Scrid Aceptariare & OAL & 0.07 & 0.9 & 0.02 & 032 & 002 & 039 & 0.027 \\
\hline \multirow{4}{*}{ 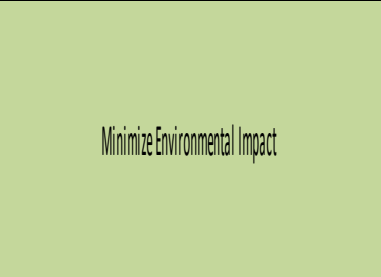 } & \multirow{4}{*}{0.26} & GHGemisision & 03 & 0.078 & 03 & 0023 & 0.3 & 0.03 & OA & 0.3 \\
\hline & & Land Rewivenenth & 0.2 & 0.53 & 0.28 & 0.014 & 0.3 & 0.016 & OAL & 0.2 \\
\hline & & Sesiscichtivity & 0.32 & 0.083 & 0.34 & 0028 & 036 & 0.03 & 03 & 0.024 \\
\hline & & 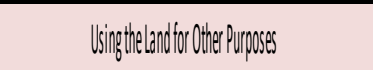 & 0.18 & 0.046 & 0.9 & 0013 & 0.27 & 0.012 & OHA & 0.02 \\
\hline \multirow{3}{*}{ 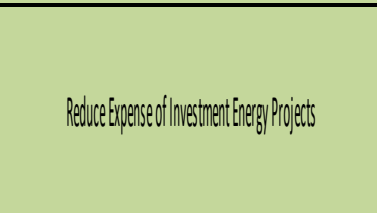 } & \multirow{3}{*}{0.11} & Minmielapid cost & 0.51 & 0.107 & 0.13 & 0.24 & 033 & 0.356 & $\mathrm{OH}$ & 0.097 \\
\hline & & 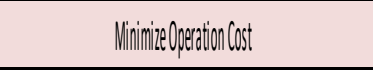 & 0.28 & 0.559 & 0.12 & 0013 & 0.29 & 0008 & OA9 & 0.088 \\
\hline & & Elomonicloost & 021 & 0.044 & 0.27 & 0012 & 0.3 & 0.044 & OKS & 0.018 \\
\hline \multirow{3}{*}{ 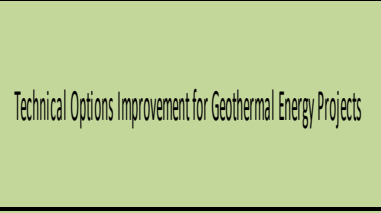 } & \multirow{3}{*}{0.18} & 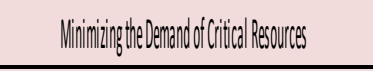 & 0.2 & 0.55 & 0.27 & 0,13 & 0.55 & 0.018 & 038 & 0.099 \\
\hline & & 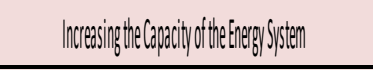 & 039 & 0.07 & 0.24 & 0016 & 0.13 & 0.017 & 0.53 & 0.037 \\
\hline & & 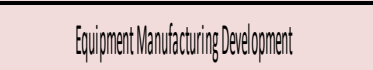 & 033 & 0.06 & 0.212 & 0013 & 0.22 & 0.044 & 056 & 0.033 \\
\hline \multirow{2}{*}{ 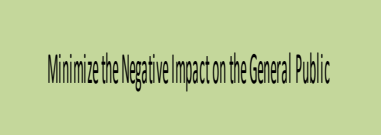 } & \multirow{2}{*}{0.18} & Mriminelloseranclodor & 0.13 & 0.131 & 0.27 & 0.35 & 0.27 & 0.356 & 0.46 & 006 \\
\hline & & 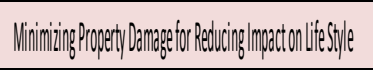 & 0.27 & ONA9 & 0.13 & 0011 & 0.29 & 0.044 & 0.48 & 0.022 \\
\hline & & & & & & 0.66 & & 031 & & D.S \\
\hline
\end{tabular}




\section{Appendix D- Objectives weight for different characteristics of experts}

\section{Objectives weight for different characteristics of experts-Background of Organization}

\begin{tabular}{|c|c|c|c|c|}
\hline Objectives, and goals & Utility & Consulting & $\begin{array}{l}\text { Research } \\
\text { Lab }\end{array}$ & University \\
\hline $\begin{array}{l}\text { Encourage Community to Support } \\
\text { Geothermal Energy Project }\end{array}$ & 0.15 & 0.16 & 0.25 & 0.16 \\
\hline Create New Job Opportunity & 0.43 & 0.65 & 0.9 & 0.67 \\
\hline Social Acceptance & 0.57 & 0.35 & 0.1 & 0.33 \\
\hline Minimize Environmental Impact & 0.28 & 0.34 & 0.12 & 0.16 \\
\hline GHG Emission & 0.23 & 0.5 & 0.31 & 0.1 \\
\hline Land Requirement & 0.2 & 0.2 & 0.23 & 0.18 \\
\hline Seismic Activity & 0.46 & 0.19 & 0.05 & 0.46 \\
\hline Using the Land for Other Purposes & 0.11 & 0.11 & 0.42 & 0.26 \\
\hline $\begin{array}{l}\text { Reduce Expense of Investment Energy } \\
\text { Projects }\end{array}$ & 0.19 & 0.17 & 0.28 & 0.31 \\
\hline Minimize Capital Cost & 0.56 & 0.35 & 0.86 & 0.33 \\
\hline Minimize Operation Cost & 0.33 & 0.29 & 0.08 & 0.33 \\
\hline Economic Boost & 0.11 & 0.36 & 0.06 & 0.33 \\
\hline $\begin{array}{l}\text { Technical Options Improvement for } \\
\text { Geothermal Energy Projects }\end{array}$ & 0.18 & 0.19 & 0.26 & 0.1 \\
\hline $\begin{array}{l}\text { Minimizing the Demand of Critical } \\
\text { Resources }\end{array}$ & 0.21 & 0.47 & 0.21 & 0.2 \\
\hline $\begin{array}{c}\text { Increasing the Capacity of the Energy } \\
\text { System }\end{array}$ & 0.38 & 0.25 & 0.57 & 0.51 \\
\hline Equipment Manufacturing Development & 0.41 & 0.28 & 0.22 & 0.29 \\
\hline $\begin{array}{l}\text { Minimize the Negative Impact on the } \\
\text { General Public }\end{array}$ & 0.2 & 0.14 & 0.08 & 0.27 \\
\hline Minimize Noise and Odor & 0.77 & 0.65 & 0.99 & 0.5 \\
\hline $\begin{array}{l}\text { Minimizing Property Damage for } \\
\text { Reducing Impact on Life Style }\end{array}$ & 0.23 & 0.35 & 0.01 & 0.5 \\
\hline
\end{tabular}




\section{Objectives weight for different characteristics of experts-Background of}

\section{Organization}

\begin{tabular}{|c|c|c|c|c|c|c|c|c|c|c|c|c|c|}
\hline & \multirow[t]{2}{*}{ Alematilies } & \multicolumn{3}{|c|}{ Uilling } & \multicolumn{3}{|c|}{ Consuling } & \multicolumn{3}{|c|}{ Reerachlad lab } & \multicolumn{3}{|c|}{ Uhiersity } \\
\hline & & GP & Direthet & Gool ileth & GP & Diretheat & Geolletet: & GhP & Direthert & Coo bett. & GHP & Directheat & Goo. Elet. \\
\hline \multirow{14}{*}{ colas } & 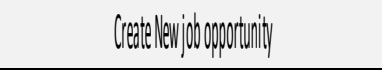 & 0.1 & $D S$ & 0.35 & 0.33 & 0.1 & 0.97 & 0.15 & 0.3 & 0.82 & 0.33 & 0.33 & 0.3 \\
\hline & Sccid hertitare & 031 & 036 & 0.33 & 0.32 & 0375 & 03.15 & 0.14 & 0.11 & 0.15 & 0.33 & 0.33 & 0.33 \\
\hline & GHeminsion & 036 & 0.32 & 031 & 0315 & 0395 & 0.3 & 0.7 & 0.1 .1 & 091 & 0.33 & 033 & 0.33 \\
\hline & Lan Revirienentit & 0.3 & 037 & 033 & 0215 & 03 & DAl & 0.4 & 0.4 & 0.82 & 0.33 & 0.33 & 0.33 \\
\hline & Sessinchativity & 0.13 & on & 034 & 0.51 & 0.855 & 0215 & 0.33 & 0.33 & 0.33 & 0.33 & 0.33 & 0.33 \\
\hline & 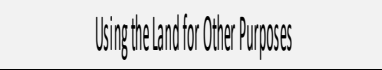 & 0.24 & 0.7 & 0.9 & Q 455 & 032 & 0.27 & 0.4 & 0.11 & 0.15 & 0.33 & 0.33 & 0.33 \\
\hline & Miminecanilal ast & 0.1 & 0.5 & 0.33 & 0.5 & 0.27 & 0.49 & 0.4 & 0.11 & 0.15 & 0.33 & 0.33 & 0.3 \\
\hline & Minimieloperation Cost & 0.19 & 0.37 & OAB & 0275 & 0.24 & 0.48 & 0.11 & ONA & 0.85 & 0.33 & 0.33 & 0.3 \\
\hline & Ecomonicloost & 0.2 & 034 & D. & 0.35 & 0.5 & 046 & 0.8 & 0.4 & 0.48 & 0.33 & 0.33 & 0.33 \\
\hline & 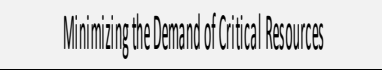 & 0.3 & 0.31 & OH & 0.9 & 0465 & 0.245 & 0.27 & 0.12 & 05.5 & 0.33 & 0.33 & 0.33 \\
\hline & 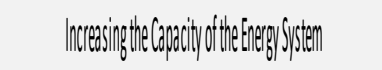 & 0.3. & Q3 & 038 & 0.8 & 0.185 & 0.655 & 0.2 & 0.11 & 098 & 0.33 & 0.33 & 0.33 \\
\hline & 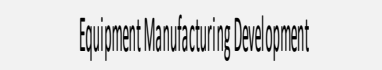 & 0.11 & 0.4 & 0.53 & 0.195 & 0.12 & 0585 & 0.18 & 0.13 & 0.9 & 0.33 & 0.33 & 0.33 \\
\hline & Minimielloserand Codor & 0.33 & 0.38 & 0.27 & 0.17 & 0.155 & 0.68 & 0.19 & 0.9 & 0,12 & 0.33 & 0.33 & 0.33 \\
\hline & 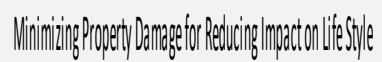 & 0.66 & 0.33 & 0.39 & 0.165 & 0.3 & 0.53 & 0.14 & 0.11 & 0.15 & 0.33 & 0.33 & 0.33 \\
\hline
\end{tabular}




\section{Objectives weight for different characteristics of experts-Position}

\begin{tabular}{|c|c|c|c|c|}
\hline Objectives, and goals & Management & Planning & Policy & Environment \\
\hline $\begin{array}{l}\text { Encourage Community to Support } \\
\text { Geothermal Energy Project }\end{array}$ & 0.18 & 0.135 & 0.25 & 0.13 \\
\hline Create New Job Opportunity & 0.49 & 0.53 & 0.9 & 0.7 \\
\hline Social Acceptance & 0.51 & 0.47 & 0.1 & 0.3 \\
\hline Minimize Environmental Impact & 0.28 & 0.175 & 0.12 & 0.5 \\
\hline GHG Emission & 0.22 & 0.26 & 0.31 & 0.61 \\
\hline Land Requirement & 0.26 & 0.2 & 0.23 & 0.03 \\
\hline Seismic Activity & 0.41 & 0.35 & 0.05 & 0.26 \\
\hline Using the Land for Other Purposes & 0.11 & 0.19 & 0.42 & 0.1 \\
\hline $\begin{array}{l}\text { Reduce Expense of Investment Energy } \\
\text { Projects }\end{array}$ & 0.21 & 0.255 & 0.28 & 0.08 \\
\hline Minimize Capital Cost & 0.53 & 0.44 & 0.86 & 0.25 \\
\hline Minimize Operation Cost & 0.36 & 0.33 & 0.08 & 0.13 \\
\hline Economic Boost & 0.11 & 0.23 & 0.06 & 0.62 \\
\hline $\begin{array}{l}\text { Technical Options Improvement for } \\
\text { Geothermal Energy Projects }\end{array}$ & 0.16 & 0.21 & 0.26 & 0.12 \\
\hline $\begin{array}{l}\text { Minimizing the Demand of Critical } \\
\text { Resources }\end{array}$ & 0.27 & 0.16 & 0.21 & 0.65 \\
\hline $\begin{array}{l}\text { Increasing the Capacity of the Energy } \\
\text { System }\end{array}$ & 0.44 & 0.38 & 0.57 & 0.07 \\
\hline $\begin{array}{c}\text { Equipment Manufacturing } \\
\text { Development }\end{array}$ & 0.29 & 0.46 & 0.22 & 0.28 \\
\hline $\begin{array}{l}\text { Minimize the Negative Impact on the } \\
\text { General Public }\end{array}$ & 0.17 & 0.225 & 0.08 & 0.17 \\
\hline Minimize Noise and Odor & 0.72 & 0.58 & 0.99 & 0.8 \\
\hline $\begin{array}{l}\text { Minimizing Property Damage for } \\
\text { Reducing Impact on Life Style }\end{array}$ & 0.28 & 0.42 & 0.01 & 0.2 \\
\hline
\end{tabular}




\section{Objectives weight for different characteristics of experts- Position}

\begin{tabular}{|c|c|c|c|c|c|c|c|c|c|c|c|c|c|}
\hline & \multirow[t]{2}{*}{ Altematives } & \multicolumn{3}{|c|}{ Nanagenentit } & \multicolumn{3}{|c|}{ Plaming } & \multicolumn{3}{|c|}{ Policy } & \multicolumn{3}{|c|}{ Eniroment } \\
\hline & & GHP & Directheal & Geo, Elect. & GHP & Directheat & Geo: Elect. & GHP & Direthee & Geo, Elect. & GHP & Directhleat & Geo Elect. \\
\hline \multirow{14}{*}{ Goals } & Createl New jobopopontunity & 0.23 & 0.27 & 0.49 & 0.28 & 0.505 & 0.205 & 0.15 & 0.03 & 0.82 & 0.35 & 0.23 & 0.43 \\
\hline & Scria Aceptatance & 0.37 & 0.26 & 0.36 & 0.275 & 0.555 & 0.65 & 0.14 & 0.11 & 0.75 & 0.11 & 0.46 & 0.34 \\
\hline & GHGEmission & 0,33 & 0.25 & 0.4 & 0345 & 039 & 0.26 & 0.07 & 0.01 & 0.91 & 0.35 & 0.53 & 0.12 \\
\hline & Land Requirement & 0.27 & 0.37 & 0.35 & 0.375 & 0.325 & 0.295 & 0.14 & 0.04 & 0.82 & 0.212 & 0.27 & 0.51 \\
\hline & Seismichtivity & 0,35 & 0.35 & 0.3 & 0.34 & 0.385 & 0.27 & 0.33 & 0.33 & 0.33 & 0.33 & 0.34 & 0.33 \\
\hline & Using the landfor Other Purposss & 0.66 & 0.29 & 0.44 & 0.295 & 0.295 & 0.405 & 0.14 & 0.11 & 0.75 & 0.48 & 0.31 & 0.11 \\
\hline & Minimire Capital Cost & 0.66 & 039 & 0.35 & 0.225 & 0.45 & 0.32 & 0.14 & 0.11 & 0.75 & 0.25 & 0.16 & 0.6 \\
\hline & Minimize Operation Cost & 0.23 & 0.35 & 0.4 & 0.26 & 036 & 0,375 & 0.11 & 0.04 & 0.85 & 0.22 & 0.15 & 0.63 \\
\hline & Economic Boost & 0.11 & 0.25 & 0.54 & 0.255 & 0.41 & 0.325 & 0.28 & 0.24 & 0.48 & 0.5 & 0.3 & 0.25 \\
\hline & Ninimizing the Demando of Critical Resources & 0.11 & 0.29 & 0.49 & 0365 & 0.37 & 0.26 & 0.27 & 0.22 & 0.51 & 0.5 & 0.6 & 0.16 \\
\hline & Increasing ghe Capacityothe Energy System & 0.23 & 0.24 & 0.52 & 0.36 & 0.36 & 0.28 & 0.02 & 0.01 & 0.98 & 0.1 & 0.15 & 0.64 \\
\hline & 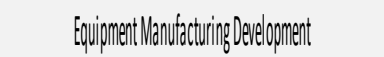 & 0.19 & 0.17 & 0.63 & 0.245 & 0.39 & 0.36 & 0.18 & 0.03 & 0.79 & 0.31 & 0.21 & 0.48 \\
\hline & Ninimize losseandOdor & 0.25 & 0.25 & 0.49 & 0,335 & 0.11 & 0.25 & 0.19 & 0.09 & 0.72 & 0.25 & 0.22 & 0.54 \\
\hline & 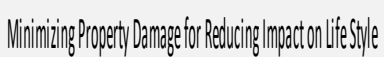 & 0.2 & 0.36 & 0.43 & 0,33 & 033 & 0.33 & 0.14 & 0.11 & 0.75 & 0.19 & 0.17 & 0.63 \\
\hline
\end{tabular}




\section{Objectives weight for different characteristics of experts-Education}

\begin{tabular}{|c|c|c|c|}
\hline Objectives, and goals & $\begin{array}{c}\text { Bachelor } \\
\text { Degree }\end{array}$ & $\begin{array}{l}\text { Master } \\
\text { Degree }\end{array}$ & $\begin{array}{l}\text { Ph.D. } \\
\text { Degree }\end{array}$ \\
\hline $\begin{array}{c}\text { Encourage Community to Support Geothermal } \\
\text { Energy Project }\end{array}$ & 0.1 & 0.17 & 0.21 \\
\hline Create New job opportunity & 0.12 & 0.61 & 0.78 \\
\hline Social Acceptance & 0.88 & 0.39 & 0.22 \\
\hline Minimize Environmental Impact & 0.47 & 0.26 & 0.14 \\
\hline GHG Emission & 0.15 & 0.38 & 0.2 \\
\hline Land Requirement & 0.07 & 0.23 & 0.2 \\
\hline Seismic Activity & 0.68 & 0.27 & 0.26 \\
\hline Using the Land for Other Purposes & 0.09 & 0.12 & 0.34 \\
\hline Reduce Expense of Investment Energy Projects & 0.18 & 0.18 & 0.3 \\
\hline Minimize Capital Cost & 0.7 & 0.42 & 0.6 \\
\hline Minimize Operation Cost & 0.28 & 0.32 & 0.21 \\
\hline Economic Boost & 0.02 & 0.26 & 0.19 \\
\hline $\begin{array}{c}\text { Technical Options Improvement for Geothermal } \\
\text { Energy Projects }\end{array}$ & 0.12 & 0.2 & 0.18 \\
\hline Minimizing the Demand of Critical Resources & 0.36 & 0.3 & 0.2 \\
\hline Increasing the Capacity of the Energy System & 0.59 & 0.26 & 0.54 \\
\hline Equipment Manufacturing Development & 0.05 & 0.44 & 0.26 \\
\hline $\begin{array}{l}\text { Minimize the Negative Impact on the General } \\
\text { Public }\end{array}$ & 0.12 & 0.19 & 0.17 \\
\hline Minimize Noise and Odor & 0.75 & 0.72 & 0.75 \\
\hline $\begin{array}{c}\text { Minimizing Property Damage for Reducing Impact } \\
\text { on Life Style }\end{array}$ & 0.25 & 0.28 & 0.25 \\
\hline
\end{tabular}




\section{Objectives weight for different characteristics of experts-Education}

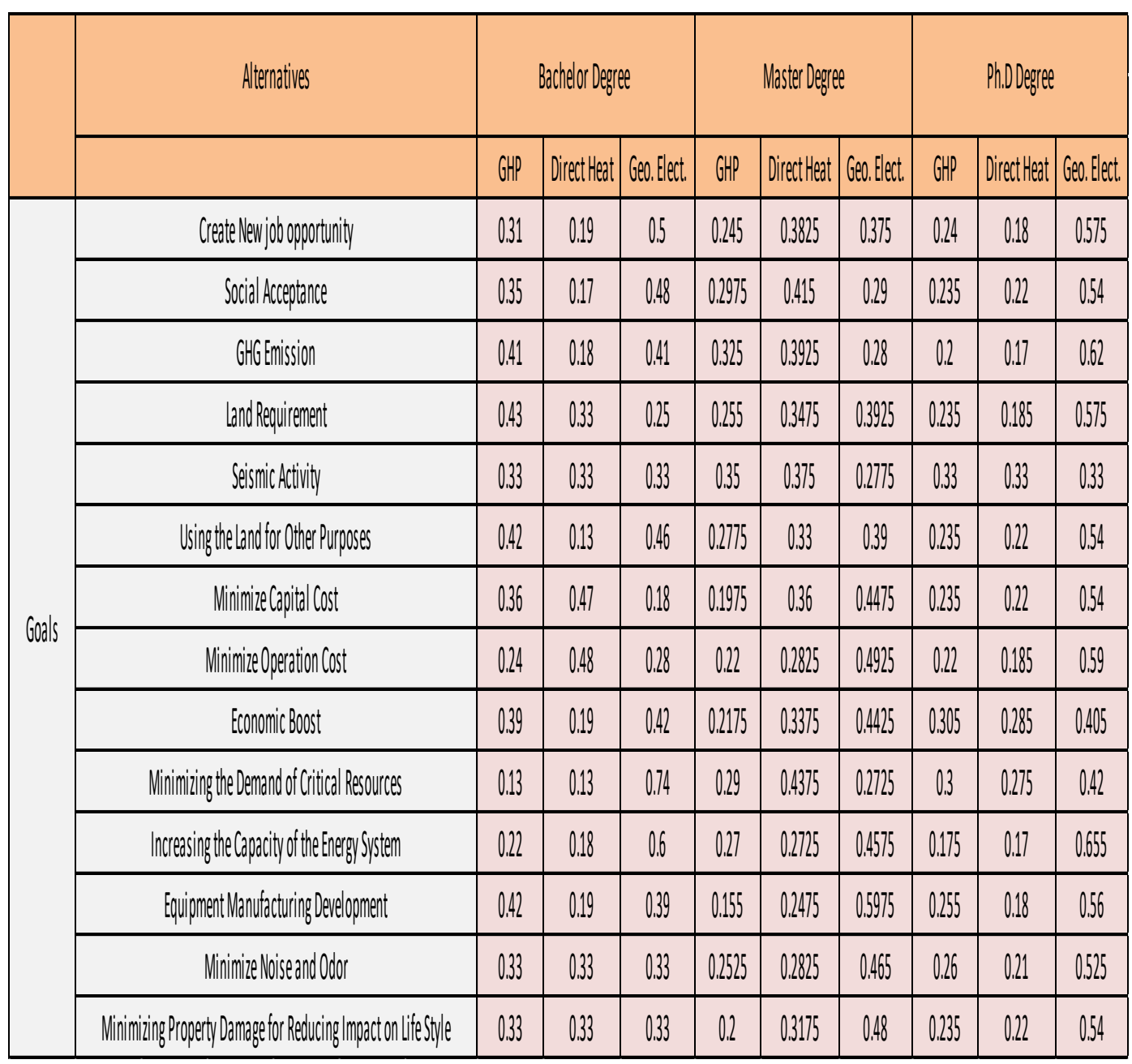

